\author{
Universidade de São Paulo \\ Faculdade de Filosofia, Letras e Ciências Humanas \\ Departamento de Ciência Política
}

MARCELO FRANCISCO DIAS

\title{
Do estruturalismo da Cepal à teoria da dependência: continuidades e rupturas no estudo do desenvolvimento periférico
}

(versão corrigida)

São Paulo

2012 


\section{Universidade de São Paulo \\ Faculdade de Filosofia, Letras e Ciências Humanas \\ Departamento de Ciência Política}

\section{Do estruturalismo da Cepal à teoria da dependência: continuidades e rupturas no estudo do desenvolvimento periférico}

\section{MARCELO FRANCISCO DIAS}

Dissertação apresentada ao Departamento de Ciência Política da Faculdade de Filosofia, Letras e Ciências Humanas da Universidade de São Paulo, para a obtenção do título de Mestre em Ciência Política

ORIENTADORA: PROFA. DRA. ROSSANA ROCHA REIS

Versão corrigida

De acordo:

Professora Dra. Rossana Rocha Reis

São Paulo

2012 
À memória de meu pai, Sidinei Francisco Dias

À memória de Gildo Marçal Brandão, grande mestre das ciências sociais brasileiras 


\section{Agradecimentos}

Muitas são as dificuldades e percalços que se apresentam na realização de toda e qualquer dissertação de mestrado, e esta não poderia ser diferente. Antes mesmo de iniciar propriamente a pesquisa, isto é, na fase de elaboração da proposta de trabalho e preparação para os exames de seleção do programa de pós-graduação, viria a sofrer a perda de meu pai, após sua longa e penosa luta contra o enfisema pulmonar. Não bastasse isso, pouco tempo depois, seria a vez de meu orientador, o saudoso professor Gildo Marçal Brandão, perder a aguerrida batalha contra os problemas cardíacos que lhe acometeram por toda a vida, deixando órfãos todos os que o conheciam. Não teria sido possível ter "superado” essas perdas e seguido adiante na realização deste trabalho, não fosse o apoio direto ou indireto de inúmeras pessoas, algumas das quais gostaria de agradecer neste curto espaço (e já me desculpando àqueles que, por falta de espaço, não poderei aqui mencionar).

Em primeiro lugar, gostaria de agradecer à minha família: minha mãe, Joanira, meus irmãos, Reinaldo e Fábio, e minha irmã, Adriana, pelo carinho de sempre e pelo amparo nos momentos mais difíceis. Gostaria de agradecer também a todos os meus queridos amigos, pela camaradagem, pelo apoio incondicional e por terem tornado essa empreitada mais fácil. À Danúbia, gostaria de agradecer ainda pela dedicação, paciência e ternura que têm tido ao meu lado nos últimos anos.

Agradecimento muito especial gostaria de registrar à professora Rossana Rocha Reis, a quem se pôs, imediata e entusiasmadamente, a penosa tarefa de ser minha orientadora, tão logo da triste notícia sobre Gildo. Apesar de não ter participado da etapa de formatação inicial da presente pesquisa, a professora Rossana encampou-a integralmente, além de ter dado inestimáveis contribuições para a mesma. Sua orientação sempre cuidadosa e atenta, e seus comentários e incentivos em todos os momentos da pesquisa, foram verdadeiramente fundamentais para sua realização. Aproveitando o ensejo, gostaria de agradecer também aos professores Bernardo Ricupero e Brasilio Sallum Jr. pelas valiosas críticas e sugestões realizadas durante a 
qualificação. E aos professores Gabriel Cohn e Luiz Carlos Bresser-Pereira pelos comentários em outros momentos da pesquisa.

À Vera Schattan Coelho, gostaria de agradecer pela oportunidade de participar de inúmeras pesquisas de temas correlatos, e pelo apoio intelectual, científico e afetivo que me tem dispensado nestes últimos anos. Muito tem contribuído para meu desenvolvimento profissional o seu convívio pessoal e o seu incansável estímulo. Em seu nome, gostaria de agradecer a todos os amigos do Núcleo de Cidadania e Desenvolvimento, do Centro Brasileiro de Análise e Planejamento - Cebrap.

À CAPES, agradeço a concessão da bolsa de mestrado, e ao Departamento de Ciência Política sou grato pelas condições institucionais e materiais que permitiram a realização deste trabalho.

Last but not least, não poderia deixar de registrar aqui meus agradecimentos ao professor Gildo. Foi ainda durante a graduação, em suas memoráveis aulas, e nas longas conversas que tínhamos, que fui adquirindo o gosto e a coragem de enfrentar o desafio de estudar o tema do desenvolvimento na América Latina. Apesar de sua inesgotável erudição, Gildo era a um mesmo tempo modesto e muito aberto às discussões com seus alunos, mesmo entre aqueles que, como eu, possuíam muito mais dúvidas do que certezas. Sem deixar de exigir o rigor e a probidade no tratamento das idéias, não deixou o professor Gildo de me incentivar e de me dar plena liberdade para a redação de minha pesquisa. Dele, guardo valiosas lições intelectuais e de vida, e a ele dedico este modesto trabalho.

Desnecessário lembrar que os eventuais equívocos e deslizes aqui cometidos são de minha inteira responsabilidade. 


\section{Resumo}

O presente trabalho busca contribuir na discussão do tema do desenvolvimento e subdesenvolvimento da América Latina, a partir de duas das mais importantes elaborações teóricas já feitas sobre o assunto, o estruturalismo da Cepal e a teoria da dependência. Busca-se fazer uma revisão crítica e sistemática sobre o surgimento, a evolução, e os desdobramentos analíticos e normativos dessas duas grandes escolas do pensamento latino-americano. Em especial, visa explorar as continuidades e rupturas teóricas e metodológicas, em primeiro lugar, entre as interpretações estruturalistas e as interpretações da escola da dependência, e em segundo lugar, entre as distintas vertentes desta última. Argumenta-se que, em ambos os casos, o padrão de continuidade é muito mais proeminente do que se supôs no debate inicial ou de que presume boa parte da literatura especializada, tanto em relação às virtudes, isto é, pensar o desenvolvimento periférico de acordo com suas especificidades histórico-estruturais, quanto, sobretudo, em relação às suas insuficiências, vale dizer, a determinação econômica dos fenômenos políticos e sociais.

Palavras-chave: Teorias do Desenvolvimento e do Subdesenvolvimento da América Latina; Estruturalismo da Cepal; Teoria da Dependência 


\begin{abstract}
This study aims to contribute to the discussion on the issue of the Latin America development and underdevelopment, from two of the most important theoretical frameworks ever made on the subject, the Eclac's structuralism and the dependency theory. We seek to perform a critical and systematic review of the emergence, evolution, and the analytical and normative ramifications of these two major schools of Latin American thought. In particular, it's intended to explore the theoretical and methodological continuities and discontinuities, firstly, between the structuralist interpretations and interpretations of the dependency school, and secondly, between the different approaches of the last one. It is argued that, in both cases, the pattern of continuity is much more relevant than it was assumed in the original debate and even by much of the specialized literature, whether concerning its virtues, that is, to think the peripheral development according its historical-structural specificities, and, above all, in relation to its shortcomings, i.e., the economic determination of political and social phenomena.
\end{abstract}

Keywords: Latin American Theories of Development and Underdevelopment; Eclac's Structuralism; Dependency Theory 


\section{SUMÁRIO}

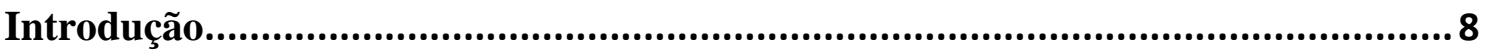

1. O Estruturalismo da Cepal....................................................................... 16

1.1. Raúl Prebisch e o surgimento da escola estruturalista latino-americana........ 16

1.2. Celso Furtado e a historicização do subdesenvolvimento .............................. 32

2. Crise do estruturalismo e emergência da teoria da dependência .......................49

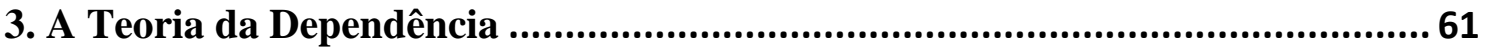

3.1. A Versão Ortodoxa da Dependência ............................................................. 75

3.2. A Versão Heterodoxa da Dependência...................................................... 101

4. A contribuição latino-americana em perspectiva: continuidades e rupturas no estudo do desenvolvimento periférico ............................................. 138

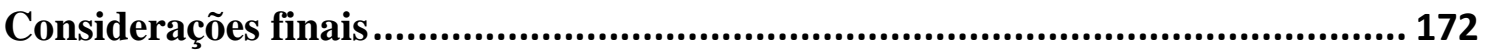

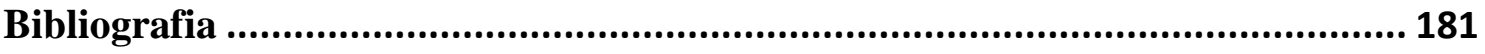




\section{Introdução}

Já faz algum tempo que a questão do desenvolvimento socioeconômico do Brasil e da América Latina vem rendendo debates no mundo acadêmico, político e cultural da região. Antes mesmo de tornar-se a grande coqueluche do pensamento político-social latino-americano, a partir da segunda metade do século vinte até a “crise da dívida”, nos anos oitenta, e muito antes da "redescoberta” contemporânea do assunto, o desafio de promover o desenvolvimento nacional ou regional já foi tema de variados discursos e escritos de políticos, intelectuais, escritores, jornalistas, empresários, diletantes e muitos outros que, preocupados com o crescente descompasso civilizatório entre a IberoAmérica e o "mundo ocidental”, discutiam as causas e propunham possíveis soluções para o encurtamento ou mesmo a eliminação destas distâncias. Assim é que, pelo menos desde as primeiras décadas do século passado, é possível encontrar freqüentes registros em tribunas parlamentares, na imprensa, em obras de caráter literário e, sobretudo, na pena de iminentes cientistas sociais, amplas e por vezes apaixonadas discussões sobre o tema do desenvolvimento da América Latina, em geral, e do Brasil, em particular. Se bem que os termos utilizados à época fossem variantes mais ou menos abrangentes que o da noção de desenvolvimento - conceito popularizado apenas após a Segunda Guerra Mundial -, tais como a idéia do "progresso", da “modernização”, da “formação”, da “integração nacional” etc., o pano de fundo dessas reflexões era quase sempre o mesmo que o do debate das décadas posteriores, qual seja: como fazer da América Latina uma região economicamente mais próspera e socialmente mais justa (e, quando não, culturalmente mais evoluída).

Embora essas formulações tenham resultado em importantes realizações teóricas, e tenham gozado, algumas delas, de razoável prestígio científico e ideológico, elas não chegaram a constituir uma escola própria de pensamento, no sentido mais rigoroso do termo, ou, menos ainda, a terem avançado na direção da construção de uma teoria sobre o desenvolvimento e o subdesenvolvimento de países de formação capitalista tardia. Tais requisitos só seriam preenchidos a partir dos anos cinqüenta, com duas das mais relevantes, e ao mesmo tempo, mais profícuas teorias sociais já produzidas ao sul do Trópico de Câncer, isto é, o estruturalismo da Comissão 
Econômica para a América Latina - Cepal, e a “teoria da dependência” ${ }^{1}$. Durante aproximadamente trinta anos, entre 1950 e 1980, essas escolas de pensamento exerceram um enorme impacto no debate local sobre as causas da pobreza, do atraso econômico e do subdesenvolvimento e, simultaneamente, conseguiriam a proeza de realizar o que poucas matrizes teóricas surgidas na América Latina já fizeram, qual seja, a de repercutir e influenciar muito além dessas terras, conquistando um espaço - ainda que periférico - na galeria de interpretações de influência global.

Desafiando o mainstream do pensamento econômico e social de sua época, que insistia em transpor mecanicamente para o conjunto dos países latino-americanos esquemas de explicação elaborados em função da dinâmica e das necessidades históricas das sociedades centrais, essas teorias produziram um vasto conhecimento teórico, empírico e metodológico que, se não chegaram a constituir novos paradigmas do pensamento, não deixaram de ser originais. A constatação seminal, no começo do período indicado, de que o processo histórico latino-americano era diferente do caminho percorrido no passado pelos países industrializados do Norte, e de que não bastava, portanto, seguir seu receituário “a-histórico” e “universal” para entender o que por aqui se passava, e muito menos, para fundamentar as diretrizes que conduziriam ao desenvolvimento, abriria caminho para toda uma gama de interpretações que, se utilizando de maneira criativa e inovadora conceitos e categorias analíticas vindas das mais distantes paragens, retratariam a América Latina de acordo com suas especificidades históricas e estruturais, de periferia do capitalismo mundial. Com isso, propiciaram um entendimento mais consistente, porque mais afinado com a realidade local, sobre as causas, condições, obstáculos e possibilidades para o desenvolvimento econômico da região. Ao mesmo tempo, fomentariam um amplo debate intelectual que resultaria em alguns consensos e muitas controvérsias, produziria novas teses e volta e meia reproduziria velhas e cansadas fórmulas, geraria seus "ganhadores” e seus "perdedores", ajudaria no desenvolvimento das ciências-sociais latino-americanas e seria “tragada” pela mesma.

\footnotetext{
${ }^{1}$ Conforme já foi propalado inúmeras vezes por seus críticos, e mesmo por alguns de seus "fundadores", não seria possível pensar, rigorosamente, numa "teoria da dependência" (até porque, logicamente, quem depende, depende de algo; tem a sua ação condicionada por outrem, não é o condicionante), sendo mais pertinente, talvez, fazer referência a uma problemática, a um approach, ou a um enfoque da dependência. Entretanto, tendo em vista em ressalva, e levando-se em consideração também que, independente das razões, esta foi a expressão socialmente consagrada no uso corrente das ciências sociais, não faremos o uso das aspas daqui em diante. Voltaremos a este assunto mais à frente.
} 
Ao que chegamos assim ao tema da presente pesquisa. Nosso objetivo mais geral é o de investigar o surgimento, a evolução, as mútuas conexões e os desdobramentos teórico-metodológicos e normativos dessas duas grandes escolas do pensamento latinoamericano. Busca-se, assim, realizar uma reconstituição crítica daquele debate, examinando sua origem e desenvolvimento, confrontando umas idéias com as outras, e procurando explorar as potencialidades e deficiências das principais interpretações. Trata-se, portanto, essencialmente, de um trabalho de história das idéias. Ainda que se examine, sumariamente, as questões "práticas" que envolveram ou ensejaram estas diversas formulações, isto é, a história política e econômica do período, bem como a aplicação de algumas dessas idéias enquanto políticas públicas para o desenvolvimento, o foco analítico principal desta pesquisa reside no exame do pensamento em si mesmo. Neste sentido, a análise do processo histórico daquela época serviu, antes de mais nada, para subsidiar o entendimento da constituição e do desenvolvimento dos diagnósticos e proposições, e não o contrário.

Dentro do macro-objetivo proposto, procuramos explorar alguns pontos que, em nossa avaliação, mereciam um tratamento mais sistemático e/ou mais adequado do que o realizado por boa parte da literatura. Em primeiro lugar, e como um fim em si mesmo, estava a própria finalidade de se realizar uma história intelectual das referidas teorias. Existe uma gama considerável de trabalhos que examinam o estruturalismo e/ou a teoria da dependência, no entanto, não são muitos os que realizam uma investigação sobre o surgimento, auge e declínio dessas análises, que verifiquem o percurso teórico de suas principais correntes e autores, que investiguem suas semelhanças e diferenças, enfim, que ponham as "idéias em movimento"” dependência, a maioria dos trabalhos encontrados realiza não uma história das idéias, e sim uma avaliação crítica das mesmas ${ }^{3}$, não raro com o objetivo velado ou explícito de

\footnotetext{
${ }^{2}$ Dentre estes, dois merecem destaque: KAY, Cristobal. Latin American Theories of Development and Underdevelopment. London: Routledge, 1989; e também LOVE, Joseph. A construção do Terceiro Mundo. São Paulo: Paz e Terra, 1998.

${ }^{3}$ Entre os muitos trabalhos deste tipo, encontram-se: PALMA, Gabriel. "Dependency: A formal theory of underdevelopment or a methodology for the analysis of concrete situations of underdevelopment". World Development, nº, 1978; BRESSER-PEREIRA, Luiz Carlos. "Seis interpretações do Brasil”. Dados, Rio de Janeiro, 25(3), 1982; CHILCOTE, Ronald. Dependency and Marxism: Toward a Resolution of the Debate. London: Westview Press, 1982; GOLDENSTEIN, Lídia. Repensando a dependência. São Paulo: Paz e Terra, 1994; BRESSER-PEREIRA, Luiz Carlos. "Do Iseb e da Cepal à Teoria da Dependência”. In: TOLEDO, Caio Navarro (Org.). Intelectuais e política no Brasil: a experiência do ISEB. São Paulo: Revan, 2005.
} 
demonstrar os limites de tal ou qual vertente teórica ${ }^{4}$. Esses trabalhos de síntese crítica, muito embora necessários, por vezes limitam-se a demonstrar "quem tinha razão" no debate, ou ainda, retratam o pensamento de determinado autor ou corrente de maneira superficial, circunscrita a determinada(s) obra(s), o que os impossibilita, amiúde, de captar a dinâmica do pensamento social em sua plenitude. Há, por outro lado, alguns estudos que realizam uma reconstrução da história do pensamento, pelo menos tal como a entendemos, no entanto, é freqüente entre estes mesmos estudos desconsiderar vertentes inteiras da teoria em questão, tomando a parte como se fosse o todo e, conseqüentemente, retratando de maneira inadequada o debate ${ }^{5}$.

Ainda com relação à teoria da dependência, buscou-se passar em revista algumas das muitas e talvez excessivas distinções feitas sobre as diferentes correntes que se formaram no interior dessa escola. Sem negar a importância dessas várias possibilidades classificatórias, procuramos demonstrar a inadequação de algumas delas, sobretudo, aquelas que dão excessivo destaque ao conteúdo político-normativo intrínseco àquelas idéias, deixando em segundo plano seus caracteres especificamente analíticos e conceituais, o que resulta, freqüentemente, em caracterizações que exageram nas diferenças e mitigam as semelhanças entre as distintas versões da teoria da dependência. Neste sentido, revelou-se que algumas das presumidas diferenças existentes entre elas ou não existiam ou eram muito mais tênues do que se imaginava.

Paralelamente a isto, buscamos avaliar em que medida as análises da escola da dependência foram capazes de superar as limitações de ordem teóricas, metodológicas e ideológicas por elas próprias apontadas em relação às interpretações do estruturalismo cepalino. É relativamente consensual entre os pensadores da supracitada escola e

\footnotetext{
${ }^{4}$ Os trabalhos deste tipo são em sua maioria, e não por acaso, oriundos dos próprios participantes do debate original sobre a dependência. Vide, por exemplo, os muitos trabalhos de Fernando Henrique Cardoso sobre o assunto, como o seu "Notas sobre o estado atual dos estudos sobre a dependência". Cadernos Cebrap, São Paulo, vol. 11, p. 30-72, 1973; ou ainda SERRA, José; CARDOSO, Fernando Henrique. “As Desventuras da Dialética da Dependência”. Estudos CEBRAP, vol. 23, São Paulo, 1979. Da mesma forma, as análises da versão "radical" da dependência sobre o debate, apresentam o mesmo tipo de inclinação. Veja-se, por exemplo, SANTOS, Theotônio dos. A teoria da dependência - Balanço e perspectivas. Rio de Janeiro: Civilização Brasileira, 2000.

${ }^{5}$ Veja-se, por exemplo, o estudo de Guido Mantega, de 1997, no qual o autor, embora objetivasse "reconstituir a crítica da dependência ao modelo econômico brasileiro", relega a um segundo plano todas as análises ligadas à corrente radical da teoria da dependência, as quais, na verdade, considera que não faziam parte da escola dependentista, e sim da corrente neomarxista. Cf. MANTEGA, Guido. Teoria da dependência revisitada: um balanço crítico. São Paulo: FGV-EAESP, 84 p. Relatório de Pesquisa, 1997. Esta mesma limitação pode ser vista em PACKENHAM, Robert. The Dependency Movement: Scholarship and Politics in Development Studies. Cambridge: Harvard University Press, 1992.
} 
também em boa parte da literatura a respeito do tema, a avaliação de que a teoria da dependência representou um importante avanço no estudo do desenvolvimento periférico, no sentido de incorporar na análise aspectos precariamente contemplados na matriz estruturalista, isto é, a dimensão política do subdesenvolvimento e/ou os condicionantes sociais internos que levavam à dependência externa. Assim, a maioria dos comentadores aponta a tentativa de superação do "economicismo" das interpretações estruturalistas como um dos saldos líquidos da teoria da dependência em relação a sua “antecessora” intelectual. Entretanto, esta avaliação refere-se, no mais das vezes, mais aos fundamentos e intenções metodológicas de seus autores do que propriamente a seu conteúdo analítico. Em outras palavras, boa parte da literatura aceita acriticamente a avaliação que os autores dependentistas tinham de si próprios, resumindo-se a indicar, sem efetivamente demonstrar, como suas análises conseguiram, de fato, superar a interpretação estruturalista sobre o processo de desenvolvimento na América Latina. Nosso trabalho tentou evitar assumir esse mesmo "pressuposto" teórico: sempre quando possível, buscou-se verificar se, como, e em que medida, os estudos filiados à teoria da dependência foram capazes de sobrepujar as inconsistências e insuficiências diagnosticadas no pensamento histórico-estrutural da Cepal. Para tanto, empreendemos uma análise relativamente pormenorizada e sistemática dos principais textos de ambas as escolas do pensamento. Ao fazê-lo, chegamos a conclusões bastante distintas ao que apontam muitas das análises realizadas sobre o debate: a despeito de suas pretensões metodológicas, a teoria da dependência, mesmo a sua versão supostamente mais complexa e nuançada, não conseguiu escapar de algumas das deficiências atribuídas ao pensamento estruturalista, em especial, a de considerar os processos políticos e sociais como condicionados ou determinados pelos processos econômicos. Sob este aspecto, concluímos assim que há mais elementos de continuidade entre essas duas escolas de pensamento do que comumente se pressupõe. O que não impediu, evidentemente, dos autores dependentistas terem enxergado com mais nitidez que seus colegas estruturalistas as transformações econômicas e sociais em curso na região, ou de terem contribuído para o amadurecimento das ciências sociais latino-americanas, abrindo novas frentes no estudo do desenvolvimento capitalista em sociedades dependentes.

O presente trabalho é, portanto, uma tentativa de se compreender melhor o debate em torno do estruturalismo latino-americano e da teoria dependência, ainda que 
não tenha a vã pretensão de esgotá-lo. Com efeito, embora toda aquela fértil discussão a respeito do desenvolvimento e da dependência da América Latina tenha virtualmente se "encerrado", por uma série de motivos ${ }^{6}$, há mais de trinta anos atrás, de forma nenhuma terminaram as interpretações e reinterpretações sobre aquele período intelectual, não apenas por aqueles que participaram diretamente dele, mas também por novas e originais leituras. Nesse sentido, o debate continua tão vivo e "presente" quanto antes. Certamente contribui para isso o fato de um dos mais ativos personagens daquele debate, o sociólogo Fernando Henrique Cardoso, ter se tornado presidente do Brasil, o que acabou por trazer muitas daquelas velhas idéias novamente à tona, assim como as polêmicas e "confusões" em torno delas. A esse respeito, aliás, nunca foi mais verdadeira a afirmação de Robert Packenham, de que as idéias da dependência continuam "ampla e seriamente mal-entendidas", e de que "até que as idéias da dependência sejam melhor entendidas, os debates e as tentativas de verificá-las continuarão gerando mais calor do que luz”’ . Não por acaso, já que os temas sobre os quais incidiam aquelas formulações, quais sejam, o desafio do desenvolvimento nacional e democrático, a justiça social, a distribuição da renda e da riqueza, a inserção do Brasil e dos países vizinhos no mercado mundial, entre outros, embora repostos e atualizados, continuam na ordem do dia. Nesse sentido, acreditamos ser sempre possível e até necessário revisitar aquele debate.

Apresentar as principais idéias em torno das supracitadas escolas do pensamento é por si só uma tarefa altamente complexa, não apenas devido à colossal quantidade de livros, artigos e documentos produzidos ininterruptamente por um período de aproximadamente trinta anos, como também devido à própria evolução e sofisticação do debate em si mesmo, às revisões dos argumentos e proposições originais, os distintos pontos de vista sobre esse mesmo debate etc. Assim sendo, como é natural, foi necessário realizarmos algumas escolhas a fim de delimitar o campo de estudo e possibilitar a realização do trabalho. Em primeiro lugar, procurou-se centralizar a análise na “discussão interna” entre o estruturalismo e a teoria da dependência, relegando a um segundo plano as discussões paralelas e correlatas, ou aquelas que, de certa maneira, derivaram dessas discussões. Assim, o presente trabalho tangencia, mas não se aprofunda no debate sobre a questão dos modos de produção, do colonialismo

\footnotetext{
${ }^{6}$ Nas considerações finais, arrolamos algumas das causas responsáveis pelo declínio do debate.

${ }^{7}$ PACKENHAM, Robert., op. cit., p. 3, tradução nossa
} 
interno, do populismo, da marginalidade, do autoritarismo-buruocrático, do sistemamundo, entre outros. Em segundo lugar, e seguindo este mesmo princípio, buscou-se focar na obra e no pensamento dos mais eminentes representantes de cada uma das escolas de pensamento em questão. Não que os autores “secundários” tenham sido desconsiderados, apenas que não se empreendeu em relação às suas obras uma análise sistemática, da mesma maneira que se realizou com a dos autores considerados mais centrais. Desta forma, pensadores que trouxeram contribuições pontuais, ainda que inestimáveis, ao debate, ou que participaram dele apenas "indiretamente", tais como Caio Prado Jr. ou Florestan Fernandes, receberam de nossa parte menos atenção do que aqueles que, de alguma forma, centralizaram as discussões.

Tendo-se em vista os objetivos acima propostos, organizamos o presente trabalho em quatro capítulos principais. No primeiro deles, analisa-se o surgimento e o desenvolvimento da escola estruturalista latino-americana. Para tanto, retratamos, em diferentes subcapítulos, o pensamento de dois de seus mais importantes representantes, o inaugurador da referida escola, o economista argentino Raúl Prebisch, e o seu principal colaborador ou "sucessor", o economista brasileiro Celso Furtado. Nesse capítulo, discute-se a crítica desses autores às teorias clássica e neoclássica do pensamento econômico; a criação do paradigma centro-periferia e a análise dos efeitos desiguais que a divisão internacional do trabalho provocava em cada um desses pólos; a conceituação e periodização do subdesenvolvimento, como um fenômeno históricoestrutural singular, inerente à expansão do sistema capitalista; bem como as propostas formuladas por esses autores, e pela Cepal mais amplamente, para a tentativa de superação da condição periférica. No capítulo seguinte, retrata-se o contexto econômico, político, social e ideológico da virada dos anos cinqüenta para os sessenta de crise do modelo cepalino de industrialização por substituição de importações, por um lado, e de radicalização política, por outro - em que as formulações dos pensadores estruturalistas começavam a perder tanto a capacidade de explicar as transformações econômico-sociais em curso nos países da região, quanto a atração que exerciam no âmbito da esquerda brasileira e latino-americana, já abrindo caminho para novas interpretações sobre o desenvolvimento capitalista dependente da América Latina. No terceiro capítulo, discute-se o surgimento da teoria da dependência, seus antecedentes intelectuais, as "polêmicas” iniciais do debate, as ramificações no interior da escola dependentista, assim como as diversas tipologias encontradas na literatura para 
classificá-las. A partir daí, analisa-se em detalhes, em diferentes seções, suas duas mais importantes correntes, a saber, a vertente ortodoxa e heterodoxa da teoria da dependência. No quarto capítulo, essas mesmas vertentes são postas em confronto umas com as outras, a fim de explorar a consistência de seus diagnóstico e proposições e, sobretudo, investigar como cada qual foi capaz, ou não, de superar o arcabouço analítico da escola estruturalista. Por último, tecemos algumas considerações finais sobre o caminho aqui percorrido. 


\section{O Estruturalismo da Cepal}

\subsection{Raúl Prebisch e o surgimento da escola estruturalista latino-americana}

O surgimento e o desenvolvimento da escola estruturalista latino-americana ${ }^{1}$ relaciona-se diretamente com o contexto geopolítico e econômico internacionais do pós $2^{\text {a }}$. Guerra Mundial. Se até aquele momento o tema do atraso econômico e social das regiões pobres ao redor do globo não chegou a receber grande atenção da ciência econômica ${ }^{2}$ - porque, em realidade, sequer era tido como um problema relevante - ou mesmo por parte das principais potências mundiais, a partir de então esse quadro modificar-se-ia inteiramente. A proliferação de instituições internacionais ${ }^{3}$ e planos econômicos visando a modernização dessas áreas, aí incluídos os diversos países saídos do domínio colonial nos continentes africano e asiático, a Europa Oriental, e naturalmente, a América Latina, é sintomático dessa mudança no cenário político e intelectual da época. Os motivos que explicam esse “súbito” despertar de interesse pelo desenvolvimento dos países atrasados eram tanto de natureza social e humanitária quanto, sobretudo, de natureza política ${ }^{4}$ :

The war had changed the balance of world power. The former colonial powers emerged greatly weakened, the national independence movements greatly strengthened. The ascendancy of the Soviet Union and the consequent spread of communism influence gave the less developed countries the status of a Third World progressively able to take advantage of the Cold War between

\footnotetext{
${ }^{1}$ A exposição feita aqui contempla apenas a fase mais criativa e original da escola estruturalista da Cepal, isto é, o período compreendido entre os anos 1950 e 1960. Para uma exposição sobre o pensamento da referida escola nos decênios seguintes veja-se BIELSCHOWSKY, Ricardo. "Cincuenta años del pensamiento de la Cepal: una reseña”. In: CEPAL. Cincuenta años de pensamiento en la Cepal - Textos Seleccionados. Volumen I. Santiago: Fundo de Cultura Económica, 1998, p. 9-62.

2 "The classical economists, from Adam Smith to J.S. Mill and Marx, were intensely interested in economic development But their concern was naturally with the capitalist development of their own western world”. ARNDT, H.W. Economic Development: The History of an Idea. Chicago: Chicago University Press, 1987, p.30.

${ }^{3}$ Entre as principais instituições criadas destacam-se, no âmbito da recém-criada Organização das Nações Unidas, cinco organizações voltadas para promover o desenvolvimento econômico regional, entre elas a Comissão Econômica para a América Latina - Cepal, de longe a mais importante delas.

${ }^{4}$ Não apenas no cenário internacional o desenvolvimento passou a ser um objetivo primordial a ser alcançado por meio de políticas econômicas e sociais; no próprio contexto doméstico dos países em desenvolvimento, essa passou a ser uma meta de primeira ordem. Duas guerras mundiais, a maior crise econômica que o capitalismo experimentara até então, os processos de descolonização das antigas colônias, a queda do preço dos produtos de exportação primária etc., tudo isso alterava a balança de poder no interior desses países, em favor de grupos sociais e econômicos (burguesia industrial, operariado, setores médio-urbanos etc.) diretamente interessados na promoção do desenvolvimento e da industrialização.
} 
the superpowers to press their demands. In the West, the exigencies of power were reinforced by the commitment of influential public opinion to liberal and humanitarian principles which found colonial rules and the glaring contrast between life in rich and poor countries no longer acceptable. ${ }^{5}$

Se pouco após o termino da $2^{\mathrm{a}}$. Guerra Mundial as discussões sobre o desenvolvimento econômico do Terceiro Mundo restringiam-se, basicamente, às agências da ONU e a algumas outras poucas organizações internacionais, em pouco tempo uma vasta literatura especializada no assunto despontaria no campo do pensamento econômico, ajudada, em parte, pelo crescente volume de informações e estatísticas nacionais produzidas ou organizadas por esses organismos. Motivadas por um certo sentido de urgência em relação ao clamoroso atraso das economias subdesenvolvidas e influenciadas, boa parte delas, pela "revolução keynesiana”, essas novas interpretações passariam a questionar a eficácia de muitas das prescrições ditadas pelo pensamento econômico tradicional, que, de acordo com elas, havia sido impotente para lidar com as crises cíclicas do capitalismo ou com a crescente disparidade do nível de renda entre países ricos e países pobres. Assim, durante toda a década de 1950, na esteira da crise do laissez-faire, entraria em cena um amplo conjunto de teorias econômicas pregando um papel mais ativo do Estado na promoção do bem estar social e na busca do desenvolvimento, tido, naquele momento, como sinônimo de crescimento econômico e, especialmente na América Latina, como sinônimo de industrialização. Desta forma, surgiria uma extensa e diversificada série de esquemas teóricos, modelos de interpretação econômica e proposições desenvolvimentistas, tais como a do big push $^{6}$, a da decolagem ou take-off ${ }^{7}$, a do crescimento equilibrado ${ }^{8}$, a do crescimento desequilibrado ${ }^{9}$, o "modelo de Lewis" 10 , e diversos outros, que ajudariam a formar o quadro analítico-conceitual do que se convencionou denominar de economia do desenvolvimento.

\footnotetext{
${ }^{5}$ ARNDT, H.W., op. cit, p. 49-50.

6 ROSENTEIN-RODAN, Paul Narcyz. "Problemas da Industrialização da Europa Oriental e SulOriental”. In: AGARWALA, A.N.; SINGH, S.P. (Orgs.) A economia do subdesenvolvimento. Rio de Janeiro: Forense, 1969, p. 251-262.

${ }^{7}$ ROSTOW, Walt Whitman. “A decolagem para o desenvolvimento auto-sustentado”. In: AGARWALA, A.N.; SINGH, S.P. (Orgs.), op. cit., p. 159-193.

${ }^{8}$ NURSKE, Ragnar. Problemas da formação de capital em países subdesenvolvidos. Rio de Janeiro: Civilização Brasileira, 1957.

${ }^{9}$ HIRSCHMAN, Albert O. Estratégia do desenvolvimento econômico. Rio de Janeiro: Fundo de Cultura, 1961.

${ }^{10}$ LEWIS, William Arthur. “O desenvolvimento econômico com oferta ilimitada de mão-de-obra”. In: AGARWALA, A.N.; SINGH, S.P. (Orgs.), op. cit., p. 406-456.
} 
Coetânea à nova disciplina que se estabelecia no campo do pensamento econômico mundial, a Comissão Econômica para a América Latina, doravante Cepal, não apenas contribuiria para sua evolução e popularização, como seria, ela própria, artífice de um original modelo analítico para o exame de problemas econômicos e sociais de países de desenvolvimento capitalista retardatário, qual seja, o método histórico-estrutural de análise, ou simplesmente, estruturalismo. Não foi, entretanto, por mero capricho intelectual que os pesquisadores da agência da ONU para a América Latina chegaram a constituir uma escola própria de pensamento, ao contrário, seu surgimento se deu, em boa medida, por razões práticas. Ao procurar entender e equacionar as graves distorções macro-econômicas que assolavam os países da região, os autores cepalinos se depararam com os limites teóricos e metodológicos da ciência econômica convencional: com seu falso sentido de universalidade, abstrata, a-histórica, e além do mais, moldada no contexto econômico e social dos países ricos e industrializados. Em outras palavras, as análises consagradas pelo mainstream do pensamento econômico daquele período, isto é, aquelas filiadas às teorias clássica e neoclássica, defendiam que era possível compreender a estrutura e o modo de funcionamento das economias dos países em desenvolvimento, bem como propor soluções para seus problemas, tendo-se como base os mesmos instrumentais e premissas teóricas que as utilizadas para interpretar a economia dos países avançados, desconsiderando, assim, as diferenças existentes entre ambas, que, conforme bem exemplifica Cristóbal Kay, eram nítidas e ocorriam por toda parte:

In many Third World countries, for example, money was not an universal means of exchange and financial institutions hardly existed, a large proportion of the rural population were subsistence peasant farmers, infrastructure (such as roads, communications, and energy) was limited, education and literacy poor, and so on. This meant that capital and labour markets as well as price mechanism worked very differently in these countries compared with their equivalents in the industrial nations. ${ }^{11}$

A maneira com que esses economistas de orientação neoclássica lidavam com os problemas econômicos latino-americanos era análoga, assim, à atitude descrita pelo economista chileno Osvaldo Sunkel: se a teoria não correspondia à realidade, pior para a realidade, que deveria ser modificada a fim de corresponder às suas premissas

\footnotetext{
${ }^{11}$ KAY, Cristóbal, op. cit., p.3.
} 
teóricas $^{12}$. Bastaria, portanto, aos países atrasados aplicar as mesmas políticas econômicas liberais que as nações desenvolvidas supostamente ${ }^{13}$ haviam se utilizado em seu processo histórico, para aqueles atingirem o mesmo estágio de desenvolvimento em que estes últimos se encontravam ${ }^{14}$.

Para os autores cepalinos, esses pressupostos não apenas eram incapazes de explicar as graves e crônicas dificuldades econômico-sociais da América Latina (o estrangulamento externo, os constantes déficits fiscais, a super inflação, os elevados índices de desemprego etc.), como, na medida em que constituíam o substrato teórico do receituário ortodoxo-liberal historicamente adotado pelos governos da região, representavam mesmo umas das principais causas dessas dificuldades. Para examinar e propor soluções para os impasses do capitalismo periférico, defendiam esses autores, não bastava importar a teoria econômica gestada nas nações desenvolvidas - ainda que fosse de fundamental importância conhecê-las - era preciso um esforço de teorização autônomo que, levando em consideração as características e especificidades locais e/ou regionais, colocassem em bom termo a questão do desenvolvimento econômico. Faziase necessário, assim, romper com as amarras da teoria econômica convencional e construir um novo ferramental teórico e metodológico, capaz de apreender a organização e dinâmica periféricas como elas realmente eram, e não como meros “espelhos atrofiados” das economias industrializadas. Pode-se indagar se esses autores conseguiram, de fato, superar os marcos do quadro conceitual legado pela ciência econômica tradicional ${ }^{15}$, mas não restam dúvidas de que esse foi, ao menos, o espírito

\footnotetext{
12 SUNKEL, Osvaldo. "The development of development thinking”. The IDS Bulletin, East Sussex, volume 8, Issue 3, March 1977, p.8.

${ }^{13}$ Conforme demonstra Ha-Joon Chang, as políticas e instituições consideradas "boas" pelos economistas neoclássicos (abertura comercial, desregulamentação financeira, privatização, banco central politicamente independente, entre outras), não fizeram parte do leque de medidas adotadas pelos países economicamente maduros quando estes estavam em seu processo histórico de desenvolvimento; ao contrário, o desenvolvimento destas nações calcou-se primordialmente na adoção de políticas antiliberais e numa forte intervenção do Estado na economia. Na realidade, explica o autor, este pacote de "boa governança” nada mais representa do que uma tentativa dessas nações de chutar a escada por meio do qual elas próprias se utilizaram para alcançar o desenvolvimento, impedindo assim que os países retardatários utilizem-se das mesmas estratégias para superar o atraso. Vide CHANG, Ha-Joon. Chutando a escada - A estratégia do desenvolvimento em perspectiva histórica. São Paulo: Editora Unesp, 2003.

${ }^{14}$ Tratava-se, pois, de uma concepção muito particular do processo histórico "[...] a economia convencional concebia a História de maneira teleológica e unilinear, na qual os países desenvolvidos, e o que foi sua evolução e morfologia estrutural, representavam o futuro das economias "atrasadas". Como disse Althusser, concepção histórica à qual só cabe definir paradoxalmente: "um futuro anterior". MALLORQUIN, Carlos. Celso Furtado: um retrato intelectual. São Paulo: Xamã; Rio de Janeiro: Contraponto, 2005, p.28

${ }^{15}$ Octavio Rodriguez, por exemplo, sustenta que, dado a ênfase no processo de acumulação e a ausência de uma reflexão sobre a relação de exploração entre capital e trabalho, o pensamento da Cepal "[...] não supera os marcos da citada economia [clássica e neoclássica], aos quais, na verdade, se circunscreve”.
} 
intelectual que os animou em seus principais trabalhos e pesquisas, e que, simultaneamente, fomentou a criação da escola estruturalista latino-americana.

Embora o termo "estruturalista" tenha sido designado inicialmente para descrever o modo como os autores cepalinos lidavam com o problema da inflação ${ }^{16}$, seu alcance teórico-metodológico é muito mais amplo, designa o próprio modelo analítico utilizado nos diversos trabalhos da instituição para compreender a realidade econômica e social latino-americana. De acordo com a definição de um dos artífices dessa escola, o economista brasileiro Celso Furtado, - vista, no entanto, muitos anos após seu surgimento, e filtrada, portanto, pelo prisma do tempo -, o estruturalismo da Cepal:

[...] empenhou-se em destacar a importância dos parâmetros nãoeconômicos dos modelos macro-econômicos. Como o comportamento das variáveis econômicas depende em grande medida desses parâmetros, que se definem e evoluem num contexto histórico, não é possível isolar o estudo dos fenômenos econômicos em seu quadro histórico. Essa observação é particularmente pertinente com respeito a sistemas econômicos heterogêneos, social e tecnologicamente, como é o caso das economias subdesenvolvidas. [...] Como fatores "não-econômicos" - regime de propriedade de terra, controle das empresas por grupos com visão transnacional dos investimentos, permanência de grande parte de mão-de-obra de obra fora dos mercados organizados etc. integram a matriz estrutural do modelo com que trabalha o economista fomos chamados de estruturalistas. ${ }^{17}$

Ou ainda, segundo definição que retrata seus caracteres mais específicos:

O estruturalismo é um sistema analítico que tem por base a caracterização das economias periféricas por contraste às centrais: baixa diversidade produtiva (reduzida integração horizontal e vertical, insuficiência de infra-estrutura etc.) e especialização em bens primários; forte heterogeneidade tecnológica e oferta ilimitada de mão-de-obra com renda próxima à subsistência; e, por último, mas não menos importante, estrutura institucional pouco favorável ao progresso técnico e à acumulação de capital. A partir desse contraste, o estruturalismo inclui a análise das relações “centro-periferia”, isto é, a análise da forma específica de inserção internacional das economias da América Latina. ${ }^{18}$

RODRIGUEZ, Octavio. Teoria do subdesenvolvimento da Cepal. Rio de Janeiro: Forense-Universitária, 1981, p.24.

16 A teoria estruturalista da inflação foi inicialmente desenvolvida por VÁSQUEZ, Juan Noyola. “Inlfación y desarollo económico en Chile y México”. In: CEPAL, Cincuenta años de pensamiento en la Cepal - Textos Seleccionados, op. cit., p. 273-286. Posteriormente foi aprimorada por SUNKEL, Osvaldo. "La inflacion chilena: um enfoque heterodoxo”. In: Ibidem, p. 287-324.

17 FURTADO, Celso, “Entre inconformismo e reformismo”. In: Obra Autobiográfica. Tomo III. São Paulo: Paz e Terra, 1997, p. 16

18 BIELSCHOWSKY, Ricardo. Pensamento econômico brasileiro: o ciclo ideológico do desenvolvimentismo. 2a ${ }^{\mathrm{a}}$. ed. rev., Rio de Janeiro: Contraponto Editora, 1995, p. 111 
Portanto, os problemas econômicos que afligem(iam) o Brasil e a América Latina eram vistos, na interpretação estruturalista, como sendo resultantes de suas “desajustadas” estruturas produtiva, ocupacional, institucional, fundiária etc., e não por fatores monetários e/ou fiscais, como queriam os economistas de filiação neoclássica. E é precisamente pelo fato desses autores atribuírem o subdesenvolvimento às idiossincráticas estruturas econômicas e sociais periféricas, que dois eixos, praticamente inexistentes na teoria econômica convencional, adquirem enorme importância na análise, quais sejam, o espaço - que os permite caracterizar os diferentes pólos em que se organiza e se diferencia o sistema econômico mundial - e o tempo - que os habilita a assinalar as distintas trajetórias históricas que se perfilam em cada um desses pólos. Em síntese, a escola estruturalista inclui na interpretação econômica a geografia e a história.

O ponto de partida para a criação de uma escola estruturalista do pensamento econômico se deu, como se sabe, com os trabalhos do economista argentino Raúl Prebisch. Tendo ingressado na Cepal pouco após sua criação, em 1949, Prebisch foi seu segundo e mais importante diretor-executivo. Além do prestígio e liderança exercidos pelo economista argentino no contexto latino-americano ${ }^{19}$, contribuiriam também para isso a perspectiva teórica decisiva dos textos inaugurais da instituição, escritos por ele ou sob sua direta supervisão. Com efeito, as concepções presentes nesses primeiros trabalhos dariam a tônica para o tipo de produção teórica que viria a ser produzida pela recém-inaugurada instituição, oferecendo elementos catalisadores para a mesma e, simultaneamente, contribuindo para sua unidade analítica ulterior. Assim, as publicações seguintes da Cepal sobre temas tão variados como a inflação, o planejamento estatal, o mercado externo etc., carregariam muitos dos conceitos e caracterizações derivados desses primeiros documentos, em especial, aquele que é tido como o elemento axial do pensamento estruturalista, o sistema centro-periferia ${ }^{20}$.

\footnotetext{
${ }^{19}$ Antes mesmo de completar 40 anos, Prebisch já havia criado e dirigido o Banco Central de seu país na década de 1930, e sua bem sucedida gestão (ao menos aos olhos do mundo) no comando da economia argentina havia conferido-lhe grande prestigio internacional. Além disso, havia apenas dois anos que ele publicara uma obra de grande repercussão no pensamento econômico, intitulada Keynes - uma introdução, de 1947.

20 "Quiçá nenhuma idéia haja tido tanta significação na formação de uma visão nova do desenvolvimento como a de estrutura centro-periferia, formulada por Raúl Prebisch [...] O aprofundamento dessa idéia pelo próprio Prebisch e pelo grupo de cientistas sociais reunidos na Cepal - conhecidos posteriormente como escola estruturalista latino-americana - deu origens à corrente de pensamento de influência mais ampla e permanente nos estudos do desenvolvimento". FURTADO, Celso. Introdução ao desenvolvimento: enfoque histórico-estrutural. $3^{\text {a }}$. ed. São Paulo: Paz e Terra, 2000, p. 37. Ainda sobre isso, comenta
} 
Nas páginas iniciais do documento considerado o fundador da escola estruturalista, intitulado El Desarollo Económico de la America Latina y algunos de sus principales problemas - também conhecido como "Manifesto Latino-Americano" ${ }^{21}$ Prebisch introduz, de forma um tanto quanto contundente, a idéia de que o sistema econômico mundial organizava-se numa estrutura ou sistema centro-periferia.

La realidad está destruyendo en la América Latina aquel pretérito esquema de la división internacional del trabajo que, después de haber adquirido gran vigor en el siglo XIX, seguía prevaleciendo doctrinariamente hasta muy avanzado el presente. En ese esquema a América Latina venía a corresponderle, como parte de la periferia del sistema económico mundial, el papel específico de producir alimentos y materias primas para los grandes centros industriales. No tenía allí cabida la industrialización de los países nuevos. Los hechos la están imponiendo, sin embargo. Dos guerras en el curso de una generación, y una profunda crisis económica entre ellas, han demostrado sus posibilidades a los países de la América Latina, enseñándoles positivamente el camino de la actividad industrial. ${ }^{22}$

Vê-se, pois, que não era exatamente nova a idéia da divisão econômica do mundo em países produtores de matérias-primas e países produtores de bens industrializados - ao contrário, conforme argumenta Prebisch, esse esquema fora consagrado pela teoria e perpetuado pela prática econômica -, porém a grande intuição do economista argentino foi perceber as conseqüências, invertidas em relação ao que pregava ciência econômica tradicional, que a especialização produtiva trazia para os países produtores de bens primários, que ele denominou de periféricos ${ }^{23}$. Em outras palavras, eram desiguais os benefícios da divisão internacional do trabalho:

Joseph Love: "Para avaliar a importância dos termos "Centro e Periferia", devemos ter em mente que a idéia de que havia algo de fundamentalmente diferente nas economias das regiões "atrasadas" ainda era nova na década de 1940. O conceito de "subdesenvolvimento" como síndrome foi elaborado naquela década, principalmente após a criação das agências especializadas das Nações Unidas, em 1947-48. Os eufemismos "países em desenvolvimento" e "menos desenvolvidos” ainda estavam por vir.". LOVE, Joseph, op.cit., p. 308

${ }^{21}$ A expressão é de HIRSCHMAN, Albert. "Ideologies of economic development in Latin America”. In: A bias for hope: Essays on Development and Latin America. New Haven: Yale University Press, 1971, p. 280-281

22 PREBISCH, Raúl. “El Desarrollo Económico de La América Latina y algunos de sus principales problemas”. In: CEPAL, Cincuenta años de pensamiento en la Cepal - Textos Seleccionados, op. cit., p. 65.

${ }^{23}$ Embora tenha sido no "Manifesto" que Prebisch tenha formulado um sistema de relações centroperiferia, essa concepção não era inédita no pensamento do argentino. Joseph Love destaca que desde 1944, em palestras, e 1946, em forma impressa, Prebisch já adotava o termo periferia, embora naquele período tivesse um significado teórico mais limitado, basicamente restrito aos problemas enfrentados por essas economias nos períodos de contração cíclica do capitalismo. Cf. LOVE, Joseph., op.cit., p. 305 et. seq. 
Las ingentes ventajas del desarrollo de la productividad no han llegado a la periferia, en medida comparable a la que ha logrado disfrutar la población de esos grandes países [industrializados]. De ahí las diferencias, tan acentuadas, en los niveles de vida de las masas de estos y de aquélla, y las notorias discrepancias entre sus respectivas fuerzas de capitalización, puesto que el margen de ahorro depende primordialmente del aumento de la productividad. Existe, pues, manifestó desequilibrio, y cualquiera que fuere su explicación o el modo de justificarlo, se trata de un hecho cierto, que destruye la premisa básica en el esquema de la división internacional del trabajo. ${ }^{24}$

Portanto, o segredo por trás do pronunciado avanço econômico-social dos grandes países em relação à periferia, estava na forma e intensidade com que o aumento da produtividade difundia-se pelo aparelho produtivo desses países, bem como na maneira com que os frutos desse progresso eram absorvidos pela sociedade. A interpretação de Prebisch sobre a formação econômica dos EUA deixa bastante claro o papel da evolução técnica para o progresso social daquele país: "Es el aumento de la productividad lo que ha permitido a Estados Unidos y en menor grado a otros países industriales disminuir la jornada de trabajo, aumentar los ingresos reales de las masas y su nivel de vida, y acrecentar, en grado considerable, los gastos públicos. Todo esto, sin perjuicio de una ingente acumulación de capital”25. Assim, nas economias industrializadas ou centrais, o desenvolvimento das forças produtivas se dava num ritmo muito mais rápido que na periferia, irradiava-se de forma mais ou menos homogênea por todo o sistema produtivo e, por meio do aumento generalizado dos níveis de renda, beneficiava a coletividade como um todo. Por outro lado, nos países de produção primária, as técnicas produtivas difundiam-se de maneira muito mais lenta, concentravam-se basicamente nos setores agroexportadores ${ }^{26}$, formando verdadeiras ilhas de produtividade no meio de um deserto tecnológico, além de seus ganhos beneficiarem apenas uma pequena parcela da população. Ora, argumentava Prebisch, as conseqüências desse descompasso do desenvolvimento periférico em relação ao dos países centrais seriam anuladas, ou pelo menos, seriam bem menos drásticas, caso

\footnotetext{
${ }^{24}$ PREBISCH, Raúl, op. cit., p. 66.

${ }^{25}$ Idem, Ibidem, p. 102-103.

26 “La propagación universal del progreso técnico desde los países originarios al resto del mundo ha sido relativamente lenta e irregular, si se toma como punto de mira el de cada generación. [...]Dentro de esa periferia, el progreso técnico sólo prende en exiguos sectores de su ingente población, pues generalmente no penetra sino allí en donde se hace necesario para producir alimentos y materias primas a bajo costo, con destino a aquellos grandes centros industriales". CEPAL. "Estudio Económico de América Latina, 1949”. In: CEPAL. Cincuenta años de pensamiento en la Cepal - Textos Seleccionados, op. cit., p. 133.
} 
vigorassem no comércio internacional os princípios da teoria das vantagens comparativas.

Concebida no inicio do século XIX por David Ricardo ${ }^{27}$ e retomada por outros economistas clássicos e neoclássicos, a teoria das vantagens comparativas defendia, em linhas gerais, que a especialização produtiva naquilo que cada país possuía maiores vantagens relativas - no exemplo clássico de Ricardo, produção de vinhos em Portugal e de tecidos na Inglaterra - seria vantajosa para cada um deles, uma vez que a troca internacional desses produtos faria com que os benefícios econômicos da especialização fossem transferidos de país a país ${ }^{28}$. Desta forma, mesmo que o custo unitário da mãode-obra fosse menor em Portugal, seria mais vantajoso para esse país especializar-se na produção de vinho, com o que obteria em troca uma quantidade maior de tecidos do que se desviasse parte do capital produtivo empregado na vinicultura para a produção têxtil. Sob a ótica ricardiana, portanto, a industrialização dos países latino-americanos não traria prosperidade e sim prejuízo aos mesmos, já que representaria uma perda de eficiência econômica, dado a natural vocação agrária da região.

Num verdadeiro tour de force em relação à essas concepções, Prebisch não apenas negava que os benefícios da divisão internacional do trabalho se transferissem do centro para a periferia, como defendia o contrário, isto é, “mientras los centros han retenido íntegramente el fruto del progreso técnico de su industria, los países de la periferia les han traspasado una parte del fruto de su propio progreso técnico" ${ }^{29}$. A evidência empírica para esta afirmação estava num estudo da ONU sobre o comércio internacional entre 1876 e $1947^{30}$. Com base neste estudo, Prebisch constatou que os preços dos produtos manufaturados, ao invés de se reduzirem - como seria de se esperar segundo as teorias do equilíbrio do comércio internacional - haviam ficado mais caros em relação aos dos bens primários, fazendo com que, com o passar do tempo, mais unidades dos últimos fossem necessários para a obtenção da mesma quantidade dos primeiros. Ou seja, apesar da livre flutuação dos preços e dos períodos de valorização

\footnotetext{
${ }^{27}$ RICARDO, David. Princípios de Economia Política e Tributação. São Paulo: Victor Civita, 1982.

${ }^{28}$ Vale ressaltar que a tese de Ricardo tinha como pressupostos - mais ideológicos do que realistas, digase de passagem - a livre concorrência, vale dizer, a ausência de empresas com poder monopolístico, e a livre flutuação do preço da moeda.

${ }^{29}$ PREBISCH, Raúl, op.cit., p. 77.

${ }^{30}$ UNITED NATIONS. Relative Prices of Exports and Imports of Under-developed Countries: A Study of postwar terms of trade between under-developed and industrialized nations. New York, 1949.
} 
das commodities, havia, no longo prazo, uma tendência à deterioração dos termos de intercâmbio ${ }^{31}$ para os países exportadores de matérias primas e alimentos.

A explicação para essa deterioração, segundo a argumentação do "Manifesto", levava em consideração dois conjunto de fatores: o caráter cíclico do capitalismo e a dinâmica da estrutura produtiva e ocupacional de cada pólo do sistema mundial. Segundo Prebisch, nas economias centrais industrializadas, aquelas que comandavam o desenvolvimento tecnológico e desencadeiavam os ciclos, haveria uma contínua disparidade entre a demanda e oferta de produtos manufaturados (na fase crescente sua demanda ultrapassa a oferta, na fase minguante, o inverso), suscitando com isso reações cíclicas adaptativas na periferia. Nos ciclos econômicos ascendentes, os preços dos produtos primários teriam uma tendência a subir mais que o dos produtos industrializados, entretanto esse ganho seria insuficiente para repor as perdas geradas na fase minguante. Isso ocorreria, de acordo com Prebisch, porque nesse período, no centro, a organização política dos trabalhadores para evitar perdas salariais, por um lado, e o poder de suas empresas monopolistas, por outro, impediam a queda dos preços dos bens industriais, transferindo a pressão baixista sobre os preços para a periferia, que por sua vez, dado a desorganização característica das populações no campo, possibilitava uma contração mais que proporcional dos salários, incidindo, por essa via, nos preços das exportações primárias. Nesta espécie de jogo de soma-zero, “[...] cuanto menos pueden comprimirse así los ingresos en el centro, tanto más tendrán que hacer-lo en la periferia” ${ }^{32}$. Essa tendência à deterioração econômica era reforçada, ainda, pela mudança do centro cíclico mundial após a $1^{\mathrm{a}}$. Guerra Mundial, da Inglaterra para os EUA. Ao contrário da economia inglesa, a economia norte-americana se expandia reduzindo o coeficiente de importações (em bom português, praticando o protecionismo) o que gerava enormes dificuldades para os países produtores de bens primários exportarem suas mercadorias para o principal mercado consumidor do planeta.

No documento seguinte da Cepal, publicado em nome da instituição mas redigido pelo economista argentino, Prebisch imputaria o processo de deterioração

\footnotetext{
${ }^{31}$ O responsável pelo estudo no qual Prebisch se baseava, o economista Hans Singer, chegaria - de forma simultânea e independente - às mesmas conclusões que o argentino, daí muitos denominarem os achados deles de tese Singer-Prebisch. Cf. SINGER, Hans W. "The distribution of gains between investing and borrowing countries”. American Economic Review, vol. 40, n², American Economic Association: Menasha, 1949, p.473-485.

${ }^{32}$ PREBISCH, Raúl, op.cit., p. 81.
} 
menos ao caráter cíclico do capitalismo e às “pressões” do centro, do que à própria maneira com o que o progresso técnico era absorvido na periferia, assim como ao excesso de mão-de-obra do chamado setor pré-capitalista, isto é, a agricultura de subsistência.

[...] en última instancia, este fenómeno [deterioração dos termos de intercâmbio] se explica por la relativa lentitud con que el desarrollo industrial en el mundo va absorbiendo el exceso real o potencial de la población activa dedicada a las actividades primarias. El progreso técnico, ya lo sabemos, tiende a hacer que disminuya la población ocupada en la producción primaria. Pero esta disminución ha venido operándose históricamente con gran lentitud; mientras tanto, sobreviven otras innovaciones en la técnica productiva, que imponen la necesidad de nuevos reajustes en la distribución de la población ocupada.

Hay así, en general, una relativa abundancia de potencial humano en las actividades primaria, que tiende a presionar continuamente sobre los salarios y los precios de los productos primarios e impide así a la periferia compartir con los centros industriales el fruto del progreso técnico logrado por éstos. Más aún, impide a aquélla retener una parte del fruto de su proprio progreso técnico. ${ }^{33}$

Portanto, no Estudio Economico, a explicação para a deterioração dos termos de intercâmbio, e conseqüentemente, para o aumento da diferença do nível de renda entre os habitantes dos países centrais e dos periféricos, estava na maneira lenta e irregular com que a periferia absorvia o progresso técnico, dificultando assim a inclusão produtiva do enorme excedente populacional presente nos campos, o que por sua vez, impedia um aumento real dos salários dos trabalhadores ${ }^{34}$. Desta forma, os ganhos de produtividade não eram retidos pelas próprias economias periféricas, via aumento da renda-média da população, e sim transferidos às economias centrais, através da diminuição relativa do valor das matérias primas e alimentos que estes importavam daqueles, num esquema que Prebisch denominou de desenvolvimento "hacia fuera". Para agravar ainda mais as perspectivas econômicas dos países periféricos, Prebisch aponta uma série de fatores, tais como o crescimento meramente "vegetativo" da

\footnotetext{
${ }^{33}$ CEPAL. "Estudio Económico de América Latina, 1949”, op. cit., p. 136-137

${ }^{34}$ Prebisch argumenta que caso o mecanismo ricardiano da mobilidade de fatores produtivos funcionasse na economia real, seria de se esperar que o excedente populacional periférico, atraído pela maior oferta de empregos e pelos salários mais elevados, migrasse para os centros desenvolvidos, rebaixando os salários dessas regiões e equilibrando os níveis de renda entre os dois pólos do sistema mundial. Obviamente que isso não ocorria. Expondo com toda a polidez e descrição que um documento oficial da ONU requer, Prebisch diz que esse processo limitava-se às próprias economias centrais, isto é, os países industrializados, a fim de "proteger seu nível de vida", colocavam uma série de obstáculos para o livre deslocamento da força de trabalho, restringindo esse processo ao próprio âmbito doméstico, como por exemplo, nos Estados Unidos, onde as regiões industriais atraíam as populações das áreas periféricas de produção primária, geralmente localizadas ao sul daquele país. Idem, Ibidem, p. 139 et seq.
} 
demanda por alimentos, a utilização de técnicas poupadoras de matérias primas, a substituição de produtos naturais por produtos sintéticos, as medidas protecionistas dos pólos hegemônicos e a própria concorrência com os centros desenvolvidos, que faziam com que a demanda por produtos primários periféricos fosse pouco elástica. Por outro lado, esses países possuíam uma demanda de bens manufaturados importados dos países centrais muito superior à sua capacidade de comprá-los, gerando com isso os recorrentes e problemáticos déficits na balança de pagamentos, ou desequilíbrio externo.

Pois bem, o que fazer então para mudar essa dinâmica perversa do desenvolvimento latino-americano? A solução proposta por Prebisch e pela escola estruturalista é bem conhecida. Tratava-se, pois, de inverter o padrão de desenvolvimento desses países, isto é, de um modelo de crescimento orientado para e condicionado a partir de fora, para um “desarollo desde dentro", mediante o advento da industrialização. Dado o baixo dinamismo do setor primário da economia, que via seus preços no mercado internacional despencarem, e sua incapacidade estrutural de absorver o excedente populacional, não bastava - ainda que fosse necessário - elevar a produtividade deste setor, com o que, como Prebisch havia bem demonstrado, “exportava-se” o desenvolvimento. Era imprescindível uma transformação qualitativa na maneira de crescer dessas economias, acelerando substancialmente o ritmo de acumulação capitalista e alterando a composição orgânica do capital. Deste modo, possibilitar-se-ia uma robusta elevação da produtividade do sistema econômico como um todo, simultâneamente à incorporação produtiva de enormes massas urbanas e rurais alheios ao processo de desenvolvimento. E a principal, ou única maneira de se obter isso seria através de um vigoroso e contínuo esforço de industrialização: "No es ella un fin en sí misma [a industrialização], sino el único medio de que disponen éstos [países latino-americanos] para ir captando una parte del fruto del progreso técnico y elevando progresivamente el nivel de vida de las masas”35. Por meio da industrialização, defendia Prebisch, haveria transferência de mão-de-obra de setores de reduzida produtividade, como a agricultura de subsistência, para o setor industrial, elevando simultaneamente a produtividade da economia e a renda-média da população ${ }^{36}$. Com isso, haveria uma expansão do mercado interno, trazendo novas

\footnotetext{
${ }^{35}$ PREBISCH, Raúl, op. cit., p. 66, grifo nosso.

${ }^{36}$ Prebisch e a escola estruturalista não sustentavam, como afirmam alguns de seus críticos liberais, a tese ingênua de que produtividade da indústria era maior que a da agricultura (basta-nos lembrar que, na acepção estruturalista original, o setor mais avançado de uma economia tipicamente periférica era
} 
oportunidades de inversão e ocupação na indústria, realimentando assim o ciclo virtuoso. Os benefícios desse processo não se restringiriam, contudo, ao setor industrial, ao contrário, se propagariam por todo o aparelho produtivo, anulando, inclusive, a tendência à deterioração dos termos de intercambio: “La industrialización, al aumentar la productividad, hará subir los salarios y encarecerá relativamente el precio de los productos primarios. De este modo, al subir sus ingresos, la producción primaria irá captando en forma gradual aquella parte del fruto del progreso técnico que le hubiera correspondido por la baja de los precios” ${ }^{37}$. A elevação e homogeneização dos níveis tecnológicos da estrutura produtiva permitiriam assim diminuir as desigualdades sociais e regionais, impulsionar o crescimento econômico e, simultaneamente, liquidar as bases dos problemas estruturais das economias periféricas, tal como o excedente de mão-deobra.

Entretanto, a industrialização dos países periféricos, que Prebisch vira surgir como uma reação espontânea, e um tanto quanto caótica, à crise dos grandes centros (duas guerras mundiais e a grande depressão), não deixava de gerar, ela própria, desequilíbrios nessas economias. Dado a estrutura econômica e institucional subdesenvolvida sobre a qual se assentava (heterogeneidade tecnológica, baixo nível de poupança interna ${ }^{38}$, reduzido mercado consumidor, entre outros ${ }^{39}$ ) o processo de industrialização levado a cabo na América Latina, posteriormente denominado de

justamente o setor agroexportador). A vantagem fundamental da indústria para os autores cepalinos estava em sua maior capacidade de absorver o contingente populacional não ocupado ou sub-ocupado no setor de subsistência, bem como aquelas populações expulsas pela mecanização da agricultura. E isso se dava, fundamentalmente, porque o crescimento da produção industrial gerava efeitos dinâmicos em toda a cadeia produtiva - teria, na expressão de Hirschman, maior potencial de gerar encadeamentos - o que não ocorria, na mesma proporção, quando do crescimento da produção primária. Além disso, com a industrialização, seria possível manter dentro da própria economia os ganhos de produtividade que, de outra maneira, seriam transferidos para os países centrais, mediante a importação de artigos manufaturados. Portanto, diferentemente da agricultura, a indústria teria a capacidade de gerar, de maneira firme e consistente, o crescimento econômico e o aumento do nível ocupação.

${ }^{37}$ Idem, Ibidem, p. 83.

${ }^{38}$ Embora para Prebisch o baixo nível de poupança periférico fosse resultado, em primeira instância, da baixa produtividade da economia, já no "Manifesto" ele aponta um fator subsidiário, que os autores estruturalistas, e especialmente Celso Furtado, iriam dar grande destaque a partir dos anos 1960, isto é, o padrão suntuoso de consumo das elites: "Pero la escasez típica de ahorro, en grande parte de América Latina, no solo proviene de aquel estrecho margen, sino también de su impropia utilización, en casos muy frecuentes. El ahorro significa dejar de consumir, y por tanto, es incompatible con ciertas formas peculiares de consumo en grupos con ingresos relativamente altos”. Idem, Ibidem, p. 102.

${ }^{39}$ No essencial, essas deficiências confluíam para uma mesma problemática: o insuficiente ritmo de formação e acumulação de capital diante das elevadas, e crescentes, exigências de capitalização do moderno processo de industrialização. Daí que: “[...] cuanto más tarde llega la técnica moderna a un país de periferia, tanto más agudo es el contraste entre el exiguo monto de su ingreso y la considerable magnitud del capital necesario para aumentar rápidamente ese ingreso". CEPAL, "Estudio Económico de América Latina, 1949”, op. cit., p. 157. 
modelo de substituição de importações ${ }^{40}$, tendia a provocar uma série de distorções de ordem econômicas e sociais. Nesse sentido, se por um lado o advento de um processo substitutivo de importações contribuía para elevar a produtividade média do sistema produtivo e diminuir a dependência externa de bens de consumo, por outro, ele aumentava exponencialmente a demanda por máquinas e equipamentos - itens essencialmente importados dos países centrais - cujas exigências em termos de capital eram absolutamente incompatíveis com o nível de poupança dos países periféricos, reforçando destarte a tendência ao estrangulamento externo. Da mesma forma, a inflação surgia como uma conseqüência inevitável, e até certo ponto necessária, do advento da industrialização, já que com a expansão da oferta do crédito e da moeda, permitia-se a dar continuidade ao crescimento econômico, não obstante as restrições na capacidade de importar desses países. No entanto, a conseqüência mais grave, do ponto de vista do aspecto social, era que enquanto o processo de industrialização periférica não atingisse a maturidade, vale dizer, enquanto, não constituísse plenamente um setor de bens de capital, continuar-se-ia exportando empregos e desenvolvimento para o centro:

En la periferia, el progreso técnico trae consigo desocupación, como en los centros, pero la demanda de bienes de capital inherente a ese progreso no se manifiesta en aquélla como en éstos, pues en la primera faltan las industrias de capital; por consiguiente, la demanda referida, en lugar de reflejarse en la economía del país en desarrollo, pasa a causar efecto en la economía de los centros industriales, en donde se producen esos bienes de capital. ${ }^{41}$

Para Prebisch, esses e inúmeros outros obstáculos intrínsecos à industrialização periférica conduziam a uma só alternativa: fazia-se necessária a presença do Estado para a coordenação e racionalização de todo esse processo. Diante das limitações da capacidade de importação, do baixo nível de poupança interna, do reduzido mercado consumidor e das falhas de mercado (ainda mais graves na periferia que no centro), caberia aos Estados nacionais das nações em desenvolvimento a função de conduzir o processo de desenvolvimento industrial, seja por meio da intervenção direta (empresas estatais ou investimentos diretos) ou indireta (incentivos e isenções ficais à indústria, subsídios, controle de preços etc.). A fim de se otimizar a alocação de fatores produtivos

\footnotetext{
${ }^{40}$ Cf. TAVARES, Maria da Conceição. “Auge y declinación del proceso de substitución de importaciones en el Brasil”. In: CEPAL. Cincuenta años de pensamiento en la Cepal - Textos Seleccionados, op. cit., p. 207-228

${ }^{41}$ CEPAL, “Estudio Económico de América Latina, 1949”, op. cit., p. 160.
} 
e contornar a crônica escassez de recursos das economias, as decisões de investimento e de importações deveriam ser meticulosamente tomadas, valendo-se para isso do uso de modernas técnicas de planejamento e planificação. Daí também porque Prebisch admitia o concurso transitório do capital estrangeiro, desde que limitado a setores nãoestratégicos e, naturalmente, submetido ao controle e fiscalização estatais. Mas talvez o principal componente da política desenvolvimentista sustentada pelo economista argentino sejam as medidas protecionistas. Em sua concepção, o protecionismo era uma ferramenta indispensável para que a indústria nascente dos países em desenvolvimento pudessem concorrer com as poderosas industrias dos países centrais ${ }^{42}$. Além do mais, com as políticas de proteção permitir-se-ia aliviar a demanda externa de determinados produtos, liberando a pauta de importações para outros bens necessários à industrialização substitutiva. Cumpre observar contudo que, para Prebisch, o protecionismo não era um expediente a ser utilizado de maneira indiscriminada e irrestrita, mas sim de forma temporária - enquanto perdurassem as diferenças de produtividade entre centro e periferia -, parcimoniosa - sem o que levava ao desestímulo à eficiência produtiva - e limitada a certos ramos industriais - sem o que poderia levar a um crescimento insustentável da atividade econômica.

Diversas outras medidas sugeridas pelo economista argentino e pelos autores cepalinos para alavancar o desenvolvimento periférico poderiam ser aqui arroladas. Não cabe aqui citá-las todas ${ }^{43}$. O mais importante a ser dito, entretanto, é que todas elas desembocavam numa mesma conclusão de caráter normativo: a superação do atraso periférico só seria possível mediante um intenso processo de industrialização induzido e coordenado pelo Estado. Para tanto, era mister uma amplo arco de alianças, formada pelos setores mais progressistas da sociedade, isto é, a burguesia industrial, os trabalhadores urbanos e a burocracia estatal, que, contrariando os interesses das oligarquias rurais e dos centros desenvolvidos - que se beneficiavam largamente da

\footnotetext{
42 Aliás, contrariando os ideólogos do livre cambismo, Prebisch afirmava que, exceto obviamente a Inglaterra, os países que se seguiram na corrida industrializante, haviam se utilizado, sem nenhuma exceção, de políticas protecionistas. Idem, Ibidem, p. 170-171

${ }^{43}$ Para uma avaliação das demais medidas a serem tomadas pelos países periféricos veja-se PREBISCH, Raúl. "Hacia una nueva política comercial en pro del desarollo". In: CEPAL, Cincuenta años de pensamiento en la Cepal - Textos Seleccionados, op. cit., p.349-398.
} 
especialização periférica na produção de bens primários - dessem amparo às medidas e planos governamentais de apoio à indústria nacional ${ }^{44}$.

As idéias de Prebisch e da Cepal tiveram grande impacto no debate desenvolvimentista dos anos 1950, especialmente no Brasil e no Chile, embasando direta ou indiretamente diversas políticas econômicas desses e de outros países da região. Para além das medidas práticas de cunho desenvolvimentista, isto é, no campo teórico-metodológico, as reflexões de Prebisch sobre o pensamento econômico e as condições periféricas não se fizeram menos notadas e perfilhadas. Particularmente influente foi sua proposição téorica-metodológica de que as abstratas e desgastadas formulas da ciência econômica tradicional não poderiam ser aplicadas no contexto latino-americano; para melhor visualizar este quadro, bem como para propor efetivas alternativas a ele, far-se-iam necessárias novas lentes, condizentes com as idiossincráticas condições econômicas e sociais do continente ibérico. Não demorou muito para os técnicos da Cepal, entre eles Juan Noyola Vásquez, Anibal Pinto, Osvaldo Sunkel, Maria da Conceição Tavares, entre outros, se apropriarem desse discurso e darem suas próprias e originais contribuições para o estudo econômico do desenvolvimento capitalista na periferia. Sem embargo, quem talvez tenha feito um uso mais fecundo do esquema teórico proposto por Prebisch, ampliando-o e difundi-o para um público mais amplo, tenha sido o economista brasileiro Celso Furtado.

\footnotetext{
${ }^{44}$ As proposições políticas dos autores cepalinos raramente se afiguram nos textos e documentos oficiais da instituição (pelo menos até a décade de 1960) da maneira explícita e inequívoca como foram acima expostas, afinal a Cepal era uma instituição de caráter eminentemente "técnico" e, no que se refere à política interna dos países, supostamente neutra. Além do mais, como qualquer órgão da ONU, a Cepal dependia dos recursos e da aprovação dos mesmos centros desenvolvidos as quais as críticas eram direcionadas. Ainda assim, a fundamentação política é inextricável ao pensamento cepalino, como inúmeros críticos e comentadores já trataram de demonstrar. Pode-se mesmo afirmar que, dado a primazia político-social conferida à burguesia industrial e o papel "tutelador" atribuído ao Estado, "[...] o pensamento da Cepal dos anos cinqüenta constitui a forma mais abstrata e, ao mesmo tempo, mais desenvolvida e coerente de um posto de vista analítico das ideologias de caráter populista”. RODRIGUEZ, Octavio, op. cit., p.266.
} 


\subsection{Celso Furtado e a historicização do subdesenvolvimento}

Se Raúl Prebisch é considerado o fundador da escola estruturalista latinoamericana, dificilmente esta escola teria o prestígio e a influência que exerceram não fossem as contribuições, perspectivas e empenho de seu colega de instituição, o então jovem economista brasileiro Celso Furtado. Tendo trabalhado na Cepal desde sua fundação até 1957, Furtado se utilizaria com grande criatividade de diversos conceitoschave formulados por Prebisch e seria autor e co-autor de outras tantas formulações no âmbito da agência da ONU para a América Latina (participando inclusive da elaboração do famoso Estudio, de 1949). Em realidade, a perspectiva teórica e o posicionamento político de ambos convergiam em muitos pontos. Assim como seu colega argentino, Furtado acreditava que o estudo do subdesenvolvimento requeria um "esforço de teorização autônomo”, ao mesmo tempo em que postulava que a superação dessa condição se daria através de um decidido esforço de industrialização "voltado para dentro”, incorporando à modernidade milhões de pessoas vivendo às margens do progresso. Também compartilhava com Prebisch uma certa "aura keynesiana”45 de que a coordenação desse processo devia ser tarefa do Estado, uma vez que faltariam ao mercado a racionalidade e a visão estratégica necessárias para conduzir um desenvolvimento econômico de longo prazo. E, assim como seu colega argentino, Furtado batalharia para "pôr em prática” as idéias daquele fértil período, seja através dos estudos e planos de desenvolvimento elaborados na Cepal para diversos governos nacionais da região, seja por meio de sua direta participação, enquanto membro do primeiro escalão da administração pública brasileira, em três sucessivas gestões (Kubistchek, Quadros e Goulart) ${ }^{46}$. Não obstante, e sem prejuízo de sua importância na vida pública enquanto policy maker, é no campo do pensamento social que o legado do economista brasileiro mais se destaca. Além da prolífica produção intelectual e da elevadíssima tiragem de seus livros ${ }^{47}$, Celso Furtado representa uma espécie de elo

\footnotetext{
${ }^{45}$ BIELSCHOWSKY, Ricardo, op. cit., p. 135.

${ }^{46}$ Furtado participara também, embora sem um cargo executivo, do governo Vargas, chefiando o Grupo Misto CEPAL-BNDE, que elaborou o Esboço de um Programa de Desenvolvimento para o Brasil, que serviria de base para o Programa de Metas de Juscelino Kubitscheck.

47 “A julgar pela divulgação de seus trabalhos, resta pouca dúvida de que Celso Furtado seja o cientista social brasileiro mais influente de todo o século. Na América Latina, onde os livros, em geral, são publicados em tiragens de um a dois mil exemplares, as obras de Furtado, em 1972 já haviam vendido cerca de duzentos mil exemplares em espanhol e português. As vendas de suas obras, em todo o mundo, atingiram um milhão de exemplares em 1990, sendo que a metade deles foi publicada na América Latina.
} 
entre muitas correntes e tradições teóricas do pensamento social brasileiro e latinoamericano: da geração dos ensaístas ${ }^{48}$ à moderna ciência econômica e social brasileira; do incipiente desenvolvimentismo de Roberto Simonsen nos anos 30/40, à madura ideologia do desenvolvimento nacional dos anos $50^{49}$; do estruturalismo prebischiano, a seu próprio enfoque estruturalista, mais preocupado com os desencadeamentos históricos que a perspectiva do economista argentino (não seria exagerado afirmar que se deve a Furtado o vocábulo histórico no termo método histórico-estrutural); e, finalmente, no ponto que mais interessa para o presente trabalho, do estruturalismo da Cepal à teoria da dependência. Curiosamente, suas maiores contribuições para o pensamento estruturalista ocorreram quando Furtado já não mais pertencia aos quadros da instituição da ONU para a América Latina; trata-se dos clássicos Formação Econômica do Brasil (1959) e Desenvolvimento e Subdesenvolvimento $(1961)^{50}$. Foi justamente no período em que Furtado esteve mais diretamente envolvido com a administração pública brasileira que o economista brasileiro publicou essas que são algumas das obras de maior envergadura do estruturalismo latino-americano, influenciando sucessivas gerações de cientistas sociais e, simultaneamente, introduzindo elementos analíticos importantes para o surgimento da escola dependentista alguns anos mais tarde ${ }^{51}$.

Ele foi o primeiro, o mais original e o mais prolífico dos autores estruturalistas brasileiros.” LOVE, Joseph, op. cit., p.359

48 "Antonio Candido de Mello e Souza, fundador, entre outros, da moderna teoria literária, chamou o trio de autores da década de 1930, Gilberto Freyre, Sérgio Buarque de Holanda e Caio Prado Jr., de demiurgos do Brasil, no sentido de que elaboram interpretações que moldaram, definitivamente, nossa madeira de compreender a formação da sociedade, do Estado e da nação, com suas formas sociais, economias, políticas e culturais, com seus estigmas e modos de relacionamento que nos imprimiram um selo especial. [...] Celso Furtado, junta-se, com justiça, a esse seleto grupo - ao qual, de resto, também pertence o próprio Antonio Candido com seu Formação da literatura brasileira - atualizando, renovando, marcando as rupturas e sobretudo porque ele apanha o intenso processo de industrialização que se acelera a partir da Revolução de 1930." OLIVEIRA, Francisco de. "Formação econômica do Brasil: gênese, importância e influências teóricas”. In: A navegação venturosa: ensaios sobre Celso Furtado. São Paulo: Boitempo Editorial, 2003, p. 83-84.

${ }^{49}$ Simonsen falece em 1948, ano em que, por uma coincidência histórica, a Cepal inicia suas atividades. A partir de então, seriam os técnicos da instituição - e, especialmente no contexto brasileiro, Celso Furtado - quem provavelmente melhor fundamentariam a defesa da industrialização e a necessidade do planejamento e incentivo estatais como condições para o desenvolvimento. Sobre isso, vide BIELSCHOWSKY, Ricardo, op. cit., p.77-180

${ }^{50}$ Também importantes, embora de um período posterior, afiguram Teoria e Política do Desenvolvimento (1967) - cujas diversas edições iriam reciclar, reformular e ampliar muito do conteúdo de Desenvolvimento e Subdesenvolvimento - e A economia latino-americana (1969).

${ }^{51}$ Não são poucos os que consideram Celso Furtado como o progenitor ou como o primeiro dos analistas da dependência. Sem dúvida, como tentaremos demonstrar nessa seção, as análises e considerações do economista brasileiro representaram um importante avanço no quadro teórico-metodológico do estruturalismo, no sentido de incorporar com mais firmeza os condicionantes históricos e sociológicos do processo de subdesenvolvimento. Nesse sentido, é indiscutível que a obra de Furtado do final dos anos 
Em resenha a um dos mais completos livros sobre o pensamento de Celso Furtado $^{52}$, Gildo Marçal Brandão ${ }^{53}$ sintetiza nos seguintes tópicos os principais aspectos e legados da obra do economista brasileiro: 1) a análise histórico-estrutural da economia; 2) a historicização do estruturalismo cepalino; 3) a idéia de que o subdesenvolvimento não é uma etapa pela qual as economias atualmente desenvolvidas tenham percorrido, e sim um produto da expansão capitalista mundial rumo às regiões periféricas do globo; 4) a concepção de que a relação dicotômica centro-periferia reproduz-se também no âmbito interno dos países dependentes, por meio de fenômenos econômico-sociais (heterogeneidade estrutural e dualismo econômico) que podem pôr em risco a unidade do Estado; 5) a crítica à teoria das vantagens comparativas; 6) a necessidade da intervenção e do planejamento estatal, dado a incapacidade do mercado de se auto-regular. A esses pontos, talvez possam ser acrescidos outros dois: a dimensão cultural do (sub)desenvolvimento (que ocuparia o centro de suas atenções a partir do final dos anos 1960); e um ponto que apenas recentemente passou-se a ter o devido reconhecimento em sua obra, qual seja, a democracia como condição indispensável para a solução dos conflitos e tensões distributivas, e como meio de edificação da $\mathrm{Nação}^{54}$. Sem embargo, são os três ou quatro primeiros pontos anteriormente citados as principais contribuições de Furtado à matriz teórica do estruturalismo, alargando seu escopo analítico inicial e trazendo algumas das concepções que os autores dependendistas iriam mais tarde se aproveitar ou desenvolver em maior profundidade. Limitemo-nos, portanto, a eles.

A introdução do componente histórico ao sistema analítico originalmente desenvolvido por Prebisch é, segundo a maioria de seus comentadores, e de acordo com

1950 e inicio dos anos 1960 situe-se já nos liames metodológicos e conceituais de uma teoria sobre a dependência em países de desenvolvimento capitalista retardatário. Entretanto, a teoria da dependência, a despeito de empregar muitas das concepções estruturalistas, surge inicialmente como uma perspectiva analítica (e política) de ruptura em relação ao reformismo dos autores cepalinos, e particularmente, com a premissa furtadiana de “internalização dos centros de decisão". Voltaremos a essa discussão mais à frente. Para uma exposição de Celso Furtado como o pioneiro das análises da dependência vide LOVE, Joseph. op. cit, p.360-403, e também MALLORQUIN, Carlos, op. cit., p. 327-346.

52 Cf. BRESSER-PEREIRA, Luiz Carlos; REGO, José Márcio (Orgs.). A grande esperança em Celso Furtado: ensaios em homenagem aos seus 80 anos. São Paulo: Editora 34, 2001

53 BRANDÃO, Gildo Marçal. "Celso Furtado: O peregrino da ordem do desenvolvimento". Revista República, São Paulo, 2002, p.105-109

${ }^{54}$ Deve-se, sobretudo, a Vera Alves Cepêda o "resgate” dessa importante dimensão na obra de Furtado. A esse respeito, vide seu artigo no referido livro de homenagem a Celso Furtado. CEPÊDA, Vera Alves. "O pensamento político de Celso Furtado: desenvolvimento e democracia”. In: BRESSER-PEREIRA, Luiz Carlos; REGO, José Márcio (Orgs.), op. cit., p.167-184. Para uma exposição mais detalhada, cf. CEPÊDA, Vera Alves. Raízes do pensamento político de Celso Furtado: desenvolvimento, nacionalidade e Estado democrático. 1998. 236f. Dissertação (mestrado em Ciência Política) - Faculdade de Filosofia, Letras e Ciências Humanas, Universidade de São Paulo, São Paulo, 1998. 
a avaliação do próprio autor ${ }^{55}$, uma das maiores contribuições de Furtado ao estruturalismo latino-americano. É bem verdade que Prebisch já tinha sinalizado para esse componente quando, em suas análises seminais na Cepal, examinara as tendências de longo prazo das economias centrais e periféricas, e caracterizara a diferenciação das últimas em relação às primeiras como resultado da divisão internacional do trabalho do século XIX, que seguia vigorando doutrinariamente. Entretanto, conforme assinala Furtado, a análise de Prebisch não captava os desencadeamentos históricos deflagrados por essa estruturação econômica mundial, limitando-se a investigar, de maneira “sincrônica”, a dinâmica dos ciclos e suas conseqüências para cada pólo do sistema ${ }^{56}$. Para o economista brasileiro interessavam, sobretudo, os processos históricos que, no longo prazo, formavam ou conformavam as estruturas sociais subdesenvolvidas; o que para Furtado significava não apenas entender os efeitos provocados na periferia pelos ciclos, como também a dinâmica social periférica em reação a eles. É interessante observar que, mesmo antes de seu ingresso na Cepal, em sua tese de doutoramento, defendida em 1948, Furtado já vinha atentando para os fatores históricos e sociológicos que, no interior de uma economia periférica como a brasileira, levavam ao atraso ${ }^{57}$. Porém, seria durante sua passagem pelo órgão da ONU para a América Latina, e principalmente, já em seu retorno ao Brasil - após breve período de estudos em Cambridge - com a publicação das duas obras anteriormente citadas, que Furtado desenvolveria em plenitude seu enfoque histórico-estrutural. Pois bem, e no que consistia esse enfoque?

Em linhas gerais, trata-se de conceber o desenvolvimento periférico (ou, de acordo com o termo mais freqüentemente utilizado pelo economista, o subdesenvolvimento) como um processo resultante e integrante do movimento de expansão da economia capitalista internacional, enfatizando, assim, seu caráter ao

\footnotetext{
${ }^{55}$ Cf. LOVE, Joseph, op. cit., p.398

56 "A visão de Prebisch era essencialmente sincrônica: assinalava uma descontinuidade estrutural no sistema capitalista, geradora de dinâmicas distintas nos segmentos central e periférico. Quando comparava o comportamento do sistema na época em que o centro principal era a Grã-Bretanha com o da época em que esse centro principal era a Grã-Bretanha com o da época em que esse centro passou a ser os Estados Unidos, ele se limitava a fazer a interface dos dois cortes sincrônicos. Interessava-me captar o desenrolar dos acontecimentos no tempo, o encadeamento dos fatores que perpetuavam o clamoroso atraso da economia brasileira”. FURTADO, Celso. "A fantasia organizada”. In: Obra Autobiográfica. Tomo I. São Paulo: Paz e Terra, 1997, p. 163.

${ }^{57}$ Neste aspecto, há um interessante diálogo entre os textos de Furtado, explicitado em sua tese de doutorado, e a dos "novos clássicos" da modernidade brasileira, isto é, Freyre, Buarque de Holanda e, especialmente, Prado Jr. A esse respeito veja-se RICUPERO, Bernardo. "Celso Furtado e o pensamento social brasileiro”. Estudos Avançados, São Paulo, vol. 19, n53, 2005, p.371-377
} 
mesmo tempo histórico e global. Assim, a formação e reprodução das estruturas tipicamente subdesenvolvidas da periferia (o padrão concentrado e “inflexível” da distribuição de renda, o excedente estrutural de mão-de-obra, a heterogeneidade tecnológica do aparelho produtivo etc.) vinculam-se à forma peculiar com que essas regiões foram incorporadas ao mercado mundial: especializadas na produção primária, economicamente subordinadas e tecnologicamente dependentes. O enfoque históricoestrutural de Furtado não se limita, todavia, a registrar o processo de desenvolvimento da periferia como uma simples decorrência do processo global da economia - o que seria uma pobre simplificação de suas idéias. Na perspectiva analítica furtadiana, tão importante quanto esmiuçar os meandros da dinâmica capitalista internacional estava em entender como que os mesmos coadunam-se e se inter-relacionam com os processos históricos engendrados no interior da própria periferia. Talvez o melhor exemplo de como Furtado emprega a abordagem histórico-estrutural no estudo do desenvolvimento econômico encontra-se em Formação Econômica do Brasil. Neste clássico ensaio, Furtado retrata como a montagem de uma economia primário-exportadora como a brasileira, resultado do processo histórico de expansão mercantilista européia, se por um lado cumpriu o papel de integrá-la ao circuito econômico mundial, como fornecedora de matérias-primas e alimentos, por outro lado, produziu uma estrutura econômica e social pouca dinâmica (dependente do ciclo econômico da vez: açúcar, ouro, café etc.), de baixa produtividade-média, incapaz de absorver o "reservatório substancial de mão-deobra” e, conseqüentemente, de formar um efetivo mercado interno, condição necessária, na acepção estruturalista, para a internalização do desenvolvimento.

Utilizando-se de uma estratégia metodológica análoga à empregada alguns nos antes por Prebisch em seu famoso "Manifesto", Furtado toma como exemplo e contraponto histórico para sua análise a formação econômica dos Estados Unidos. Embora as colônias de povoamento do Hemisfério Norte, argumenta Furtado, tivessem representado para suas metrópoles um estrondoso fracasso comercial ${ }^{58}$, “[...] nelas era muito menor a concentração de renda, e as mesmas estavam muito menos sujeitas a

\footnotetext{
58 "Do ponto de vista das companhias que financiaram os gastos iniciais de translado e instalação, a colonização dessa parte da América constitui um efetivo fracasso. Não foi possível encontrar nenhum produto, adaptável à região, que alimentasse uma corrente de exportação para a Europa capaz de remunerar os capitais investidos. Com efeito, o que se podia produzir na Nova Inglaterra era exatamente aquilo que se produzia na Europa, onde os salários estavam determinados por um nível de subsistência extremamente baixo, na época. Demais, o custo de transporte era de tal forma elevado, relativamente ao custo de produção dos artigos primários, que uma diferença mesmo substancial nos salários reais teria sido de escassa significação.”. FURTADO, Celso. Formação Econômica do Brasil. 14a . ed. São Paulo: Cia. Editora Nacional, 1976, p.22
} 
bruscas contrações econômicas. Demais, a parte dessa renda que revertia em benefício de capitais forâneos era insignificante. Em conseqüência, o padrão médio de consumo era elevado, relativamente ao nível da produção per capita" ${ }^{59}$. Não sendo possível obter a exploração rentável de produtos demandados pela metrópole, constituiu-se nessas regiões uma economia semelhante à própria economia dos centros europeus: baseado na pequena propriedade privada, na mão-de-obra livre, na produção para o mercado doméstico e cujo dinamismo econômico era essencialmente endógeno ("autopropulsão”), isto é, os lucros gerados eram reinvestidos na própria economia, de modo a permitir um aumento da produtividade e da renda-média da população. Situação bastante distinta das regiões de colonização baseada no trabalho escravo e na grande plantação, como a economia de “tipo colonial” brasileira. Nela, argumenta Furtado, além do impulso depender quase que inteiramente da demanda externa, o crescimento não implicava em grandes ganhos de produtividade e não conduzia à diversificação da estrutura produtiva, bem ao contrário, antes reforçava essa mesma estrutura, uma vez que a expansão econômica dependia tão-somente da exploração de novas terras (sempre disponíveis) e do aumento de importações (essencialmente mão-de-obra escrava). Além do que, dado a estrutura altamente concentrada de renda e de terra, os ganhos econômicos convertiam-se no enriquecimento de uma pequena elite agrária, que despendia boa parte de seus lucros em artigos de consumo importados (daí que o efeito multiplicador keynesiano “vazasse” para o exterior). Tampouco nos períodos de contração cíclica criar-se-iam tensões sociais suficientemente fortes para romper esse quadro estrutural: "Decadência vinha a ser redução dos gastos em bens importados e na reposição da força-de-trabalho (também importada), com diminuição progressiva, mas lenta, no ativo da empresa, que assim minguava sem se transformar estruturalmente" ${ }^{\text {. }}$. Nesses períodos, a parcela da população livre que se via desempregada contribuía para engrossar o caldo do setor de subsistência (de baixíssima produtividade); processo que para Furtado consistia num dos principais mecanismos históricos do subdesenvolvimento ${ }^{61}$. Explicava-se assim porque que o desenvolvimento da economia colonial não conduzia senão a uma ampliação das estruturas subdesenvolvidas: num

\footnotetext{
${ }^{59}$ Idem, Ibidem, p.30-31

${ }^{60}$ Idem, Ibidem, p.52

${ }^{61}$ Foi precisamente este mecanismo - de transferência populacional do setor de maior produtividade para o setor de subsistência, ou seja, de involução econômica - que, na interpretação de Furtado, possibilitou o Nordeste brasileiro atravessar seguidos séculos de decadência econômica e, simultaneamente, formar a sua tão característica e atrasada estrutura social. Daí se vê porque a análise de Furtado é ao mesmo tempo histórica e estrutural.
} 
caso, de crescimento econômico, levava à reprodução homóloga das estruturas de produção, à concentração de renda e à transferência de recursos para o exterior; noutro caso, na fase depressiva, gerava degradação social, rebaixamento do nível de produtividade e ainda mais concentração de renda.

Para Furtado, essa dinâmica do desenvolvimento brasileiro teria permanecido praticamente inalterada até metade do século XIX, quando surgira então um novo surto, o do café, que modificaria as bases do sistema econômico pré-existente: seu grau de capitalização era comparativamente mais baixo; seus níveis de rentabilidade e aproveitamento da força-produtiva eram altos (o que, devido ao encarecimento do trabalho escravo e sua posterior abolição, impulsionaria o trabalho livre); e seus dirigentes tinham maior consciência e ambição políticas que os grupos dominantes dos ciclos anteriores. Essas condições teriam favorecido o alargamento do mercado interno, o desenvolvimento dos transportes e das comunicações, o fortalecimento do setor urbano da economia e até mesmo o surgimento de um incipiente processo de industrialização ${ }^{62}$. Por outro lado, por ser uma economia mais monetizada, devido ao trabalho assalariado, também era mais vulnerável aos choques externos e às contrações cíclicas do mercado mundial, que tendiam a ser compensados por um maior volume de exportações e por desvalorizações cambiais, cuja inflação resultante transferia para o conjunto da sociedade as perdas do setor agroexportador (no clássico mecanismo que Furtado denominou de "socialização das perdas”). Portanto, embora o ciclo do café tivesse propiciado uma relativa modernização da sociedade brasileira (urbanização, industrialização, formação de “novos grupos de pressão” etc.), não havia eliminado alguns dos típicos problemas estruturais de uma economia dependente: a extrema importância do “setor externo” da economia, a vulnerabilidade frente às oscilações cíclicas internacionais, a tendência ao desequilíbrio externo, a heterogeneidade tecnológica, a concentração de renda, o processo inflacionário etc.

A partir da crise de 1929, com a queda brusca do preço internacional do café - o que gerou graves restrições à capacidade de importar do país - e com a subseqüente política de defesa do setor cafeeiro empreendida pelo governo brasileiro, o autor assinala o começo de uma nova etapa na história econômica nacional, por ele

\footnotetext{
${ }^{62}$ Não à toa que, por conta dessas características, parte da historiografia brasileira vai denominar o café de uma "planta democrática". Veja-se, por exemplo, HANDELMANN, Henrique. História do Brasil. Rio de Janeiro: Nacional, 1931, p. 361 apud HOLANDA, Sérgio Buarque de. Raízes do Brasil. 26a. ed. São Paulo: Cia. das Letras, 2005, p.173.
} 
denominada de "deslocamento do centro dinâmico", isto é, o desvio de capitais do setor agroexportador para as atividades ligadas ao mercado interno, leia-se, a indústria. Se bem que Furtado, assim como Prebisch, não deixasse de assinalar os problemas inerentes à industrialização em um país com graves desequilíbrios econômicos, sociais e regionais, advindos de sua formação histórica, o autor via na intensificação desse processo, bem como numa ativa política de integração nacional, os ingredientes que poderiam conduzir o país a um desenvolvimento auto-sustentado, não mais orientado para e em função do mercado externo ${ }^{63}$.

Vê-se, portanto, que na abordagem histórico-estrutural de Furtado, o subdesenvolvimento surge como conseqüência, em primeiro lugar, da expansão do sistema capitalista global para regiões periféricas do planeta, e em segundo, de tendências e processos históricos engendrados nessas mesmas regiões, tais como a “involução econômica” ou a "socialização das perdas”, que contribuíam para reproduzir secularmente suas pobres estruturas econômicas e suas arcaicas formas de relação social. Esse enquadramento teórico-metodológico, que em Formação Econômica aparece apenas de forma implícita e restrita ao caso brasileiro - afinal tratava-se “de um esboço do processo histórico de formação da economia brasileira” - teria um tratamento mais sistemático e ampliado em seu próximo livro, o conjunto de ensaios reunidos em Desenvolvimento e Subdesenvolvimento.

Em certo sentido, nesta obra, Furtado generaliza para o conjunto dos países periféricos o esquema analítico empregado em sua obra anterior. Tratava-se, pois, de examinar a dinâmica do processo que conduzia ao subdesenvolvimento periférico vis-àvis o modo de funcionamento do capitalismo clássico verificado nas economias centrais. A mensagem central da obra - que, como veremos mais adiante, seria também um dos elementos constitutivos da teoria da dependência - era de que o subdesenvolvimento não representava uma etapa histórica comum a todos os países, uma espécie de

\footnotetext{
63 “A transformação estrutural mais importante que possivelmente ocorrerá no terceiro quartel do século XX será a redução progressiva da importância relativa do setor externo do processo de capitalização. Em outras palavras, as indústrias de bens de capital - particularmente as de equipamentos - terão de crescer com intensidade muito maior que o conjunto do setor industrial. Essa nova modificação estrutural, que já se anunciava claramente nos anos cinqüenta, tornará possível evitar que os efeitos das flutuações da capacidade para importar se concentrem no processo de capitalização. É essa uma condição essencial para que a política econômica se permita visar ao duplo objetivo de defesa do nível de emprego e do ritmo de crescimento. Somente assim alcançará o sistema econômico uma maior flexibilidade, e estará em condições de tirar maior vantagens do intercâmbio externo, pois poderá mais facilmente adaptar-se às modificações da procura que se exerce nos mercados internacionais”. FURTADO, Celso, op. cit., p.236.
} 
"passado" da formação histórica dos países atualmente desenvolvidos - tal como defendia, dentre outros, o economista americano W.W. Rostow ${ }^{64}$ - mas sim uma formação social singular, inédita na histórica do capitalismo, “[...] um processo particular, resultante da penetração de empresas capitalistas modernas em estruturas $\operatorname{arcaicas}, 65$.

Assim é que, argumenta Furtado, enquanto que o processo de desenvolvimento industrial europeu (e por extensão, nas colônias de povoamento do Novo Mundo) transcorrera, num primeiro momento, absorvendo completamente - quando havia - o setor pré-capitalista da economia, e numa segunda etapa, elevando substancialmente a produtividade e o padrão de vida dessas populações, bem diferentes foram as conseqüências da difusão do advento industrial para as regiões de antiga colonização. Nessas áreas, que se afiguram como o terceiro vetor da expansão econômica européia, gerou-se uma estrutura econômica e uma dinâmica social inteiramente distinta da verificada no processo histórico de desenvolvimento europeu ou norte-americano, A seguinte passagem, bastante conhecida, nos informa como teria se dado este processo:

A terceira linha de expansão industrial européia foi em direção às regiões já ocupadas, algumas delas densamente povoadas, com seus sistemas econômicos seculares, de variados tipos, mas todos de natureza pré-capitalista. $\mathrm{O}$ contato das vigorosas economias capitalistas com essas regiões de antiga colonização não se fez de maneira uniforme. Em alguns casos, o interesse limitou-se à abertura de linhas de comércio. Em outros houve, desde o início, o desejo de fomentar a produção de matérias-primas, cuja procura crescia nos centros industriais. O efeito do impacto da expansão capitalista sobre as estruturas arcaicas variou de região para região, ao sabor das circunstâncias locais, do tipo de penetração capitalista e da intensidade desta. Contudo, o resultante foi quase sempre a criação de estruturas híbridas, uma parte das quais tendia a comportar-se como um sistema capitalista, a outra, a manter-se dentro da estrutura pré-existente. Esse tipo de economia dualista constitui, especificamente, o fenômeno do subdesenvolvimento contemporâneo.

O subdesenvolvimento é, portanto, um processo histórico autônomo, e não uma etapa pela qual tenham, necessariamente, passado as economias que já alcançaram grau superior de desenvolvimento ${ }^{66}$.

\footnotetext{
${ }^{64}$ ROSTOW, Walt Whitman. Etapas do desenvolvimento econômico: um manifesto não comunista. $2^{\mathrm{a}}$. ed. Rio de Janeiro: Zahar, 1964

${ }^{65}$ FURTADO, Celso. Desenvolvimento e Subdesenvolvimento. $2^{\mathrm{a}}$. ed. Rio de Janeiro: Fundo de Cultura, 1963, p. 191

${ }^{66}$ Idem, Ibidem, p. 180, grifo nosso
} 
Portanto, ao expandir-se para a periferia do sistema, o capitalismo industrial europeu teria suscitado a formação de estruturas econômicas híbridas ou dualistas, com alguns setores voltados ao comércio exterior, de elevada produtividade, e o restante da economia comportando-se de acordo com a estrutura produtiva pré-capitalista existente. Essa dualidade básica das economias periféricas teria conferido a seu processo histórico de desenvolvimento um caráter singular, sem paralelo na história dos países do Velho Mundo $^{67}$. Nestes, diz Furtado, o dinamismo econômico era endógeno, vale dizer, resultava de transformações que se operavam no seio do próprio aparelho produtivo, de modo que o processo de industrialização resultou de uma combinação dinâmica e mais ou menos simultânea entre a evolução tecnológica e as condições históricas específicas desses países ${ }^{68}$. Com isso, pôde haver ao longo do tempo, aumento da produtividademédia do sistema econômico, elevação salarial dos trabalhadores e manutenção do ritmo de acumulação de capital. Já o processo de desenvolvimento das economias periféricas seguiria um padrão inteiramente distinto. Por serem essas economias o resultado do enxerto de modernas empresas capitalistas em uma estrutura social arcaica, Furtado assinala que nelas se operava um desequilíbrio ao nível dos fatores, isto é, a oferta de mão-de-obra (abundante) e de capital (escasso), não correspondiam à tecnologia que era absorvida pelo setor dinâmico da economia, precisamente porque esta tecnologia (intensiva em capital e poupadora de mão-de-obra) derivava de um "lento processo de decantação" de economias com elevado grau de industrialização. Assim, correlativamente à formação de setores tão avançados quanto a tecnologia gestada nas

67 Conforme observa Carlos Mallorquin, apesar da idéia central de Furtado de que os países subdesenvolvidos não iriam simplesmente repetir a história pretérita das sociedades industrializadas, ao utilizar expressões como "grau com relação as economias desenvolvidas”, ou “estágios do subdesenvolvimento", o autor flerta muitas vezes com uma concepção teleológica e etapista da história. Cf. MALLORQUIN, Carlos, op. cit., p. 122-143. Certamente esses vícios de linguagem retiram força de sua argumentação, mas não cremos que invalidem a tese principal do livro, sobretudo se pensarmos que os termos utilizados por Furtado, "grau" ou "estágio", referem-se antes ao nível de complexidade do sistema econômico (tamanho do setor de subsistência, existência de um mercado interno, nível de desenvolvimento tecnológico, grau de diversificação do aparelho produtivo etc.) do que o a etapas universais e constantes do desenvolvimento econômico.

${ }^{68}$ Resumidamente, as transformações se operaram da seguinte maneira: na medida em que a expansão do setor industrial ia tornando a oferta de mão-de-obra menos elástica, aumentando, portanto, os salários pagos aos trabalhadores, os avanços tecnológicos, poupando força de trabalho, possibilitavam os empresários manter suas taxas de lucro, o que por sua vez, conduzia a novas inversões que permitiam incorporar os trabalhadores desempregados pela utilização de técnicas produtivas mais avançadas, e assim por diante. Em trabalho posterior, embora o autor mantivesse essa mesma descrição a respeito do desenvolvimento capitalista do tipo “clássico”, ele atribuiria à luta dos trabalhadores uma importância ainda maior para o desencadeamento de todo este processo: “[...] é a atuação das classes trabalhadoras, no sentido de aumentar sua participação no produto, que cria as condições para o avanço da tecnologia. Este, por seu lado, permite que se mantenha uma elevada taxa de acumulação, sem embargo da inelasticidade da oferta de mão-de-obra.” FURTADO, Celso. Dialética do Desenvolvimento. Rio de Janeiro: Fundo de Cultura, 1964, p.64. 
nações industrializadas permitissem, surgiam, permaneciam ou renovavam-se as estruturas arcaicas típicas dos países subdesenvolvidos, como a existência de um anacrônico e tenaz setor de subsistência.

Cabe assinalar que, para Furtado, nem todos os países do pólo periférico estruturavam-se economicamente dessa mesma maneira. Em alguns deles, e o Brasil era o grande exemplo, em virtude dos motivos anteriormente mencionados (grande disposição de fatores de produção, monetização da economia, restrições no mercado internacional etc.), uma organização mais complexa do aparelho produtivo pôde surgir, com o aparecimento de um importante setor urbano-industrial ligado ao mercado interno. O que não significava, necessariamente, que a "procura externa” houvesse deixado ter um papel relevante na dinamização econômica: "Nas estruturas subdesenvolvidas mais complexas - onde já existe um núcleo industrial ligado ao mercado interno - podem surgir reações cumulativas, tendentes a provocar transformações estruturais no sistema. O fator dinâmico básico continua a ser a procura externa; a diferença está em que a ação desta é multiplicada internamente” ${ }^{69}$. Nesse sentido, tal como nas estruturas subdesenvolvidas "de grau inferior”, o processo de crescimento econômico permanecia basicamente induzido de fora para dentro, isto é, “o elemento dinâmico reside ainda na procura preexistente - formada, principalmente, por indução externa - e não nas inovações introduzidas nos processos produtivos, como ocorre nas economias industriais totalmente desenvolvidas”70. Portanto, uma estrutura econômico-social subdesenvolvida podia ser definida, nos termos de Furtado, “[...]como aquela em que a plena utilização do capital disponível não é condição suficiente para a completa absorção da força-de-trabalho, ao nível de produtividade correspondente à tecnologia que prevalece no setor dinâmico do sistema. É a heterogeneidade tecnológica entre setores ou departamentos de uma mesma economia que caracteriza o subdesenvolvimento" ${ }^{\text {71 }}$.

Sem embargo, a julgar pelas predições e anseios estruturalistas da primeira metade dos anos 1950, seria de se esperar que à medida que o processo de industrialização avançasse, esse heterogêneo arranjo do sistema produtivo desapareceria, isto é, as estruturas econômicas e sociais arcaicas seriam

\footnotetext{
${ }^{69}$ Idem, Ibidem, p. 189-190

${ }^{70}$ Idem, Ibidem, p. 191

${ }^{71}$ Idem, Ibidem, p. 195
} 
progressivamente eliminadas ou incorporadas pelo avanço do setor ligado ao mercado interno. Entretanto, essa visão otimista inicial dos autores cepalinos começava a ser substituída pela idéia de que o subdesenvolvimento não necessariamente se extinguiria apenas com o advento da industrialização. E a razão disso era bem simples. Uma vez que a industrialização periférica (substituição de importações) era movida pelo lado da demanda, isto é, induzida principalmente a partir da "procura preexistente" vinda de fora, e não pelo lado da oferta, os produtores nacionais, a fim de terem condições de competir com os produtores estrangeiros, seriam obrigados a utilizar as mesmas técnicas produtivas poupadoras de mão-de-obra que as utilizadas pelos concorrentes internacionais ${ }^{72}$, daí que

[...] a estrutura ocupacional do país [subdesenvolvido] se modifica com lentidão. O contingente da população afetada pelo desenvolvimento mantém-se reduzido, declinando muito devagar a importância relativa do setor cuja principal atividade é à produção para a subsistência. Explica-se, deste modo, que uma economia, onde a produção industrial já alcançou elevado grau de diversificação e tem uma participação no produto que pouco se distingue da observada em países desenvolvidos, apresente uma estrutura ocupacional tipicamente pré-capitalista e que a grande parte de sua população esteja alheia aos benefícios do desenvolvimento. ${ }^{73}$

Por demonstrar de forma inequívoca que o subdesenvolvimento não era apenas uma fase ou um estágio do processo civilizatório rumo ao desenvolvimento, mas sim uma configuração econômico-social insólita do capitalismo, com suas idiossincráticas estruturas internas e com uma trajetória histórica $\operatorname{impar}^{74}$, alguns atribuem a Furtado a “posição de reivindicar o crédito de ter sido o primeiro analista da dependência"75 ${ }^{\text {. Não }}$ obstante, e sem prejuízo da indiscutível importância de suas análises para o surgimento da escola dependentista, há pelo menos três formulações ou aspectos da obra furtadiana

\footnotetext{
${ }^{72}$ Alguns anos mais tarde, já munido de um instrumental teórico e de um discurso marcadamente dependentista, Furtado articularia essa argumentação com a idéia de uma dependência cultural, isto é, devido ao fato das classes sociais mais abastadas da periferia imitarem os padrões de consumo e de comportamento das elites dos países centrais, condicionando assim a heterogênea organização da estrutura produtiva local e os demais fenômenos associados (desequilíbrio na balança de pagamentos, desigualdade de renda etc.) . Cf. FURTADO, Celso. O mito do desenvolvimento econômico. São Paulo: Círculo do Livro, 1974, p.77-96

${ }_{74}^{73}$ FURTADO, Celso. Desenvolvimento e Subdesenvolvimento, op. cit, p. 192-193

${ }^{74}$ De forma paralela e simultânea, Paul Baran desenvolveria um raciocínio semelhante ao de Furtado, embora as conclusões que dele tirariam seriam bem mais radicais que as do economista brasileiro: " $\mathrm{O}$ estabelecimento de uma economia socialista planificada é condição essencial, e mesmo indispensável, para que os países subdesenvolvidos atinjam o progresso econômico e social”. BARAN, Paul. A economia política do desenvolvimento. $3^{\text {a. }}$. ed. Rio de Janeiro: Zahar, 1972, p. 355 (a primeira edição é de 1957).

${ }^{75}$ LOVE, Joseph, op. cit., p. 391.
} 
- pelo menos até aquele início dos anos 1960 - que, em nossa avaliação, impedem de atribuir ao economista brasileiro esta primazia.

Em primeiro lugar, ainda nas páginas que encerram Desenvolvimento $e$ Subdesenvolvimento, nas quais o autor reflete sobre a dinâmica e sobre os problemas da industrialização brasileira, Furtado dá a entender que a superação do subdesenvolvimento dependia meramente de um uso mais racional dos fatores e de uma distribuição mais equitativa das rendas e das terras, em resumo, era uma questão de incorporação das massas urbanas e rurais aos frutos do progresso. O autor não especifica, todavia, quais os requisitos políticos necessários para a realização desse verdadeiro projeto de transformação econômico-social ${ }^{76}$. E para a escola dependentista, a análise dessas condições era tão ou mais importante quanto a análise dos fatores eminentemente econômicos. Noutras palavras, era justamente o exame da estrutura de classes e das condições políticas da periferia, e não apenas dos fatores econômicos tomados isoladamente que, na acepção dependendista, poderiam revelar os obstáculos, os limites e as reais possibilidades para a realização das esperanças desenvolvimentistas. Ao fazê-lo, os pensadores desta escola demonstrariam a virtual inexistência de bases sociais e a existência de importantes barreiras políticas e institucionais para a concretização dessas realizações, isto é, por um lado, não existiriam atores coletivos interessados e ao mesmo tempo capazes de proporcionar essa verdadeira sublevação social, e por outro, haveria uma determinada estrutura de dominação que impedia ou restringia a distribuição dos frutos do desenvolvimento ao conjunto da população.

Em segundo lugar, no modelo analítico furtadiano, uma das características centrais do subdesenvolvimento é o arcaísmo social, cultural, político e econômico de certas regiões ou grupos sociais (no caso brasileiro, o Nordeste e as oligarquias latifundiárias, respectivamente), que atravancam o crescimento econômico do país, dado a utilização de técnicas produtivas rudimentares, e impedem a formação de um mercado interno de proporções mais ampliadas, dado o baixíssimo salário (ao nível de

\footnotetext{
${ }^{76}$ Se bem que Furtado preencha essa lacuna em suas próximas publicações - especialmente em A PréRevolução Brasileira (1962) e em Dialética do Desenvolvimento (1964) - não é difícil perceber que um dos sustentáculos políticos do projeto nacional-desenvolvimentista do autor, assim como de toda corrente ideológica homônima, era a burguesia industrial, com sua suposta função modernizadora e sua pretensa vocação autônoma. Ora, a rejeição a este postulado seria um dos principais elementos constitutivos da escola da dependência e, em realidade, um dos poucos pontos em comum entre seus diversos autores.
} 
subsistência) pago aos trabalhadores. Nesse modelo, também chamado de dualista ${ }^{77}$, há uma pronunciada divisão da economia e sociedade periféricas em dois polarizados setores: de um lado, o “tradicional” setor arcaico, de origem pré-capitalista, de reduzida utilização de técnicas modernas de produção e de organização, vinculado ou subordinado ao mercado externo, e cujas elites eram politicamente reacionárias e pouco afeitas ao progresso social; de outro, o chamado setor moderno da economia, assentado na indústria, nos ganhos de produtividade, na produção para o mercado interno e cujas camadas dirigentes eram muito mais "progressistas", arrojadas e simpáticas à idéia de um desenvolvimento nacionalmente orientado. Tratava-se, pois, de setores bem delimitados, com dinâmicas distintas e com interesses antagônicos. Mais ainda, sob esta ótica, a sobrevivência do primeiro setor era um empecilho para a plena constituição do segundo, uma vez que a reduzida massa salarial que aquele proporcionava a seus trabalhadores, impedia que se formasse um verdadeiro mercado consumidor de massas, condição sine qua non para a expansão do setor industrial, e conseqüentemente, para o próprio desenvolvimento. Na matriz teórica da dependência, por seu turno, essa clara relação antagônica que Furtado estabelece entre esses dois setores, tornar-se-á menos aguda, quando não, simplesmente deixará de existir. Do ponto de vista socioeconômico, sustentarão alguns de seus autores, se era verdade que a remuneração dos trabalhadores do campo mal permitia sua sobrevivência, também era verdade que esse baixo piso salarial fornecia as bases do custo de mão-de-obra para todo o sistema produtivo, inclusive para o setor industrial, favorecendo, por essa via, a acumulação capitalista na indústria. Ainda que Furtado tivesse bastante ciência desse fenômeno - na verdade, ele fora um dos primeiros a registrá-lo - sua conclusão era de que isso representava uma reminiscência pré-capitalista, cuja sobrevivência, no limite, prejudicaria a expansão industrial, ao invés de, como fariam alguns dos interpretes da dependência, considerá-la absolutamente funcional à formação e ao acúmulo de capital nesse setor. Nesse sentido, argumentarão os autores dependentistas, não havia uma relação dicotômica entre um setor atrasado de natureza e comportamento pré-capitalistas, em contraponto a outro de feições modernas e capitalistas; ambos possuíam um modo de produção inteiramente

\footnotetext{
77 Embora a teoria da dependência, especialmente sua versão ortodoxa, fizesse cerradas críticas à concepção dualista dos autores cepalinos, essa postura não era uma exclusividade sua, ao contrário, a partir dos anos 1960 uma extensa literatura, não necessariamente ligada à esta escola de pensamento, surgiria para negar ou relativizar o caráter dual do capitalismo brasileiro e latino-americano. Nesse particular, duas obras destacam-se: STAVENHAGEN, Rodolfo. "Sete Teses Equivocadas sobre a América Latina”. In: DURAND, João Carlos Garcia. (Org.) Sociologia de desenvolvimento. Rio de Janeiro: Zahar, 1969; e também OLIVEIRA, Francisco de. "Economia Brasileira: Crítica à Razão Dualista”, Estudos Cebrap, vol. 2, São Paulo, 1972, p. 4-82
} 
capitalista. Seguindo essa linha de raciocínio, também rejeitarão a tese de uma profunda cisão política entre os principais estratos burgueses. Tanto a "moderna” burguesia industrial, quanto as "atrasadas" oligarquias rurais seriam avessas ao populismo, às agitações operárias e estudantis e a uma maior divisão dos lucros com os trabalhadores; por outro lado, ambas seriam favoráveis à conservação da ordem política, à participação estrangeira na economia e ao autoritarismo.

Por fim, para Furtado, e para os partidários do nacional-desenvolvimentismo de uma maneira geral, industrialização e autonomia nacional eram processos que se coadunavam, ou melhor, a obtenção do segundo objetivo era uma conseqüência necessária da consecução do primeiro. Nas palavras de Furtado, ainda em Desenvolvimento e Subdesenvolvimento: “Os centros de decisão que se apóiam nas indústrias ligadas ao mercado interno gozam, por definição, de elevado grau de

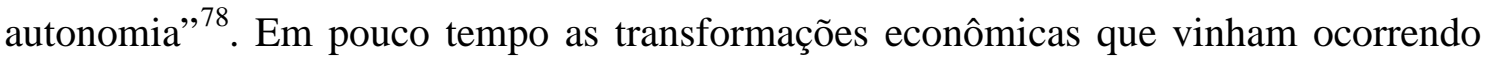
no Brasil, e logo em seguida os diversos estudos sobre a nova etapa do desenvolvimento brasileiro, iriam demonstrar o equívoco desta afirmação. Conforme as empresas multinacionais iam se instalando nos setores ligados ao mercado doméstico - e, eventualmente, se tornando o principal pólo da economia brasileira -, mais evidente ficava que o "deslocamento do eixo dinâmico" e a "a transferência dos centros de decisão para dentro do país” não eram fenômenos correlatos. O equívoco fundamental da interpretação de Furtado e dos autores estruturalistas estava em presumir que a industrialização na periferia provocaria transformações estruturais análogas às produzidas nas economias centrais, quando as condições materiais na época em que estes se industrializaram eram assaz distintas: as exigências em termos de acúmulo de capital eram ainda relativamente baixas, gozavam de um relativamente amplo mercado interno (e, em alguns casos, também o externo) e ainda não havia propriamente grandes corporações transnacionais que dominassem e condicionassem a organização do mercado mundial. Na ausência dessas condições e com uma burguesia nacional que em nada se parecia com suas congêneres européias ou americanas, defenderá a escola dependendista, o aprofundamento do processo industrializante não implicaria no fim da secular heteronímia política do país, nem tampouco na redução de suas gigantescas contradições sociais, ao contrário, ensejaria novas situações de dependência e novas formas de exclusão social.

\footnotetext{
${ }^{78}$ FURTADO, Celso, Desenvolvimento e Subdesenvolvimento, op. cit., p. 245
} 
No geral, essas facetas do pensamento furtadiano expõem uma deficiência que está na raiz do próprio modelo analítico estruturalista de seu período inicial: não se examina em profundidade, ou o faz de maneira muito subordinada à esfera econômica, os condicionantes sócio-políticos do desenvolvimento. Em outras palavras, os autores cepalinos atribuíam muito mais peso aos requisitos econômicos necessários ao avanço da força produtiva, do que as exigências em termos de relações de produção necessárias a essas mudanças. É por isso que a industrialização, na medida em que por meio dela permitir-se-ia elevar a produtividade da economia, modernizar a estrutura produtiva e reduzir a dependência econômica externa, é vista como o passaporte para o desenvolvimento de países pobres e agrários, como a maioria dos países latinoamericanos daquele período. No entanto, não se problematiza adequadamente a questão da estrutura e da luta de classes, canal pelo qual as transformações econômicas estruturais necessariamente “passam”, nem se questionam as formas de exploração inerentes à essa forma de organização produtiva, o que fará muitos de seus críticos a enxergar na Cepal um instrumento de classe de defesa dos interesses da burguesia industrial $^{79}$. Dessa maneira, conforme muitos argumentariam, o pensamento estruturalista cepalino,

[...] postula ideologicamente a reprodução das relações capitalistas de produção nas formações sociais da periferia. Ainda que uma forma implícita, define, pois, a priori, os tipos de relação que prevalecerão entre as diferentes classes e grupos e, portanto, deixa de examinar as características específicas que assumem essas relações no interior das formações periféricas, e entre estas e as formações avançadas do sistema capitalista mundial. Por outro lado, desconhece a existência de uma relação básica de exploração entre capital e trabalho, tanto na periferia como a nível internacional, assim como do condicionamento que ela virtualmente impõe ao desenvolvimento periférico ${ }^{80}$.

\footnotetext{
79 "Representando em grande parte essa burguesia industrial, a Cepal procurou saídas que não afetassem a questão agrária e que permitissem expropriar recursos do latifúndio com mecanismos de intervenção estatal, sem chegar ao enfrentamento. Um desses mecanismos foi a inflação, que permitia uma política de preços relativos favorável ao setor industrial”. SANTOS, Theotônio dos. A teoria da dependência: balanços e perspectivas. Rio de Janeiro: Civilização Brasileira, 2000, p. 84-85. Se é verdade que as proposições iniciais recomendadas pela escola cepalina favoreciam o desenvolvimento industrial periférico (o que vai uma grande distância de caracterizá-la como um "instrumento de classe" do empresariado industrial), de forma alguma se pode afirmar que seus autores desconsideravam o problema da concentrada estrutura fundiária dos países da região, e em especial do Brasil. Ao contrário, muito antes da Cepal entrar em seu período de "reformulação crítica" nos anos sessenta, suas análises já diagnosticavam a reforma agrária e a modernização do campo como algumas das condições essenciais para o desenvolvimento.

${ }^{80}$ RODRIGUEZ, Octavio, op. cit., p. 265.
} 
Explorando ao máximo essas insuficiências teóricas e metodológicas, porém, simultaneamente, valendo-se de muitas das descobertas e ensinamentos estruturalistas, todo um novo conjunto de análises sobre o desenvolvimento periférico emergirá a parir dos anos 1960. A força e influência dessas idéias serão tanto maiores quanto mais as transformações políticas, econômicas e sociais "confirmavam” suas análises e, inversamente, contradiziam as previsões dos autores da escola cepalina. Ao final daquela década, esse conjunto de análises estará reunido numa nova matriz teórica de diferentes tonalidades, que, em grande medida, substituirá o estruturalismo, tanto na capacidade de explicar e prever os fenômenos histórico-sociais, quanto na preferência dos pesquisadores e intelectuais de esquerda. 


\section{Crise do estruturalismo e emergência da teoria da dependência}

Ao final dos anos cinqüenta e começo dos sessenta do século passado, as idéias e concepções da escola estruturalista estavam no auge de sua influência e popularidade no meio acadêmico latino-americano, ao mesmo tempo em que eram reconhecidas e saudadas em alguns circuitos intelectuais do Norte, ao ponto de um eminente economista britânico, um dos pioneiros da development economics, sentenciar: “ 'the writings of the Latin American structuralism' could provide the basis for the

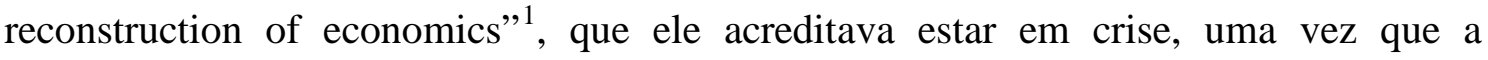
disciplina parecia ser incapaz de proporcionar soluções aos inúmeros problemas e desafios enfrentados pelos países do Terceiro Mundo. Embora não se possa afirmar que essa aspiração tenha realmente se efetivado, isto é, o estruturalismo jamais fora seriamente considerado pela ciência econômica convencional ou propriamente retratado nos principais manuais e livros-textos de economia - os quais, quando muito, atêm-se a determinados aspectos dessa escola de pensamento, como a deterioração dos termos de intercâmbio ou a tese da inflação estrutural - as idéias e proposições da Cepal gozaram de certo prestígio entre cientistas sociais norte-americanos e europeus (sobretudo os de filiação keynesiana) naquele breve intervalo entre o descrédito da ortodoxia liberal no pós-45 e a radicalização política (pelo lado da esquerda) e a ascensão monetarista (pela direita) a partir de meados dos anos 1960.

No campo político-ideológico, as teses estruturalistas eram igualmente populares e abraçadas por diversos grupos e forças nacionalistas da região. No contexto brasileiro, a Cepal, juntamente com o Instituto Superior de Estudos Brasileiros - ISEB e, a despeito de suas oscilações programáticas, o Partido Comunista Brasileiro - PCB ${ }^{2}$, ajudaram a forjar e a difundir o movimento nacional-desenvolvimentista. Se bem que a interpretação da Cepal fosse tecnicamente mais rigorosa e precisa, e, pelos motivos

\footnotetext{
${ }^{1}$ SEERS, Dudley. "The limitation of the special case". Bulletin of the Oxford University Institute of Economics \& Statistics, Oxford University, vol. 25, n²2, p. 98, may 1963 apud KAY, Cristóbal, op. cit., p. 2

${ }^{2}$ Sobre as idas e vindas programáticas do "partidão”, veja-se BRANDÃO, Gildo Marçal. A esquerda positiva: as duas almas do Partido Comunista - 1920/1964. São Paulo: Editora Hucitec, 1997.
} 
anteriormente citados $^{3}$, politicamente menos inflamada, eram nítidas as afinidades com a interpretação dos comunistas ${ }^{4}$ e dos isebianos ${ }^{5}$, especialmente no que se refere a três aspectos normativos: a defesa do processo de industrialização nacional como condição necessária (e num primeiro momento, suficiente) para o desenvolvimento; a necessidade do Estado de promover e tutelar as transformações econômicas e sociais, bem como a de arbitrar os conflitos emergentes na sociedade ("O Estado como demiurgo da sociedade”); e, contra os interesses da aristocracia agrário-exportadora e das grandes potências imperialistas, que eram refratárias à mudança da tradicional estrutura produtiva e social, a necessidade de formação de um amplo arco de alianças envolvendo trabalhadores urbanos, setores médio-urbanos, burocracia estatal e burguesia nacional - que desse sustentação política para as medidas de incentivo à indústria e para as necessárias reformas sociais e institucionais (trata-se, grosso modo, da idéia de revolução nacional democrático-burguesa do $\mathrm{PCB}^{6}$ ).

\footnotetext{
${ }^{3}$ Vide nota 44 do capítulo anterior.

4 "Não obstante as diferenças de instrumentais teóricos, de linguagem e de projetos políticos, é possível estabelecer um paralelismo entre a análise dessa corrente [socialista do PCB] e a cepalina, que as tornava próximas no que diz respeito à capacidade de interpretar a dinâmica econômica. A análise cepalina continha a idéia do processo substitutivo de importações, que os socialistas pareciam aceitar - sem, contudo, dar-lhe grande importância. Afora este aspecto, ambas continham elementos analíticos dirigidos à identificação de "tendências" de médio e longo prazos que estariam obstruindo o processo de crescimento. Para a Cepal, as "tendências" à inflação, ao desemprego, à concentração de renda, ao estrangulamento externo etc., advinham de fatores estruturais de caráter "interno" e "externo", cabendo ao Estado planejar a economia e executar reformas institucionais para viabilizar o desenvolvimento. Para a corrente socialista, o desenvolvimento das forças produtivas era, a médio e longo prazos, obstruído por uma "contradição interna" (a estrutura agrária) e por uma contradição externa (a interferência do imperialismo), cabendo a realização de reformas de base e a transição para um "capitalismo de Estado", ou seja, uma economia planificada com maciça participação de investimentos estatais e capaz de controlar o comércio exterior e contrapor-se aos interesses imperialistas.” BIESLCHOWSKY, Ricardo, op. cit., p. 426

5 “[...] o ISEB e a CEPAL salientavam, em primeiro lugar, que, a partir da aceleração do desenvolvimento industrial nos anos 30, a sociedade latino-americana deixava de ter uma organização bipolar simples, baseada em uma oligarquia dominante e uma massa rural, e passava por um processo de diferenciação que dava origem a classes médias burguesas e burocráticas modernas, cabendo a elas um papel-chave na liderança do desenvolvimento. [...]. Em segundo lugar, os intelectuais dos dois grupos verificavam que o Estado, através de seus políticos e técnicos, estava desempenhando um papel estratégico no desenvolvimento e viam esse fato de forma positiva. O Estado devia, principalmente, proteger a indústria nacional infante contra a concorrência estrangeira, reservando seu mercado interno para essa indústria daí a tese de que o desenvolvimento deve ocorrer pela substituição de importações. [...] Para o ISEB principalmente, o desenvolvimento econômico envolve sempre revolução nacional — ou, como dizia Celso Furtado, "a transferência dos centros de decisão para dentro do país”. E, mais amplamente, envolve revolução capitalista. É a partir daí que se viabiliza a associação entre o empresário industrial, que é o agente por excelência do desenvolvimento, e os políticos e técnicos do governo, a quem cabe a coordenação do processo." BRESSER-PEREIRA, Luiz Carlos. "Do Iseb e da Cepal à Teoria da Dependência”, op. cit., p. 209-210.

${ }^{6}$ Pode-se assim resumir esta idéia:“[...] a sociedade brasileira da primeira metade do século atual [XX] é tida como semicolonial e semifeudal, sob o domínio do latifúndio e do imperialismo, resistindo ao avanço das forças produtivas e ao desenvolvimento da nação, reinvindicados pela burguesia industrial e pelo grosso da população brasileira. Portanto, o caminho para o socialismo no Brasil - a grande meta a ser
} 
Essas idéias serviram de suporte teórico e ideológico ao projeto nacionaldesenvolvimentista dos governos populistas da região, especialmente no Brasil, onde Celso Furtado, que vinha ocupando um papel de destaque desde o governo Juscelino Kubitschek na formulação e implementação de políticas públicas, defendia com entusiasmo o papel civilizatório que a modernização da economia brasileira proporcionaria: “[...] a industrialização não era apenas um meio de utilizar mão-de-obra redundante, mas essencialmente o instrumento que estava cimentando a nacionalidade. Já não se tratava de discutir sua oportunidade e conveniência, e sim de partir dela para liberar o país dos resquícios do passado colonial”7 . Ou ainda: "O Brasil está repetindo, até certo ponto, a experiência do Japão em décadas anteriores: a conquista da autodeterminação no plano econômico, ainda em uma fase caracterizada por um nível

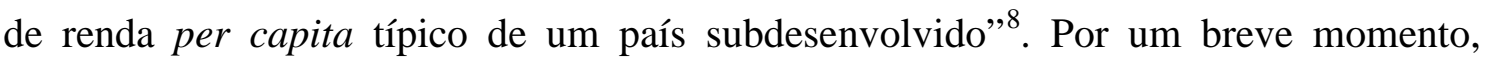
durante o otimismo nacional que embalou parte do governo JK, pensava-se, e parecia-se de fato, que com o amadurecimento do processo industrializante que o país vivenciava há pelo menos 30 anos, finalmente conseguiríamos sobrepujar a barreira que separa o subdesenvolvimento do desenvolvimento; finalmente o país iria constituir-se como uma Nação, na integral acepção da palavra, isto é, como uma sociedade economicamente próspera e socialmente justa, dotada de autodeterminação e livre das anacrônicas reminiscências coloniais. Industrialização e fundação das bases nacionais, ou em outros termos, independência econômica e integração social, eram, pois, o corolário de um mesmo processo de desenvolvimento.

Pois bem, não demorou muito para esse quadro alterar-se profundamente. À medida que os anos foram se passando e as promessas civilizatórias não foram sendo cumpridas, ao contrário, deteriorava-se a situação econômica do país e degradava-se a condição de vida de milhões de brasileiros, claro ficava que o modelo analítico que sustentara todo esse processo possuía graves falhas em algumas de suas premissas mais elementares. O mais flagrante dos problemas era que, com a industrialização, parecia estar se agravando o problema da pobreza e do desemprego para a maior parcela da sociedade. O drama social de milhões de pessoas nos principais centros urbanos do país

alcançada segundo os adeptos desse modelo - passava pela revolução nacional e democrática, que eliminaria os restos feudais, libertaria o grosso da população brasileira da miséria e opressão do latifúndio, expulsaria o imperialismo e, finalmente, estabeleceria uma sociedade democrática”. MANTEGA, Guido. A Economia Política Brasileira. 8a. ed. Petrópolis: Vozes, 1995, p. 158.

${ }^{7}$ FURTADO, Celso. “A fantasia organizada”, op. cit., p. 166-167, grifo nosso.

${ }^{8}$ Idem. A Pré-Revolução Brasileira. Rio de Janeiro: Fundo de Cultura, 1962, p. 9 
e a pauperização dos camponeses no campo eram as facetas mais visíveis, porém não as únicas, dos desafios postos ao pensamento estruturalista naquele começo da década de 1960. De fato, desde meados do decênio anterior uma série de eventos históricos e transformações econômico-sociais que transcorriam no Brasil e no mundo vinham contribuindo para fazer água no movimento nacional-desenvolvimentista, em geral, e no pensamento estruturalista em particular.

Primeiramente, do ponto de vista dos fenômenos econômicos, a despeito da modernização da estrutura produtiva brasileira estar se realizando com relativo êxito, tendo o país logrado constituir um amplo e diversificado setor industrial em um espaço de tempo relativamente curto, velhas dificuldades continuavam (ou voltavam) a assombrar os caminhos do desenvolvimento nacional, tais como o baixo crescimento econômico ${ }^{9}$, os constantes déficits comerciais ${ }^{10}$, o crescimento da dívida externa ${ }^{11}$, os elevados índices de inflação ${ }^{12}$, dentre outros. A conjuntura de desaceleração econômica e crise monetário-financeira do inicio dos anos 1960, potencializada por uma baixa internacional dos preços dos principais produtos brasileiros de exportação, dentre eles o café $^{13}$, fez reaparecer ou se agravar alguns dos conhecidos problemas do antigo sistema produtivo primário-exportador brasileiro (dificuldades essas que puderam ser parcialmente atenuadas ou contornadas no decênio anterior, em virtude das altas taxas de crescimento daquele período). Daí porque que a industrialização, ao invés de eliminar ou reduzir a dependência tecnológica e financeira em relação aos grandes centros capitalistas internacionais, havia, senão aumentado, lhes dado novos e graves contornos $^{14}$.

\footnotetext{
${ }^{9}$ Segundo dados da Cepal, após o crescimento do PIB brasileiro saltar de 3,3\% para 10,5\% entre 1956 e 1961, novamente o nível de atividade econômica no país iria retrair-se, caindo a 4,6\% em 1962 e "estagnando-se" em 1,6\% em 1963.

${ }^{10}$ De acordo com dados do Instituo de Pesquisas Econômicas e Aplicadas - IPEA, entre 1957 e 1964 a balança comercial brasileira registrou déficit em todos os anos, exceto em 1961, ano que entra em vigor a famosa instrução 204 da Superintendência da Moeda e do Crédito - Sumoc (espécie de Banco Central da época), aliviando momentaneamente a situação deficitária do saldo comercial do país.

${ }^{11}$ Segundo dados do Banco Central, em seis anos, de 1957 a 1963, a dívida externa brasileira aumentou em $45 \%$

${ }^{12}$ Pelo índice IPC da FIPE, a inflação nunca esteve abaixo dos $10 \%$ durante os anos 1950 e dispararia no começo dos anos 1960, atingindo 44\% em 1961, 62\% em 1962 e 81\% em 1963.

${ }^{13}$ O preço internacional do café cairia constantemente entre 1956 e 1963, atingido no fim do período citado pouco mais da metade do valor do período inicial. Fonte: Montevideo-Oxford Latin American Economic History Data Base - MOxLAD.

${ }^{14}$ No começo da década de 1960, Prebisch constatava perplexo às conseqüências não-previstas da industrialização latino-americana: "Continua sendo um paradoxo que a industrialização, ao invés de ajudar a amortecer bastante o impacto interno das flutuações externas, esteja nos trazendo um novo e desconhecido tipo de vulnerabilidade externa". PREBISCH, Raúl. "Economic Development or Monetary
} 
Por outro lado, paralelamente à crise ou esgotamento da fase denominada de substituição fácil de importações, importantes transformações que ocorriam na estrutura e organização do sistema capitalista a nível mundial, iriam modificar aquele tradicional esquema da divisão internacional do trabalho, tão criticado pela escola estruturalista. A partir de então, num processo mais ou menos contínuo que se estenderia pelas próximas décadas e se intensificaria a partir dos anos 1990, com a chamada globalização econômico-financeira, as grandes unidades capitalistas de produção (à época, denominadas genericamente de transnacionais) passariam cada vez mais a operar e a competir numa escala global, internacionalizando com isso a produção industrial. Em suma, o imperialismo não seria mais um empecilho à industrialização periférica - como sustentavam os autores estruturalistas e como, de fato, havia sido a tônica do capitalismo até aquele momento - ao contrário, o capital financeiro mundial, as grandes corporações multinacionais, os poderosos trustes e cartéis etc., seriam dali em diante um importante agente na modernização econômica dos países do Terceiro Mundo, particularmente de seus setores tecnologicamente mais avançados e/ou mais intensivos em capital, como o automobilístico por exemplo. E o Brasil talvez tenha sido um dos primeiros países periféricos no qual essa nova dinâmica capitalista se fez atuante. Paradoxalmente, foi ainda no auge do ciclo ideológico do nacionaldesenvolvimentismo, isto é, no governo Juscelino Kubitscheck, com seu ambicioso plano “50 anos em 5" - que, dentre outras coisas, favoreceria os investimentos externos no setor industrial - que se tem início à maciça entrada de capitais estrangeiros no país. Se por um lado essa política de desenvolvimento propiciou os altos índices de crescimento verificados no período e consolidou definitivamente a vocação industrial do país $^{15}$, por outro, ela levou à desnacionalização de setores estratégicos da cadeia produtiva, a um crescente processo inflacionário - e aos demais problemas econômicos anteriormente citados - e, até mesmo, ao tensionamento político que afetaria de maneira decisiva os governos seguintes.

Stability: A False Dilemma”. Economic Bulletin for Latin America 6, n ${ }^{\circ}$, mar 1961, p.5 apud LOVE, Joseph, op. cit., p.431.

15 "Dizemos que nesse período de cinco anos [1956-1961] se consolidou o desenvolvimento industrial brasileiro porque, depois do extraordinário surto industrial ocorrido nele, as oposições e as dúvidas de caráter fundamentalmente ideológico quanto às possibilidades de industrialização do Brasil desapareceram. A crença na vocação agrícola do Brasil perdeu qualquer substância". BRESSERPEREIRA, Luiz Carlos. Desenvolvimento e Crise no Brasil. 5a. ed., São Paulo: Editora 34, 2003, p. 59, grifo nosso. 
Em segundo lugar, dado o baixo dinamismo da economia brasileira no pósgoverno JK, crescia o exército de mão-de-obra de reserva que, aliado aos elevados índices de natalidade, à lenta transformação da agricultura (“expulsando”, com isso, numerosas populações do campo paras as cidades) e a um processo migratório interno sem precedentes na história do país, contribuiriam para dar dimensões dramáticas ao fenômeno da marginalidade urbana. Se nos anos de elevado crescimento econômico ainda não era de todo evidente que o setor industrial seria incapaz de absorver os enormes contingentes populacionais que se aglomeravam nos grandes centros metropolitanos, durante o período de desaceleração, esse fato se mostraria a olho nu ${ }^{16}$. Com efeito, enquanto a população brasileira crescia a um ritmo impressionante e tornava-se pela primeira vez majoritariamente urbana, o aclamado setor “moderno" da economia não conseguia absorver mais do que $14 \%$ da população economicamente ativa, proporção três vezes menor do que o empregado pelo chamado setor “primitivo”17. A julgar pelo reduzido contingente de mão-de-obra empregada, o setor industrial contribuía para aumentar, ao invés de diminuir, a parcela da população vivendo às margens do desenvolvimento ${ }^{18}$. Some-se isso à elevada inflação do período - que corroía a renda real da população, especialmente de suas camadas mais pobres e “desprotegidas” - e as péssimas condições de vida no subúrbio das principais cidades brasileiras, e tem-se um quadro de agudização das tensões sociais e de descrença generalizada no âmbito das esquerdas quanto às conseqüências do processo industrializante.

Por fim, à crise econômica e social dos anos 1960 iria juntar-se, e contribuir para sua evolução, a grave crise política dos governos Quadros e Goulart. Os motivos que levaram à instabilidade institucional e às agitações sócio-políticas deste período

\footnotetext{
${ }^{16}$ A própria Cepal já atentara para esse problema na segunda metade dos anos 1950, mas seria apenas no decênio seguinte que a incapacidade de absorver o excesso de mão-de-obra se converteria num problema "estrutural" ou numa "insuficiência dinâmica" da industrialização periférica. Sobre isso, veja-se FURTADO, Celso. Desenvolvimento e Subdesenvolvimento, op. cit., p.163-270; e também PREBISCH, Raúl. Hacia una dinámica del desarrollo latinoamericano. México, DF: Fondo de Cultura Económica, 1963, p.27-52.

${ }^{17}$ Cf. PINTO, Anibal. "Naturaleza e implicaciones de la 'heterogeneidad estructural' de la América Latina.”. In: CEPAL. Cincuenta años de pensamiento en la Cepal - Textos Seleccionados. Volumen II. Santiago: Fundo de Cultura Económica, 1998 p. 566.

${ }^{18}$ Não se têm, salvo engano, estatísticas nacionais e oficiais sobre desemprego para aquele período. No entanto, alguns dados dão conta da magnitude do problema social aludido: "[...] durante os anos 1960, apesar do extraordinário desenvolvimento industrial, a indústria de transformação teve o número de seus empregados elevado a uma taxa anual de apenas $3 \%$, o que se explica pelo uso de tecnologia capitalintensiva, economizadora de mão-de-obra. Esse crescimento de 3\%, quando comparado aos 3,5\% de crescimento da população ativa e aos $5,4 \%$ de crescimento da população urbana, revelou-se claramente insuficiente”. BRESSER-PEREIRA, Luiz Carlos, op. cit., p. 67.
} 
envolvem uma constelação de fatores: das referidas dificuldades econômicas, ao contexto ideológico internacional de Guerra Fria, da notória falta de habilidade política dos supracitados presidentes para enfrentar as adversidades, ao arranjo políticoinstitucional propício à paralisia e ao conflito etc. Não nos compete aqui entrar no detalhes, nem na relação de causalidade entre todos esses fatores. Sem embargo, sob um ponto de vista mais geral, essa crise expressava e dava vazão ao próprio colapso do modelo político que sustentara e norteara as ações do Estado desenvolvimentista durante toda a década de 1950. A unidade do assim chamado pacto populista, isto é, a aliança entre operários urbanos, setores da classe média e a burguesia industrial, sob o guarda-chuva de um Estado nacionalista e desenvolvimentista, apresentava claros sinais de esgotamento e não parecia mais ser capaz de soldar os objetivos e interesses conflitantes de seus membros, deixando transparecer com isso as naturais contradições que resultam da união entre capital e trabalho. Assim, conforme assinala Guido Mantega:

Não havia propriamente uma contestação das principais bandeiras do desenvolvimentismo, que pregava a industrialização, a criação da infra-estrutura ou a modernização do País. Havia sim objeções quanto à liberdade de manifestações populares e às reivindicações salariais que se multiplicavam nesse período. Vários segmentos das classes dominantes e mesmo da classe média estavam descontentes com a mobilização e a crescente capacidade de reivindicação das classes populares, que aumentavam com a ineficiência dos governos e a deterioração do desempenho econômico.

Com a economia quase estagnada e dificuldades nas contas externas, ficava cada vez mais difícil conciliar a manutenção das taxas de lucratividade, como pretendia a burguesia, com os aumentos salariais exigidos pelos trabalhadores. Os segmentos da burguesia que prosperaram com o desenvolvimentismo estavam receosos com as atitudes muitas vezes inesperadas dos líderes populistas, como Jânio Quadros ou João Goulart, e perdiam o sono com as ligas camponesas e o crescimento do movimento popular. ${ }^{19}$

A rigor, o processo de implosão da aliança tácita ou consentida entre trabalhadores e "burguesia nacional" se inicia ainda no governo JK, quando, a partir de uma série de "fatos históricos novos" ${ }^{20}$, como o recrudescimento da atividade sindical ou a Revolução Cubana - fatores que atormentam o empresariado local e trazem à tona

\footnotetext{
${ }^{19}$ MANTEGA, Guido. Teoria da dependência revisitada: um balanço crítico, op. cit., p.8-9.

${ }^{20}$ Para uma síntese desses "fatos novos", alguns dos quais anteriormente expostos, vide BRESSERPEREIRA, Luiz Carlos. "Seis interpretações sobre o Brasil”. Dados, Rio de Janeiro, 25(3), 1982, p. 287288. Para uma exposição mais detalhada, veja-se BRESSER-PEREIRA, Luiz Carlos. Desenvolvimento $e$ crise no Brasil, op. cit., p. 99-122.
} 
o temor da subversão popular - elimina-se, ou torna relativamente sem importância, o conflito de interesses existente entre os diversos estratos da burguesia, particularmente os da velha oligarquia agroexportadora e os do empresariado industrial, ao mesmo tempo em que colocava sob forte suspeição o papel dos trabalhadores no projeto de desenvolvimento nacional. Em suma, neste cenário de deterioração econômica e radicalização política, o verdadeiro obstáculo da burguesia industrial para a dinamização da acumulação capitalista era o operariado e sua sanha reinvindicatóriorevolucionária, e não as anacrônicas - e já um tanto debilitadas - oligarquias regionais ou as empresas transnacionais, com os quais buscarão, então, aliar-se ou associar-se. Sob um ângulo estritamente econômico (e de curto prazo, que era o que de fato interessava aos empresários), o projeto representado pela aliança com o imperialismo oferecia maiores possibilidades de lucros e não colocava em risco a propriedade privada, ainda que isso se desse à custa de sua hegemonia política; ao passo que a união com os trabalhadores e com a esquerda, além de não oferecer ganhos imediatos no curto prazo (ao contrário, dado a política econômica redistributiva do governo Jango: tributação sobre os lucros, progressividade do imposto de renda etc.), trazia consigo o iminente perigo da revolução socialista. Desta maneira, abriu-se caminho para que, com o acirramento das tensões sociais e o conseqüente imobilismo político, fosse liquidado o pacto populista e instaurado um novo regime político, que eliminaria de uma vez por todas a participação popular no consórcio de poder ${ }^{21}$.

O golpe militar de abril de 1964 representou, portanto, a morte do movimento nacional-desenvolvimentista (mas não do desenvolvimentismo em si mesmo, entendose isso como a ideologia que pretendia acelerar o processo de industrialização mediante a intervenção e o planejamento estatais) num duplo sentido: ao afastar da vida política do país suas principais lideranças e cabeças ${ }^{22}$, e ao invalidar algumas das premissas

\footnotetext{
${ }^{21}$ Não queremos dizer com isso, obviamente, que o regime autoritário era uma conseqüência inevitável do esgotamento do "pacto populista", ou, do ponto de vista econômico, era um regime político necessário ao novo modelo de desenvolvimento - ancorado no capital estrangeiro e nas empresas multinacionais que começava a entrar em vigor naquele começo da década de 1960 (idéia essa, aliás, amplamente compartilhada pelos autores da escola dependentista). Apenas quer se apontar alguns fatores que tiveram importante contribuição para a subida dos militares ao poder, mas que não guardam com ele uma relação "mecânica” de causalidade. Desnecessário apontar aqui os inúmeros trabalhos na ciência política que evidenciam os problemas teóricos e metodológicos deste tipo "mecanicista” de explicação. Apenas para ficar num clássico exemplo, cf. FIGUEIREDO, Argelina Cheibub. Democracia ou Reformas Alternativas Democráticas à Crise Política 1961 a 1964. São Paulo: Paz e Terra, 1993.

${ }^{22}$ Com efeito, os representantes da ideologia nacional-desenvolvimentista estavam entre os primeiros a terem seus direitos políticos suspensos. Com a promulgação do Ato Institucional $\mathrm{n}^{0} 1$, seriam cassados, além dos políticos diretamente responsáveis pelo regime anterior, como João Goulart, Jânio Quadros,
} 
axiais do pensamento sobre a qual se assentava, em especial, a noção de uma burguesia nacional e progressista. Com efeito, o consentimento sub-reptício ou a participação direta de setores organizados das elites dirigentes nos eventos que culminaram na ruptura do sistema político brasileiro, seria um duro golpe para todos aqueles que acreditavam no caráter "revolucionário” e democrático da classe burguesa do país. O estabelecimento, com o apoio entusiasmado da "burguesia nacional", de um modelo de desenvolvimento economicamente subordinado (embora, paradoxalmente, nacionalista), politicamente fechado e socialmente excludente, liquidará a idéia de um grupo capitalista interessado nas tarefas democrático-burguesa, e deixará transparecer seu verdadeiro caráter, antipopular e heterônomo. Mais ainda: conforme esse modelo vai se consolidando, a partir de 1968 com enorme êxito, outra crença compartilhada pela maioria dos autores nacional-desenvolvimentistas seria abalada, qual seja, a de que existia uma relação direta entre desenvolvimento econômico ${ }^{23}$, democracia e justiça social - ou, parafraseando Hirschman, a presunção de que "all good things go together” ${ }^{24}$. Como os fatos cruelmente demonstrariam, o período em que o Brasil experimentou suas maiores taxas de crescimento, até hoje, foi também aquele em que se observou uma piora acentuada na distribuição de renda e uma repressão política sem precedentes na história recente do país (os chamados “anos de chumbo”).

Os fatores acima aludidos evidenciaram as limitações e as insuficiências teóricas das interpretações nacional-burguesa do ISEB, do PCB e em boa medida da própria Cepal. A ideologia que durante aproximadamente 15 anos havia entusiasmado e capturado a imaginação de boa parte da esquerda brasileira entrava assim num período de franca decadência. É evidente que seus autores não permaneceram alheios à realidade, que se transformava na direção oposta aos prognósticos anteriormente traçados. Conforme assinalamos no capítulo anterior, já na virada dos anos cinquenta

Leonel Brizola, Miguel Arraes, seus mais eminentes intelectuais, como Celso Furtado, Nelson Werneck Sodré, Guerreiro Ramos, dentre outros.

${ }^{23}$ É também mais ou menos por essa época que o próprio conceito de desenvolvimento começa a ser repensado. Se até aquele momento desenvolvimento era sinônimo de desenvolvimento econômico, que por sua vez tendia a ser identificado como crescimento econômico, a partir de então diversos pesquisadores ao redor do globo passarão a questionar essa definição estreita do termo. Para eles, a noção de desenvolvimento não devia incluir apenas a dimensão econômica (crescimento da renda per capita, do Produto Interno Bruto, etc.), como também ou principalmente a dimensão social e cultural (redução ou eliminação da desnutrição infantil, erradicação da pobreza, aumento dos níveis de escolaridade, entre outros). É por isso que a partir daí o termo desenvolvimento será cada vez mais acompanhado do vocábulo "social" ou "humano". Sobre isso, veja-se ARNDT, H.W. op.. cit., p.89-114.

${ }^{24}$ Cf. HIRSCHMAN, Albert. "The Rise and Decline of Development Economics". In: Essays in Trespassing: economics to politics and beyond. Cambridge: Cambridge University Press, 1981, p. 20. 
para os sessenta, o pensamento que melhor fundamentara teoricamente o nacionaldesenvolvimentismo, isto é, o estruturalismo da Cepal, iniciara um processo de profunda reformulação analítica e metodológica. O otimismo inicial da escola cepalina em relação à industrialização periférica será então substituído pelo ceticismo, e deste para um mal-disfarçado pessimismo. A tônica a partir daí será menos o de defender a necessidade da industrialização e do planejamento estatal, processos bem ou mal, consolidados, e aceitos até entre os adeptos do chamado livre mercado, do que o de criticar os graves desequilíbrios sociais e regionais trazidos pela modernização da estrutura produtiva e, conseqüentemente, o de sustentar reformas sociais e institucionais que recolocassem o desenvolvimento econômico brasileiro em seu devido eixo. $\mathrm{O}$ desdobramento dessa veia teórica não vai demorar em desembocar na tese “estagnacionista”, isto é, de que a economia brasileira, e latino-americana mais amplamente, tendia à estagnação, e de que sem uma reorientação no estilo de desenvolvimento, no sentido de alargar o mercado consumidor (por meio de reformas que distribuíssem rendas e terras) e evitar o desperdício de poupança potencial (leia-se, desestimular o padrão impróprio de consumo das classes mais abastadas), seria impossível manter um ritmo satisfatório de crescimento econômico, correndo-se inclusive o risco do retorno ao agrarismo ${ }^{25}$. Com isso, o foco da atenção das análises estruturalistas voltar-se-ia menos para os fatores eminentemente econômicos do processo de desenvolvimento, que para aqueles explicitamente políticos e sociais: a crônica má distribuição de renda, a concentração fundiária, o padrão “imitativo" de consumo das altas classes, a urbanização desenfreada, a perda do controle nacional dos centros de decisão etc.

Não obstante sua reformulação e sua posição mais crítica quanto às conseqüências da industrialização latino-americana, o pensamento estruturalista já não exercera mais a atração e influência de outrora, seja por sua dificuldade em diagnosticar os problemas econômicos e oferecer soluções convincentes para os mesmos (evidenciada no mal-sucedido Plano Trienal, de Celso Furtado ${ }^{26}$ ), seja porque o

25 A expressão mais contundente da tese estagnacionista encontra-se em FURTADO, Celso. Subdesenvolvimento e estagnação na América Latina. Rio de Janeiro: Civilização Brasileira, 1966. Mas diferentes "versões" dessa tese também podem ser vistas em PREBISCH, Raúl. Hacia una dinámica del desarrollo latinoamericano, op. cit.; e também em PINTO, Anibal. "Notas sobre la distribución del ingreso y la estrategia de la redistribución”. Revista Brasileira de Ciências Sociais, Belo Horizonte, mar. 1962.

${ }^{26}$ Comentando sobre as deficiências do plano, argumenta Ricardo Bielschowsky “[...] o plano é bastante precário no que diz respeito ás análises e propostas globais e setoriais de crescimento e de investimento, 
contexto sociopolítico da época demandava uma leitura muito mais crítica e desapegada em relação ao padrão de desenvolvimento vigente, o que significava ir além do reformismo cepalino e de sua fé, já um tanto abalada, em relação ao protagonismo nacional-burguês.

É nesse momento que uma nova matriz teórica vai ganhando força no pensamento brasileiro e latino-americano. Para a incipiente perspectiva analítica, não bastava analisar como os condicionantes externos (imperialismo na linguagem do ISEB e do PCB, e relação centro-periferia na terminologia estruturalista) levavam a uma estrutura arcaica e subdesenvolvida. Havia que considerar que a dinâmica desse processo era dada também (ou, sobretudo) pelas perspectivas e contradições surgidas no âmbito da estrutura de classes local. Nesses termos, tão importante quanto apontar para a exploração dos centros desenvolvidos sobre as regiões periféricas ao redor do globo, era verificar como, a partir das relações de poder no interior da própria periferia, essa dominação externa se consubstanciava e se perpetuava. Em outras palavras, a dependência econômico-social podia ser vista não apenas como um fenômeno externamente condicionado, mas também como um processo internamente mediado. Dentro do próprio pólo periférico, inúmeros fatores de natureza econômica, política, social e cultural faziam com que seus grupos e classes sociais dominantes - que no Brasil incluía um numeroso empresariado industrial - se associassem de maneira subalterna aos interesses dos países centrais, o que, conseguintemente, tornava a crença desenvolvimentista na "revolução nacional-burguesa” ou, para usar a expressão de Furtado, na “internalização dos centros de decisão”, uma idéia não apenas insustentável do ponto de vista teórico e empírico, como potencialmente nociva do ponto de vista político, já que pressupunha a liderança desse grupo no consórcio de poder e na “direção" do empreendimento estatal. Portanto, o cerne da crítica do novo modelo de análise em relação às interpretações dos pensadores desenvolvimentistas recaía sobre seu recorte metodológico (e ideológico) em omitir, suavizar, ou simplesmente equivocar-se sobre um dos aspectos centrais no estudo do desenvolvimento, isto é, os chamados “fatores internos”, o que levava esses pensadores a crer numa incoerente aliança proletário-burguesa e a depositar suas esperanças numa inconsistente idéia de

ou seja, é fraco justamente na dimensão de planejamento que era mais cara à tradição da corrente desenvolvimentista nacionalista [...] as únicas propostas que tinham chances concretas de aplicação pelas autoridades econômicas diziam respeito à tentativa de controle inflacionário - via contenção de crédito e das despesas públicas - e às medidas para contornar o estrangulamento externo, ambas visando o curto prazo”. BIELSCHOWSKY, Ricardo, op. cit., p. 415-416 
autonomia nacional. Nos marcos do capitalismo periférico, argumentarão os autores da teoria da dependência, não era possível haver um verdadeiro desenvolvimento (isto é, nacional e autóctone), apenas um desenvolvimento do subdesenvolvimento, um subcapitalismo ou um desenvolvimento dependente e associado. 


\section{A Teoria da Dependência}

Ao contrário de outras escolas de pensamento, incluindo-se aí o estruturalismo da Cepal, em que há uma certa uniformidade teórica e metodológica nos diversos trabalhos escritos por seus integrantes, assim como há na literatura especializada uma definição mais ou menos consensual sobre suas principais características e autores, não há em relação à assim chamada teoria da dependência essa mesma convergência conceitual e tipológica. Muito pelo contrário, divergem analiticamente entre si seus mais eminentes representantes - para não mencionar as mudanças de posicionamento que os próprios autores tiveram ao longo de suas carreiras - assim como diferem as interpretações e distinções feitas sobre a escola da dependência. Antes, porém, de examinar estas pronunciadas diferenças analíticas e classificatórias, convém realizar uma breve genealogia das idéias que fomentaram o surgimento da supracitada escola de pensamento latino-americana.

De maneira geral, há três principais matrizes teóricas que contribuíram para o aparecimento da escola latino-americana da dependência nos anos 1960: o marxismo, as teorias do imperialismo e o estruturalismo da Cepal. Por certo, houve influências de outras matrizes teóricas, que, obviamente, variou de autor para autor, como o weberianismo, a escola de Frankfurt, o neo-marxismo americano, etc., entretanto, nenhuma delas "estruturou” o debate como as três anteriormente mencionadas. Embora haja divergências sobre o peso que cada uma delas teve para a formação da matriz teórica da dependência ${ }^{1}$, o certo é que as três, em seu conjunto, forneceram grande parte do instrumental analítico, metodológico e conceitual que os pensadores da escola dependentista viriam a utilizar ou desenvolver em maior profundidade em seus estudos, incluindo-se aí o termo que dá nome à escola. Com efeito, em todas essas linhagens intelectuais há registros freqüentes do uso dos vocábulos “dependente”, “dependência”

\footnotetext{
${ }^{1}$ Cristóbal Kay, Joseph Love e João Manuel Cardoso de Mello, por exemplo, enfatizam muito mais as similitudes com o estruturalismo cepalino, ao passo que Gabriel Palma, Ronald Chilcote, e Heraldo Munõz dão mais destaque às ligações com o marxismo e com as teorias do imperialismo. Cf. KAY, Cristóbal, op. cit., p.10; LOVE, Joseph, op. cit., p.427-471; CARDOSO DE MELLO, João Manuel. O capitalismo tardio. 11a . ed. São Paulo: Editora Unesp, 2009, p. 24 ; PALMA, Gabriel. "Dependency: A formal theory of underdevelopment or a methodology for the analysis of concrete situations of underdevelopment". World Development, n6, 1978, p. 882; CHILCOTE, Ronald. "Issues of Theory in Dependency and Marxism”. In: CHILCOTE, Ronald (ed). Latin American Perspectives, Number 1, 1982, p. 3-16; MUÑOZ, Heraldo. "Cambio y continuidad en el debate sobre la dependencia y el imperialismo". Revista de Estudios Internacionales, 2, nº. 44, out. dez. 1978, p. 88-138.
} 
ou “país dependente”, embora não necessariamente os termos viessem acompanhados de uma definição expressa ou tivessem grande importância heurística na análise. Assim, por exemplo, Marx, no primeiro volume de O Capital, ao discorrer sobre a gênese do capitalismo industrial na Inglaterra, faz menção à expressão “países dependentes”, referindo-se a nações que, como a Irlanda, eram retardatárias (e por isso mesmo, subordinadas) no processo de desenvolvimento industrial. Entretanto, isso não significava para ele que a hegemonia do país britânico seria um empecilho para a constituição de uma moderna economia industrial nos demais, ao contrário, antes lhes serviam como parâmetro para as transformações econômicas e sociais que inexoravelmente iriam ocorrer. Marx sintetiza muito bem essa idéia no famoso aforismo "De te fabula narratur”, ou em outros termos, "o país industrialmente mais desenvolvido mostra ao menos desenvolvido tão-somente a imagem do próprio futuro" $^{2}$. Ainda que ao final de sua vida, Marx (e mais ainda Engels, que viveria doze anos a mais que seu antigo parceiro, e vislumbraria com maior nitidez a emergência de um capitalismo monopolista) começasse a se distanciar dessa visão etapista e linear de história, sobretudo ao analisar os casos russos e chinês, tudo leva a crer que, para ele, a expansão do capitalismo em âmbito global resultaria não num crescente desequilíbrio econômico e político entre as nações, mas sim numa proliferação de sociedades capitalistas autônomas, difundindo-se, com isso, o processo ocorrido na Inglaterra, e que parecia estar ocorrendo também nos Estados Unidos e em outros países europeus ${ }^{3}$.

Seria apenas na virada do século XIX para o XX, com o aparecimento de fenômenos não-previstos pelo marxismo clássico, como o imperialismo ou a lenta marcha da modernização econômica em vastas regiões do planeta, que a noção de uma estrutura hierárquica profundamente desigual no sistema econômico mundial, e portanto, de uma relação de poder e de dependência entre umas nações e outras, começa a ganhar forma. Assim, uma série de autores - em sua maioria, e não à toa, provenientes de regiões "periféricas” do mundo capitalista à sua época, como a Rússia e a Alemanha - dentre os quais, Hobson (este, um não-marxista), Hilferding, Kautsky, Bukharin, Luxemburgo, e o mais influente deles todos, Lênin, assinalavam a natureza e a dinâmica da nova etapa da expansão capitalista internacional - caracterizada àquele momento

\footnotetext{
${ }^{2}$ MARX, Karl. O Capital. Vol. 1, Livro Primeiro. São Paulo: Abril Cultural, 1983, p.12.

3 Para uma discussão sobre esse tema na obra de Marx, vide PALMA, Gabriel. "Dependencia y desarrollo: una visión crítica”. In: SEERS, Dudley (org.). La teoría de la dependencia: una evaluación crítica. México, D.F. : Fondo de Cultura Económica, 1987, p. 21-30
} 
pelo predomínio do capital monopolista e financeiro - sob a ótica principal, mas não exclusiva, dos países que comandavam esse processo, isto é, as nações industrializadas ${ }^{4}$. Desta maneira, se o marxismo clássico proveio as leis ou categorias fundamentais que permitiam explicar o funcionamento do capitalismo em seu nível mais abstrato e essencial (a mais-valia, a exploração da força de trabalho, o processo de formação e acúmulo de capital etc.), as teorias do imperialismo forneceram uma primeira visão mais elaborada de como esse sistema, especialmente a partir de sua fase monopólica, organizava-se e articulava-se numa escala planetária, provocando um desenvolvimento “desigual e combinado” em seus diferentes pólos. Com isso, introduziram no marxismo um tema até então pouco explorada por ele, qual seja, o problema do atraso econômico em países capitalistas de desenvolvimento retardatário.

Apesar dessas idéias dizerem muito a respeito do desenvolvimento econômico e social da própria América Latina, e talvez mais ainda, proverem um ferramental teóricometodológico para o estudo do capitalismo em regiões pobres e periféricas do mundo, elas não tiveram maior repercussão no debate local contemporâneo - salvo, evidentemente, na obra de alguns isolados e cosmopolitas autores, como Haya de La Torre e José Carlos Mariátegui no Peru ou Caio Prado Jr. no Brasil ${ }^{5}$-, em parte, devido ao fraco enraizamento institucional do marxismo durante as primeiras décadas do século passado na maioria dos países da região ${ }^{6}$. Dessas diversas formulações, a única que chegará com força no debate brasileiro, já nos idos dos anos 1950, será a concepção, retratada no capítulo anterior, do chamado "Modelo Democrático Burguês”, difundida no país pelo PCB, seguidor que era das diretrizes da Terceira Internacional. Em certo

\footnotetext{
${ }^{4}$ De fato, a maior parte dos autores aludidos examinava o imperialismo a partir do ponto de vista das chamadas "potências imperialistas". Mas há exceções. Lênin, em estudo famoso sobre o desenvolvimento capitalista na Rússia, de 1899, tem como objeto de análise a formação econômica de uma nação "atrasada" e claramente dependente do capitalismo inglês, como era o seu país de origem na entrada do século vinte. Daí porque há quem considere esta obra, a pioneira nos estudos sobre a dependência. Cf. PALMA, op. cit., p. 32; e também, até certo ponto, CARDOSO, Fernando Henrique. "Notas sobre o estado atual dos estudos sobre a dependência”, op. cit., p. 30-72.

${ }^{5}$ Dado os paralelismos entre as análises de Mariátegui e a dos autores da teoria da dependência, há quem o considere "[...] the most important Latin American "father" or "grandfather" of dependency writings." PACKENHAM, Robert, op. cit., p. 11. Por essa mesma razão, e talvez até mais que o autor peruano, poder-se-ia afirmar o mesmo do autor de Formação do Brasil Contemporâneo.

6 "Antes da Segunda Guerra Mundial, os latino-americanos tinham maior familiaridade com o pensamento francês, britânico e espanhol do que com o alemão, o que provavelmente tendia a limitar seu conhecimento do marxismo [...] O radicalismo, na maior parte da América Latina, como também acontecia na Península Ibérica, tendia a girar mais em torno do anarquismo que do socialismo, pelo menos até a década de 1920 e, em muitos países, o Brasil inclusive, talvez até a década de 1930. Além do mais, a maioria dos partidos socialistas não era de orientação exclusiva ou predominantemente marxista, até que a Terceira Internacional, em 1919, forçou a definição dessa questão”. LOVE, Joseph, op. cit., p. 406-407.
} 
sentido, a escola latino-americana da dependência "resgata”, complementa e atualiza muitas das importantes contribuições analíticas e metodológicas formuladas meio século antes pelos autores das teorias do imperialismo (reduzidas estas que estavam à caricata concepção da “coligação feudal-imperialista” como um obstáculo ao desenvolvimento).

Finalmente, a terceira das matrizes teóricas fundamentais para o surgimento da teoria da dependência nos anos 1960 foram os trabalhos da escola estruturalista da Cepal. Não nos cabe, nesse momento, entrar em detalhes dos inúmeros vínculos intelectuais, institucionais e pessoais dessas duas escolas mutuamente influentes do pensamento político-social latino-americano (que, de resto, será exaustivamente abordado nos próximos capítulos). Apenas a título introdutório, convém observar que um dos primeiros livros a registrar o termo “dependente” em seu título - quiçá, o primeiro de um autor latino-americano - foi a obra de Celso Furtado, denominada Uma economia dependente, de 1956, embora a análise do autor situava-se, àquele momento, numa chave eminentemente estruturalista, ou mesmo “pré-estruturalista”. Não será difícil, outrossim, encontrar esse mesmo vocábulo em diversos outros textos de autores da escola cepalina, embora, tal como na obra do economista brasileiro, fosse empregado como sinônimo, variante ou simplesmente complemento das noções de economia “colonial”, “periférica”, “exportadora”, “subdesenvolvida”, entrea outras. Sem embargo, mais importante que o termo em si mesmo, foram os diversos ensinamentos teóricos, empíricos e metodológicos trazidos pelo pensamento estruturalista, tais como, a concepção centro-periferia, a análise histórico-estrutural dos fenômenos econômicos, a deterioração dos termos de intercâmbio, o princípio normativo de se romper com as amarras da teoria econômica convencional etc. Ainda que de maneira parcial, esses ensinamentos apontaram o caminho das pedras por meio do qual os estudos econômicos e sociológicos sobre o capitalismo na América Latina poderiam ser conduzidos, a fim de se realizar uma análise integrada do desenvolvimento. Nesse sentido, mais do que uma perspectiva meramente crítica ao reformismo pequeno-burguês da Cepal, os estudos sobre a dependência pretenderam constituir-se em uma espécie de "auto-crítica” de seu legado, que, sem deixar de evidenciar suas falhas e limitações, souberam reconhecer sua importância e influência. Quanto a isso, a avaliação de um dos pensadores da escola da dependência, o sociólogo Fernando Henrique Cardoso, é sintomática: 
Convém reafirmar que sem os estudos da Cepal, e de Prebisch em particular, a "superação" da análise econômica tradicional pelo marxismo de cátedra ou dos pequenos grupos guardiães de livros sagrados seria tão formal quanto o foi a crítica abstrata da inviabilidade do capitalismo na América Latina na "atual etapa do imperialismo", tão comum e sensaborona. A preocupação analítica da Cepal e sua visão estruturalista são ganhos líquidos do pensamento social latinoamericano e a única crítica válida, também neste caso, é a autocrítica. Em certa medida, os estudos sobre a dependência constituíram uma espécie de auto-crítica dinamizada pelo ardor dos que, sem ter jamais passado pela escola cepalina, souberam, entretanto, criticá-la sine ira et studio. ${ }^{7}$

Ao que chegamos assim em meados dos anos sessenta, quando a desconstrução do antigo discurso nacionalista-desenvolvimentista e a crítica ao processo de industrialização engendrado no Brasil e em alguns países vizinhos, tornam-se então visão-comum no seio da esquerda intelectual e, ao mesmo tempo, elementos que ensejariam o surgimento de uma nova interpretação sobre a natureza, a dinâmica e as possibilidades do desenvolvimento “dependente” da América Latina. Com efeito, conforme a situação política, social e econômica da região como um todo foi se deteriorando ao longo de toda a década de 1960 - situação essa agravada pelos sucessivos golpes militares no Cone-Sul - também foram se avolumando, sem que seja possível estabelecer com isso um "marco inaugural” ${ }^{8}$, os estudos enfatizando o caráter dependente dos Estados nacionais da região (no que se ressaltava seu componente político e institucional), de suas elites dirigentes (no que se debatia seu aspecto sóciopolítico e cultural) e do próprio desenvolvimento capitalista desses países (no que se

\footnotetext{
${ }^{7}$ CARDOSO, Fernando Henrique, op. cit., p. 41.

${ }^{8}$ A questão sobre quem teria sido $O$ "fundador" da teoria da dependência é praticamente tão antiga quanto os próprios estudos sobre a dependência. Não obstante esta polêmica ter consumido muitos litros de tinta durante os anos 1970, consideramos de pouca relevância a recuperação do debate para o presente trabalho, e isto por dois motivos. Primeiro porque interessa menos saber quem teria dado inicio a tal ou qual proposição, do que em explorar as similitudes e diferenças das teses dependentistas entre elas e em relação às escolas de pensamento anteriores e contemporâneas. Segundo porque, da perspectiva do presente trabalho, o surgimento da teoria da dependência pode ser visto muito mais como sendo o resultado de um processo de amadurecimento das ciências sociais latino-americanas, do que da obra de alguns iluminados profetas. Sem dúvida, como tentaremos demonstrar nas próximas seções, algumas obras contribuíram decisivamente para a difusão e popularização da escola da dependência. Entretanto, mesmo estas não podem ser concebidas fora do contexto social, político e cultural em que se inseriram (notadamente, o ambiente da capital chilena na segunda metade dos anos sessenta). Neste sentido, concordamos com Fernando Henrique Cardoso, que, após comentar sobre os possíveis precursores da teoria da dependência, ressalta que "[...] provavelmente uma série de outros autores, ao mesmo tempo e independentemente [...] contribuíram para a análise das formas atuais da dependência. Se se buscar com atenção provavelmente se encontrará quem antes e independentemente de todos tenha escrito sobre o mesmo tema. Vê-se, pois, que mesmo do ângulo mais limitado da história intelectual vista pelas "obras e autores”, o pensamento é um produto social. Quando uma idéia expressa, de fato (teórica ou ideologicamente) um aspecto do real, ela surge ou ressurge por toda a parte”. Idem, Ibidem, p. 40. Para uma discussão "arqueológica" sobre quem teria sido "o precursor" da escola dependentista, vide PACKENHAM, Robert, op. cit., p.19-24.
} 
demonstravam suas origens econômicas e extra-continentais), assim como foram se multiplicando as diversas expressões e acepções possíveis associadas ao vocábulo em questão (sociedade dependente, dependência interno-externa, dependência cultural e assim por diante).

Claro estava a mudança de paradigma em relação às interpretações “otimistas” e um tanto quanto voluntariosas do desenvolvimento nacional-burguês, no entanto, isso não era condição suficiente para atribuir à noção de dependência - que, muitas vezes, à maneira de um deus ex machina, passava a ser utilizada para explicar o trama de todo e qualquer fenômeno social periférico - um sentido unívoco e preciso, quanto mais para imputar-lhe um estatuto teórico próprio, conforme reivindicavam alguns de seus entusiastas e “criadores”. Um dos primeiros a perceber a ambivalência e imprecisão com que o termo vinha sendo utilizado, o cientista político Francisco Weffort ${ }^{9}$, a esse respeito indagava:

[...] quanto mais se amplia o uso desta noção [dependência], tanto mais se faz necessária uma indagação sobre seu significado. De que se trata, precisamente? É razoável supor que se pretende mais que oferecer um novo rótulo para a velha idéia de "país semi-colonial". Contudo, se se pretende propor um novo conceito, qual seu estatuto teórico? Se se trata de uma nova teoria sobre o desenvolvimento latino-americano, como se articula com a teoria geral do sistema capitalista? Ou se trata apenas, hipótese que me parece mais provável, de apresentar não uma teoria, mas uma problemática? ${ }^{10}$

De forma análoga, João Quartim de Moraes perguntava-se o que devia ser entendido com a idéia de dependência: uma teoria, um conceito, uma noção, uma perspectiva, uma “caracterização concreta” etc. ${ }^{11}$ ? Diante desses e de outros tantos questionamentos, seus principais representantes não tardaram em explicar - em inúmeras oportunidades - o significado do termo, bem como as implicações práticas e

\footnotetext{
${ }^{9}$ Curiosamente, Weffort fora um dos entusiastas iniciais do "enfoque” sobre a dependência. Não apenas organizara conjuntamente com Fernando Henrique Cardoso um dos primeiros livros sobre o assunto (no qual, escreveriam o capítulo introdutório), como em sua tese de doutorado sobre o fenômeno do populismo no Brasil, defendida em 1968, ratificava sua filiação à referida escola de pensamento. Cf. WEFFORT, Francisco Correa. Classes populares e política: contribuição ao estudo de populismo. 148p. Tese (doutorado em Ciência Política) - Faculdade de Filosofia, Letras e Ciências Humanas, Universidade de São Paulo, São Paulo, 1968; CARDOSO, Fernando Henrique; WEFFORT, Francisco Correa. (Eds.). América Latina: ensayos de interpretación sociológico-política. Santiago de Chile: Universitaria, 1970.

${ }^{10}$ WEFFORT, Francisco. "Notas sobre a "teoria da dependência": teoria de classe ou ideologia nacional?”. Estudos Cebrap, São Paulo, vol. 1, 1971, p.3.

${ }^{11}$ MORAES, João Quartim de. "Le statut théorique de la rélation de dépendence”, IV Seminaire LatinoAméricain, CETIM, Genève, abril de 1972. Também reproduzido em ANDA et. al. (eds.) Dependencia y estructura de clase en America Latina. Genebra:Centre Europe-Tiers Monde, 1972.
} 
metodológicas para o estudo do desenvolvimento na América Latina. Assim, por exemplo, Fernando Henrique Cardoso, respondendo à Weffort, e numa espécie de mea culpa sobre a imprecisão teórica do "brumoso" conceito de dependência, tentava esclarecer:

Nos trabalhos que escrevi sobre dependência existe uma dupla intenção crítica. Por um lado [...] critica-se as análises do desenvolvimento que abstraem os condicionamentos sociais e políticos do processo econômico e critica-se as concepções evolucionistas (das etapas) e funcionalistas (especialmente a teoria da modernização) do desenvolvimento. A crítica se faz mostrando-se que o desenvolvimento que ocorre é capitalista e que não pode desligar-se do processo de expansão do sistema capitalista internacional e das condições políticas em que este opera. Por outro lado, a crítica se orienta para mostrar [...] que a análise "estrutural” dos processos de formação do sistema capitalista só tem sentido quando referida historicamente. Que quer dizer isto?

Quer dizer, basicamente, que as estruturas condicionantes são o resultado da relação de forças entre classes sociais que se enfrentam de forma específica em função de modos determinado de produção. Trata-se, portanto, de valorizar um estilo de análise que apanha os processos sociais num nível concreto. $^{12}$

Em caracterização não muito distinta, Theotônio dos Santos põe nos seguintes termos a definição sobre o conceito e o campo de estudos do fenômeno da dependência:

O conceito de dependência permitia mostrar os laços entre nossas sociedades e as economias nacionais e regionais e a economia mundial sob a forma de imperialismo. Seria impossível conceber as relações socioeconômicas que se desenvolviam no interior de nossas sociedades sem iluminá-las com a expansão do capitalismo mundial do centro para a periferia. Mas seria também impossível compreender corretamente as economias centrais sem vinculá-las à sua expansão colonial e imperialista.

[...] A complexidade de temática nos obrigou a romper com os enfoques estáticos e a-históricos, com maior ou menor profundidade. Chegou-se a criar um consenso sobre a necessidade de uma metodologia histórico-estrutural que se opusesse à dicotomia entre o devenir histórico e sua apreensão como sistema. Com maior ou menor êxito, desenvolveu-se na região uma prática científica voltada para a análise concreta dos processos sociais como continuidade histórica e como estruturas dialeticamente interatuantes ${ }^{13}$.

Vê-se, pois, que, não obstante o uso generalizado, e muitas vezes impreciso, que a noção de dependência teve nas ciências sociais latino-americanas a partir dos anos

${ }^{12}$ CARDOSO, Fernando Henrique. "Teoria da dependência” ou análises concretas de situações de dependência?”. Estudos Cebrap, São Paulo, vol. 1, 1971, p.27-28, grifos do autor.

${ }^{13}$ SANTOS, Theotônio dos, op. cit., p. 129 
1960, havia entre seus principais expoentes alguns alicerces teóricos e metodológicos comuns, que podem ser assim resumidos:

a) a caracterização da dependência, ou do subdesenvolvimento, como um fenômeno histórico-estrutural singular (isto é, não meramente uma “etapa” ou um “estágio” do desenvolvimento”, nem tampouco um evento histórico isolado, uma “anomalia” do sistema econômico ) e, simultaneamente, indissociável da organização e dinâmica do capitalismo em âmbito internacional;

b) porém, não redutível a esta esfera analítica, isto é, a dependência é concebida por meio de uma relação “dialética” entre os fatores internos e específicos (a estrutura de classes local, o sistema político nacional, as orientações valorativas dos atores etc. $)^{14}$ e os condicionantes gerais e externos (o grande capital, a divisão internacional do trabalho, o "imperialismo" etc.), o que equivale afirmar que, mais do que do que uma simples decorrência de fatores exógenos globais, a dependência era vista como sendo mediada ou expressa internamente, por meio de uma série de interesses, articulações ou objetivos dos grupos sociais locais;

c) e, finalmente, apreendida ao nível do concreto ou das situações concretas de dependência, daí porque, pelo menos idealmente, as análises tivessem por objetivo (ou ponto de partida) o exame da luta de classes em seu contexto nacional, e não uma vaga e abstrata "análise de classes" 15.

Apesar da relativa concordância quanto a esses princípios teóricometodológicos (menos talvez, em relação ao terceiro ponto), e, conseguintemente, quanto à pertinência de um campo de estudos "próprio" ou de uma teoria sobre a dependência contemporânea, as análises e perspectivas sobre o desenvolvimento

\footnotetext{
${ }^{14}$ Para uma das vertentes da teoria, o capitalismo dependente possuía também suas próprias "leis" internas de desenvolvimento. A esse respeito, vide o capítulo seguinte sobre a versão ortodoxa da dependência.

${ }^{15}$ Sobre isso, e ainda respondendo a Weffort, que defendia uma "perspectiva de classe" sobre a perspectiva supostamente ambígua (entre o approach de classe e o approach nacional) da teoria da dependência, argumenta Cardoso: "Em termos teórico-metodológicos seria uma volta atrás [...] insistir apenas nas contradições gerais entre relações de produção e relações de classe, como pretende Weffort, sem mostrar que elas se articulam, ainda hoje, através do Estado e da Nação. Não se iria além de petições de princípios e de uma dialética ao nível da oposição abstrata entre conceitos, se deixássemos de caracterizar precisamente a "ambigüidade" da situação, sempre e quando se entenda, como o fizemos, que neste caso essa ambigüidade nada mais é do que a forma como a contradição aparece, ao nível de percepção dos agentes. Uma análise dialética que não marcasse as ambigüidades e que passasse sem mediações das relações de produção às relações de classe não seria uma análise concreta de movimentos sociais estrutural-historicamente condicionados, que foi o que pretendemos fazer”. CARDOSO, Fernando Henrique, op. cit., p. 36.
} 
capitalista periférico tiveram desdobramentos bastante distintos, dando origem a diferentes correntes ou enfoques dentro da escola de pensamento em questão. E também em relação a este tópico não há um consenso, isto é, há praticamente tantas classificações, distinções e denominações sobre as vertentes da teoria da dependência quanto são seus interpretes. Sem ter a pretensão de ser exaustivo na recuperação dessas inúmeras interpretações - esforço ademais muito superior às limitadas possibilidades deste trabalho - convém passar brevemente em revista algumas delas.

Em uma das primeiras sistematizações sobre o debate, Gabriel Palma ${ }^{16}$ distingue três abordagens (não-mutuamente excludentes) sobre as análises da dependência. A primeira delas, que ele denomina de “dependency as 'theory of Latin American underdevelopment', seria a vertente preocupada em determinar as leis do desenvolvimento dependente, e teria em André Gunder Frank, Ruy Mauro Marini, Theotônio dos Santos, e Caputo e Pizarro seus mais eminentes representantes; a segunda, por ele chamada de "dependency as a reformulation of the ECLA [CEPAL] analysis of Latin American development” seria a corrente formada por Prebish, Furtado e demais egressos da escola estruturalista, quando, ao incorporarem os aspectos sociais e políticos do processo de desenvolvimento, passam a reformular o pensamento originário da Cepal; e, finalmente, a terceira vertente, que seria não tanto uma “teoria”, mas uma "methodology for the analysis of the concrete situations of dependency", compreenderiam todos aqueles estudos que empreendessem uma análise "concreta" das situações de dependência, à maneira de Fernando Henrique Cardoso e Enzo Faletto em sua seminal obra Dependência e Desenvolvimento na América Latina.

Já para Cristóbal Kay, haveria basicamente duas vertentes principais nos estudos sobre a dependência, isto é, a vertente reformista e a vertente marxista. Na primeira, estariam autores como Cardoso, Faletto, Sunkel, Furtado, Jaguaribe, Ferrer e Anibal Pinto, cujas idéias "are best seen as a further development of the ECLA structuralist school as they attempt to reformulate ECLA's developmentalist position in the light of

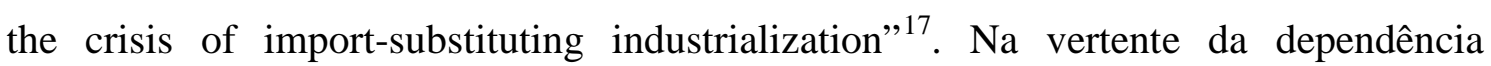
marxista, estariam nomes como Mauro Marini, Theotônio dos Santos, Gunder Frank, Oscar Brun, Vânia Bambirra, Aníbal Quijano, e outros, que, utilizando um instrumental marxista, viam na revolução socialista a única maneira de sobrepujar o

\footnotetext{
${ }^{16}$ PALMA, Gabriel, op. cit., 881-924

${ }^{17}$ KAY, Cristóbal, op. cit., p. 127
} 
subdesenvolvimento e a dependência. Kay faz menção ainda a uma "escola caribenha da dependência”, mas ele mesmo adverte que se tratava antes de autores compartilhando uma mesma referência temática (o desenvolvimento nos países caribenhos), do que possuindo afinidades teóricas, conceituais ou ideológicas comuns. Classificação semelhante faz Joseph Love, embora o autor prefira denominar de "não-marxista” a versão da teoria da dependência ligada a Cardoso e seus colaboradores ${ }^{18}$.

Para Guido Mantega, a teoria da dependência também poderia ser divida em duas correntes, aquela ligada a Cardoso e Faletto por um lado, e a associada a Furtado e Sunkel por outro. De forma distinta das demais interpretações, todavia, o autor deixa de fora todos aqueles autores mais diretamente associados à versão radical da teoria, como Frank, Marini e dos Santos, aos quais prefere denominá-los de neomarxistas. Isto porque, em sua avaliação, dependentistas seriam tão-somente “[...] aqueles pensadores que fizeram um esforço de superação das teses cepalinas, estagnacionistas e neomarxistas, e conseguiram desenvolver uma nova abordagem do capitalismo retardatário brasileiro, baseada na estrutura de dominação, na luta de classes, enfim, nos seus condicionantes internos" ${ }^{19}$. Desta forma, todos aqueles que assinalavam a inviabilidade do capitalismo periférico, ou que caracterizavam a dependência a partir de um ângulo exclusiva ou principalmente externo, não poderiam ser enquadrados nos marcos da teoria da dependência.

Um dos participantes do debate sobre a dependência, o economista Luiz Carlos Bresser-Pereira, num trabalho que analisa as principais interpretações sobre 0 desenvolvimento da formação social brasileira em 50 anos, dos anos 1930 aos anos 1980, distingue seis principais teorias ou interpretações, duas das quais correspondendo às análises da dependência, quais sejam, “a interpretação da superexploração imperialista”, corrente integrada por Frank, dos Santos, Marini, e até em certa medida, Florestan Fernandes, e a “interpretação da nova dependência”, formada pelos autores de Dependência e Desenvolvimento, além de Celso Furtado, Carlos Lessa, Maria da Conceição Tavares, José Serra, Antônio Barros de Castro, Paul Singer, ele próprio, e inúmeros outros intelectuais e pesquisadores que buscavam "[...]compreender a realidade brasileira a partir dos fatos novos que modificaram profundamente durante os

\footnotetext{
${ }^{18}$ LOVE, Joseph, op. cit., p. 427-471

${ }^{19}$ MANTEGA, Guido, op. cit., p. 28
} 
anos cinqüenta”20. Em trabalhos mais recentes, entretanto, assumindo ter uma visão mais clara sobre a perspectiva analítica (e política) que fundamentava os trabalhos de Fernando Henrique Cardoso ${ }^{21}$, o autor propõe uma nova classificação. Bresser-Pereira distingue então três versões da teoria: a da superexploração, que permanece a mesma de seu trabalho anterior; a da dependência-associada, que seria a corrente liderada por Cardoso, e cuja tese central seria a impossibilidade da existência de uma "burguesia nacional” na periferia, daí porque o desenvolvimento latino-americano só seria possível de uma forma subordinada ou associada; e, por fim, a versão que ele denomina de "nacional-dependente”, que reuniria a maioria dos antigos autores nacionaldesenvolvimentistas, como Furtado e ele próprio, e cuja premissa fundamental seria a de que “[...]o desenvolvimento [nacional periférico] é possível porque existe sempre a possibilidade de os empresários e os intelectuais voltarem a se associar aos trabalhadores e aos técnicos do governo em torno de questões e de uma estratégia nacional”22.

Há também trabalhos que classifiquem a obra de Cardoso e Faletto numa chave marxista-ortodoxa, e os trabalhos de Frank numa vertente não-marxista da dependência ${ }^{23}$. Outras interpretações consideram não apenas os textos de Gunder Frank, mas todos os trabalhos da escola dependentista numa chave não-marxista ${ }^{24}$. E há ainda quem distinga os estudos sobre a dependência em uma grande variedade de tipos, tais como “Heretical Dependency”, “Analytic Dependency”, “Bargaining Dependency”, "World-Systems", entre outros, e incluiriam autores tão diferentes entre si quanto Hélio Jaguaribe e Immanuel Wallerstein ${ }^{25}$.

Como se vê, há inúmeras possibilidades de se classificar os autores e vertentes da escola dependentista. É provável que existam ainda tantas outras tipologias quantos sejam os interpretes do debate. Sem embargo, a pequena amostra aqui reunida já nos dá uma idéia de como essas classificações podem variam, por vezes diametralmente, entre si. Conquanto todas elas tenham sua razão de ser, parece-nos que várias delas padecem

\footnotetext{
${ }^{20}$ BRESSER-PEREIRA, Luiz Carlos, “Seis interpretações sobre o Brasil”, op. cit., p. 293

21 "Durante muito tempo, eu não vi com clareza a distinção entre essa versão [a de Fernando Henrique Cardoso] e a minha própria da teoria da dependência, que denomino “nacional-dependente”. BRESSERPEREIRA, Luiz Carlos. "Do Iseb e da Cepal à Teoria da Dependência”, op. cit., p. 222

${ }^{22}$ Idem, ibidem, p. 224.

${ }^{23}$ BLOSTRÖM, Magnus; HETTNE, Bjorn. La teoria del desarollo en transicion. Mexico D.F: Fondo de Cultura Económica, 1990.

${ }^{24}$ LARRAIN, Jorge. Theories of Development. London: Polity Press, 1989

${ }^{25}$ PACKENHAM, Robert, op. cit., p. 111
} 
de uma tentativa de se criar uma artificiosa polaridade entre análises de "raiz marxista" e análises de "raiz estruturalista", como se fossem atributos mutuamente excludentes, e como se não houvesse pontos de contato, numerosos até, entre essas duas linhagens do pensamento. Conforme tentaremos demonstrar nos próximos capítulos, há possivelmente tanto conteúdo estruturalista nas análises da chamada vertente "marxista" ou "neo-marxista” da dependência, quanto há fundamentos marxistas nos trabalhos da versão "reformista” ou "não-marxista” da dependência. Além do que, a denominação “marxista”, “não-marxista”, “reformista” etc., freqüentemente parece estar associada a um afã em se ressaltar as virtudes ou, inversamente, em se demonstrar os "vícios de origem” de tal ou qual enfoque analítico. Desse modo, não consideramos que a melhor maneira de se classificar as vertentes da dependência seja utilizando termos conceituais tão estreitos e, ao mesmo tempo tão complexos, como “marxista”, “não-marxista”, “weberiana”, entre outros. Tais rótulos, ainda que expliquem parte do enredo, mostramse, amiúde, insuficientes.

Também não nos parece adequado incluir entre os autores da dependência, aqueles pensadores advindos da escola estruturalista cepalina, como Prebisch, Furtado, Pinto e Sunkel. Apesar de estes reconhecerem a importância da teoria da dependência ${ }^{26}$, chegando inclusive a incorporar um "enfoque dependentista” em suas próprias análises, vale dizer, terem passado a examinar mais detidamente os condicionantes internos (o Estado, as classes sociais, o "sistema de decisões", o "sistema de cultura") do subdesenvolvimento, eles não deixaram de conceber - exceto, talvez, em alguns trabalhos marcadamente "pessimistas" entre o final dos anos sessenta e o início dos setenta - a possibilidade de se gerar na periferia um desenvolvimento capitalista autóctone, desde que fossem realizadas "profundas modificações institucionais” que mudassem o "estilo perverso" de desenvolvimento dessas regiões, dentre as quais: uma maior participação popular no processo decisório (o que, evidentemente, só poderia ser alcançado num Estado Democrático de Direito), a redistribuição das terras e rendas, a racionalização do perfil da demanda e da produção, o apoio à pequena e média burguesia vis-a-vis o grande capital nacional e estrangeiro, a defesa do "interesse

\footnotetext{
${ }^{26}$ Celso Furtado, por exemplo, afirma: “A visão que os sociólogos tiveram com o Fernando Henrique foi mais de olhar dentro da própria sociedade, como é que ela se solda e como se forma a dependência. $\mathrm{O}$ fenômeno da dependência todos conheciam, a própria teoria do semicolonialismo era uma teoria da dependência, que os marxistas desenvolviam. Ligar isso à estrutura interna da sociedade foi uma contribuição dos sociólogos”. Entrevista de Celso Furtado em BIDERMAN, Ciro et al. (Org.) Conversas com economistas brasileiros. São Paulo: Editora 34, 1996, p. 74
} 
nacional” etc. Propostas estas que, na ótica dos autores dependentistas, eram vistas como inconsistentes, inviáveis de serem alcançadas dentro dos marcos do capitalismo periférico, ou ainda pior, levariam ao aumento das iniqüidades sociais e ao aprofundamento da dependência externa. Em outras palavras, a teoria da dependência, mesmo em sua versão supostamente "reformista”, não chegou a elaborar ou mesmo contemplar uma proposta alternativa de desenvolvimento capitalista, uma que conjugasse modernização econômica, justiça social e autonomia nacional, coisa que os autores baseados na escola cepalina jamais deixaram de fazê-lo. Nesse sentido, suas idéias permaneceram essencialmente vinculadas aos fundamentos iniciais que deram origem àquela escola. Concordamos, assim, com a interpretação de Ricardo Bielschowsky, para quem o enfoque estruturalista cepalino: “[...] es el mismo independientemente del número de etapas en que pueda subdividirse. Lo que se va modificando es la historia real objeto del análisis, así como el contexto ideológico en que ésta se genera, lo que obliga permanentemente a matizar los énfasis y renovar las interpretaciones, a fin de adaptarse a los nuevos contextos históricos”27

Posto isto, a tipologia que nos parece a mais adequada (o que não quer dizer, evidentemente, que, tal como as outras, também não seja arbitrária e simplificadora), e que, em grande medida, coincide com a maneira com que os principais pensadores da teoria da dependência enxergavam o debate ${ }^{28}$, foi aquela elaborada por Jorge Dominguez $^{29}$, que distingue a teoria da dependência em duas vertentes principais: aquela ligada a André Gunder Frank, que ele classifica de “ortodoxa”, e a ligada a Fernando Henrique Cardoso, por ele denominada de "heterodoxa”. Na primeira vertente, a história tende a ser vista como “fechada”, o fenômeno da dependência é explicado por meio de "leis" internas de (sub)desenvolvimento, o capitalismo dependente é concebido como um sistema econômico-social de permanente geração de pobreza, marginalidade e estagnação, o socialismo é visto como a única alternativa para a solução dos problemas dos países periféricos etc. Na segunda, a história é vista como parcialmente aberta, a dependência é concebida e analisada em suas situações específicas e particulares, o capitalismo é visto como sendo capaz de proporcionar

\footnotetext{
${ }^{27}$ BIELSCHOWSKY, Ricardo. “Cincuenta años del pensamiento de la Cepal: una reseña”, op. cit., p. 11

${ }^{28}$ Veja-se, por exemplo, CARDOSO, Fernando Henrique. "O consumo da teoria da dependência nos Estados Unidos”. In: As idéias e seu lugar: ensaios sobre as teorias do desenvolvimento. Petrópolis: Vozes, 1993, p. 143; e também SANTOS, Theotônio, op. cit., p. 119-137

29 DOMINGUEZ, Jorge. "Consensus and Divergence: The State of Literature on Inter-American Relations in the 1970s”. Latin American Research Review, 13:1, 1978, p. 87-126
} 
algum desenvolvimento na periferia, embora seja um desenvolvimento muito sui genereis, isto é, do tipo “dependente e associado” etc. Conforme tentaremos demonstrar mais à frente, talvez as diferenças entre as vertente "ortodoxa” e "heterodoxa” da teoria da dependência não sejam assim tão pronunciadas quanto Dominguez, e boa parte da literatura especializada, sugerem. Entretanto, para efeitos de simplificação e exposição, adotatemos esta terminologia daqui em diante. Passemos, então, ao exame mais atento destas duas correntes da escola dependentista. 


\subsection{A Versão Ortodoxa da Dependência}

$\mathrm{Na}$ entrada dos anos sessenta do século anterior, com a crise do nacionaldesenvolvimentismo e com o radicalismo político que o acompanhou, vai ganhando musculatura no âmbito da esquerda brasileira uma nova visão sobre a dinâmica e sobre os rumos do desenvolvimento capitalista engendrado no país. Insatisfeitos com as opções ideológicas e com as limitações analíticas das interpretações nacional-burguesa do ISEB, do marxismo "oficial" - isto é, o do PCB, que insistia em transpor mecanicamente para a América Latina o mesmo esquema teórico utilizado na interpretação da evolução do capitalismo europeu -, e até, em boa medida, da própria Cepal, seus adeptos irão propor novas leituras sobre o capitalismo periférico, bem como novas estratégias políticas para sua superação. A fim de construir um modelo de análise que tivesse o duplo objetivo de proporcionar uma melhor caracterização do processo histórico dos países latino-americanos e o de ensejar a ação política revolucionária, seus teóricos beberão de diversas fontes: do marxismo (embora um marxismo distinto da linha seguida pelo "partidão, isto é, baseado sobretudo nas idéias de Trotsky, e no contexto regional, na historiografia marxista de Sergio Bagú e de Caio Prado Jr.,) ao estruturalismo cepalino; das teorias do imperialismo (especialmente da corrente luxemburguista) ao neo-marxismo americano (representado pelos economistas norteamericanos Paul Sweezy e Paul Baran); entre outros.

Embora não se possa afirmar que todas essas matrizes teóricas tenham tido o mesmo peso ou importância na montagem do modelo analítico da versão ortodoxa ou radical da dependência, o certo é que cada uma delas elas influiu, em maior ou menor grau, para a formação daquele quadro. Nesse sentido, seus autores irão se apoiar em caracterizações, tais como: a noção do desenvolvimento desigual e combinado, bem como a idéia de uma revolução permanente, ambas tomadas de Trotsky; a concepção de que a economia brasileira e latino-americana havia sido desde seu passado colonial essencialmente capitalista, não possuindo, portanto, qualquer resquício feudal, como supunha o PCB, ou mesmo traços pré-capitalistas, conforme sustentava Celso Furtado (concepção essa advinda ou derivada de Sergio Bagú, de Caio Prado Jr. ${ }^{30}$ e de outros

\footnotetext{
${ }^{30}$ Embora Caio Prado Jr. jamais tenha afirmado categoricamente que o Brasil ou a América Latina houvessem sido capitalistas desde seu período colonial mais remoto, não chega a ser inteiramente fora de propósito fazer essa leitura de sua obra (como, aliás, fariam alguns de seus mais eminentes discípulos).
} 
intelectuais latino-americanos ${ }^{31}$ ), assim como a caracterização da história econômica da região como intrinsecamente relacionada à da economia mundial (idéia igualmente derivada dos supra-citados cientistas sociais, assim como da escola cepalina); a noção de excedente potencial, concebida por Sweezy e por Baran; e em diversas formulações dos autores estruturalistas, como a idéia de um sistema centro-periferia, a concepção furtadiana sobre a “involução econômica”, boa parte da periodização histórica, etc.

É do amálgama e lapidação desse caldeirão de idéias, não necessariamente compatíveis entre si, que vai emergir a tese central da versão ortodoxa da dependência, qual seja, a de que não era possível haver um pleno desenvolvimento nos marcos do capitalismo periférico, apenas um desenvolvimento do subdesenvolvimento, uma vez que o atraso e a pobreza dessas regiões constituíam a contrapartida histórica e necessária ao avanço econômico e social dos países ricos. É que as grandes potências econômicas mundiais, exercendo seu poder imperialista sobre os países satélites que orbitam ao seu redor, subtraem dessas regiões boa parte do excedente que elas geram, fazendo com que o processo de acumulação capitalista aí realizado seja insuficiente para gerar um desenvolvimento econômico auto-sustentado. Por seu turno, a permanente drenagem de capitais promovida pelos centros hegemônicos levava o país explorado a compensar a perda econômica por meio de processos sociais e políticos, tais como o da super-exploração do trabalho ou o sub-imperialismo. Além disso, argumentarão seus expoentes, não se encontra por parte das elites periféricas resistência à essa situação de subordinação externa, ao contrário: eram estes mesmos grupos ou camadas sociais que cultivavam e davam vazão à dependência político-econômica que historicamente a América Latina, e a periferia como um todo, havia sido submetida. Assim, não se

Sua celebre formulação sobre o sentido de colonização, isto é, fornecer produtos tropicais e minerais para um mercado capitalista internacional em expansão, embora fosse profícua e altamente estimulante, era também, em boa medida, ambivalente. Sobre isso, comenta Bernardo Ricupero: “[...] Caio é dos autores que melhor demonstra que o mais importante na Colônia eram as relações econômicas exteriores à sociedade brasileira. Ou melhor, o que realmente contava eram as relações da Colônia com a Metrópole no quadro da economia mundial capitalista em constituição. Mas se o que define um modo de produção são as relações de produção dominantes numa formação econômico-social concreta, como tratar de uma sociedade em que o mais importante são relações de circulação (no caso, externas a essas sociedades)? Ou, colocando o mesmo problema em termos opostos: se se considerar que fomos sempre capitalistas, já que estivemos, desde a nossa colonização, integrados ao nascente sistema capitalista internacional, como tratar das relações de produção escravistas prevalecentes no interior da formação econômico-social colonial? Caio Prado Jr. não chega a resolver o problema; evita, porém, equívocos, como o de considerar o Brasil como capitalista desde sempre ou caracterizar o que existia aqui como um modo de produção específico, mas principalmente chama a atenção para a questão fundamental do período colonial: o peso que têm fatores externos à sociedade então em formação.” RICUPERO, Bernardo. Caio Prado Jr. e a nacionalização do marxismo no Brasil. São Paulo: Editora 34, 2000, p. 154.

${ }^{31}$ Para uma antologia desses autores, veja-se LÖWY, Michael (org.). Le Marxisme em Amérique Latine de 1909 à nos Jours: Anthologie. Paris: F. Maspero, 1980. 
poderia esperar das burguesias dessas regiões um papel de liderança rumo a uma autêntica revolução nacional, democrática e burguesa. Seus verdadeiros objetivos estariam na associação com o capital internacional, na aliança com forças sociais reacionárias e no apoio à repressão e ao autoritarismo políticos (com o que garantiria sua acumulação dependente). Nesse quadro, a única possibilidade de redenção social aos povos oprimidos da América Latina seria por meio de uma revolução socialista imediata, que poria fim à subjugação imperialista e tornaria possível realizar as tarefas “democrático-burguesas”, que as burguesias periféricas não tinham o interesse e nem a capacidade histórica de realizar. Em última análise, a revolução socialista nos países subdesenvolvidos abriria caminho para o socialismo em escala planetária, uma vez que os países capitalistas centrais dependiam economicamente do excedente que era permanentemente subtraído ou expropriado da periferia.

Essas idéias formam, em linhas gerais, o arcabouço teórico central em torno do qual se constituiu o que denominamos aqui de versão ortodoxa da dependência. É evidente que seus autores não chegaram a formulá-las, da maneira pronta e acabada como foram acima expostas, logo em seu prólogo. Pelo contrário, este quadro foi se desenvolvendo e ganhando seus devidos contornos na medida em que os acontecimentos políticos e as transformações socioeconômicas na América Latina foram “confirmando” ou dando razão aos argumentos desses diversos autores. Nesse sentido, é com a derrubada de várias das frágeis democracias do continente iberoamericano, com o aporte maciço de empresas multinacionais em associação com as burguesias locais, e com o aumento mais ou menos generalizado dos níveis de pobreza na região, que a versão ortodoxa da teoria da dependência foi se formatando e arrebatando novos adeptos. Além do mais, dentro desse arcabouço teórico mais ou menos amplo, havia importantes diferenças analíticas entre alguns de seus principais intérpretes. Portanto, para entender melhor como este quadro foi se constituído, e também as diferentes caracterizações e perspectivas que havia em seu interior, convêm retratar sucintamente o contexto político, econômico e social em que essas idéias surgiram, bem como a trajetória intelectual dos principais nomes que ajudaram a formar esta vertente da teoria da dependência.

Embora exista uma quantidade relativamente razoável de pensadores que tenham contribuído para a formação e evolução desta linhagem do pensamento social latinoamericano, três são seus autores mais freqüentemente citados e cujas idéias pautaram 
grande parte do debate sobre a dependência, especialmente fora do Brasil. Trata-se dos economistas André Gunder Frank, Theotônio dos Santos e do cientista-social Ruy Mauro Marini ${ }^{32}$. Um dos fatores que ajudam a centralidade, e, até certo ponto, a complementaridade do pensamento desses três autores, é a similar trajetória que eles tiveram entre os anos sessenta e setenta do século passado, período em que se registram suas maiores contribuições aos estudos da dependência.

Único dos principais representantes da escola dependendista a vir de fora da América Latina, o alemão André Gunder Frank, nascido da Alemanha mas radicado ainda na infância nos Estados Unidos, teve uma formação acadêmica bastante peculiar (considerando-se os rumos posteriormente tomados pelo autor). Curiosamente, Frank cursara o doutorado em economia na Universidade de Chicago, baluarte institucional do liberalismo naquele período, e tivera como um de seus professores ninguém menos que Milton Friedman, possivelmente o economista liberal mais influente do século XX, e um dos responsáveis intelectuais pela avalanche neoliberal que varreria o pensamento econômico a partir dos anos 1970. Após o término de seu doutorado, em 1958, Frank ficaria por algum tempo ainda nos EUA, ministrando aulas na Michigan State University e pesquisando temas relacionados à mudança social (nesse momento, mais preocupado com a dimensão antropológica do fenômeno do que com a dimensão propriamente econômica ou historiográfica, como mais tarde viria a desenvolver). Buscando pesquisar o tema da mudança social e do desenvolvimento no interior de seu locus preferencial, isto é, os países subdesenvolvidos, Frank partiria para uma longa andança pela América Latina. Depois de passar por Cuba, México, Peru, Bolívia e Chile, se instalaria no Brasil, ainda nos primeiros anos da década de 1960. Em seus primeiros trabalhos em terras brasileiras, Frank escreveria alguns artigos em que questionava a eficácia das reformas sociais e criticava o papel dos investimentos estrangeiros, particularmente os norte-americanos, para o desenvolvimento do país ${ }^{33}$. A grande repercussão que suas idéias geraram no já inflamado debate político brasileiro da época, render-lhe-ia um convite do reitor da recém criada Universidade de Brasília -

\footnotetext{
${ }^{32}$ Além destes, ajudariam a constituir a versão ortodoxa da dependência nomes como: Vânia Bambirra, Marta Harnecker, Augustin Cueva, Pio Garcia, Orlando Caputo, Roberto Pizarro, entre outros.

${ }^{33} \mathrm{Um}$ desses artigos seria publicado pelo Jornal do Brasil, na época um dos jornais de maiores circulações no país, daí a notoriedade que o economista germano-americano logo adquiriu nos cenário político e acadêmico brasileiros. Este artigo encontra-se reproduzido em FRANK, Andre Gunder. "Aid or exploitation". In: Latin America: Underdevelopment or Revolution. Essays on the development of underdevelopment and the immediate enemy. New York: Modern Reader, 1969, p. 149-174 (a versão do jornal foi publicada em 17 de março de 1963).
} 
UNB, Darcy Ribeiro, para integrar o corpo de professores daquela instituição, em 1962. Nela, Frank daria aula para dois dos outros nomes principais que viriam a desenvolver, junto com ele, a versão ortodoxa da teoria da dependência, isto é, os brasileiros Ruy Mauro Marini e Theotônio dos Santos.

Esses, por sua vez, além das atividades propriamente acadêmicas realizadas enquanto estudantes de pós-graduação, exerciam também uma intensa militância no movimento estudantil e em agremiações políticas, tendo inclusive ajudado a fundar, em 1961, a auto-denominada Organização Revolucionária Marxista - Política Operária (POLOP), um dos vários agrupamentos políticos marxistas que surgiriam nos anos sessenta em decorrência da insatisfação com as estratégias e orientações políticas do “partidão”. É desse encontro da esquerda brasileira radical, com a renovada perspectiva do neo-marxismo americano, que Frank trazia dos EUA, que vai se forjando uma nova interpretação histórica, não apenas sobre o capitalismo periférico, como também da própria organização e evolução do sistema capitalista em escala planetária. Neste primeiro momento, menos do que a formulação rigorosa de conceitos ou fundamentos teóricos, as análises da emergente perspectiva dependentista prestavam-se mais a negar algumas das formulações correntes no seio da esquerda política brasileira (como as concepções reformistas de autores como Celso Furtado $^{34}$, ou a interpretação esquemática dos “resquícios feudais” do $\mathrm{PCB}^{35}$ ) e a propor a necessidade da revolução socialista imediata. Foi também imbuído desse espírito, isto é, de crítica aos rumos do capitalismo engendrado no país e também às propostas de cunho reformistas, que se formaria entre os estudantes da UNB um seminário para a leitura e discussão d'O Capital, nos moldes do seminário formado alguns anos antes por alguns professores e alunos da USP com este mesmo propósito ${ }^{36}$.

Com o golpe militar de 1964, e a perseguição do novo regime às personalidades consideradas politicamente “subversivas”, o grupo é obrigado a se exilar do país, mas

\footnotetext{
${ }^{34}$ Cf. FRANK, Andre Gunder. "A Pré-Revolução de Celso Furtado. A Contra-revolução de Celso Furtado”. O Semanário, Rio de Janeiro, No. 342, Julho, 1963, p. 18-24.

${ }^{35}$ Veja-se, em especial, o artigo no qual Frank, seguindo os passos que já vinham sido dados por Caio Prado Jr. desde o final dos anos 1940, rejeita totalmente a tese defendida pelo PCB de que haveria resquícios feudais no setor agrícola brasileiro. Para ele, este setor, como todos os demais, possuíam uma natureza econômica e social inteiramente capitalista; seu atraso e pobreza relativos deviam ser atribuídos à própria estrutura monopolística e exploratória do modo capitalista de produção. $C f$. FRANK, Andre Gunder. "A Agricultura Brasileira: Capitalismo e o Mito do Feudalismo”. Revista Brasiliense, Sao Paulo, $\mathrm{n}^{\circ}$. 51, 1964, p. 45-70. Sobre a visão de Caio Prado Jr. sobre esse tópico vide sua coleção de artigos reunidos em A Questão Agrária. São Paulo: Editora Brasiliense, 1979.

${ }^{36}$ Vide mais detalhes na próxima seção.
} 
suas trajetórias pessoais permaneceriam ainda interligadas. Theotônio partiria em 1966 para o Chile, país no qual se encontraria mais tarde com Frank e Marini, que haviam inicialmente se refugiado no México, abrigando-se profissionalmente na Universidade Nacional Autônoma do México - UNAM, sob os auspícios do sociólogo mexicano Pablo González Casanova. Nos anos seguintes, com a deterioração da situação política e social do continente como um todo, vão se popularizando e ao mesmo tempo se multiplicando os estudos sobre o tema da dependência. Contribuirá para essa isso a publicação e ampla difusão do livro de Andre Gunder Frank, Capitalism and Underdevelopment in Latin America (1967), no qual o autor sistematiza e ao mesmo tempo aprofunda algumas de suas teses anteriores. Pelas idéias, influência, repercussão, e também pelas polêmicas que suscitou em todo o continente, o livro pode ser considerado como um dos marcos inaugurais da teoria da dependência ${ }^{37}$. No ano seguinte, em 1968, com o fatídico episódio conhecido como Massacre de Tlatelolco, desencadeado a partir de manifestações dos estudantes da própria UNAM contra o governo federal daquele país, a situação política no México também se agravaria bastante, obrigando muitos intelectuais estrangeiros a deixar o país, incluindo-se aí, os pensadores vinculados à teoria da dependência. Tendo tido as portas "fechadas" no México, no Brasil, e, no caso de Frank, nos Estados Unidos, todos eles migrariam para o único provável país da região no qual suas idéias e propostas eram bem vistas, isto é, o Chile, à época governado por Eduardo Frei, e logo a seguir por Salvador Allende.

No Chile, além do respaldo do governo central, os três contariam também com um excepcional suporte institucional. Naqueles anos, a capital chilena contava com inúmeras e respeitadas instituições de ensino e pesquisa, tais como a Cepal, a Faculdade Latino-americana de Ciências Sociais - Flacso, a Faculdade de Economia da Universidade do Chile, a Escola de Sociologia, o Instituto Latinoamericano de Planejamento Econômico e Social - ILPES, instituição vinculada à Cepal, e por fim o Centro de Estudos Sócio-Econômicos - CESO, instituição na qual seriam admitidos como pesquisadores e em pouco tempo ganhariam proeminência (Theotônio dos Santos, por exemplo, tornar-se-ia diretor da instituição). Com suas diversas instituições científicas e acadêmicas, e com um governo central que, havia alguns anos, promovia e

\footnotetext{
37 O fato da obra ter sido inicialmente publicada em inglês também contribuiu para a sua grande repercussão em todo o mundo. Para efeitos de comparação, a outra grande obra da teoria da dependência, Dependência e Desenvolvimento na América Latina, de Cardoso e Faletto, ganharia sua primeira versão em inglês apenas em 1979, mais de 10 anos após sua primeira edição, e quanto o tema já se encontrava em franca decadência nas ciências sociais.
} 
dava suporte às pesquisas sobre o desenvolvimento econômico da região ${ }^{38}$, Santiago convertera-se numa espécie de meca do pensamento político-social latino-americano, na qual diversos pensadores exilados ou refugiados de seus países de origem encontrariam abrigo. Além dos nomes diretamente associados à versão ortodoxa da dependência, por lá passariam também figuras como Celso Furtado, Fernando Henrique Cardoso, José Serra, Francisco Weffort, Betinho, Darcy Ribeiro, Ferreira Gular, Régis Debray, Sérgio Bagú e inúmeros outros intelectuais brasileiros, argentinos, uruguaios, bolivianos, peruanos, mexicanos, europeus e norte-americanos, que, com suas diversas experiências sócio-culturais e seus distintos posicionamentos ideológicos (em sua maioria, entretanto, situados no campo da esquerda), enriqueceriam extraordinariamente o ambiente intelectual da capital chilena. É desse fértil período de pesquisas, discussões e reflexões em torno do tema do desenvolvimento e do subdesenvolvimento da América Latina, que seriam escritas e publicadas algumas das obras mais importantes da teoria da dependência, tais como Latin America: Underdevelopment or Revolution (1969), de Andre Gunder Frank, Dependência e Desenvolvimento na América Latina (1969), de Fernando Henrique Cardoso e Enzo Faletto, Dialética da Dependência (1973), de Ruy Mauro Marini, entre outros. A partir dessas e inúmeras outras obras, o prestígio da escola dependentista aumentaria substancialmente, atingindo um nível de reconhecimento na comunidade acadêmica internacional até então inédito para uma escola de pensamento surgida na América Latina, superior inclusive ao atingido alguns anos antes pelo estruturalismo da Cepal. Também é nesse período que as disputas de ordem teóricas e políticas em torno do conceito de dependência se agudizariam, dando origem, por fim, a correntes teóricas distintas.

Com o golpe militar em 1973, a grande maioria desses autores, e naturalmente, os três a que vimos aludindo, seria obrigada a escapar do Chile a fim de preservar a própria vida. Theotônio dos Santos e Ruy Mauro Marini (este, após breve passagem pela Alemanha) migrariam para o México, alocando-se novamente na UNAM; Andre Gunder Frank iniciaria um périplo ao redor do mundo, a começar pelo continente

\footnotetext{
${ }^{38}$ A própria criação da Cepal fora resultado de uma iniciativa daquele país junto às Nações Unidas, em 1947. Após sua aprovação no conselho da ONU, no ano seguinte, a Comissão Econômica para a América Latina seria criada e instaurada na capital chilena. Cf. LOVE, Joseph, op. cit., p. 308. A partir daí, e até o golpe militar em 1973, as relações entre o governo chileno e a instituição seriam intensas. Dois de seus pesquisadores ocupariam cargos centrais em duas diferentes administrações. O economista chileno Jorge Ahumada seria alçado ao posto de conselheiro econômico-chefe do governo Eduardo Frei (1964-1970). E o também economista chileno, Pedro Vuskovic, tornar-se-ia Ministro da Economia no governo de Salvador Allende (1970-1973).
} 
europeu. A partir de então, embora o tema da dependência permanecesse na ordem do dia e gozasse ainda de elevada popularidade no meio acadêmico, a produção teórica desses autores se voltaria para análises cada vez mais "generalistas" e abstratas sobre o capitalismo $^{39}$, ou então, para textos de combate à versão co-irmã da dependência ${ }^{40}$. No caso de Frank, essa ruptura ocorreria ainda mais cedo e de forma bastante abrupta. Já em 1972, o autor sentenciaria a "morte da teoria da dependência”, passando a dedicar a maior parte de seu tempo e de seus esforços criativos no estudo da acumulação capitalista em âmbito histórico e global ${ }^{41}$. Seus trabalhos nessa direção somar-se-iam aos de Immanuel Wallerstein, Samir Amin e Giovanni Arrighi na construção da chamada teoria do sistema-mundo. Dos anos 1980 em diante, por motivos que discutiremos mais à frente ${ }^{42}$, o tema da dependência, pelo menos tal qual caracterizada na década anterior, praticamente desaparecia da agenda de pesquisa desses autores, como, aliás, das ciências sociais latino-americanas de maneira geral.

Feita essa breve exposição do contexto geral e da trajetória dos principais autores da versão ortodoxa da dependência, é possível notar que esta vertente da teoria constituiu-se e teve seus trabalhos mais relevantes escritos num curto, porém bastante profícuo período (entre 1967 e 1973, aproximadamente), intervalo no qual seus autores trabalharam de forma eminentemente colaborativa e conviveram grande parte do tempo juntos. Daí também porque suas análises e perspectivas, em que pesem as importantes diferenças, em diversos aspectos convergiam ou simplesmente se complementavam.

\footnotetext{
${ }^{39}$ Veja-se, por exemplo: SANTOS, Theotônio dos. Concepto de clases sociales. Buenos Aires: Editorial Galerna: 1974; e, do mesmo autor, Imperialismo e Empresas Multinacionais. São Paulo: Paz e Terra, 1977.

${ }^{40}$ Cf. MARINI, Ruy Mauro. "Las razones del neo-desarrollismo, respuesta a F.H. Cardoso y J. Serra”. Revista Mexicana de Sociología, México, Facultad de Ciencias Políticas y Sociales, UNAM, 1978, p. 57106.

${ }^{41}$ Em suas notas autobiográficas, Andre Gunder Frank revela em detalhes como se deu essa passagem: "In 1972, at the UNCTAD III meetings in Santiago, I heard 'development of underdevelopment' sloganized by establishment Third World delegates from afar. So I decided it was time to move on. In the same 'UNCTAD' building a few months later, I gave a paper at the Latin American Congress of Sociology. It was entitled 'Dependence is Dead, Long Live Dependence and the Class Struggle'. The message was that dependence itself was alive and kicking, but that the usefulness of dependence theory for political action had come and gone. [...] A few months later still in 1972, I went to Rome via Dakar. I stopped off in Dakar for a conference at which Samir Amin wanted to introduce dependence theory to Africans. Then in Rome in 1972, I announced that the world had entered a new Kondratieff B period of crisis. Giovanni Arrighi had put me on that track. I said that the socialist countries were starting to reintegrate in the capitalist world economy. I also repeated that not dependence theory but the analysis of the world crisis of capital accumulation was then on the analytical and theoretical agenda. I would spend the next 20 years full time on this agenda, writing several crisis books, and countless articles”. FRANK, Andre Gunder. "The Underdevelopment of Development”. In: CHEW, Sing; DENEMARK, Roberto (Orgs.). The Underdevelopment Of Development: Essays In Honour Of Andre Gunder Frank. Thousand Oaks: Sage Publications, 1996, p. 32, grifo nosso.

${ }^{42}$ Vide em Considerações Finais.
} 
Conforme afirmamos anteriormente, alguns dos elementos que integram a matriz teórica comum em torno do qual se constituiu a versão ortodoxa da dependência, já se encontram presentes nos pioneiros trabalhos de Andre Gunder Frank, quando de suas andanças pela América Latina. Em particular, destaca-se um pequeno, porém muito influente texto, em que Frank apresenta algumas das teses em que ele e os demais pensadores desta corrente iriam desenvolver nos próximos anos. Trata-se do artigo de 1966, reproduzido em diversos periódicos e livros, denominado “The Development of Underdevelopment”.

Em certo sentido, Frank reproduz neste ensaio a concepção histórico-estrutural de Furtado de que "os países atualmente desenvolvidos nunca foram subdesenvolvidos, embora possam ter sido não-desenvolvidos" ${ }^{43}$, porém diferentemente do economista brasileiro, Frank rejeitava a idéia de uma sociedade periférica do tipo “dual”, em que parte da economia, devido as intensas relações com o mundo “exterior”, apresentaria uma estrutura e uma dinâmica tipicamente capitalista, e a outra parte, devido a escassez ou ausência dessas mesmas relações, possuiriam feições tipicamente pré-capitalistas ou mesmos feudais. Vale a pena aqui reproduzir sua explicação na íntegra:

Evidentes desigualdades de renda e diferenças de cultura levaram muitos observadores a ver, nos países subdesenvolvidos, sociedades e economias "duais". Supõe-se que as sociedades subdesenvolvidas estariam dividias em duas partes, e se supõe que cada uma dessas partes teria sua própria história, sua própria estrutura e uma dinâmica atual largamente independente. Supõe-se ainda que apenas uma parte da economia e da sociedade teria sido afetada de modo importante por relações econômicas íntimas com o mundo capitalista "exterior", e essa parte, afirma-se, tornou-se moderna, capitalista e relativamente desenvolvida justamente por causa desse contato. A outra parte é vista como isolada, baseada numa economia de subsistência, feudal ou précapitalista de várias formas; e por isso mesmo é que seria mais subdesenvolvida. De minha parte, acredito que a tese inteira de "sociedade dual” é falsa e que as diretrizes políticas a que conduz, se postas em prática, serviriam apenas para intensificar e perpetuar as condições mesmas do subdesenvolvimento que elas supostamente se destinam a remediar.

Um corpo crescente de evidência sugere, e tenho certeza que a futura pesquisa histórica confirmará, que a expansão do sistema capitalista nos séculos passados penetrou efetiva e inteiramente mesmo nos setores aparentemente mais isolados do mundo subdesenvolvido. Desse modo, as instituições econômicas, políticas, sociais e culturais, e as relações que atualmente observamos nas regiões mais atrasadas ou feudais de um país subdesenvolvido, são produtos do desenvolvimento histórico do sistema capitalista tanto quanto

43 FRANK, Andre Gunder. "Desenvolvimento do Subdesenvolvimento Latino-Americano". In: PEREIRA, Luiz (Org.). Urbanização e Subdesenvolvimento, $3^{\mathrm{a}}$.ed., Rio de Janeiro: Zahar, 1976, p. 26, grifos do autor. 
os traços aparentemente mais modernos ou capitalistas de suas metrópoles nacionais.

Em suma, quer as relações entre desenvolvimento e subdesenvolvimento no plano internacional, quer as instituições subdesenvolvidas das áreas domésticas chamadas atrasadas ou feudais de um país subdesenvolvido, quer as instituições chamadas capitalistas de suas áreas supostamente mais progressistas, todos esses aspectos são produtos de um processo histórico único: o processo de desenvolvimento do capitalismo. ${ }^{44}$

Para Frank, portanto, "modernidade” e "atraso", riqueza e pobreza, enfim, desenvolvimento e subdesenvolvimento, eram fenômenos coetâneos e correlatos, sendo o arcaísmo de alguns países ou regiões absolutamente funcional e necessário ao avanço econômico de outros. É que, segundo o autor, haveria uma cadeia de constelações articulando desde os setores mais avançados dos países centrais até os rincões mais pobres e remotos da periferia, num mesmo sistema global de mercadorias, serviços e capitais. Desse modo, ainda que predominassem nessas regiões relações políticas e sociais consideradas arcaicas, no plano propriamente econômico, essas áreas poderiam ser consideradas tão capitalistas quanto a mais moderna região ou setor produtivo das nações desenvolvidas. Nesse sistema, o capital ou excedente econômico seria reiteradamente drenado dos países satélites para suas respectivas metrópoles, e dessas para outras metrópoles ou para a metrópole-mundial (Inglaterra num primeiro momento, e depois os EUA), do qual todos seriam satélites ${ }^{45}$. Daí porque as tentativas de se alterar a situação periférica mediante reformas ou incentivos que melhorassem sua pobre estrutura produtiva ou elevassem a condição de vida de seus trabalhadores teriam pouca ou nenhuma chance de êxito: uma vez que o excedente econômico necessário para efetuar tais mudanças já teria um destino previamente determinado, as grandes

\footnotetext{
${ }^{44}$ Idem, Ibidem, p. 27, grifo nosso.

${ }^{45}$ É possível notar uma clara semelhança entre o sistema metrópole-satélite de Frank, com a concepção centro-periférica de Prebisch, da qual provavelmente se inspirou. Entretanto, há uma diferença fundamental em relação aos escritos do economista argentino. Se para Prebisch a diferenciação econômica e social entre os diferentes pólos do sistema se dava em função da intensidade com que o progresso técnico difundia-se pelo interior dos respectivos aparelhos produtivos, assim como da capacidade de cada sociedade de preservar para si os frutos desses ganhos; para o economista germanoamericano, a raiz da desigualdade estava na relação imperialista estabelecida entre metrópoles e satélites, que, drenando o capital dos últimos em direção aos primeiros, promovia o desenvolvimento destes e o subdesenvolvimento daqueles. Nesse sentido, "Frank, obviamente, discordava de Marx e de Prebisch, os quais, afirmando que o aumento da produtividade era a essência do desenvolvimento capitalista, não acreditavam que o desenvolvimento do Centro teria que se dar basicamente à custa da Periferia”. LOVE, Joseph, op. cit., p. 450-451.
} 
metrópoles mundiais, não haveria possibilidades objetivas de se criar nos países satélites as condições para um desenvolvimento capitalista do tipo clássico.

A partir deste macro-mecanismo histórico do "desenvolvimento do subdesenvolvimento”, Frank concebe cinco hipóteses sobre a dinâmica do sistema capitalismo na periferia; as quais, sendo devidamente “confirmadas” em seus próximos estudos empíricos, ganhariam o status teórico de "leis” do desenvolvimento capitalista dependente $^{46}$. A primeira dessas hipóteses, da qual deriva todas as demais, afirma que, nas condições normais de existência do sistema econômico mundial, o verdadeiro desenvolvimento só pode ocorrer nas metrópoles; nos países satélites, isto é, naqueles historicamente especializados nas atividades primário-exportadoras, apenas um desenvolvimento muito limitado e disforme pode deflagrar-se. Como conseqüência, e esta é a segunda hipótese, nas regiões periféricas do globo o processo de desenvolvimento somente pode ocorrer, se e quando houver um isolamento econômico dessas regiões, isto é, quando os vínculos existentes entre metrópoles e satélites, em virtude de guerras, crises econômicas ou qualquer outra circunstância histórica, encontrarem-se debilitados ou rompidos. É por isso que, de acordo com o autor, locais que em séculos anteriores sofreram algum tipo de isolamento, como Mendoza, Rosário, Assunção, São Paulo, ou o exemplo mais bem sucedido, o Japão, puderam experimentar, durante o tempo em que permaneceram isolados, um desenvolvimento econômico autogerado. Entretanto, prossegue ele, ao se recobrarem as condições normais de funcionamento do sistema econômico internacional, o desenvolvimento autônomo aí experimentado seria abortado ou tornar-se ia insustentável. Isso explicaria o grande impulso na industrialização latino-americana, especialmente na Argentina e no Brasil, ocorrido no período entre-guerras, assim como, a tendência desse crescimento vir a ser abortado, dado a recuperação metropolitana após a Segunda Guerra Mundial: “[...]longe de se terem tornado mais desenvolvidos, os setores industriais do Brasil e mais visivelmente da Argentina estão se tornando estruturalmente cada vez mais subdesenvolvidos e cada vez menos capazes de gerar uma industrialização continuada ou de sustentar o desenvolvimento da economia. Esse processo, do qual a Índia também sofre, se reflete em toda uma gama de problemas cambiais e inflacionários e outras dificuldades econômicas, políticas, e promete não ceder a nenhuma solução que não

\footnotetext{
46 Veja-se, especialmente, seus estudos de caso sobre o Brasil e o Chile em Capitalism and Underdevelopment in Latin America. Harmondsworth: Penguin Books, 1969, p. 27-248.
} 
parta de uma transformação da estrutura” ${ }^{47}$. Assim, dado a o elevado nível de integração econômica já àquela época atingido pelo sistema mundial, o autor considerava cada vez menor a possibilidade dos países satélites desenvolverem suas próprias indústrias e, com isso, modificar a secular estrutura produtiva primário-exportadora típica dos países subdesenvolvidos $^{48}$. A terceira hipótese de Frank sustenta que as regiões ou países que apresentam as características mais marcadamente subdesenvolvidas são também aquelas que estiveram mais fortemente vinculadas às metrópoles no passado: “A participação dessas regiões no desenvolvimento do sistema capitalista mundial deu-lhes, já na sua idade áurea, a estrutura típica do subdesenvolvimento de uma economia capitalista de exportação. Quando o mercado para seu açúcar ou a riqueza de suas minas desapareceram, e a metrópole as abandonou à sua própria sorte, a estrutura econômica, social e política já existente nessas regiões impediu a geração autônoma de desenvolvimento econômico e não lhes deixou outra alternativa senão voltarem-se para si mesmas e degenerarem no ultra-subdesenvolvimento em que hoje as encontramos. ${ }^{49}$. A quarta e quinta hipóteses sustentam, respectivamente, que o latifúndio é um empreendimento comercial que surgiu historicamente como resposta ao aumento da demanda global de certos produtos agrícolas ou minerais, e que sua decadência se deu, principalmente, devido à queda dessa demanda.

Vê-se, pois, que o modelo de Frank, assim como a maioria dos modelos teóricos que se prestam a abstrair e formalizar as características essenciais de uma determinada estrutura econômica e social, como o subdesenvolvimento, possui como uma de suas principais virtudes o fato de ser ao mesmo tempo sintético e “aplicável”. Com efeito, a partir desse pequeno conjunto de "leis do desenvolvimento capitalista dependente”, Frank pôs-se a caracterizar, no mencionado Capitalism and Underdevelopment in Latin America, toda a história do desenvolvimento do subdesenvolvimento latino-americano, que para ele podia ser divida nos seguintes períodos ou etapas: monopólio comercial, até o século XVIII; monopólio industrial, do século XIX à época do "liberalismo"; monopólio dos bens de capital e bens-intermediários na primeira metade do século vinte, e; monopólio tecnológico e das corporações transnacionais a partir de então ${ }^{50}$. Mas, se por um lado o esquema preconizado por Frank possuía como grande trunfo as

\footnotetext{
${ }^{47}$ FRANK, Andre Gunder. "Desenvolvimento do Subdesenvolvimento Latino-Americano”, op. cit., p. 34 ${ }^{48}$ Cf. FRANK, Andre Gunder. "Capitalist Development of Underdevelopment in Brazil”. In: Capitalism and Underdevelopment in Latin America, op. cit., p. 242

${ }_{49}^{4}$ Idem. "Desenvolvimento do Subdesenvolvimento Latino-Americano", op. cit., p. 36

${ }^{50}$ Idem. Capitalism and Underdevelopment in Latin America, op. cit., p.173-242.
} 
vantagens e facilidades metodológicas da abstração teórica, em que um mesmo modelo pode ser aplicado a distintos cenários históricos, por outro lado, essa era também sua principal fraqueza. Nos anos que se seguiriam à publicação de Capitalism and Underdevelopment, Frank receberia um sem-número de críticas, do mais variado espectro ideológico e à diversos aspectos de sua tese do “desenvolvimento do subdesenvolvimento" 51 . Todavia, a crítica mais recorrente - e provavelmente a mais grave - refere-se ao insuficiente (pra não dizer ausente) tratamento que Frank dava para a questão das relações de classes e das relações de produção no interior das regiões satelitizadas, abstraindo as características concretas dessas sociedades e focando-se quase que exclusivamente na esfera da circulação de mercadorias (“circulacionismo”), da qual derivava virtualmente todos os demais fenômenos sociais e políticos em análise ${ }^{52}$. Em outras palavras, por utilizar um modelo abstrato e centrado na circulação comercial, Frank desconsiderou os chamados fatores internos atuando na conservação e reprodução do subdesenvolvimento, além de não deixar qualquer espaço em sua análise para as potenciais transformações estruturais "revolucionárias" que porventura pudessem ocorrer - como de fato ocorreu muitas vezes ao longo da história - das contradições e perspectivas surgidas no próprio seio das sociedades periféricas, a despeito mesmo da pressão imperialista pela manutenção do status quo. Assim, conforme argumentarão muito de seus críticos:

\footnotetext{
${ }^{51}$ Para um compêndio da longa lista de críticos às idéias de Frank, vide KAY, Cristóbal, op. cit., p.155162, e também PALMA, Gabriel, op. cit., p.899-905. Veja-se também, no próximo capítulo, as críticas da outra vertente da teoria da dependência às suas idéias. Na verdade, nem é preciso recorrer à fontes externas para perceber as limitações da interpretação do autor. Suas próprias hipóteses contradizem-se entre si. Afinal, se o que causava ou proporcionava o desenvolvimento capitalista do tipo clássico era o isolamento, então por que as regiões satelitizadas que haviam sido abandonadas à própria sorte pelas metrópoles, eram também as que possuíam mais sinais do subdesenvolvimento? Além disso, já àquela época existiam abundantes estatísticas - e as diversas publicações da Cepal sobre o tema são a prova mais cabal disso - sobre as elevadíssimas taxas de crescimento da indústria brasileira (particularmente de seu setor de transformação), justamente no período em que o imperialismo re-estabelecia os vínculos de dependência abalados pela Segunda Guerra Mundial, isto é, no período 1945-1960.

${ }^{52}$ A fim de responder aos diversos questionamentos, especialmente aqueles que o acusavam de negligenciar a dinâmica interna da periferia, Frank publicaria, no final dos anos setenta, um livro em que acolheria boa parte dessas críticas e repensaria sua teoria da dependência. Cf. FRANK, Andre Gunder. Acumulação dependente e subdesenvolvimento: repensando a teoria da dependência. São Paulo: Editora Brasiliense, 1980. Entretanto, conforme sustenta Guido Mantega, o objetivo pretendido pelo autor não chega a ser efetivamente alcançado, já que "[...] mesmo com a introdução da luta de classes, Frank desemboca em suas velhas conclusões e mantém suas propostas políticas, o que leva a questionar se efetivamente ele absorveu as críticas e transformou sua análise numa análise de classes (vale dizer, numa análise onde a luta de classes é o motor da história), ou se simplesmente ele acrescentou as classes ao seu esquema teórico anterior, onde a situação já estava definida. Pelo que seu resultado indica, a luta de classes, a iniciativa de certas classes, enfim, a dinâmica interna de cada país periférico, não foram levados na devida conta”. MANTEGA, Guido. A Economia Política Brasileira, op., cit., p. 222.
} 
Sem menosprezar a importância do colonialismo, do capitalismo comercial, do imperialismo, enfim, das determinações externas, não se pode reduzir todo o processo a elas, como se o Brasil fosse um mero prolongamento ou epifenômeno das metrópoles imperialistas. [...] As sociedades coloniais foram, sem dúvida, implantadas pelo capitalismo e permaneceram sob seu controle durante muitos anos. Porém, com o tempo, constituíram-se sistemas sociais locais (se não em todas, pelo menos em boa parte das colônias), com ênfase nos chamados fatores internos, que vão ganhando contornos próprios com a independência política e com a constituição dos Estados nacionais, sem, contudo, se eliminarem os laços de dependência (principalmente econômica) com as "metrópoles. ${ }^{53}$

Essa mesma limitação metodológica também seria prontamente percebida por seus mais eminentes colaboradores, entre eles, Ruy Mauro Marini e Theotônio dos Santos, que, apesar de reconhecerem a importância das contribuições de Frank para o estudo do fenômeno do subdesenvolvimento, não deixavam de enfatizar que: “[..] the process under consideration [Latin American development] rather than being one of satelization as Frank believes, is a case of the formation of a certain type of internal structures conditioned by international relationships of dependence” 54 . Em particular, discordavam da continuidade histórica que Frank estabelecia entre a "situação colonial” e a "situação de dependência”, a qual, defendiam esses autores, embora não deixasse de representar uma situação de extrema vulnerabilidade e subordinação econômica em relação aos centros hegemônicos internacionais, era qualitativamente distinta da dependência colonial, sobretudo no que se refere à dinâmica social interna, que possuía uma "vida própria", certamente condicionada mas não determinada pelo sistema mundial. Visando, assim, se aprofundar nessa importante faceta do desenvolvimento dos países periféricos, visivelmente negligenciada por Gunder Frank, ambos os autores realizariam estudos enfatizando suas internal structures, embora cada qual privilegiando um determinado aspecto do tema em questão: Theotônio explorando com maior ênfase a evolução histórica dos fatores (sobretudo os de natureza econômica) que conduziam à manutenção ou diferenciação dos vínculos de dependência, e Mauro Marini centrando sua investigação nos mecanismos e formas de exploração periféricas.

Dos autores aqui considerados, Theotônio dos Santos é provavelmente aquele que mais se empenhou em caracterizar as diversas “etapas” do desenvolvimento

\footnotetext{
${ }^{53}$ Idem, Ibidem, p. 224.

${ }^{54}$ SANTOS, Theotônio dos. "The crisis of development theory and the problems of dependence in Latin America”. In: BERNSTEIN, H. (org.). Underdevelopment and Development. Harmondsworth: Penguin Books, 1973, p.289-290 apud PALMA, Gabriel, op. cit., p. 901.
} 
capitalista na periferia e as respectivas estruturas internas de cada um desses períodos. Embora desde muito cedo o autor criticasse a visão de Frank, que atribuía excessivo peso aos fatores externos na determinação do devenir histórico das nações subdesenvolvidas, em seus primeiros trabalhos, sua própria definição sobre o conceito de dependência pouco diferia das formulações do economista germano-americano (com a importante diferença que Santos admitia a possibilidade teórica dos países periféricos obterem, porventura, benefícios econômicos da relação que mantinham com os centros hegemônicos ${ }^{55}$ ):

By dependence we mean a situation in which the economy of certain countries is conditioned by the development and expansion of another economy to which the former is subjected. The relation of interdependence between two or more economies, and between these and world trade, assumes the form of dependence when some countries (the dominant ones) can expand and can be self-sustaining, while other countries (the dependent ones) can do this only as a reflection of that expansion, which can have either a positive or a negative effect on their immediate development.[...] In the epoch of the revolutionary movement of the Third World, we have to develop the theory of laws of internal development in those countries that are object of such expansion and are governed by them ${ }^{56}$.

Assim, ainda que Santos colocasse como tarefa primordial a descoberta das leis internas do desenvolvimento dependente, sua própria definição sobre o conceito de dependência outorgava uma importância secundária e muito limitada a este objetivo, uma vez que bastaria apreender as leis do capital em escala global para desvendar a dinâmica econômica reflexa dos países do Terceiro Mundo. Em trabalhos posteriores, no entanto, Santos confere um grau de autonomia muito maior aos fatores endógenos das sociedades periféricas, admitindo, inclusive, a existência de ciclos econômicos próprios nessas regiões:

\footnotetext{
${ }^{55}$ Embora Theotônio dos Santos admitisse teoricamente a possibilidade do imperialismo vir a provocar conseqüências positivas para o desenvolvimento periférico, esta profícua e impopular tese não terá maiores desdobramentos ao longo de seus trabalhos. Pelo contrário, o autor enfatizará cada vez mais em suas próximas obras o caráter absolutamente exploratório e predatório do imperialismo contemporâneo. Veja-se, por exemplo, sua afirmação de que "Este não é um sistema de relações entre nações livres e autônomas, mas antes de tudo, de exploração e domínio. De um lado, exportação de capital; de outro, remessas de lucros. De um lado, credores; de outro, devedores. De um lado, domínio tecnológico; de outro, subjugação tecnológica. De um lado, salários mais altos e expansão do mercado interno; de outro, salários mais baixos e limitação deste mercado. De um lado, acumulação dos efeitos do desenvolvimento tecnológico, produção do conhecimento etc.; de outro, subjugação à tecnologia exportável e aos conhecimentos objetivados, e não produção deles. Em todos os planos - econômicos, político, social e cultural - se estabelece uma relação cujos efeitos sobre as respectivas estruturas sociais têm que ser antagônicas”. SANTOS, Theotônio dos. Imperialismo e corporações multinacionais. Rio de Janeiro: Paz e Terra, 1977, p. 18.

${ }^{56}$ Idem, "The structure of dependence”, The American Economic Review, vol. 60, n², May 1970, p. 231.
} 
The dominant social formations are the irradiating focus of the cycles and thus their analysis precedes or conditions the analysis of those dependent social formations which have to accommodate themselves to these international cycles reacting positively or negatively according to their internal characteristics. Among these characteristics are their own economic cycles which as they derive from their internal laws of accumulation do not necessarily coincide with the international conjunctures ${ }^{57}$

Para o autor, portanto, embora o "externo", as formações sociais dominantes, o capital internacional (financeiro, comercial ou industrial) etc., fossem o elemento estruturante de todo o sistema econômico mundial, precedendo, desta forma, a análise da formação social dependente, não deixava de ser relevante caracterizar suas leis e características internas, posto que eram estas que condicionavam o movimento da periferia em relação aos movimentos cíclicos internacionais. Nesse sentido, cada forma ou etapa histórica de dependência correspondia a uma situação não apenas condicionada pelas relações mantidas com o centro imperialista, como também mediada pelas estruturas internas de dependência, vale dizer, pela orientação do sistema produtivo, pelas formas de acumulação de capital, pelas estruturas política e social, entre outros.

Em sua periodização histórica, Theotônio dos Santos distingue três fases do desenvolvimento capitalista dependente, quais sejam: a dependência colonial, do século XVI ao XIX; a dependência financeiro-industrial, de fins do século de XIX à Segunda Guerra-Mundial, e por fim; a dependência tecnológica-industrial, a partir daí ${ }^{58}$. Vê-se, pois, que a periodização histórica do autor é bastante similar à realizada por Gunder Frank em Capitalism and Underdevelopment, entretanto enquanto este enfatizava uma mesma estrutura básica metrópole-satélite, ou um mesmo conjunto de leis do “desenvolvimento dependente” estendendo-se ao longo dos séculos, Santos colocava maior ênfase nas descontinuidades e nas diferenças histórico-estruturais de cada uma das formas históricas de dependência. Assim, durante a dependência colonial teria prevalecido o domínio do capital financeiro-comercial que, além de estabelecer uma relação comercial monopolística entre metrópoles e satélites, também ensejara o monopólio de terras, minas e força-de-trabalho nestes últimas. Já durante a dependência financeiro-industrial, entra em vigor o domínio do grande capital e da grande indústria,

\footnotetext{
${ }^{57}$ Idem, Imperialismo y Dependencia. Mexico: Ediciones Era, 1978, p.26 apud KAY, Cristóbal, op. cit., p. 149

${ }^{58}$ Idem, "The structure of dependence”, op. cit., p. 232. A mesma periodização seria reproduzida, e ampliada, em seu Imperialismo y Dependencia, op. cit., p. 310 et. seq., na qual também nos basearemos daqui em diante.
} 
que extrapola os limites nacionais metropolitanos e estende seu raio de ação até a periferia, cuja estrutura econômica especializa-se na produção de artigos agrícolaminerais demandados pelos centros hegemônicos e suas indústrias. Por fim, na dependência tecnológico-industrial, Santos vê a emergência de um novo agente da dominação imperialista, as corporações multinacionais, que, buscando novos mercados e novas fontes de lucro, passam a investir nas indústrias baseadas nos mercados internos de alguns desses países periféricos, como o Brasil, condicionando assim o seu o posterior desenvolvimento. Santos vê nessa fase, por ele denominada de nova dependência, uma mudança fundamental em relação à velha economia primárioexportadora. Nela, argumenta o autor:

El imperialismo deja de ser un "enclave” colonial y exportador, al tiempo que se cambia la división internacional del trabajo entre la producción de materias primas, por parte de los países subdesarrollados y la producción de manufacturas, por parte de los países desarrollados. Frente al crecimiento industrial de América Latina de los años 30 y a las medidas proteccionistas tomadas por los gobiernos de la época, el imperialismo se vuelve hacia el sector manufacturero, se integra a la economía moderna y pasa a dominar el sector capitalista industrial de esas economías. Esta es la nueva realidad que se constituye en Latinoamérica ${ }^{59}$.

Para Santos, essa nova fase do desenvolvimento capitalista dependente, que se inicia historicamente com a hegemonia norte-americana após a Segunda Guerra, é profundamente marcada pela concentração e internacionalização do capital monopolista, materializada pela corporação multinacional, que em seu processo de expansão passa a ditar, direta ou indiretamente, os rumos da industrialização periférica. Essa progressiva internacionalização do processo produtivo mundial, diz ele, tem uma forte coordenação dos Estados Nacionais do capitalismo central, o que não desfaz, em absoluto, o caráter anárquico do sistema capitalista, ou sua inevitável tendência estagnação e à desagregação (dado pela contradição entre uma produção cada vez mais internacionalizada frente a uma base de organização - financeira, política e militar essencialmente nacional) ${ }^{60}$. Os investimentos estrangeiros vão se concentrar, sobretudo,

\footnotetext{
${ }^{59}$ Idem, El nuevo carácter de la dependencia, Cuaderno CESO nº10, Santiago de Chile, 1968, p.15

60 "Ao contrário do que poderia derivar da proposição de alguns autores, a contradição entre a empresa chamada multinacional e o progresso humano não está em seu caráter internacional, mas na estreita base nacional em que tem que apoiar-se. Ao contrário do que aparenta, a empresa chamada multinacional é uma expressão da incapacidade do capitalismo em converter-se na base de um verdadeiro sistema econômico mundial [...] O resultado de um grande período de expansão e integração capitalista mundial só pode ser, portanto, prenúncio de um período significativo de desagregação e estagnação".Idem, Imperialismo e corporações multinacionais, op. cit., p. 30.
} 
no setor manufatureiro da economia dependente, que se torna, destarte, um elo imprescindível na cadeia produtiva mundial, uma vez que a mais-valia gerada e extraída desses mercados (a chamada "acumulação dependente”) passa a ser um elemento indispensável para atenuar, mas não eliminar, as contradições supra-citadas, inerentes ao próprio modo capitalista de produção.

E quais as conseqüências, segundo Theotônio dos Santos, dessa expansão imperialista para a economia e sociedade periféricas? Ao longo de diversos trabalhos, o autor explora uma série de tendências ou transformações estruturais que, em sua grande maioria, aprofundam ainda mais a dependência político-econômica e o subdesenvolvimento dessas regiões. Em primeiro lugar, provoca a conservação de formas e relações de produção arcaicas, como o latifúndio-minifundio, que é o que possibilita, em última instância, a obtenção dos elevados lucros das empresas multinacionais nessas regiões. Neste sentido, enseja uma aliança de classes entre a aristocracia agrária, setores burocrático-militares, a antiga "burguesia nacional” e o grande capital, que detém a posição hegemônica dentro do bloco de poder. Em segundo lugar, cria uma estrutura industrial e tecnológica divorciada das necessidades locais de desenvolvimento e cujo poder de decisão e investimento escapa quase que completamente ao controle interno do país hospedeiro. Sob esse aspecto, previne também, por contrariar os interesses econômicos dos países imperialistas, o advento de um setor de bens-de-capital, que seria, na concepção do autor, a chave para um desenvolvimento auto-sustentado ou para o término da relação de dependência ${ }^{61}$. Em terceiro lugar, aprofunda as desigualdades do sistema econômico, ensejando a concentração produtiva e de renda, sub-utilizando a capacidade instalada, monopolizando o mercado, explorando de forma intensiva os mercados concentrados nas grandes cidades etc ${ }^{62}$. Em quarto lugar, dado o insatisfatório número de empregos criados pelo setor manufatureiro, por um lado, e a baixa remuneração paga aos trabalhadores, por outro, leva a um estreitamento do mercado interno, o que conduz invariavelmente à descapitalização e à estagnação econômica ${ }^{63}$. Em quinto, exerce uma enorme influência sobre a opinião pública, mediante a criação ou financiamento de grupos de pressão (principalmente patronais), o apoio a centros de propaganda

\footnotetext{
${ }^{61}$ Idem, Imperialismo y Dependencia, op. cit., p.100

${ }^{62}$ Idem, "The structure of dependence”, op. cit., p. 234-235

${ }^{63}$ Idem, El nuevo carácter de la dependencia, op. cit., p.50
} 
ideológica, a publicidade em grandes meios de comunicação, entre outros ${ }^{64}$. E por fim, leva ao esgotamento do modelo político populista ${ }^{65}$, condicionando a instauração do regime militar, uma vez que um Estado forte e repressor torna-se uma condição necessária para garantir a ordem e implantar as medidas antipopulares (como permitir elevadas remessas divisas para o exterior ou coibir manifestações sindicais) garantidoras das altas taxas de lucro demandas pelas empresas estrangeiras.

Tendo em vista esse quadro absolutamente desolador para o desenvolvimento periférico, ou melhor, para o grosso da população desses países, e levando-se também em consideração que suas classes dirigentes não teriam interesse ou capacidade política de sustentar uma luta anti-imperialista ${ }^{66}$, Santos enxerga apenas duas alternativas históricas para o futuro da América Latina - o lema que o autor repetirá muitas vezes ao longo dos anos 1970 e que está, inclusive, no título de um de seus livros ${ }^{67}$ socialismo ou fascismo:

Everything now indicates that what can be expected is a long process of sharp political and military confrontations and of profound social radicalization wich will lead these countries to a dilemma: governments of force which open the way to fascism, or popular revolutionary governments, which open the way to socialism. Intermediate solutions have proved to be, in such a contradictory reality, empty and utopian. ${ }^{68}$

A partir da caracterização histórica de Santos e de Frank, poder-se-ia indagar como era possível o capitalismo produzir as condições necessárias para sua própria existência nos países dependentes. Afinal, se praticamente todo o excedente aí gerado era transferido às metrópoles mundiais, não restando a esses países senão a pobreza, a estagnação e o atraso, de onde brotaria então o capital necessário para a manutenção e reprodução do modo capitalista de produção, e mais ainda, para proporcionar uma constante expansão das forças produtivas (um dos preceitos normativos básicos para qualquer explicação derivada da filosofia da história marxista)? A resposta dos autores é

\footnotetext{
${ }^{64}$ Idem, Ibidem, p. 51-89

65 "Las condiciones sociales que generaran el populismo están en franca descomposición[...] En estas condiciones, no cabe ya interés alguno en un movimiento popular progresista que lucha por el industrialismo (ya victorioso), por el nacionalismo anti-imperialista (ya superado por la integración económico-social institucional con el imperialismo) y anti-oligárquico (dado que la oligarquía ruralexportadora se ajustó a las reglas del juego del gran capital y lucha para sobrevivir en cuanto le es posible). Idem, Ibidem, p.77.

${ }^{66}$ Idem, Ibidem, p.50.

${ }^{67}$ Idem. Socialismo o Fascismo: El Dilema Latinoamericano y el nuevo carácter de la dependencia. Santiago, Chile: Ed. PLA, 1972

${ }^{68}$ Idem, "The structure of dependence", op. cit., p. 236
} 
que o acúmulo capitalista nessas regiões se dava a partir de fenômenos típicos de sociedades dependentes, como a superexploração do trabalhador e o rebaixamento dos níveis salariais da população (fatores que, ambiguamente, levariam fatalmente à ruína do sistema econômico). Entretanto, os autores não desenvolvem essas idéias em maior profundidade, ou então remetem a explicação aos trabalhos de Ruy Mauro Marini, a quem ficou incumbido, assim, a tarefa de examinar em detalhes os mecanismos sóciopolíticos responsáveis pela acumulação capitalista na periferia.

Tendo participado ativamente do seminário de Marx realizado em Brasília, Marini foi certamente o membro do grupo que mais se empenhou em aproveitar suas leituras e discussões em seus textos. Com efeito, para Marini, interpretar o capitalismo dependente exigia um duplo esforço analítico: conhecer profundamente e utilizar de maneira criativa, isto é, não-dogmática, os fundamentos e as categorias marxistas de análise, e; à luz dessa "lente” materialista-histórica, examinar as particularidades e as leis específicas, embora subordinadas às leis mais gerais do capital, do desenvolvimento dependente na periferia. Tendo em vista esses princípios teórico-metodológicos, Marini formulou algumas das mais originais, e ao mesmo mais controversas, concepções da vertente ortodoxa da dependência, quais sejam, a tese da super-exploração do trabalho e, correlata e esta, a tese do sub-imperialismo; idéias expostas em duas de suas mais importantes obras, Subdesarollo y Revolución, (1969) e Dialética da dependência (1973).

De forma semelhante à André Gunder Frank e Theotônio dos Santos, Marini parte da tese do "desenvolvimento do subdesenvolvimento" - formulação por ele considerada “impecável” -, em que compete aos países economicamente subordinados na divisão internacional do trabalho fornecer o excedente de capital necessário ao progresso dos países industriais ou hegemônicos. Entretanto, o autor dá um passo além e argumenta que:

Além de facilitar o crescimento quantitativo destes [países industriais], a participação da América Latina no mercado mundial contribuirá para que o eixo da acumulação na economia industrial se desloque da produção de maisvalia absoluta à da mais-valia relativa, isto é, que a acumulação passe a depender mais do aumento da capacidade produtiva do trabalho do que simplesmente da exploração do trabalhador. No entanto, o desenvolvimento da produção latino-americana, que permite à região coadjuvar esta mudança qualitativa nos países centrais, dar-se-á fundamentalmente com base numa maior exploração do trabalhador. É este caráter contraditório da dependência 
latino-americana que determina as relações de produção no conjunto do sistema capitalista, que deve reter nossa atenção ${ }^{69}$.

O pequeno trecho acima reproduzido evidencia uma das tônicas do trabalho de Marini, que era a de tentar combinar a caracterização de Frank sobre a dinâmica capitalista global, com alguns dos conceitos-chave do marxismo clássico, como a noção de mais-valia relativa, por ele entendida como uma forma de exploração baseada fundamentalmente na transformação das condições técnicas de produção, e a mais valiaabsoluta, que Marini interpreta como sendo a mais-valia obtida através do prolongamento da jornada de trabalho ou da redução do salário pago ao trabalhador a um nível inferior ao considerado necessário à sua reprodução (ou nível de subsistência). Sua argumentação vai se constituir em torno da idéia de que a acumulação capitalista nos centros desenvolvidos se dava, principalmente, por meio da obtenção de mais-valia relativa, enquanto que nos países periféricos, baseava-se quase que exclusivamente na extração de mais-valia absoluta.

De acordo com o autor, a inserção econômica da América Latina no mercado mundial, que se realiza de maneira integral no século XIX, jogou um papel fundamental para o desenvolvimento do modo de produção especificamente capitalista, isto é, baseado na obtenção de mais-valia relativa, nos países centrais. Isto se deu, segundo ele, porque a crescente oferta de alimentos (bens-salário) colocados nos mercados pelos países latino-americanos, depreciando seu preço global, permitiu reduzir o valor da força-de-trabalho nos países que estavam se industrializando, de modo que os ganhos de produtividade aí obtidos resultassem em massas cada vez maiores de mais-valia, eludindo, desta forma, a tendência ou lei histórica observada por Marx de queda das taxas de lucro do capitalismo. Com o processo de formação e acúmulo de capital radicando cada vez mais nos ganhos advindos do progresso técnico (mais-valia relativa) e não tanto na superexploração do trabalho, houve enormes ganhos de produtividade, o que permitiu aos capitalistas dos países centrais promoverem aumentos salariais aos trabalhadores - e desta forma, constituir um robusto mercado consumidor - sem que necessitassem reduzir seus lucros ${ }^{70}$.

\footnotetext{
${ }^{69}$ MARINI, RUY Mauro. Dialética da dependência. Petrópolis: Editora Vozes, 2000, p. 112-113

${ }^{70}$ É interessante observar que não há em Dialética da dependência, uma explicação de como o aumento da taxa de mais-valia relativa nos países centrais conduziu a uma melhora das condições de vida de seus
} 
Na América Latina, por outro lado, esse mesmo processo não era possível por causa do intercâmbio desigual existente no comércio internacional, isto é, pelo fato dos países produtores de bens-primários cederem gratuitamente parte do valor que produziam aos países industriais $^{71} 72$. Marini afirma que inicialmente essa desigualdade econômica e comercial esteve baseada no uso da violência política e militar por parte dos países centrais, entretanto, sustenta ele, à medida que o mercado mundial desenvolveu-se o uso da força tornou-se desnecessário; em seu lugar, o poder monopolístico do centro, fundamentado em seu amplo domínio financeiro e tecnológico, passou a ser a principal fonte do intercâmbio desigual entre os países. A fim de compensar essa contínua sangria em seus lucros, os grupos capitalistas das nações subdesenvolvidas lançariam mão de uma exploração ainda maior dos trabalhadores, seja por meio da ampliação da jornada de trabalho, seja através da redução de seus salários, até mesmo a níveis inferiores aos da subsistência. Assim é que “[...] ]as nações desfavorecidas pelo intercâmbio desigual não buscam tanto corrigir o desequilíbrio entre os preços e o valor de suas mercadorias exportadas (o que implicaria num esforço redobrado para aumentar a capacidade produtiva do trabalho), mas compensar a perda de renda gerada pelo comércio internacional através do recurso a uma maior exploração do trabalhador”73. Mas essa superexploração, prossegue Marini, somente era possível porque os países periféricos não necessitavam de um mercado consumidor interno para realizar a acumulação capitalista: quase todos os seus ganhos advinham das exportações de produtos primários feitas às nações industrializadas. Desta

habitantes, como se essa maior taxa - fruto do intercâmbio desigual e do barateamento dos preços dos alimentos no mercado internacional - fosse uma condição ao mesmo tempo necessária e suficiente para o progresso social aí observado. É apenas em seu estudo seu estudo anterior (e, em tese, menos elaborado) que Marini constata o que Marx, em primeiro lugar, e Prebisch no contexto regional, já haviam a muito tempo demonstrado: que a organização e mobilização dos trabalhadores, em busca de maiores salários e melhores condições de trabalho, fora tão importante para o “desenvolvimento social” quanto a gigantesca oferta de alimentos provinda da periferia subdesenvolvida (se é que esta teve algum impacto significativo). Cf. MARINI, Ruy Mauro. Subdesarollo y Revolución. México: Siglo Ventiuno Editores, 1969, p. 13.

${ }^{71}$ Idem, Dialética da dependência, op. cit., p. 121

${ }^{72}$ No que se refere ao processo de intercâmbio de mercadorias, Marini certamente não seguia os apontamentos de Marx, para quem a troca de toda e qualquer mercadoria era uma troca entre coisas de igual valor (de troca). Na verdade, sua argumentação vai ao encontro de muitas das críticas de economistas neoclássicos feitas ao autor de $O$ Capital, que argumentavam que eram os mecanismos de mercado que determinavam, em última instância, os preços e as relações de preços entre as mercadorias: “Teoricamente, o intercâmbio de mercadorias exprime a troca de equivalentes, cujo valor se determina pela quantidade de trabalho socialmente necessário que as mercadorias incorporam. Na prática, se observam diferentes mecanismos que permitem realizar transferências de valor, passando por cima das leis de intercâmbio e que se expressam na maneira como se fixam os preços de mercado e os preços de produção das mercadorias”. Idem, ibidem, p. 120, grifo nosso.

${ }^{73}$ Idem, Ibidem, p. 122. 
maneira, a depreciação dos salários dos trabalhadores era perfeitamente compatível - na verdade, era uma condição necessária - ao desenvolvimento capitalista (dependente) da América Latina.

Mas como explicar então o surgimento de um importante núcleo industrial em algumas das economias mais avançadas da região, tendo-se em vista que este processo fora realizado tendo-se como base principal a produção para o mercado interno? Marini não chega a responder esta questão ${ }^{74}$, entretanto, para ele, tratava-se de uma industrialização bastante problemática: incapaz de gerar sua própria demanda, que se expandia somente devido a ocorrência de "fatores externos”, estruturada em função das exigências de mercado dos países desenvolvidos, restrita aos setores industriais tecnologicamente menos avançados (como a siderurgia, por exemplo), e, por fim, incapaz de alterar - e na verdade, reforçando-o - o fundamento axial do capitalismo dependente, qual seja, a superexploração do trabalhador ${ }^{75}$. Dado o exíguo mercado consumidor interno sobre a qual se processava a industrialização periférica, Marini considerava que haveria um desestímulo ao investimento no setor produtivo voltado ao consumo popular (as chamadas “indústrias tradicionais”, ou o setor de bens-de-consumo não duráveis), o que, segundo ele, provocaria a sua estagnação ou até mesmo sua regressão ${ }^{76}$. Para compensar essa situação, o Estado lançaria mão de políticas fiscais, monetárias e tributárias a fim de transferir renda das classes sociais mais baixas para as camadas médias e altas responsáveis pelo consumo; o que, por sua vez, favoreceria as “indústrias de bens suntuários”, como a de automóveis ou a de eletrodomésticos. Todavia, dado os limites naturais desse tipo de medida, Marini considerava imperiosa a

\footnotetext{
${ }^{74}$ Ao que parece, o autor subscreve a tese da industrialização por substituição das importações da Cepal. Entretanto, ele não oferece maiores explicações de como compatibilizar esta tese, que pressupõe a existência de um mercado consumidor interno como poderoso indutor do crescimento industrial periférico, com suas próprias idéias, que argumentam enfaticamente pela irrelevância, ou mesmo inexistência, desse mesmo mercado: "Não cabe aqui passar a analisar o processo de industrialização na América Latina, nem menos ainda tomar o partido na atual controvérsia que nesse processo desempenhou a substituição de importações. Para os fins que nos propusemos, é suficiente fazer observar que, por significativo que tivesse sido o desenvolvimento industrial no seio da economia exportadora (e, por conseguinte, na extensão do mercado interno), em países como a Argentina, o México, o Brasil e outros, não chegou nunca a conformar uma verdadeira economia industrial que, definindo o caráter e o sentido da acumulação de capital, produzisse uma mudança qualitativa no desenvolvimento desses países”. Idem, Ibidem, p. 135-136.

75 "Dedicada à produção de bens que não entram ou entram muito escassamente na composição do consumo popular, a produção industrial latino-americana é independente das condições de salário próprias dos trabalhadores. [...] Isto dispensa o industrial de preocupar-se em aumentar a produtividade do trabalho para, fazer baixar o valor da unidade de produto, depreciar a força de trabalho e o leva, inversamente, a buscar o aumento da mais-valia através de uma maior exploração - intensiva e extensiva - do trabalhador, assim como a rebaixa de salários, mas além de seu limite normal”. Idem, Ibidem, 142.

${ }^{76}$ Idem, Ibidem, p. 148
} 
necessidade de alguns dos países da região, notadamente o Brasil, de se expandirem para o mercado externo, numa espécie de reedição da velha economia exportadora. Nesse sentido, o processo de exportação de manufaturas do Brasil para os países vizinhos, que se delineia a partir de meados dos anos 1960, será visto pelo autor como a “tábua de salvação de uma economia incapaz de superar os fatores desarticuladores que a afetam"77.

Este processo, que Marini denominou de sub-imperialismo, além das características de superexploração e sub-consumo das classes trabalhadoras, contemplava ainda os seguintes aspectos: a) a ditadura militar, que surge como uma conseqüência inevitável da crise do nacional-desenvolvimentismo e ao mesmo tempo como uma imposição frente aos desafios militares e econômicos da expansão internacional; b) a integração ao imperialismo norte-americano, visto que a única maneira da burguesia brasileira conquistar novos mercados seria por meio de uma “cooperação antagônica” com seu sócio-maior norte-americano, que em troca da parceria e do acesso aos demais mercados, exigia-lhe a maior fatia dos lucros e o controle do processo produtivo; c) e, finalmente, uma "total irracionalidade", dado pelo volume crescente de capitais e de mão-de-obra empregado no setor improdutivo da indústria bélica (nesse sentido, o Estado surge como o principal agente indutor dessa demanda irracional). ${ }^{78}$

Seguindo a linha de raciocínio que permeia os escritos dessa vertente da teoria da dependência, Marini vai defender a idéia de que a única alternativa para um verdadeiro desenvolvimento econômico, que incluísse socialmente as massas oprimidas e promovesse a expansão das forças produtivas, seria por meio do socialismo:

Para as grandes massas do povo, o problema está [...] numa organização econômica que não apenas admita a incorporação do progresso tecnológico e a concentração das unidades produtivas, mas que as acelerem, sem que isso implique em agravar a exploração do trabalho em âmbito nacional e subordinar definitivamente a economia brasileira ao imperialismo. Tudo reside em conseguir uma organização da produção que permita o pleno aproveitamento do excedente criado, isto é, que aumente a capacidade de emprego e de produção dentro do sistema, elevando os níveis de salário e de consumo. Como isto não é possível no marco do sistema capitalista, não resta ao povo brasileiro senão um caminho: o exercício de uma política revolucionária, de luta pelo socialismo ${ }^{79}$

\footnotetext{
${ }^{77}$ Idem, Ibidem, p. 150.

${ }^{78}$ Idem, Ibidem, p. 94-99.

${ }^{79}$ Idem, Ibdem, p. 102.
} 
Vê-se, assim, que, apesar das diferenças pontuais e eventuais discordâncias, as análises e concepções de Frank, Santos, Marini, e outros pensadores a eles ligados, em diversos aspectos coincidiam. Para eles, entender o capitalismo dependente passava por investigar seus grupos e classes sociais característicos (a lumpen-burguesia, o subproletariado etc.), bem como suas leis internas de acumulação e reprodução (o “desenvolvimento do subdesenvolvimento”, a superexploração, o sub-imperialismo, etc.); leis essas que apontavam para sua inviabilidade e, portanto, para sua inexorável deterioração econômica e social (daí a necessidade de regimes políticos autoritários garantidores da “ordem” e da acumulação dependente). As propostas alternativas de desenvolvimento que não contemplassem a total aniquilação dessa formação monstruosa seriam politicamente inconsistentes - e, portanto, fadadas ao fracasso - ou pior, agravariam ainda mais a precária situação vivida pelos povos marginalizados da América Latina. Por isso, apenas a revolução socialista seria capaz de por fim à dupla exploração (interna e externa) a que esses povos eram duramente submetidos; e apenas mediante a socialização dos meios de produção o desenvolvimento das forças produtivas atingiria sua plenitude, isto é, deixaria de basear-se na superexploração do trabalhador, para fundamentar-se nos avanços obtidos pelo progresso tecnológico.

Enquanto os três autores acima aludidos insistiriam na antinomia (socialismo ou fascismo) e na idéia de que a renovada investida do capital monopolista internacional nos países da região somente levaria a uma maior exploração dos trabalhadores e, consequentemente, ao esgotamento de seus respectivos mercados internos, uma outra vertente da teoria, chegaria a conclusões deveras distintas. Embora compartilhassem com aqueles muitas das referências teóricas, e rejeitassem igualmente as teorias econômicas e sociológicas da modernização, bem como a crença desenvolvimentista numa revolucionária "burguesia nacional”, os partidários dessa outra versão da teoria da dependência, aqui denominada de "heterodoxa”, fariam diagnósticos e traçariam perspectivas a respeito do capitalismo dependente da América Latina que, sob certos aspectos, eram quase opostos aos assinalados pela vertente ortodoxa. Por certo, não deixariam de criticar as conseqüências negativas ou até mesmo perversas dessa nova “situação” do desenvolvimento dependente para grandes parcelas da população, mas não confundiriam essa crítica com a suposta inviabilidade do modo capitalista de 
produção em países de desenvolvimento retardatário como o Brasil, o qual, para esses autores, vinha se diferenciando socialmente e se modernizando economicamente. 


\subsection{A Versão Heterodoxa da Dependência}

Paralelamente à constituição da versão ortodoxa da teoria da dependência, uma outra abordagem em relação ao estudos do desenvolvimento em países periféricos foi se gestando no meio da intelectualidade brasileira e latino-americana. Se bem que a obra mais importante desta vertente tenha sido elaborada em Santiago do Chile, no momento em que lá conviviam juntos pesquisadores e intelectuais de esquerda das mais distintas cepas (estruturalistas, dependentistas, neo-marxistas, trotskistas, foquistas, althusserianos etc.,), e seja, sob esse prisma, produto do ambiente intelectual da capital chilena, as origens desta vertente teórica são mais remotas, prendem-se, sobretudo, ao contexto político e intelectual de São Paulo do final dos anos cinqüenta e início dos sessenta.

De um ponto de vista mais geral, a versão heterodoxa da dependência está indissociavelmente ligada, por um lado, à chamada “Escola Paulista de Sociologia”, da qual é uma patente herdeira, e por outro, à emergência de uma nova esquerda intelectual no país. Saída principalmente dos quadros de algumas faculdades de São Paulo, essa emergente esquerda recusaria a um mesmo tempo o voluntarismo do desenvolvimento "genuinamente nacional”, e o catastrofismo estagnacionista em que boa parte da esquerda (da velha guarda desenvolvimentista aos grupos marxistas radicais) se engolfaria nos anos subseqüentes. Com efeito, a busca por uma visão mais crítica e apurada sobre a formação social brasileira constituirá o grande leitmotiv de todo um conjunto de pesquisadores insatisfeitos com o esquematismo e dogmatismo prevalecentes em grande parte das interpretações vigentes. Movidos por esse anseio, que mais tarde seria reforçado pela crítica ao regime militar, e além do mais, tendo uma formação acadêmica mais sólida e especializada que as gerações predecessoras, essa nova intelligentsia universitária iria contribuir de maneira importante para o amadurecimento das ciências sociais brasileiras, em geral, e para um melhor entendimento sobre a dinâmica, os rumos e as possíveis alternativas ao desenvolvimento econômico e social do país, em particular. Seriam produtos desse esprit de corps não apenas a versão heterodoxa da dependência, como também as chamadas teorias do populismo, da marginalidade e do autoritarismo (além é claro, de trabalhos “independentes”, mas não menos importantes) as quais, embora não fossem 
necessariamente complementares entre si, eram, sob diversos aspectos, convergentes, sobretudo na idéia de "autonomia relativa do político" ${ }^{80}$. Tendo sido provavelmente 0 mais destacado e influente pensador dessa nova geração de cientistas sociais de São Paulo, Fernando Henrique Cardoso teve um papel fundamental na elaboração, divulgação e popularização da vertente heterodoxa da dependência. Dado a centralidade de Cardoso para os desdobramentos desta versão da teoria da dependência, convém realizar uma breve reconstituição da trajetória biográfico-intelectual do autor.

Nascido no Rio de Janeiro, mas “radicado” em São Paulo, onde constituiria sua carreira acadêmica, e posteriormente, política, Fernando Henrique Cardoso iniciaria sua empreitada intelectual ainda nos anos 1950, na Faculdade de Filosofia, Ciências e Letras da Universidade de São Paulo, como um dos discípulos e jovens-assistentes de Florestan Fernandes, professor na cadeira de Sociologia I da mesma instituição. Sob a liderança de Florestan, e em conjunto com outros pesquisadores, como Octávio Ianni, Marialice Foracchi, Luiz Pereira, Maria Sylvia de Carvalho Franco, Lêoncio Martins Rodrigues, entre outros, ajudaria a constituir e a consolidar a chamada "Escola Paulista de Sociologia”. Nesse período, e até por volta do golpe de 1964, Florestan Fernandes e seu grupo batalhariam para estabelecer a "Sociologia como uma ciência empírica”, dando-lhe um caráter propriamente científico, com vistas assim a se afastar tanto do estilo “ensaísta” de explicação, prevalecente até bem pouco tempo no pensamento social brasileiro, quanto das interpretações mal disfarçadamente ideologizadas do ISEB e do PCB. A fim de institucionalizar a disciplina de Sociologia e atribuir-lhe um estatuto teórico superior em relação a esses métodos de análise e investigação considerados ultrapassados, Florestan almejava que a atuação profissional do sociólogo fosse pautada por certos princípios normativos, tais como o trabalho colaborativo interdisciplinar, as pesquisas empíricas e o rigor metodológico, bastante à maneira da Escola de Chicago, cuja influência era explícita ${ }^{81}$. Essa sua concepção de pesquisa sociológica deixaria profundas marcas no tipo de investigação, análise e interpretação que viriam a ser praticadas por seus assistentes, e talvez até pela própria Faculdade de Filosofia. Um dos primeiros e mais importantes resultados dessa empreitada intelectual viria com o projeto

\footnotetext{
${ }^{80}$ Cf. BRANDÃO, Gildo Marçal. “O revolucionário da ordem: O Brasil e a América Latina em Oliveiros S. Ferreira”. Lua Nova, São Paulo, nº48, 1999, p. 130, 1999

81 "Dadas as analogias entre Chicago e São Paulo e os nossos propósitos de expandir aqui a investigação a sociológica, a tentativa de converter São Paulo em um laboratório (ou em um campo especial de trabalho concentrado dos sociólogos) atraía o melhor da minha imaginação”. FERNANDES, Florestan. A Sociologia no Brasil. 2a . ed. Petrópolis: Vozes, 1980, p. 170 apud ARRUDA, Maria Arminda do Nascimento. “A sociologia de Florestan Fernandes”. Tempo Social, São Paulo, v. 22, nº.1, 2010, p. 17-18.
} 
encomendado pela UNESCO, e coordenado por Florestan e Roger Bastide, denominado O Preconceito Racial no Brasil, em que se pretendia aprofundar o conhecimento sobre as relações raciais do país ${ }^{82}$. Diversos trabalhos surgiriam em decorrência desse projeto $^{83}$, dentre eles a tese de doutorado de Fernando Henrique Cardoso ${ }^{84}$, defendida em 1961, sob a orientação de Florestan. Além de seu valor intrínseco enquanto trabalho de investigação historiográfica e sociológica, esta obra tem uma importância adicional para o trabalho de reconstituição das idéias aqui realizado; ela contém o "embrião" da teoria da dependência que o autor, em parceria com Enzo Faletto, viria a desenvolver alguns anos mais tarde. Voltaremos a esse assunto mais à frente.

Sem embargo, ainda durante o período de sua pesquisa de doutoramento, Cardoso e o grupo de jovens pesquisadores da Faculdade de Filosofia a ele associados iniciariam um movimento de gradativa "autonomização" frente ao antigo mestre. Simbolicamente, talvez o momento que represente o "grito de independência" daquela nova geração de cientistas sociais, tenha sido no chamado Seminário Marx, o qual Florestan não fora convidado a participar ${ }^{85}$.

Idealizado pelo filósofo José Arthur Giannotti, o Seminário funcionaria por seis anos, entre 1958 e 1964. Durante esse tempo, jovens professores, assistentes e alguns destacados alunos da Faculdade de Filosofia ${ }^{86}$ se reuniriam para ler e estudar O Capital,

\footnotetext{
${ }^{82}$ O projeto foi encomendado pela UNESCO porque se acreditava que as "relações harmoniosas entras raças" que supostamente havia no Brasil, poderiam servir de exemplo para outras partes do mundo, como os EUA ou a África do Sul. As pesquisas realizadas por Roger Bastide, Florestan Fernandes e seu grupo tratariam de desqualificar, ou pelo menos, de desmistificar essa concepção. Sobre o projeto da UNESCO vide MAIO, Marcos Chor. A História do Projeto UNESCO: Estudos Raciais e Ciências Sociais no Brasil. Rio de Janeiro: IUPERJ, 1997, tese de doutorado.

${ }^{83}$ Os resultados do projeto podem ser encontrados em diversos trabalhos publicados, como: BASTIDE, Roger; FERNANDES, Florestan. Brancos e negros em São Paulo. São Paulo: Global Editora, 2008. FERNANDES, Florestan. A integração do negro na sociedade de classes. São Paulo: Globo, 2008. CARDOSO, Fernando Henrique; IANNI, Octavio. Cor e Mobilidade Social em Florianópolis: aspectos das relações entre negros numa comunidade do Brasil Meridional. São Paulo: Companhia Editora Nacional, 1960. IANNI, Octavio. As metamorfoses do escravo. São Paulo: Difel, 1962

${ }^{84}$ CARDOSO, Fernando Henrique. Capitalismo e escravidão no Brasil Meridional: O negro na sociedade escravocrata do Rio Grande do Sul. 5a. ed. São Paulo: Civilização Brasileira, 2003.

${ }^{85}$ Em entrevista, Cardoso relata o episódio: "Florestan não gostava do seminário de Marx. [Entrevistador: Ele não quis participar?] Não. Nós também não queríamos. Era um conflito de geração. O seminário significava nossa emancipação intelectual. Também por isso Florestan tinha implicância com o tal seminário”. In: BASTOS, Elide Rugai et al (Org.). Conversas com sociólogos brasileiros. São Paulo: Editora 34, 2006, p.77

${ }^{86}$ Além de Gianotti e Cardoso, o Seminário contaria ainda com as participações de nomes que se tornariam figuras de destaque nas ciências sociais brasileiras, tais como Octavio Ianni, Fernando Novais, Paul Singer, Bento Prado Jr., Roberto Schwarz, Francisco de Oliveira, Francisco Weffort, Ruth Cardoso, Michael Löwy e diversos outros.
} 
algumas outras obras importantes do marxismo ${ }^{87}$, e até mesmo autores como Keynes e Weber. Havia entre os participantes do Seminário dois objetivos principais na leitura daqueles textos clássicos. O primeiro era o de prover um instrumental teórico que servisse de subsidio para se pensar questões contemporâneas e prementes, como as rápidas transformações socioeconômicas ou o intenso processo de industrialização, pelas quais o país, e São Paulo em particular, atravessavam. Conforme sustenta Gianotti: “O problema era pensar o Brasil, o que estava acontecendo no país, como seria possível engatar o desenvolvimento [...] Nosso problema era a modernidade: como transformar esse país provinciano num país moderno” ${ }^{88}$. O segundo grande objetivo, e talvez o mais explícito dentro do grupo, era o de revalorizar o marxismo como uma disciplina acadêmica e científica, resgatando-o assim das limitações analíticas a que fora submetido pelo marxismo "oficial”, o do PCB. A despeito do revigoramento intelectual pelo qual passava o marxismo na Europa e nos EUA - quiçá, o seu último período de grande influência nas ciências sociais dos países centrais - enriquecido que era pelas originais contribuições de intérpretes como Lukács, Sartre, Gramsci (que morrera em 1937, mas cujos famosos Cadernos seriam publicados apenas após a Segunda Guerra Mundial), pela escola de Frankfurt e inúmeros outros autores influentes, consumia-se ainda no país um marxismo muito pobre e esquemático - notória exceção feita a Caio Prado Jr. - que tinha lá alguma utilidade para fins de mobilização política, mas que no campo propriamente científico, isto é, para efeitos de uma efetiva compreensão e interpretação da realidade político-social brasileira, antes lhe tolhia o horizonte do que lhe proporcionava novos e profícuos insights. Era justamente essa cultura marxista de manual que o Seminário visava e iria, de fato, abalar, como bem lembra um de seus participantes, o sociólogo Roberto Schwarz: “[...]a ligação deliberada da leitura de $O$ Capital ao motor da pesquisa universitária iria modificar o quadro e deixar a cultura marxista anterior em situação difícil. No essencial, o desnível indicava regimes diferentes de reflexão social, dos quais um se estava tornando anacrônico”89. Com efeito, o encontro da pesquisa acadêmica com uma leitura mais “arejada” do marxismo, ajudada que era pelas instigantes reflexões trazidas pelos intérpretes acima

\footnotetext{
${ }^{87}$ Segundo relatos de seus participantes, além da obra capital de Marx e Engels, lida em todos seus tomos, o Seminário ainda se debruçaria sobre o 18 Brumário, Crítica da Economia Política, Manuscritos Econômicos e Filosóficos, e ainda sobre autores marxistas de enorme influência naquele período, como Lukács e Sartre.

${ }^{88}$ Entrevista de José Arthur Giannotti em MONTERO, Paula; MOURA, Flávio (Orgs.). Retrato de Grupo - 40 Anos do Cebrap. São Paulo: Cosac Naify, 2009, p.55-56

${ }^{89}$ SCHWARZ, Roberto. “Um seminário de Marx”. In: Seqüências Brasileiras. São Paulo: Companhia das Letras, 1999, p. 90
} 
mencionados, marcaria a produção intelectual daqueles jovens pesquisadores e influenciaria os próprios rumos do marxismo no país, obliterando a tradição hegemônica anterior.

Para os participantes do Seminário em geral, e para Fernando Henrique Cardoso em particular, a participação no Seminário representaria a incorporação da dialética marxista ao seu repertório teórico-metodológico, em prejuízo mesmo de outras linhagens do pensamento, em especial, o funcionalismo, o que geraria atritos com Florestan Fernandes, cuja tese de livre-docência tivera como tema justamente o Método de Interpretação Funcionalista na Sociologia ${ }^{90}$. Além disso, como é sabido, o patrono da Cadeira de Sociologia I tinha uma concepção muito particular a respeito da pesquisa sociológica - “compartimentada” diríamos -, isto é, para ele, havia uma clara divisão de tarefas no estudo dos diferentes tipos de fenômenos histórico-sociais, cada qual exigindo uma abordagem e um instrumental analítico específicos: o funcionalismo, para o exame de fenômenos sociais de longa-duração e certa regularidade supra-histórica (segundo os diferentes tipos de sociedade); o weberianismo, quando o assunto fossem as “regularidades universais da vida social”; e o marxismo, ou o método dialético, para o estudo das "alterações dos padrões da ordem social”" 91 . Mais importante que esta divisão em si mesma, é que para Florestan, “[...] nenhuma das modalidades de Sociologia tinha, intrinsecamente, superioridade cognitiva sobre as demais. Simplesmente, destinavam-se a lidar com problemas e produziam conhecimentos distintos, embora complementares" ${ }^{92}$. Por seu turno, os participantes do seminário tendiam a negar essa divisão "tripartite” da Sociologia, considerada “demasiada cientificista”, e a situar o marxismo numa posição hierarquicamente superior aos outros métodos de investigação. Com efeito, no contexto social de grande agitação política e agudas mudanças econômicas e sociais daquele período, havia entre a jovem intelectualidade da Faculdade de Filosofia um clima de animosidade, e até de certa reprovação, a teorias sociológicas cujo foco ou primazia analítica residia na estabilidade social, como era ou se supunha ser o funcionalismo; o que, por contraste, trazia o marxismo para o centro do debate: “O Brasil entrava por um processo de radicalização, e a reflexão sobre a

\footnotetext{
${ }^{90}$ Cf. FERNANDES, Florestan. "Ensaio sobre o método de interpretação funcionalista em Sociologia". Boletins da Faculdade de Filosofia, Ciências e Letras, no 170, São Paulo: Faculdade de Filosofia, Ciências e Letras, 1953.

${ }^{91}$ A esse respeito, veja-se FERNANDES, Florestan. Fundamentos empíricos da explicação sociológica. São Paulo: Editora Nacional, 1959.

${ }_{92}$ SALLUM JR., Brasilio. "Notas sobre o surgimento da Sociologia Política em São Paulo". Política \& Sociedade, Florianópolis, v. 1, nº. 1, 2002, p. 77.
} 
dialética [marxista] e a luta de classes parecia sintonizar com a realidade, ao contrário das outras grandes teorias sociais, mais voltadas para a ordem e o equilíbrio do que para a transformação" 93 .

Afora a participação no Seminário que, como veremos, teria grande influência em sua tese de doutorado, outros acontecimentos importantes naquele período viriam a marcar a trajetória de Cardoso. Por sugestão do sociólogo francês Alain Touraine, quando de sua passagem por São Paulo no inicio dos anos sessenta, Florestan Fernandes e Fernando Henrique fundariam, em 1962, o Centro de Sociologia Industrial e do Trabalho - CESIT. Sob a direção dos dois, e congregando alunos recém-formados da Faculdade de Filosofia, o CESIT marcaria a mudança do leque temático preferencial da sociologia uspiana. Se até aquele momento as pesquisas no âmbito da cadeira de Sociologia I haviam se concentrado em temas como o negro, o caipira, o imigrante, o folclore, a religião popular etc. - tópicos “anti-aristocráticos” que espelhavam aquele “pensamento radical de classe média” de que fala Antonio Candido ${ }^{94}$ - a partir daí, voltar-se-iam preferencialmente à “mudança social”, ao Estado, ao empresariado industrial, ao operariado, enfim, aos processos e atores que estavam no centro nervoso do processo de desenvolvimento nacional ${ }^{95}$. Com isso, o grupo entraria de vez num debate que se concentrava em boa medida no Rio de Janeiro, muito em função do centro político do país orbitar, à época, a capital fluminense ${ }^{96}$. Baseando-se fartamente no uso de dados empíricos e em pesquisas de campo, os estudos realizados no âmbito do CESIT evidenciariam a ausência de fundamentação factual de muitas das principais premissas da ideologia nacional-desenvolvimentista. O primeiro trabalho realizado no centro seria a pesquisa de livre-docência de Cardoso, intitulado Empresário Industrial e

\footnotetext{
${ }^{93}$ SCHWARZ, Roberto, op. cit., p. 89.

${ }^{94}$ CANDIDO, Antonio. "Entrevista”. In: Brigada Ligeira e outros escritos. São Paulo: Unesp, 1992, p. 233-235.

${ }^{95} \mathrm{O}$ projeto global de investigações encontra-se detalhadamente descrito em FERNANDES, Florestan. "Economia e Sociedade no Brasil: análise sociológica do subdesenvolvimento". In: A Sociologia numa era de Revolução Social. São Paulo: Cia. Editora Nacional, 1963, p.300-325. Veja-se também o capítulo seguinte, "A empresa industrial em São Paulo", em que Florestan e Cardoso expõem o arcabouço teórico e metodológico do plano de estudos que resultaria na tese de livre docência do último.

96 “Até o final dos anos 50, o principal pólo de produção de idéias e projetos políticos, tanto da esquerda como da direita brasileira, estava situado no Rio de Janeiro, que continuava sendo o eixo político da República, mesmo depois da inauguração de Brasília. Afinal, era lá que estavam tanto o Instituto Superior de Estudos Brasileiros (ISEB), como o Banco Nacional de Desenvolvimento Econômico (BNDE) e até mesmo a sede do Partido Comunista Brasileiro (PCB) e de outros partidos, ao lado da Fundação Getúlio Vargas e das primeiras Faculdades de Economia, Sociologia e Política do País. Era no Rio de Janeiro que se localizavam os principais meios de comunicação do País, como rádios, jornais, editoras e outros centros de repercussão de idéias.” MANTEGA, Guido. Teoria da dependência revisitada: um balanço crítico, op. cit., p. 29-30.
} 
Desenvolvimento Econômico no Brasil ${ }^{97}$, que, dado o teor do estudo e de suas conclusões, pode ser considerado como um dos primeiros trabalhos empíricos sobre o tema da dependência, embora ainda restrito ao caso brasileiro.

No ano de 1964, com o golpe militar no Brasil, Cardoso se vê obrigado a se exilar do país a fim de evitar sua eminente prisão. Seu destino, após breve passagem pela Argentina, seria a capital chilena, que, conforme vimos no capítulo anterior, servira como uma espécie de refúgio para inúmeros intelectuais de esquerda expulsos ou perseguidos por diversos governos nacionais da América Latina. Em Santiago, Fernando Henrique tornar-se-ia professor da FLACSO e da Faculdade de Economia do Chile, além de vir a ser diretor-adjunto do Instituto Latinoamericano de Planejamento Econômico e Social - ILPES (instituição vinculada à Cepal), convidado que fora pelo sociólogo espanhol José Medina Echevarría, um dos “responsáveis” pela guinada sociológica da Cepal a partir dos anos 1960. No ILPES, Cardoso seria colega de outro jovem pesquisador que teria grande importância para a versão heterodoxa da dependência, o sociólogo e historiador chileno, Enzo Faletto.

Tendo pertencido à primeira geração de estudantes de pós-graduação da FLACSO, ainda no final dos anos cinqüenta, Faletto seria conduzido ao ILPES logo de sua inauguração, em 1962, também por influência de Echevarría, com quem vinha realizando estudos sociológicos acerca do desenvolvimento da América Latina desde o começo daquela década. Juntos, Cardoso e Faletto começariam a escrever sobre o tema da dependência a partir de 1965, e entre 1966 e 1967 redigiram aquela que se tornaria a obra mais importante desta vertente da teoria da dependência, o hoje clássico Dependência e Desenvolvimento na América Latina ${ }^{98}$. Redigido originalmente sob a forma de um relatório interno dirigido a Raúl Prebisch, o texto trazia uma interpretação sociológica do processo de desenvolvimento de vários países da região, e ao mesmo tempo, uma avaliação crítica das análises “economicistas” como as da Cepal, que consideravam que a passagem do subdesenvolvimento ao desenvolvimento dar-se-ia mediante a consecução de fatores puramente econômicos (diversificação da estrutura produtiva, capitalização dos setores agrários atrasados, moderado protecionismo comercial etc.), desconsiderando assim o arranjo de poder que tornaria possível realizar

${ }^{97}$ CARDOSO, Fernando Henrique. Empresário Industrial e Desenvolvimento Econômico no Brasil. $2^{\mathrm{a}}$. ed. São Paulo: Difusão Européia do Livro, 1972.

${ }^{98}$ CARDOSO, Fernando Henrique; FALETTO, Enzo. Dependência e Desenvolvimento na América Latina: ensaio de interpretação sociológica. 9ª ed. Rio de Janeiro: Civilização Brasileira, 2010. 
esse salto qualitativo. Na verdade, conforme seus autores argumentam, o estudo não pretendia negar a importância do esquema analítico estruturalista, mas objetivava leválo adiante, mediante a incorporação de elementos flagrantemente ausentes no modelo cepalino, como os componentes político-sociais do processo de desenvolvimento, realizando assim o que os autores denominavam de análise integrada ou global do desenvolvimento.

Dado o teor crítico do livro sobre o tipo de desenvolvimento engendrado na América Latina e, conseqüentemente, sobre as forças políticas nacionais que conduziam às diversas situações de dependência aí verificadas, a direção do ILPES recusou-se a publicar-lho $^{99}$, o que viria a acontecer apenas dois anos mais tarde, em 1969, pela editora mexicana Siglo XXI. A imediata e ampla repercussão da obra ${ }^{100}$, que ganharia edições em mais de dez diferentes línguas e tornar-se-ia referência obrigatória nos principais programas de pós-graduação sobre América Latina pelo mundo, conferiria grande prestígio aos seus autores que, não obstante, tomariam rumos distintos. Faletto sairia do ILPES em 1969, para acompanhar mais de perto a vida política chilena; regressaria pouco tempo depois ao "mundo acadêmico”, permanecendo em seu país mesmo após o golpe de Pinochet, mas abordaria poucas vezes o tema da dependência nos anos seguintes ${ }^{101}$. Já Fernando Henrique optaria por regressar a seu país de origem, após breve passagem pela França ${ }^{102}$, em 1968, a fim de concorrer à cátedra de Ciência Política da USP, pela qual seria aprovado. Pouco tempo após passar no concurso,

\footnotetext{
${ }^{99}$ Essa recusa provavelmente teve o dedo de Prebisch, que, cerca de dez anos antes e pelos mesmos motivos (o conteúdo político do texto), recusara-se a publicar um estudo de Celso Furtado sobre o México.

${ }^{100} \mathrm{Em}$ termos estritamente quantitativos, em uma pesquisa realizada no Google Scholar, Ted Goertzel constata que, com 2.606 citações, o ensaio dos sociólogos é provavelmente "o livro com mais citações no campo dos estudos sobre a América Latina, ultrapassando Capitalism and underdevopment in Latin America, de Gunder Frank, com 991 citações, e The economic development of Latina America, de Raúl Prebisch, com 727". GOERTZEL, Ted. "Lembrem-se de tudo que escrevi: O impacto de Fernando Henrique Cardoso sobre as ciências sociais”. In: D'INCAO, Maria Angela; MARTINS, Hermínio (Orgs.). Democracia, crise e reformas: estudos sobre a era Fernando Henrique Cardoso. São Paulo: Paz e Terra, 2010, p.424; Já Simon Schwartzman, numa enquete feita com 50 grandes cientistas sociais do país, a fim de investigar quais os livros brasileiros considerados os mais importantes do século XX, revela que, se do ponto de vista do mérito Dependência e Desenvolvimento não se equiparava a outros clássicos do pensamento social brasileiro, como Formação Econômica do Brasil, Casa Grande e Senzala, Raízes do Brasil, Formação do Brasil Contemporâneo, Os Donos do Poder, e outros, em termos de influência, o ensaio de Cardoso e Faletto era considerado como estando em pé de igualdade com as supracitadas obras. SCHWARTZMAN, Simon. "As ciências sociais brasileiras no século 20". Ciência Hoje, abr., 2000. Disponível em: <http://www.schwartzman.org.br/simon/10mais.htm>.

${ }^{101}$ Sobre isso, veja-se REGO, José Marcio. "Entrevista com Enzo Faletto”. Tempo Social, São Paulo, vol.19, n.1, 2007, p. 215-221

${ }^{102}$ Por convite de Alan Touraine, Cardoso partiria, ainda em 1967, para dar aulas na França, numa nova faculdade da Universidade de Paris-X.
} 
entretanto, Cardoso teria sua carreira universitária na Faculdade de Filosofia novamente interrompida pelo regime militar, dessa vez permanentemente, a partir do decreto de sua aposentadoria compulsória em abril de 1969, com o Ato Institucional nº5. Vários professores ligados à esquerda teriam o mesmo destino de Cardoso, entre eles Octavio Ianni e Florestan Fernandes, pouco importando no caso que quase nenhum deles tivesse então qualquer atividade político-partidária.

A fim de continuar no Brasil e manter uma porta aberta para as pesquisas em ciências sociais em São Paulo, que, em razão do afastamento de muitos dos principais professores pelos militares, se via bastante debilitada, Fernando Henrique lograria obter um financiamento junto à Fundação Ford para fundar o Centro Brasileiro de Análise e Planejamento - Cebrap. O Cebrap teria um papel fundamental durante a ditadura, particularmente em seus “anos de chumbo”: seria uma das poucas instituições ativas de pesquisa em ciências sociais no país, abrigando diversos pesquisadores cassados ou perseguidos pelo regime militar. Durante os anos 1970, o Cebrap realizaria diversos estudos seminais sobre a marginalidade urbana, o autoritarismo, os movimentos sociais, o desenvolvimento territorial etc. ${ }^{103}$. O instituto também tem uma importância adicional na carreira do sociólogo. É nele que Cardoso mudaria o seu rol de preocupações e temas de investigação: dos estudos sobre a dependência e o desenvolvimento, para os estudos sobre o autoritarismo e a democratização, e destes para a carreira política, na qual seria virtualmente absorvido a partir do final dos anos 1970 em diante.

Feito essa sumaríssima reconstituição biográfico-intelectual da carreira de Fernando Henrique, vejamos agora como a temática da dependência aparece nos escritos do sociólogo. Como afirmamos anteriormente, os primeiros passos de Cardoso na constituição de uma teoria da dependência seriam dados em sua pesquisa de doutorado, realizada entre 1955 e 1960. Não se pretende afirmar com isso que a obra em si constitua o marco inicial dos estudos sobre a dependência em sua carreira - o que seria um anacronismo. A rigor, a pesquisa aborda o tema das origens histórico-sociais e econômicas da dependência no Brasil (colonialismo, escravismo, patriarcalismo etc.),

\footnotetext{
${ }^{103}$ Dentre os vários trabalhos expressivos realizados no âmbito do Cebrap, um dos de maior expressão sem dúvida foi a obra coletiva São Paulo 1975: crescimento e pobreza, um dos primeiros e mais importantes estudos sobre acumulação capitalista e marginalidade urbana na maior metrópole do país. Cf. CAMARGO, Cândido Procópio Ferreira de (Org.). São Paulo 1975: crescimento e pobreza. São Paulo: Loyola, 1976.
} 
mas a caracterização do quadro conceitual que envolve esta noção seria realizada explicitamente apenas alguns anos mais tarde, em Santiago do Chile. Sem embargo, alguns dos fundamentos teóricos e metodológicos presentes nesse trabalho, especialmente a dialética marxista, ou melhor, o entendimento que o autor tinha desta, seriam em larga medida retomados em suas análises posteriores sobre o desenvolvimento e a dependência na América Latina ${ }^{104}$. Por isso, compreender a maneira como o autor entende e trabalha este conceito, exaustivamente explorado em Capitalismo e Escravidão, talvez possa ajudar no exame e interpretação de seus estudos seguintes.

Um dos objetivos centrais de sua pesquisa de doutorado, e nisso Fernando Henrique seguia de perto seu orientador, Florestan Fernandes, era o de rechaçar o “mito” da democracia racial, atribuído pela sociologia uspiana à Gilberto Freyre ${ }^{105}$. Não à toa, era atribuída tanta importância às pesquisas empíricas: por meio de entrevistas, leitura de documentos históricos e oficiais, consulta a jornais da época, etc., visava-se a reconstituição histórica de um sistema econômico que tinha como fundamento social axial - e, por sinal, bastante evidente - a violência, que "bestializava” os escravos e “alienava” os próprios senhores (nada mais longe, portanto, da idílica idéia de uma “democracia racial”).

\footnotetext{
${ }^{104} \mathrm{O}$ próprio autor admite em entrevistas, e no prefácio das edições mais recentes de Capitalismo $e$ Escravidão, que o método de análise utilizado naquela pesquisa seria o mesmo que o utilizado mais tarde em Dependência e Desenvolvimento. Segundo Cardoso, o próprio prefácio da edição inglesa deste último livro "[..] contém uma complicada (e, aos olhos de hoje, desnecessária) explicação do método utilizado. Quem reler aquele texto verá que voltamos à Introdução do livro sobre capitalismo e escravidão no Brasil Meridional, e que o resgate do marxismo de sua versão vulgar se fez saturando os conceitos de historicidade”. CARDOSO, Fernando Henrique; FALETTO, Enzo. op. cit, p. 9-10, grifo nosso.

${ }^{105}$ Embora a expressão "democracia racial” seja amplamente creditada a Gilberto Freyre, não há, segundo Antônio Sérgio Guimarães, em suas obras principais qualquer menção ao termo. Mesmo considerando-se tão-somente a idéia, e não a expressão em si mesma, ou seja, a noção de uma sociedade pautada pela igualdade de oportunidades entre brancos e negros, pela harmonia social entre as raças, pela ausência de preconceito de cor, etc., ainda assim, ela não pode ser inteiramente atribuída ao sociólogo pernambucano. A criação do mito da democracia racial, bem como a crítica à essa noção, foi, segundo o autor, antes a conseqüência da interpretação da obra freyriana em contextos históricos e sociais marcadamente politizados, nos quais o notório conservadorismo de Freyre (não nos esqueçamos que ele fora um entusiasta do golpe militar de 1964) certamente contribuiu para seu "achincalhamento" pelas novas gerações. Cf. GUIMARÃES, Antônio Sergio. "Racial democracy”. In: SOUZA, Jessé; SINDER, Vander (orgs.). Imagining Brazil. Lanham: Lexington Books, 2005, p. 119-140. A reabilitação de Freyre nos últimos anos, como um dos grandes intérpretes do Brasil - se bem que autores como Antonio Candido nunca tenham deixado de considerá-lo como tal - é sintomático daquela atmosfera "politizada" em que sua obra foi - talvez excessivamente - criticada. Leia-se, por exemplo, a transcrição da aula magna de Fernando Henrique Cardoso no Instituto Rio Branco, em que o autor fala sobre a importância e sobre o "papel revolucionário" de Gilberto Freyre nas ciências sociais brasileiras. Cf. CARDOSO, Fernando Henrique. "Livros que inventaram o Brasil”. Novos Estudos Cebrap, São Paulo, n³7, 1993, p.21-35.
} 
Se num plano geral, o farto emprego da pesquisa empírica podia ser atribuído à orientação de Florestan, e de sua pretensão em desmistificar as concepções idealizadas, quando não simplesmente falsas, a respeito da escravidão, o mesmo não pode ser dito a respeito da crítica que Cardoso fizera na introdução de seu estudo ao método funcionalista $^{106}$, assim como sua utilização da dialética marxista; esta última, em grande medida resultado das leituras e discussões que Fernando Henrique tivera no "Seminário Marx”. Embora não seja correto afirmar que Florestan negligenciasse a importância do marxismo para a análise de processos sociais (ao contrário, conforme vimos, ele o considerava como um dos três pilares fundamentais da pesquisa sociológica), naquele momento específico, de construção e consolidação de uma metodologia propriamente científica no campo das ciências sociais, sua intenção era a de evitar que as interpretações de seus discípulos enveredassem para uma abstração puramente teórica, no qual aquele instrumental, enriquecido pelas ricas, porém “ensaístas” interpretações de Lukács e Sartre, certamente poderia levar (e que em parte levou, como o próprio Cardoso reconheceria muitos anos mais tarde ${ }^{107}$ ). Sem embargo, o emprego de autores que repaginavam o marxismo tinha um propósito analítico bem claro e especifico para Fernando Henrique - e que seria a tônica de muitos de seus próximos trabalhos - isto é, o de contrapor-se às interpretações mecanicistas do "marxismo vulgar”: através do uso combinado de conceitos derivados do próprio Marx, Sartre e Lukács e outros autores, visava-se reconstituir dialeticamente uma estrutura socioeconômica altamente complexa, que nada tinha a ver com o velho feudalismo europeu e que, a rigor, também não era um modo capitalista de produção, embora fosse articulado, e até certo período, funcional à sua expansão, isto é, o "sistema escravista”.

Pois bem, qual era então sua concepção sobre o método marxista-dialético e como ele o empregava no esquema analítico? Há, segundo pensamos, três aspectos

\footnotetext{
${ }^{106}$ Fernando Henrique comenta que, por conta dessas críticas, a versão preliminar da tese fora recusada por Florestan. Se bem que Cardoso cogitara mudar de orientador, ao final ele amenizou parte daquelas críticas e continuou sob a orientação de Florestan (Vide o depoimento de Cardoso em BASTOS, Elide Rugai et al., op. cit., p. 77). Ainda assim, a versão que foi publicada não deixa de conter importantes restrições do autor quanto às limitações desse método de análise em questão.

${ }^{107}$ No prefácio da edição de 2003 do livro, Fernando Henrique, numa mea culpa, admite: “[...] talvez a insistência nas diferenças entre a situação de escravo e a de proletário (aliás, óbvia) possa ter ficado um tanto confusa com a reiteração dos conceitos de Lukács. Não por acaso, Florestan Fernandes temia, quando iniciamos o "Seminário de Marx", que a leitura de Lukács distorcesse as “análises empíricas”. Na ocasião, as observações do mestre surpreenderam-me. Hoje, entendo sua posição: o brilhantismo filosófico de Lukács poderia levar-nos a análises mais abstratas e conceituais do que à reconstrução histórico-estrutural dos processos que pretendíamos esclarecer". CARDOSO, Fernando Henrique. Capitalismo e escravidão no Brasil Meridional: O negro na sociedade escravocrata do Rio Grande do Sul. 5a. ed. São Paulo: Civilização Brasileira, 2003, p. 11.
} 
normativos da "explicação dialética" que o autor explicita na introdução de Capitalismo e Escravidão, e que reaparecerá constantemente em seus próximos estudos, ao menos como princípios metodológicos. Em primeiro lugar, para Cardoso, a dialética marxista fornecia um instrumental teórico que permitia apreender nada menos que o funcionamento global da sociedade, as determinações essenciais que condicionam o padrão da estrutura social e dão um sentido de organicidade às suas partes, e que, portanto, permitem caracterizar a totalidade histórica (ou social) concreta:

Na explicação dialética o conceito de totalidade é utilizado como um recurso interpretativo pelo qual se visa compreender, como Marx escreveu explicitamente no posfácio da Contribuição à Crítica da Economia Política, não a identidade, o padrão da invariância, mas as diferenças em uma unidade, tal como são engendradas numa totalidade determinada. Desse ângulo [...] a abordagem totalizadora transforma-se numa perspectiva de interpretação para a análise de cada um e de todos os fenômenos sociais. A totalidade assim entendida pressupõe não apenas a existência de diferenças numa unidade, mas também a existência de conexões "orgânicas” que explicam, ao mesmo tempo, o modo de inter-relacionamento existente entre as determinações que constituem as totalidades e o próprio processo de constituição das totalidades. ${ }^{108}$

Para determinar essa totalidade concreta não bastava, contudo, examinar os determinantes abstratos e gerais, que produziriam efeitos sociais empíricos e particulares. Ao contrário, ressalta Cardoso, na análise do concreto é justamente o particular que interessa, pois “[...] são exatamente as determinações específicas que, na medida em que diferenciam as totalidades, se constituem como chave da interpretação" ${ }^{109}$. O exemplo clássico que o autor retoma de Marx para elucidar este ponto é o da vinculação entre a forma lucro e o conceito de mais-valia ${ }^{110}$. Inspirado pela dialética hegeliana, porém subvertendo-a com sua concepção materialista, Marx ao mesmo tempo em que define a determinação mais essencial e geral do modo de produção capitalista (a valorização do capital através da exploração da mais-valia), desvenda também sua manifestação concreta e “transfigurada”, isto é, a forma lucro. A totalidade é dada, nesses termos, tanto pela definição do conceito abstrato - que está fora da representação social dos atores, e portanto, do nível do real - quanto pela caracterização de sua aparência empírica, ou melhor, é dada pela relação entre esses dois planos. Assim, a interpretação materialista-dialética desdobra-se em dois planos

\footnotetext{
${ }^{108}$ CARDOSO, Fernando Henrique, op. cit., p. 29, grifos do autor.

${ }^{109}$ Idem, Ibidem, p. 48

${ }^{110}$ Idem, Ibidem, p. 33 et seq.
} 
analíticos distintos, porém interdependentes: o plano conceitual e geral, no qual são definidas as categorias explicativas da estrutura e funcionamento da sociedade (a maisvalia, a relação capital-trabalho etc.); e o plano do singular, da realidade empírica, enfim, o da totalidade concreta, no qual aqueles conceitos são utilizados para explicar e dar inteligibilidade ao curso do real, mas que não reduzem o último a uma mera conseqüência de esquemas abstratos dados a priori. Nesse sentido - e Fernando Henrique insistirá muitas vezes nesse ponto ao longo de sua trajetória intelectual - é o concreto que deve ser o foco privilegiado da análise, pois embora este plano vincule-se às determinações mais gerais e abstratas (do capitalismo, da divisão internacional do trabalho, da relação entre as classes etc.), possui uma dinâmica, se não ao menos própria, diversa daquela:

[...] a análise dialética não se pode contentar com a reafirmação da existência de existência de oposições gerais (dominadores e dominados, senhores e escravos, patrões e operários); ela deve buscar na particularização destas formas o sentido preciso e as possibilidades de ação (dos movimentos sociais, da práxis) que explicam a qualidade diferencial de cada grande situação histórica. Para caracterizar dialeticamente uma "totalidade histórica" concreta é preciso relacionar o geral com o singular e ver as relações estruturadas e hierarquizadas que as ligam e a diferenciam, ao mesmo tempo. ${ }^{111}$

Em segundo lugar, a dialética é importante para o autor porque ela proporciona a perspectiva analítica da contradição, do movimento dinâmico de forças antagônicas que, ao se confrontarem, geram transformações. Como se trata de dialética marxista, esse movimento é sempre referenciado às estruturas sociais. No entanto, para nosso autor, essas estruturas não deviam ser concebidas como “estáticas” e que se modificavam em virtude de uma dinâmica “independente”, ao contrário, o impulso para as modificações, as tais "possibilidades estruturais", estavam inscritas no próprio seio da sociedade, eram alternativas históricas postas à mesa dos atores coletivos, mas que para se efetivarem como realidade social, dependiam da ação política transformadora. Portanto, se, por um lado, a dialética fornecia uma ferramenta analítica apropriada para retratar os condicionantes globais e particulares da sociedade, por outro lado, ela proporcionava um método de análise para transformações histórico-estruturais que ocorriam devido às próprias tensões e acomodações que se estabeleciam no interior de cada sociedade. Novamente, embora Cardoso reconhecesse a importância das contradições gerais (e,

${ }^{111}$ Idem, Ibidem, p. 21 
óbvias) entre classes ou sistemas sociais (escravos e senhores, capitalismo e escravismo etc.), eram as oposições particulares de cada situação histórica específica que ele considerava serem os elementos analíticos mais importantes, já que era por meio de seus aspectos objetivos (a contradição real entre interesses e objetivos antagônicos) e subjetivos (a manifestação "mistificada” ou ideológica que os atores sociais têm do mundo) que o processo social ganhava vida.

Por fim, ao contrário de uma visão puramente formalista que a fórmula dialética (tese-antítese-síntese) poderia subscrever, postulando um caráter necessário para as transformações históricas e retirando deles sua dinâmica intrínseca, para Cardoso o uso da dialética só tinha alguma validade conquanto retratasse os acontecimentos históricos não como inevitáveis ou unidirecionais, mas como resultado da escolha dos homens, aberto, portanto, às diversas alternativas que são socialmente criadas por eles. Nesse sentido, o aspecto inexorável ou fatalista do processo histórico torna-se apenas aparente: em seu curso real, as opções que de fato materializam-se, apresentam-se como meras possibilidades, ou, em muitos casos, como opções meramente contingentes. É por isso que para o autor, o fim do sistema escravista - em si mesmo, uma particularização das determinações mais gerais e abstratas do modo capitalista de produção - embora houvesse se tornado no Sul do país, e posteriormente no Brasil como um todo, um requisito necessário para o aumento da produtividade geral da economia e para a constituição de um regime de acumulação propriamente capitalista, vale dizer, fundamentado na compra e venda de força-de-trabalho, se deu concretamente apenas mediante as oposições e choques de interesses inscritas no âmbito mesmo da sociedade e que, ao fim e ao cabo, sepultaram o antigo regime. Sem embargo, a nova configuração estrutural que suplanta e erige-se a partir da antiga não deixava de conter elementos ou resquícios da velha estrutura social, como o fenômeno do preconceito, por exemplo ${ }^{112}$.

Sem se estender demais nesta obra pré-dependendista de Fernando Henrique Cardoso, fica patente no breve apanhado sobre a concepção do método dialético para o autor, que seu principal objetivo na utilização do instrumental marxista era o de fornecer categorias analíticas de reflexão, ou se quiser a inspiração teórica, para se evitar o mecanicismo e o formalismo presentes em muitas das interpretações correntes naquele

\footnotetext{
${ }^{112}$ Idem, Ibidem., p.354
} 
período, que derivavam de certas leis gerais ou esquemas abstratos construídos a priori, o fundamento último (ou primeiro) da dinâmica histórica.

Se em Capitalismo e Escravidão Fernando Henrique havia resgatado da tradição marxista heterodoxa, boa parte da fundamentação metodológica na qual se baseariam seus estudos posteriores sobre o problema do subdesenvolvimento na América Latina, no plano propriamente analítico, um primeiro e fundamental passo do autor na constituição de uma teoria da dependência viria com sua tese de livre docência sobre o Empresário Industrial e Desenvolvimento Econômico no Brasil.

Assim como sua tese de doutorado, Empresário Industrial também é resultado de uma pesquisa eminentemente empírica, só que ao invés de situar-se num período histórico remoto, a escravidão, e num pólo relativamente marginal do sistema, o Sul do país, daquela vez a pesquisa versaria sobre um processo econômico coetâneo, a industrialização, e com foco especial na região onde esse processo se realizava com maior intensidade, São Paulo. O objetivo principal do autor nesse estudo era o de realizar uma análise sociológica do processo de industrialização do país, a partir da caracterização da mentalidade, ideologia, interesses e objetivos dos agentes sociais que supostamente liderariam esse processo, isto é, os empresários industriais. Para tanto, Fernando Henrique e sua equipe no CESIT realizaram um survey em empresas de diferentes portes da Grande São Paulo e algumas entrevistas em profundidade com empresários de grandes indústrias de cinco grandes cidades brasileiras. Se bem que o estudo traga uma ampla discussão sobre o papel do empresariado moderno e sobre as características do "novo capitalismo”, fazendo uma crítica a autores funcionalistas, como Talcott Parsons ${ }^{113}$, e da economia e sociologia do desenvolvimento, como W.W. Rostow $^{114}$ e Bert Hoselitz ${ }^{115}$ - críticas que, no geral, incidiam sobre a maneira "formalista" e "abstrata” com que esses autores analisavam a questão das transformações econômicas e sociais - são as conclusões que Cardoso tira das entrevistas com os empresários que ganhariam maior repercussão e fundamentariam a perspectiva desenvolvida alguns anos mais depois em seus estudos sobre a dependência.

\footnotetext{
${ }^{113}$ PARSONS, Talcott. The social system. Londres: Tavistock Publications, 1952

${ }^{114}$ ROSTOW, Walt Whitman. The process of economic growth. New York: Norton, 1952. E também o seu grande clássico: Etapas do desenvolvimento econômico - um manifesto não comunista, op. cit. .

115 HOSELITZ, Bert F. Sociological aspects of economic growth. Illinois: The Free Press of Glencoe, 1960. Vide CARDOSO, Fernando Henrique, O empresário industrial e desenvolvimento econômico no Brasil. 2a . ed. São Paulo: Difusão Européia do Livro, 1972, cap. II.
} 
Em linhas gerais, Fernando Henrique aponta para a impossibilidade de se promover no país um desenvolvimento econômico ancorado no protagonismo “nacional-burguês” dos empresários industriais, conforme sustentava a ideologia do nacional-desenvolvimentismo. Baseado nas entrevistas com os dirigentes industriais, e também no exame de seu perfil socioeconômico, o autor conclui que a vasta maioria dos empresários não objetivavam, e nem tinham capacidade efetiva para tanto, realizar uma “revolução burguesa” em aliança com seus supostos aliados (os operários, os grupos profissionais e técnicos, os intelectuais e a burocracia estatal); desejavam, verdadeiramente, ampliar seu poder econômico de maneira segura, isto é, sem os “riscos” inerentes ao populismo, mesmo que isso se desse por meio da associação com capitais estrangeiros, e mesmo que isso significasse abrir mão das possibilidades de obtenção da hegemonia política plena da sociedade. O estudo empírico de Cardoso revelava que a burguesia de um país periférico como o Brasil era refratária tanto à idéia de assumir-se como classe politicamente dominante (o que implicaria confrontar os tradicionais setores rurais) quanto, até mesmo, à possibilidade de desenvolver-se autonomamente, por meio de capitais próprios ou nacionais (o que significaria abrir mão da possibilidade de expansão por meio da fusão ou incorporação por empresas e capitais estrangeiros).

É importante ressaltar que a conclusão central do estudo de Cardoso, isto é, de que a os dirigentes industriais do país visavam antes se aliar ao imperialismo do que a ele se opor, nada tinha de trivial ou evidente, como alguns anos depois - em parte, graças próprio estudo em questão - viria a tornar-se. Por certo, já àquela época havia vozes dissonantes - Caio Prado Jr. à frente - quanto à idéia de uma burguesia de orientação nacionalista e progressista, porém o estudo de Fernando Henrique Cardoso seria, salvo engano, o primeiro a basear-se numa pesquisa empírica, apontando os limites do projeto nacional-burguês pelo que os próprios representantes do alto empresariado pensavam sobre o assunto. Até então, os fundamentos do supracitado projeto radicavam mais ou menos inconteste. Do ponto de vista da fundamentação econômica, autores como Celso Furtado sustentavam que a industrialização geraria crescimento econômico e autodinamismo, características centrais das economias desenvolvidas: "Esse autodinamismo é específico da indústria, sendo a razão que faz o setor industrial funcionar como força propulsora do crescimento das economias 
avançadas, que são sistemas autônomos"116; ou em outros termos: "Os centros de decisão que se apóiam nas industrias ligadas ao mercado interno gozam, por definição, de elevado grau de autonomia. Preocupa-os, acima de tudo, a manutenção do nível de emprego e a ampliação de seu mercado"117. Do ângulo da amarração política para esse projeto, destacavam-se as formulações de autores como Hélio Jaguaribe, que vislumbravam na aliança entre a burguesia industrial e o operariado urbano a forçamotriz capaz de contrapor-se aos interesses dos grupos ligados ao imperialismo e ao atraso (a oligarquia rural, a burguesia comercial e a classe média tradicional) e, desta forma, promover um desenvolvimento econômico fundamentado em bases nacionais ${ }^{118}$.

Para Fernando Henrique Cardoso, essas interpretações eram inconsistentes porque não levavam em consideração, ou davam como pressuposto, o elemento central do processo de desenvolvimento, isto é, a dinâmica concreta da relação entre as classes. Assim, por caminhos diversos, as análises de Furtado e de Jaguaribe teriam conduzido a uma mesma insuficiência, vale dizer, a abstração ou o equívoco sobre os condicionantes sociais reais do desenvolvimento. O primeiro, ao caracterizar o desenvolvimento econômico como conseqüência da formação de um mercado interno e da consolidação de um setor industrial de bens de produção, deixava escapar o essencial:, os interesses, objetivos e decisões dos grupos econômicos e sociais, e suas articulações na esfera da arena política, sem o que a interpretação do processo de desenvolvimento tornava-se oca e ambígua, porque “[...] ora supõe o “desenvolvimento” como conseqüência de um jogo de cabra-cega de fatores econômicos incontrolados, ora a "mão invisível do mercado” é substituída pelas artimanhas mais perceptíveis do Estado”"119. Ao não dar a devida importância aos caracteres políticos e sociais do processo de desenvolvimento econômico, argumenta Fernando Henrique, Furtado foi levado a um duplo engano: primeiro ao considerar que a industrialização geraria, por definição, um desenvolvimento autônomo, quando este dependia menos da disposição dos fatores de produção, do que da orientação dos grupos econômicos e sociais que direcionavam todo o processo (o que pressupunha entender o papel das ideologias, como se formavam e se rompiam as alianças políticas, os conflitos econômico-sociais dentro do país e as

116 FURTADO, Celso. Perspectivas da Economia Brasileira. Rio de Janeiro: ISEB, 1958 apud CARDOSO, Fernando Henrique, op. cit, p. 81

${ }^{117}$ FURTADO, Celso. Desenvolvimento e Subdesenvolvimento, op. cit., apud CARDOSO, Fernando Henrique, op. cit, p. 84, grifo nosso.

${ }^{118}$ Cf. JAGUARIBE, Hélio. Desenvolvimento Econômico e Desenvolvimento Político. Rio de Janeiro: Fundo de Cultura, 1962.

${ }^{119}$ CARDOSO, Fernando Henrique, op. cit., p. 85, grifo do autor. 
articulações fora dele etc.); em segundo lugar, e como conseqüência de "retirar da história o nervo político”, considerar que haveria apenas um tipo de civilização industrial, quando "a prevalência da influência de uns ou de outros grupos resultará como é evidente, em tipos diversos de sociedade industriais, nas quais o próprio mecanismo econômico - para não falar no sistema político e nos critérios de estratificação social - será redigido por padrões diferentes”120.

Já nas análises de Hélio Jaguaribe, e do ISEB de maneira geral, embora aqueles caracteres fossem contemplados, chegava-se num resultado igualmente insatisfatório, isso porque o protagonismo histórico atribuído à “burguesia nacional” não correspondia ao pensamento, práticas econômicas ou objetivos políticos desse grupo social. Na verdade, como salientamos anteriormente, os achados da pesquisa de Fernando Henrique apontavam para a direção oposta do que sustentavam os pensadores isebianos e nacional-desenvolvimentistas: os empresários não visavam liderar a sociedade rumo a uma revolução democrático-burguesa de caráter nacionalista, mas sim assegurar seus objetivos econômicos mais prementes, que de forma alguma eram antagônicos aos das forças sociais ligadas ao imperialismo, isto é, as corporações multinacionais e os setores rurais-oligárquicos, ao contrário, havia uma solidariedade de interesses entre eles: os primeiros, no movimento de expansão do capitalismo central, ofereciam a possibilidade de crescimento econômico por meio da associação ${ }^{121}$, e os últimos apresentavam-se como um aliado em potencial contra o populismo, o dirigismo estatal, as temerárias "reformas de base” etc., fatores que, em graus variados, afligiam quase a totalidade dos empresários entrevistados. Nas palavras de Cardoso: “ [...] dos não sei quantos empresários que entrevistei na minha pesquisa, só havia dois que podiam dar verossimilhança a essa idéia [de aliança da burguesia industrial com os trabalhadores, contra o imperialismo]: o José Ermírio de Moraes e o Fernando Gasparian. Todos os demais já estavam se associando às empresas estrangeiras e não apoiavam a reforma agrária”"122. Em resumo, a "burguesia nacional”, tal qual caracterizada por inúmeros intelectuais de esquerda do período, não passava de uma construção idealizada; fruto da

\footnotetext{
${ }^{120}$ Idem, Ibidem, p. 85.

121 Poder-se-ia alegar, em defesa daqueles que viam no imperialismo uma força contrária à industrialização nacional, que, até aquele momento, os “donos do poder” mundial haviam, de fato, se colocado contra as tentativas dos países subdesenvolvidos se industrializarem.Isso não invalida, todavia, a explicação de Cardoso, ao contrário, sua força está justamente em apontar para uma dinâmica que, apesar de incipiente, se tornaria a alavanca do tipo de desenvolvimento econômico engendrado no país nos anos subseqüentes.

${ }^{122}$ Entrevista de Fernando Henrique Cardoso na ocasião dos 40 anos do Cebrap. In: MONTERO, Paula; MOURA, Flávio (Orgs.). op. cit, p.27.
} 
abstração dos reais fatores históricos e estruturais que, numa sociedade periférica como a brasileira, obstaculizavam a formação de elites nacionalmente orientadas.

Pois bem, e que fatores eram esses? Fernando Henrique aponta para dois conjuntos de fatores que condicionavam de maneira decisiva a atuação dos empresários nacionais. Em primeiro lugar, havia a própria debilidade social do empresariado industrial brasileiro: uma camada social heterogênea (em que a influência de seu segmento de origem “agrária” não era nada desprezível), com poucos laços societários que vinculassem uns empresários aos outros, com uma visão muito acanhada a respeito das entidades patronais e da própria participação política, sem muita experiência histórica de classe ("duas gerações de industriais constituem a média entre os "industriais de tradição"123), e cujo impulso para o crescimento, especialmente a partir dos anos 1950, se dava muito mais por fatores exógenos - incentivos estatais e capital estrangeiro - do que endógenos, o que retirava do horizonte empresarial a possibilidade de expansão produtiva por meio dos próprios capitais. Nesse sentido, e aqui a interpretação de Fernando Henrique era muito similar à de Celso Furtado em Desenvolvimento e Subdesenvolvimento:

Não se pode esperar [...] que o empreendedor repita, simplesmente, a história dos homens que fizeram o desenvolvimento do capitalismo no período clássico. Com efeito, o crescimento industrial das áreas subdesenvolvidas realiza-se numa época em que não só as condições do mercado internacional são diversas e balizadas pela ação dos monopólios e grandes companhias, como o padrão técnico da produção é imposto pela ciência e pela prática industrial das economias já desenvolvidas. As condições sociais e econômicas são, pois, diversas. ${ }^{124}$

Assim, numa primeira análise, a fraqueza ou miopia políticas dos industriais deitava raízes em sua própria formação histórica, que por sua vez, derivava em grande medida da divisão internacional do trabalho, a qual, além de ter condicionado a estrutura econômica a partir da qual se processava o desenvolvimento industrial periférico, influía também sobre as condições de concorrência no mercado doméstico e internacional, impactando desta maneira, sobre as perspectivas de realização de lucros dos empresários industriais brasileiros. Por outro lado, à diferença de Celso Furtado, que não via nesse descompasso da formação capitalista nacional um empecilho para a

\footnotetext{
${ }^{123}$ CARDOSO, Fernando Henrique, op. cit, p. 170.

${ }^{124}$ Idem, Ibidem, p. 46.
} 
“transferência dos centros de decisão” para dentro do país, para Cardoso, esse atraso limitava estruturalmente a possibilidade de formação de uma classe burguesa de vocação autônoma e de atitudes quase que abnegadas em prol da sociedade. Ao contrário, as condições acima mencionadas faziam com que os empresários do país tendessem mais a reagir como "massa de manobra”, a acomodarem-se diante da dominação tradicional, do que a agirem politicamente de forma pró-ativa e socialmente criadora, interessada nos assuntos do governo e cimentando as bases que iriam edificar a Nação. A falta de coesão social e de interesses comuns levava esses empresários a agir no plano político, no mais das vezes, de maneira puramente egoística, vale dizer, pautado pelas vantagens ou benefícios econômicos que poderiam auferir para si ou para suas empresas.

O segundo fator apontado por Cardoso condicionando a situação da burguesia brasileira - e naquele contexto, decisivo para os desfechos políticos que se seguiriam era um elemento até certo ponto inédito na história do Brasil contemporâneo, qual seja, a emergência da "sociedade de massas". Fator novo e dinâmico na estrutura social brasileira a partir dos anos 1950, o aparecimento de um amplo setor urbano-popular, e correlativamente, a crescente “participação do povo” no tabuleiro político nacional (ainda que fosse mais uma participação de jure do que de facto) teria, segundo Fernando Henrique, conseqüências ambíguas para os empresários. Por um lado, os sindicatos, os grupos nacionalistas, os partidos e entidades “populares” etc., em sua pressão social e reivindicações trabalhistas contribuíam para a melhoria das condições do próprio crescimento industrial, seja através do alargamento do mercado consumidor (conseqüência direta da luta por melhores salários), seja por meio dos subsídios e incentivos dados à indústria nacional (resultado “indireto" da luta daqueles grupos contra as corporações estrangeiras). Por outro lado, esses mesmos agentes representavam no imaginário social dos empresários uma ameaça em potencial, seja porque, em suas lutas trabalhistas, colocavam em risco boa parcela de seus lucros, seja porque ameaçavam romper a qualquer instante a ordem institucional vigente - a temida e malfada revolução socialista. Por isso, os empresários ficavam divididos entre duas posições antagônicas: apoiar as massas populares na construção do Brasil novo, urbano e industrializado, e correr o risco de verem-se arrastados num movimento insurrecional ou sujeitarem-se à dominação tradicional e ao imperialismo, garantindo sem maiores sobressaltos sua expansão econômica, porém abdicando da possibilidade de obtenção da 
hegemonia política da sociedade. Se bem que a ambigüidade política do empresariado havia sido possível até aquele momento, Cardoso vaticina que essa hesitação estava com seus dias contados. A deterioração do quadro político-institucional (e o autor está escrevendo num dos momentos mais críticos antes do golpe militar, no período após a renúncia de Jânio Quadros, quando se instaurou o regime parlamentarista no país) e o agravamento das tensões sociais na cidade e no campo colocariam os empresários numa encruzilhada, obrigando-os a optar definitivamente por uma das opções. Guardadas as devidas proporções e diferenças históricas, estavam diante do velho dilema: "fim com terror ou terror sem fim”? A dura e profética - porém certeira - conclusão de Fernando Henrique, escrita cerca de um ano antes do golpe militar, não deixava dúvidas de qual seria essa escolha:

As possibilidades de manutenção deste malabarismo são contudo limitadas. Estreita-se a cada dia a faixa de compromissos possíveis. As decisões fundamentais não dependerão apenas da burguesia industrial que, parece, optou pela “ordem”, isto é, por abdicar de uma vez por todas de tentar a hegemonia plena da sociedade, satisfeita já com a condição de sócio-menor do capitalismo ocidental e de guarda avançada da agricultura que muito lentamente se capitaliza. Resta verificar qual será a reação das massas urbanas e dos grupos populares e qual será a capacidade de organização e decisão de que serão capazes para levar mais adiante a modernização política e o processo de desenvolvimento econômico do país. No limite a pergunta será então: subcapitalismo ou socialismo. ${ }^{125}$

Como se sabe, pouco após a publicação do livro, os acontecimentos políticos do país mostrariam o acerto da previsão do autor. Apoiado pelo grosso da elite empresarial brasileira, o golpe de militar de abril de 1964 lograria “restabelecer a ordem” e garantir um ambiente de negócios estável e favorável à acumulação capitalista dos industriais. Com o auxílio do capital estrangeiro e das corporações multinacionais, os militares acelerariam e completariam a criação de um robusto setor de bens-de-capital, assim como um setor de bens-de-produção duráveis, espalhando automóveis e geladeiras pelas ruas e casas brasileiras. Entretanto, a vigorosa modernização da economia brasileira proporcionada pelos militares só seria possível graças, em parte, ao aumento exponencial das desigualdades sociais, ao aprofundamento da subordinação externa do país, ao agravamento das condições de vida nos grandes centros urbanos, e por fim, ao cerceamento das liberdades civis e políticas. Poder-se-ia ainda falar, deste ângulo, que

${ }^{125}$ CARDOSO, Fernando Henrique. O empresário industrial e desenvolvimento econômico no Brasil. $2^{\mathrm{a}}$. ed. São Paulo: Difusão Européia do Livro, 1972, p. 197-198. 
estava em curso no país um processo de desenvolvimento? Escrevendo ainda às vésperas de todas essas transformações que ocorreriam na economia, política e sociedade brasileiras, e já antevendo algumas delas, Cardoso parecia responder afirmativamente à pergunta. Tratava-se com efeito de um processo de desenvolvimento capitalista, entendo-se isso como o crescimento da atividade econômica, a modernização e diversificação das estruturas produtivas, e até uma moderada diferenciação na estrutura social, no entanto, haveria de ser um desenvolvimento condizente com as condições históricas particulares - periféricas - da sociedade brasileira: heterônomo, socialmente excludente e politicamente fechado, ou, conforme a expressão utilizada pelo autor àquele momento, do tipo “sub-capitalista”.

Vê-se, pois, que o diagnóstico trazido pelo autor ao final de Empresário Industrial já está à meio-caminho de uma teoria da dependência sobre o desenvolvimento capitalista em regiões periféricas do planeta. Entretanto, a caracterização de Cardoso ainda estava restrita ao caso brasileiro ${ }^{126}$. Além disso, várias indagações poderiam ser feitas a partir da leitura do livro: como as condições que pareciam tão favoráveis nos anos 1950 não levaram à concretização dos sonhos e esperanças desenvolvimentistas de uma sociedade autônoma e mais justa?; como ficava nesse quadro “o projeto de Nação”, idéia presente desde tempos imemoriais na América Latina?; estariam esses países fadados a perpetuar o subdesenvolvimento (ainda que um subdesenvolvimento com modernização econômica)?; se não, que forças políticas ou grupos sociais teriam a motivação e capacidade de levar a cabo um projeto alternativo de desenvolvimento? Essas e outras perguntas seriam enfrentadas por Fernando Henrique em seus próximos estudos, denotando assim sua entrada definitiva no debate sobre a dependência.

Com efeito, seu próximo livro, que reunia uma série de artigos escritos entre 1964 e 1967, intitulado Mudanças Sociais na América Latina, pode ser considerado a primeira incursão explícita de Cardoso acerca do tema, e o primeiro em que o autor faz alusão ao termo "teoria da dependência”. Embora o livro tenha tido pouco repercussão no país - sobretudo se comparado com o sucesso editorial de Dependência $e$ Desenvolvimento, publicado pela primeira vez no Brasil apenas um ano após Mudanças

${ }^{126}$ Em trabalho posterior, Cardoso realizaria um estudo sociológico semelhante, e chegaria a conclusões igualmente semelhantes, em relação ao empresariado industrial argentino. Veja-se CARDOSO, Fernando Henrique. Política e Desenvolvimento em Sociedades Dependentes - Ideologias do Empresariado Industrial Argentino e Brasileiro. $2^{\mathrm{a}}$. ed. Rio de Janeiro: Zahar Editores, 1978 
Sociais - nele encontram-se já assinaladas muitas das definições básicas para o autor a respeito do conceito de dependência e também sobre os procedimentos teóricometodológicos necessários a fim de se caracterizar as distintas situações históricoestruturais do desenvolvimento latino-americano. Vejamos então como o autor procede.

Uma das primeiras tarefas enfrentadas por Cardoso no livro será a de defender a necessidade de um novo paradigma teórico sobre o estudo do desenvolvimento latinoamericano. Para tanto, o autor vai argumentar no sentido de evidenciar as limitações de ordem tanto teóricas quanto práticas dos modelos de interpretação vigentes:

À medida em que o processo de desenvolvimento, por um lado, se realizava através de mecanismos sociais que não eram "esperados", quer dizer que não repetiam os processos já ocorridos nos países desenvolvidos e, por outro lado, levava a conseqüências também não antecipadas nem pelas teorias nem pelas ideologias do desenvolvimento (por exemplo, a consolidação de regimes autoritários ao invés da ampliação da democracia representativa, o entrelaçamento dos interesses econômico-financeiros das burguesias locais com os monopólios internacionais, a reconversão parcial dos setores agráriotradicionais às economias de base técnico-capitalista etc.) tornavam-se manifestas as insuficiências das teorias do desenvolvimento como base de previsão social. ${ }^{127}$

Em suma, o desenvolvimento do Brasil e dos países vizinhos transcorria contrariando, em quase sua totalidade, o prognóstico civilizatório anteriormente traçado: ampliando os vínculos de dependência externa, ao invés de esgarçá-los ou rompê-los; preservando os interesses econômicos dos tradicionais grupos "ligados ao subdesenvolvimento”, em vez de expurgá-los; e de maneira a reduzir as liberdades políticas e civis, ao invés de propiciar a ampliação da participação popular. Para o autor, essa disjunção das teorias desenvolvimentistas em relação ao processo histórico-social da América Latina se devia devido ao fato de elas terem adotado como modelo, e terem derivado daí seu arcabouço analítico-normativo, o “padrão clássico” (e, diga-se de passagem, igualmente idealizado) de desenvolvimento, leia-se da Europa Ocidental e dos EUA. Não por acaso, nesse tipo de abordagem os agentes sociais da mudança (a burguesia, o proletariado etc.) se pareciam mais com personagens saídos de livros de História desses países do que da realidade concreta latino-americana. Para Cardoso, padeciam dessa insuficiência analítica tanto as interpretações marxistas, que

${ }^{127}$ CARDOSO, Fernando Henrique. Mudanças Sociais na América Latina. São Paulo: Difusão Européia do Livro, 1969, p. 14. 
instrumentalizavam as funções sociais cumpridas pelas diferentes classes na formação clássica do capitalismo em uma ideologia do desenvolvimento nacional, quanto aquelas de inspiração liberal, que buscavam "vestir com trajes civilizados" um contexto histórico aparentemente caótico ${ }^{128}$. Num caso como noutro, a análise do real baseava-se numa visão formalista e a-histórica dos processos sociais, sendo pouco útil, portanto, tanto como teoria social quanto como base de previsão de transformações socioeconômicas.

A percepção de que a modernização econômica da América Latina não implicaria em uma radical transformação de suas arcaicas relações-de-produção, nem tampouco provocaria uma guinada rumo a uma maior autonomia de decisões no âmbito do circuito capitalista internacional, colocava abaixo o economicismo das interpretações desenvolvimentistas e, simultaneamente, lançava luzes sobre um aspecto apenas marginalmente contemplado naquelas explicações, isto é, a esfera da política: “[...] desenvolvimento e independência nacional não provaram ser dimensões correlatas. Deste modo, já não se podia mais considerar as formas de organização política - modos de controle que as relações entre os grupos sociais assumem no processo de desenvolvimento - como meros resultados casualmente subordinados às transformações econômicas, como implicitamente propunham as teorias econômicas do desenvolvimento"129. A análise histórica do processo de desenvolvimento exigia, pois, foro privilegiado ao problema do poder e à maneira pela qual a heteronomia nacional, país a país, se constituía e se perpetuava. Eis o substrato teórico do modelo de interpretação que se pretendia constituir: "Esta revalorização da dimensão política na história dos povos dependentes e a redescoberta do caráter fundamental da situação de dependência na formação destes países, constituem, sem dúvida, o contexto dos novos desafios intelectuais postos pela situação latino-americana”130.

Entretanto, argumenta Fernando Henrique, o simples reconhecimento da situação de dependência, como um fenômeno ao mesmo tempo histórico e estrutural, político e econômico, não constituía, por si só, um novo saber científico ou uma nova maneira de se explorar os problemas sociais enfrentados pelos países da região. Para que o reconhecimento político das relações assimétricas entre uma periferia

\footnotetext{
${ }^{128}$ Idem, Ibidem, p. 8

${ }^{129}$ Idem, Ibidem, p. 15, grifo do autor

${ }^{130}$ Idem, Ibidem, p. 16, grifo do autor.
} 
subdesenvolvida e um centro hegemônico representasse um elemento heurístico importante na análise e um ganho científico para as ciências sociais latino-americanas, seria necessário caracterizá-las mais do que apenas mecanicamente condicionadas pela expansão do sistema capitalista internacional (o que, de certa maneira, era o modo como as teorias do imperialismo lidavam com o fenômeno). Era necessário admitir que a dominação externa se materializava a partir de condicionantes inscritos nas próprias sociedades dependentes, e que, sem entender a estrutura e dinâmica destes, em sua “autonomia relativa” e em sua sua articulação com os determinantes mais gerais do capitalismo e do imperialismo, seria impossível explicar o processo de desenvolvimento em curso nos países da região. Como se vê, é basicamente o modelo de Capitalismo e Escravidão no Brasil Meridional sendo reaplicado agora para se entender o fenômeno contemporâneo da dependência econômica da região:

[...] a análise das formas específicas da dependência não pode limitar-se à caracterização de uma estrutura reflexa com relação a outra; requer a análise de ambas em sua interrelação. Exatamente daí retira sua força o conceito de dependência: a rigor, as estruturas dependentes não podem ser concebidas como meramente reflexas; ao contrário, têm uma dinâmica própria dentro dos limites definidos pelas relações de dominação-subordinação entre países. Essas anotações nos conduzem a uma observação importante do ponto de vista da análise: dado que as estruturas dependentes possuem uma autonomia relativa, torna-se possível tratar de entender de seu próprio ângulo as modificações que aí se verificam. ${ }^{131}$

Em outras palavras, era no interior das próprias nações em desenvolvimento, na mediação de suas estruturas internas de dominação, que se deviam buscar as condições sociais e políticas que as mantinham vinculadas de forma subordinada aos centros hegemônicos das economias capitalistas centrais. E nisso residia o grande desafio intelectual da compreensão e caracterização da situação latino-americana, pois embora esta fosse histórica e estruturalmente condicionada pelo domínio político-econômico externo (colonialismo, imperialismo etc.), era apenas por meio dos grupos e forças sociais que, no interior das regiões periféricas, se estabeleciam e perpetuavam os vínculos externos de dependência (“[...] a estrutura externa passa a ser vivida como interna”, ${ }^{132}$ ). Nessa emaranhada equação entre determinantes externos e internos, o externo fornecia a medida do possível, os limites estruturais, mas a dinâmica do real, o

\footnotetext{
${ }^{131}$ Idem, Ibidem, p. 17.

${ }^{132}$ Idem, Ibidem, p. 17
} 
concreto, era mediado pelo interno, em sua relativa autonomia em relação ao externo. E é precisamente por causa dessa autonomia relativa de cada país ou região (ou melhor, das classes sociais que atuam no interior dessas localidades) que se deviam conceber distintas situações de dependência, e não uma única e abstrata situação, como se fosse conseqüência de uma relação, igualmente abstrata, de subordinação. De uma maneira geral, todas as nações periféricas sofriam o "peso" das estruturas externas de dominação, mas a maneira como isso se dava, o grau de interpenetração nos sistemas produtivos nacionais, a forma política assumida, e até, a eventual possibilidade de superação dos vínculos de dependência, tudo isso dependia do jogo de forças dos grupos atuando no interior do sistema econômico e social de cada nação periférica.

E quais eram então, para Cardoso, essas distintas situações de dependência, e como sua própria explicação logrou evitar descrevê-las como conseqüências mecânicas de um condicionamento geral e externo, e nem tampouco - o que não era, senão, um equívoco de natureza diametralmente oposta - como estruturas sociais e econômicas “irredutivelmente singulares”? Em Mudanças Sociais, Cardoso apenas dá pistas dessa sistematização. Seria apenas em seu próximo livro, escrito em parceria com o sociólogo chileno Enzo Faletto, que uma análise e uma descrição detalhadas das diferentes formas historicamente assumidas pelo capitalismo dependente na região seria empreendida.

Como afirmamos anteriormente, Cardoso e Faletto realizam em Dependência e Desenvolvimento uma análise histórica e sociológica do processo de desenvolvimento de vários países da região, com foco especial para Brasil, Argentina, Chile e México, mas trazendo também os exemplos do Uruguai, Colômbia, Venezuela, Peru entre outros. Ainda que a descrição do processo histórico destes últimos países seja bastante sucinta, e em alguns casos patentemente insuficiente, a obra tem o mérito - e provavelmente vem daí sua originalidade e grande repercussão - de conceber diversas situações de dependência e subdesenvolvimento, num momento em que a maioria das análises sobre a dependência tendiam a voltar-se para os mecanismos ou leis gerais e do desenvolvimento-dependente que afligiriam indistintamente todos os países da região. Nesse sentido, o esforço dos autores em realizar uma análise concreta das situações de dependência, caracterizando as modificações na economia, na política e na sociedade, em função dos condicionantes externos e internos de cada país ou grupo de países, não deixou de representar um avanço metodológico no estudo do capitalismo periférico. 
Pois bem, metodologicamente o fenômeno da dependência na América Latina tem início para os autores logo ao fim do pacto colonial. Isso porque, argumentam eles, antes disso, a dinâmica histórica das colônias ibero-americanas era meramente reflexiva às imposições de suas respectivas metrópoles. Nesse sentido, não haveria necessariamente uma problemática sociológica no estudo do desenvolvimento ou formação capitalista dessas regiões. Esta problemática surgiria propriamente quando, logo após ter se iniciado o processo de independência política latino-americana, permaneceram, diferenciaram-se e, em alguns casos, ampliaram-se as relações de dependência ou subordinação econômica externa.

Com efeito, se nas situações de dependência colonial é possível afirmar com propriedade que a história - e, por conseguinte, a mudança - aparece como reflexo do que se passa na metrópole, nas situações de dependência das "nações subdesenvolvidas” a dinâmica social é mais complexa. Neste último caso há desde o começo uma dupla vinculação do processo histórico que cria uma "situação de ambigüidade", ou seja, uma nova contradição. Desde o momento em que se coloca como objetivo instaurar uma nação - como no caso das lutas anticolonialistas -, o centro político da ação das forças sociais tenta ganhar certa autonomia ao sobrepor-se às situações do mercado; as vinculações econômicas, entretanto, continuam sendo definidas objetivamente em função do mercado externo e limitam as possibilidades de decisão e ação autônomas. Nisso radica, talvez, o núcleo da problemática sociológica do processo nacional de desenvolvimento da América Latina ${ }^{133}$.

Portanto, a dependência para os autores era um fenômeno essencialmente moderno, surgido da ambivalência de nações que, tendo adquirido a soberania política formal, continuavam, objetivamente, em posição subordinada nas relações econômicas internacionais. Dessa situação derivavam os constrangimentos estruturais que travejavam seu desenvolvimento histórico, comparativamente ao desenvolvimento das economias centrais, e que lhe imprimiam aquele caráter econômico-social singular, de economias dependentes. Na periodização histórica da dependência na América Latina, Cardoso e Faletto concebem três situações histórico-estruturais distintas ${ }^{134}$.

\footnotetext{
${ }^{133}$ CARDOSO, Fernando Henrique; FALETTO, Enzo, op. cit., p.44

${ }^{134} \mathrm{~A}$ sistematização aqui realizada é ligeiramente diferente da contida em Dependência $e$ Desenvolvimento. Enquanto naquele os autores realizam uma descrição diacrônica das transformações ocorridas, aqui, para efeitos de simplificação e exposição, preocupamo-nos mais com seus caracteres sincrônicos, enfatizando as diferentes situações de dependência.
} 
Na primeira dessas situações, que diz respeito basicamente aos exemplos históricos da Argentina e do Brasil ${ }^{135}$, a força e articulação dos setores que constituíam o núcleo econômico do sistema colonial (plantadores, mineradores e banqueiros) propiciou que, logo após o término desse sistema, se organizasse um controle nacional do sistema produtivo. A fim de consolidar a formação do Estado Nacional, organizar as bases do sistema produtivo local, e não menos importante, estabelecer uma "ordem legítima” de dominação, as forças sociais que “forjaram a independência” lograram estabelecer um duplo pacto de alianças: no plano interno e externo. Internamente, buscaram se associar (no caso argentino, mais na base da imposição do que numa política de acordos) a grupos proprietários relativamente marginais ao sistema exportador (como as oligarquias regionais no Brasil), que eram, todavia, indispensáveis para a manutenção da ordem social e da estabilidade política. Externamente, procuraram reorientar os laços de dependência em direção aos novos pólos hegemônicos, num primeiro momento a Inglaterra, e posteriormente os Estados Unidos. Se bem que essas sociedades não tenham deixado de sofrer as conseqüências de possuir uma estrutura econômico-social dependente, como por exemplo, a deterioração dos termos de intercâmbio, elas não deixaram de preservar parte de sua autonomia e conseguiram, até certo ponto, acumular capitais dentro do próprio território.

O êxito do modelo agrário-exportador, prosseguem os autores, ao propiciar a diferenciação interna do sistema produtivo (com maior intensidade no Brasil do que na Argentina), provocou simultaneamente o surgimento ou o fortalecimento de grupos não diretamente ligados à economia exportadora e, portanto, contrários à dominação oligárquica, como a burguesia industrial, o operariado e os chamados "setores médiourbanos”. À reação desses grupos, somou-se, no caso brasileiro, o descontentamento de oligarquias insatisfeitas com a reduzida parcela de poder que lhes era outorgada pelo núcleo político dominante, isto é, os agricultores mineiros e paulistas. Com a crise do modelo de dominação oligárquica instaurada, amplificada pela crise de 29, e sua substituição por um novo sistema de alianças, ancorado especialmente nessas forças sociais emergentes, têm-se inicio uma nova etapa de desenvolvimento nesses países, denominada de consolidação do mercado interno, ou de “desenvolvimento para dentro”. A partir desse momento, há um fortalecimento do papel do Estado e uma deliberada

\footnotetext{
${ }^{135}$ Enquadram-se também nessa situação, embora os autores dêem menos destaque, os casos do Uruguai e da Colômbia.
} 
política no sentido de favorecer o incipiente processo de industrialização, ainda que sem ferir os interesses dos antigos grupos hegemônicos, uma vez que era por meio das rendas obtidas pelas exportações primárias que se financiava a industrialização por substituição de importações. Os autores pontuam, contudo, uma diferença fundamental entre as transformações ocorridas na Argentina e Brasil: enquanto que no primeiro país a existência de um setor empresarial forte e hegemônico, vale dizer, a burguesia buenairense, fez com que a industrialização fosse do tipo liberal, isto é, conduzida diretamente pelos próprios representantes da classe burguesa, sem tanta mediação estatal $^{136}$, no Brasil, a inexistência de um grupo social equivalente fez com que a industrialização fosse do tipo nacional-populista, isto é, “orientada por uma vontade política que expressa a pujança de forças sociais, como a burguesia, os setores médios e os populares (sindicatos), vinculados ao sistema de poder (ao Estado), os quais, junto com o setor agroexportador-importador - e ainda em disputa com ele - compartem, em grau diverso, a condução do processo de desenvolvimento"137. Sem embargo, tanto no Brasil (varguismo) quanto na Argentina (peronismo), o populismo foi a forma política preferencial assumida pela nova “conjuntura de poder”.

No segundo tipo de situação descrita pelos autores, a fraqueza política e a debilidade econômica dos grupos sociais locais impediu que, findado o pacto colonial, esses grupos mantivessem o controle ou predomínio do sistema produtivo nacional. Nessas regiões, que incluíam, entre outros, o México, o Chile, a Venezuela e o Peru, o núcleo do sistema econômico ficou sob controle de empresas ou capitais estrangeiros, constituindo o que Cardoso e Faletto denominaram de economias de enclave. Os grupos dominantes locais exerceram, nesses países, um papel apenas secundário na dinamização econômica, uma vez que “[...] tanto o controle das decisões de investimento depende diretamente do exterior como os lucros gerados pelo capital apenas "passam” em seu fluxo de circulação pela nação dependente, indo incrementar a massa de capital disponível para investimentos na economia central” ${ }^{\text {"38 }}$. A formação de um mercado interno nesses casos foi muito deficiente e incapaz de suscitar a formação de blocos de poder que tomassem as rédeas do processo de desenvolvimento durante

\footnotetext{
136 “[...] nesse modelo de desenvolvimento as diferenças foras sociais não pressionavam suficientemente para que o Estado se transformasse de um instrumento de regulação econômica em outro de ação produtiva direta: a base econômica anterior permitia aos setores privados levar adiante a diferenciação econômica interna, sem que se tornasse indispensável a formação de um setor público no sistema produtivo". Idem, Ibidem, p.132

${ }^{137}$ Idem, Ibidem, p.127

${ }^{138}$ Idem, Ibidem, p.69
} 
todo o período de "expansão para fora”. É por isso que no período seguinte, na fase de “desenvolvimento para dentro”, o Estado vai ter, nesse tipo de formação estrutural, um papel muito mais relevante que nos casos brasileiro e argentino, preenchendo a ausência de um importante setor capitalista exportador-importador com um forte programa estatal de investimentos e incentivos à industrialização (“Estado desenvolvimentista”).

E por fim, Cardoso e Faletto concebem um terceiro tipo de situação históricoestrutural na América Latina, denominada de “internacionalização do mercado interno”, que correspondia à nova etapa de desenvolvimento capitalista de algumas das economias mais avançadas da região àquela época, notadamente, o Brasil, a Argentina e o México. Para os autores, essa etapa tivera uma dupla origem: o término ou esgotamento do processo de substituição “fácil” de importações e a crise do sistema nacional-populista de dominação.

Segundo os autores, os fatores que haviam permitido o funcionamento relativamente bem-sucedido do modelo de “desenvolvimento para dentro" começaram a desaparecer ainda na década de 1950. E um dos principais, senão o principal fator citado fora a queda dos preços dos principais produtos de exportação da região, ocorrida a partir de meados daquele decênio. Base de financiamento da política substitutiva de importações e das medidas de cunho populistas adotada pelos governos locais, a queda da renda obtida por meio das vendas do "setor externo" da economia abalou profundamente os fundamentos da "aliança-desenvolvimentista”, que pressupunha algum nível - ainda que restrito - de redistribuição dos ganhos às massas, e deixou transparecer os limites estruturais para um desenvolvimento industrial controlado nacionalmente, em especial, o reduzido volume de formação e acumulação de capitais necessário à constituição da moderna economia industrial:

É certo que o início de um processo moderno de industrialização nas nações periféricas supõe consideradas remessas de capital e uma numerosa soma de conhecimentos tecnológicos e graus avançados de organização empresarial, os quais implicam desenvolvimento científico, complexidade crescente e diferenciação da estrutura social, acumulação e investimento prévios. A disponibilidade dessas condições por parte das nações centrais leva a um desenvolvimento dos laços de dependência ${ }^{139}$.

\footnotetext{
${ }^{139}$ Idem, Ibidem, p.165.
} 
Cabe ressaltar que os autores chegam a enumerar uma série de alternativas à internacionalização da economia, vale dizer, à abertura do mercado interno às grandes corporações transnacionais, como a contenção da política salarial, o enfrentamento com o setor agroexportador, a exclusão do setor urbano-popular do processo econômico, entre outras. Entretanto, argumentam eles, todas essas alternativas estariam fadadas ao fracasso, uma vez que seriam politicamente inviáveis ou economicamente anacrônicas ${ }^{140}$. Assim sendo, dentro dos marcos do modo capitalista de produção, a vinculação econômica dos mercados internos das nações períiféricas ao mercado mundial se mostrava como a solução mais factível frente os limites impostos pelo “desenvolvimento genuinamente nacional”. Mediante o ingresso de capitais, técnicas produtivas, bens de capital e conhecimentos científicos provenientes das economias avançadas, permitir-se-ia dar prosseguimento ao crescimento da atividade econômica, e simultaneamente, constituir as bases de um setor industrial de ponta (eletrônico, químico, automobilístico etc.).

Entretanto, como é evidente, a internacionalização e modernização dessas economias tinha um alto preço a ser pago: o aprofundamento da heteronímia econômico-social e a perda da capacidade dos grupos locais em orientar as decisões de investimentos e as pautas de consumo ${ }^{141}$. Assim, o crescimento do endividamento externo, a dependência tecnológica e cultural, a tendência à utilização de técnicas de produção não condizentes com o nível de desenvolvimento do sistema produtivo local, a “oligopolização” do mercado interno etc., tudo isso estava embutido implícita ou explicitamente no novo esquema de desenvolvimento econômico. E mais ainda, dado que o pólo dinâmico dessa nova situação de dependência radicava nas grandes unidades monopolistas nacionais e internacionais, assim como no setor público-estatal, ou seja, dependia mais do consumo entre as próprias empresas do que da demanda do consumidor final, era perfeitamente possível, e até necessário, como uma maneira de se alavancar a capacidade de acumulação desses setores, limitar a redistribuição dos ganhos econômicos às massas. Dessa maneira, a exclusão social e a marginalidade urbana não apenas eram fenômenos compatíveis com a nova etapa do desenvolvimento latino-americano, como, até certo ponto, eram requisitos para sua implantação e

\footnotetext{
${ }^{140}$ Idem, Ibidem, p.156-157.

141 “[...] os mecanismos de controle da economia nacional escapam parcialmente do âmbito interno na medida em que certas normas universais do funcionamento de um sistema produtivo moderno, impostas pelo mercado universal, não permitem alternativas: a unificação dos sistemas produtivos leva à padronização dos mercados e a seu ordenamento supranacional”. Idem, Ibidem 167.
} 
manutenção. O fato da modernização do sistema produtivo vir acompanhada de arrocho-salarial, concentração de renda, aumento dos níveis de desemprego, etc., não representava para os autores uma obstrução estrutural à continuidade do crescimento econômico (a tão propalada, à época, tendência à estagnação), esta era apenas “a forma que o capitalismo industrial adota no contexto de uma situação de dependência” ${ }^{142}$.

Seguindo a metodologia desenvolvida em todo o livro, Cardoso e Faletto argumentam, no entanto, que a “internacionalização do mercado interno" não era conseqüência única e exclusiva das determinações econômicas. Para que estas se efetivassem concretamente, era mister um arranjo político que, expressando a hegemonia de determinadas classes, grupos ou movimentos sociais no âmbito das nações subdesenvolvidas, permitisse, desse vazão e forma à dominação econômica externa. Em outras palavras, era por meio da análise da política e das relações de poder (ou conforme a denominação comumente empregada, das “estruturas de dominação” ${ }^{143}$ ) que seria possível compreender a nova situação de dependência em sua plenitude:

Seria errôneo pensar que os novos fatores que condicionam o desenvolvimento, a política e a dependência externa circunscrevem-se ao âmbito do processo econômico, pois seria precipitado crer que a determinação econômica do processo político, a partir da formação de um avançado setor capitalista nas economias dependentes, permite a "explicação" imediata da vida política pelos condicionantes econômicos. O conceito de dependência permanece básico para caracterizar a estrutura dessa nova situação de desenvolvimento e, portanto, a política continua sendo o meio pelo qual se possibilita a determinação econômica. ${ }^{144}$

Cardoso e Faletto vão buscar na crise do esquema nacional-burguês de dominação, e no subseqüente realinhamento das principais forças políticas em disputa,

\footnotetext{
${ }^{142}$ Idem, Ibidem, p. 160.

${ }^{143}$ É importante ressaltar que, embora a política ocupasse um lugar privilegiado na análise dos autores, esta não era apreendida da mesma maneira que a maioria dos estudos em voga na ciência política contemporânea, isto é, ao nível da "política institucional”, mas num nível supostamente acima desta, na chamada estrutura de dominação: “[...] o problema teórico fundamental é constituído pela determinação dos modos que adotam as estruturas de dominação, porque é por seu intermédio que se compreende a dinâmica das relações de classe. Ademais, a configuração em um momento determinado dos aspectos político-institucionais não pode ser compreendida senão em função das estruturas de domínio. Em conseqüência, também é por intermédio de sua análise que se pode captar o processo de transformação da ordem político-institucional. Esta opção teórica fica apoiada empiricamente pelo fato de que as transformações históricas significativas do processo de desenvolvimento latino-americano têm sido sempre acompanhadas, senão de uma mudança radical na estrutura de dominação, pelo menos pela adoção de novas formas de relação, e portanto, de conflito, entre as classes e grupos.” Idem, Ibidem, $p$. 34-35, grifo nosso.

${ }^{144}$ Idem, Ibidem, p.149, grifo nosso.
} 
as origens da nova aliança de poder que se afiguraria a partir dos anos 1960 nos principais países da região. Com a obsolescência da antiga aliança desenvolvimentista, isto é, com um pacto de poder que não representava os interesses e objetivos do novo pólo dinâmico da economia (as empresas transnacionais), e nem sequer era capaz de pôr termo aos crescentes conflitos políticos ocorrendo por toda a sociedade, bem como no interior da própria aliança em questão, uma nova "situação de poder" - que, no exemplo histórico brasileiro, seria materializada a partir do golpe militar de 64 - será formada. Sairão então de cena os representantes da "velha indústria” (ligado ao setor de bens-deconsumo leve), do setor de agroexportação, e, marginalmente, do operariado urbano, e em seu lugar entrará em funcionamento uma aliança fundamentada na empresa multinacional e no setor financeiro, ou mais precisamente, nas burguesias internacionalizadas. Ao lado delas, e ainda em disputa com elas, outros dois setores econômicos irão compor o arco de alianças responsável pela sustentação política do novo modelo de desenvolvimento latino-americano, quais sejam, as empresas estatais (e seu congênere social, as tecnoburocraciais civis e militares), e a grande empresa privada nacional, associada a ambos os setores, numa conjuração de forças - nem sempre harmônicas entre si - que posteriormente Cardoso irá denominar de tripé do desenvolvimento dependente-associado ${ }^{145}$. Às camadas prevalecentes no modelo político anterior, notadamente o empresário industrial tradicional (isto é, não-ligado ao setor monopolista), restará - e, na verdade, este será seu grande objetivo - vincular-se de forma subordinada ao sistema de dominação que se instaura ${ }^{146}$.

Mas não é apenas o sistema de alianças que muda. Também o Estado, sustentam Cardoso e Faletto, vai desempenhar nessa situação de dependência novos papéis: ao invés do “Estado-populista”, preocupado com a redistribuição da renda e com um desenvolvimento capitalista predominantemente "nacional”, um "Estado-gerencial”, por suposto, desenvolvimentista, porém neutro quanto à preferência da nacionalidade do capital, e muito mais interessado em garantir a aceleração dos investimentos (seja diretamente por meio das empresas estatais, seja indiretamente por meio da atração do capital externo) e em criar um ambiente econômico favorável à acumulação de capitais na indústria, do que em implementar políticas sociais redistributivas. Daí também porque os autores consideravam que o autoritarismo civil ou militar seria a forma

145 CARDOSO, Fernando Henrique. "Notas sobre o estado atual dos estudos sobre dependência”. Cadernos Cebrap, São Paulo, vol. 11, 1973, p.58.

${ }^{146}$ CARDOSO, Fernando Henrique; FALETTO, Enzo, op. cit., p.169 
política preferencial assumida pelos países dependentes quando estes entrassem num processo de modernização de seus sistemas produtivo ${ }^{147}$ : por meio do enfraquecimento ou mesmo supressão da organização político-partidária, da debilitação da sociedade civil, do esmagamento das reinvindicações populares-trabalhistas etc., eliminar-se-ia as tendências "perturbadoras” do desenvolvimento, facilitando assim a consolidação do regime de acumulação capitalista dependente.

Claro estava, diante da exposição dos autores, que as bases para uma nova etapa de desenvolvimento estavam bem estabelecidas nas economias mais avançadas da região, e que, não obstante a ampliação e redefinição dos laços de dependência, seria de se esperar que essas economias experimentassem um vigoroso processo de modernização de seus sistemas produtivos e até mesmo uma complexificação de suas estruturas sociais (o surgimento ou fortalecimento de um operariado "moderno", de um empresariado ligado ao setor de alta produtividade etc.). Nesse sentido, e o "milagre" brasileiro seria a grande comprovação desta proposição, não haveria motivos para se conceber uma tendência estrutural à estagnação. A mudança na estrutura de dominação, a colaboração com o capital estrangeiro, e até mesmo as novas funções do Estado, haviam superado as barreiras transitórias que haviam se colocado no início dos anos sessenta para o crescimento da atividade econômica. Sem embargo, dado o enorme custo social e humano que estas transformações econômicas traziam em seu bojo, poder-se-ia indagar que alternativas políticas existiriam para os povos subjugados da América Latina. Ou em termos mais amplos, estariam essas sociedades fadadas a repisar continuadamente a forma política e socioeconômica que o desenvolvimento capitalista adquire em regiões periféricas do globo, isto é, dependente e associado, excludente e pouco ou nada democrático (e, em caso negativo, em que classes ou grupos sociais repousariam a força e determinação políticas para alterar esse quadro?). Não há nas páginas que encerram Dependência e Desenvolvimento uma resposta unívoca para essas perguntas. Por certo, Cardoso e Falletto consideravam pouco provável tanto uma restauração das tendências nacional-reformistas, quanto uma revolução socialista. Entretanto, os autores não têm uma resposta pronta à clássica pergunta: “O que fazer?”. Na verdade, eles adotam uma posição explicitamente cautelosa - alguns diriam, evasiva

147 “Tudo leva a crer que a passagem para o estabelecimento de um modo capitalista-industrial de produção relativamente desenvolvido em países dependentes se assente em regimes políticos autoritários (sejam militares ou civis), cujo ciclo de duração dependerá tanto dos êxitos econômicos e do avanço que possam lograr na reconstrução social quanto do caráter, do tipo de ação ou êxito dos movimentos de oposição baseados nos grupos e classes que assinalamos anteriormente”. Idem, ibidem, 177 
- em delinear caminhos alternativos ao desenvolvimento da região, evitando assim “a vã pretensão de tentar delimitar teoricamente o curso provável dos acontecimentos futuros” ${ }^{\text {448 }}$. Se possibilidades existiam para a superação da condição de subdesenvolvimento, argumentavam os autores, estas dependiam "mais que de condições econômicas tomadas isoladamente, do jogo de poder que permitirá a utilização variável dessas “condições econômicas” 149 .

Para as forças políticas de direita no Brasil, sobretudo aquelas vinculadas aos militares, nada havia de fundamentalmente problemático no padrão de desenvolvimento em curso: afinal, o fechamento político era uma necessidade circunstancial e temporária frente à "ameaça comunista”, e o crescimento das desigualdades sociais era um requisito obrigatório para a acumulação capitalista e para o próprio crescimento econômico, mas que poderia vir a ser reduzida num futuro próximo ("fazer o bolo crescer, para depois dividi-lo”). É evidente que Cardoso e Faletto não comungavam com essas idéias, embora tal pudesse ter sido uma interpretação mais apressada de suas conclusões $^{150}$. Nos anos seguintes à publicação de Dependência e Desenvolvimento, Fernando Henrique Cardoso e seus colaboradores no âmbito do Cebrap tratariam de explicitar a necessidade de se restaurar a democracia, de fortalecer a sociedade civil e de se implantar medidas que promovessem a justiça social. Não restam dúvidas, portanto, que o objetivo político primordial inerente a esta versão da teoria da dependência era o combate ao regime militar e ao estilo de desenvolvimento autoritário e concentrador de renda prevalecente no Brasil e em muitos outros países latino-americanos. No entanto, diferentemente da versão ortodoxa da dependência, que via no socialismo a resposta para a superação de todos os males periféricos, as análises deste vertente não lograram explicitar, exceto talvez como fórmulas verbais genéricas (desenvolvimento em prol do povo, fortalecimento da sociedade civil, aumento da participação popular etc.), uma proposta alternativa e inequívoca de desenvolvimento econômico ${ }^{151}$. Certamente que os

\footnotetext{
${ }^{148}$ Idem, Ibidem, 183

${ }^{149}$ Idem, Ibidem, 183.

${ }^{150}$ Cardoso relata que essa fora, por exemplo, a impressão inicial de Octavio Ianni: “Quando eu disse isso [que havia crescimento econômico e diferenciação social] num seminário no México, o Octávio Ianni quase me matou: achou que eu estava aderindo ao regime militar. Eu não estava aderindo a nada: estava dizendo que havia crescimento, embora me repugnassem as formas políticas autoritárias”. Entrevista de Fernando Henrique Cardoso em MONTERO, Paula; MOURA, Flávio (orgs.), op. cit., p.31.

${ }^{151}$ O próprio Fernando Henrique Cardoso, alguns anos mais tarde, admitiria essa lacuna (em sua versão) da teoria da dependência: "Se os cepalinos são insuficientes na caracterização e na crítica, os dependentistas tornam-se, pelo muito amor a uma visão racional e integrada a partir da experiência do passado europeu, surpreendentemente estéreis: proclamam o que não deve ser, mas param a meio do
} 
sociólogos não consideravam a dependência uma característica etéria e permanente de países de formação capitalista tardia (não teria sido precisamente a intenção de se negar essa concepção estática e a-histórica sobre o fenômeno da dependência, um dos objetivos principais do ensaio dos autores?), entretanto, ao não terem demonstrado as vias através das quais se poderia alcançar “um outro desenvolvimento”, dá-se razão aos críticos que vêem na obra dos autores um certo fatalismo: uma vez que não há nas regiões periféricas forças sociais capazes de se contrapor às forças e grupos hegemônicos estrangeiros, nem há tampouco um adequado volume de formação de capital necessário aos vultuosos investimentos tecnológicos requeridos pelos setores de ponta da moderna economia industrial, apenas um desenvolvimento dependente e associado seria possível.

Em suas próximas obras sobre a dependência, Fernando Henrique confirmaria, ampliaria e modificaria alguns pontos de vista (por exemplo, a de que regimes autoritários seriam formas políticas necessárias nessa nova etapa da dependência), mas no essencial, chegaria às mesmas conclusões sobre o desenvolvimento capitalista em sociedades dependentes. Sem embargo, mais do que a análise e crítica do capitalismo periférico em si, boa parte dos esforços do autor em seus próximos estudos sobre o tema, será o de reafirmar a perspectiva metodológica desenvolvida em Dependência e Desenvolvimento frente às análises da versão ortodoxa da dependência. Se até o final dos anos 1960, a maior parte das críticas do autor repousava sobre as interpretações do PCB, do ISEB e da CEPAL - além, é claro, das interpretações funcionalistas -, dos anos 1970 em diante, sua atenção voltar-se-ia preferencialmente sobre as análises da versão ortodoxa da dependência que, mutatis mutandis, cometeriam equívocos teóricos de natureza semelhante ao pensamento gestado nas citadas instituições. Com efeito, repetidas vezes o autor defenderá que, para ter alguma validade heurística e analítica, a teoria da dependência não deveria basear-se numa tentativa de se construir abstratas e ahistóricas leis do desenvolvimento-dependente, que iam buscar na dinâmica do sistema capitalista mundial a determinação da sorte (ou azar) dos países periféricos, e sim num esforço de se empreender análises concretas de situação de dependência. No capítulo

caminho da crítica concreta. Não chegam a especificar, a não ser como crença, as forças transformadoras e só colocam parcialmente o ideal a alcançar: propõem o mesmo desenvolvimento, em benefício de outras classes. Talvez tenhamos razão. Mas a verdade é que não ajustamos as ainda nossas contas com os teóricos de "um outro desenvolvimento". CARDOSO, Fernando Henrique. "O desenvolvimento na berlinda”. In: As idéias e seu lugar: ensaios sobre as teorias do desenvolvimento. Petrópolis: Vozes, 1993, p.203-204. 
seguinte veremos como se deu parte deste debate, e também se, e em que medida, a perspectiva analítica defendida pelo autor conseguiu superar as críticas que ele próprio fazia em relação a seus contendores. 


\section{A contribuição latino-americana em perspectiva: continuidades e rupturas no estudo do desenvolvimento periférico}

Vimos nos capítulos anteriores como, a partir dos anos cinqüenta do século passado, na esteira da crise do liberalismo econômico, foi se constituindo na América Latina um pensamento original sobre o processo de desenvolvimento da região e também sobre as causas, obstáculos e condições necessárias para a superação do secular estado de atraso e pobreza em que muitas das economias locais estavam mergulhadas. As análises da escola estruturalista da Cepal ajudaram, por um lado, a “desmitificar” os fundamentos da teoria econômica convencional que, com seu falso sentido de universalidade, haviam servido de embasamento teórico para a ideologia do livrecomércio, base da política econômica e comercial levado a cabo desde pelo menos o século XIX nas ex-colônias ibero-americanas, e por outro, a plantear a necessidade de se pensar a região de acordo com suas características históricas, econômicas e sociais singulares, de periferia do capitalismo mundial. Contribuindo para o "despertar de consciência” latino-americana, os diagnósticos e proposições da escola cepalina se coadunaram - e, em realidade, foram fundamentais para seu fortalecimento - com os objetivos e expectativas de amplos movimentos sociais da região, que viam na industrialização e no planejamento estatal as chaves para a modernização e para o progresso social.

Até meados daquela década, a leitura estruturalista sobre o desenvolvimento econômico da América Latina parecia corresponder razoavelmente bem às transformações em curso nessas economias que, conforme se alegava, iniciara um processo de "desenvolvimento para dentro", a partir das restrições do mercado externo na década de 1930. A modernização da estrutura produtiva, mediante a industrialização por substituição de importações, parecia estar conseguindo: a) atenuar a histórica dependência da região em relação a exportação de produtos primários que, conforme se demonstrou, possuíam uma tendência de longo prazo de desvalorização comercial em relação aos produtos manufaturados; b) incorporar importantes parcelas da população ao processo produtivo, retirando-os do setor de subsistência e, simultaneamente, contribuindo para elevar a produtividade média da economia; c) alavancar a formação de um mercado interno de proporções consideráveis, condição sine qua non para 
“endogeneizar” o desenvolvimento. Tudo levava a crer, portanto, que se estava no caminho certo rumo à superação do atraso e do subdesenvolvimento.

Entretanto, por uma série de motivos anteriormente discutidos, as mudanças começaram a tomar rumos não-previstos, ou então novos fenômenos colocaram em xeque o esquema de “desenvolvimento para dentro" proposto pela Cepal e pelos grupos nacional-desenvolvimentistas em geral. Por um lado, o processo de industrialização não chegou a atingir um ritmo suficientemente capaz de atender as enormes demandas da população por mais emprego e melhores salários, contribuindo assim para engrossar o caldo do exército de mão-de-obra de reserva e para aumentar o inchaço urbano nas grandes metrópoles latino-americanas. Por outro lado, as crescentes exigências em volume de capital necessárias para dar continuidade ao processo industrializante traziam grandes dificuldades fiscais para os governos locais, já bastante comprometidos com as políticas sociais redistributivas (ou "populistas", conforme se apregoava). A esses fatores, veio somar-se o tensionamento do quadro político regional e internacional, que faria implodir a "aliança-desenvolvimentista”, e levaria a "burguesia nacional” - ator político fundamental na concepção estruturalista para a "transferência dos centros de decisão para dentro do país" - a enxergar com bons olhos tanto uma solução mais enérgica frente à ameaça do comunismo, quanto a colaboração com o capital estrangeiro e com os grandes conglomerados internacionais, que apenas começavam a estender seus tentáculos ao mercado interno dos países periféricos.

Pois bem, o que tudo isso parecia apontar? Em primeiro lugar, evidenciava a falácia em se conceber transformações socioeconômicas, como a transição do subdesenvolvimento ao desenvolvimento, sob um ângulo exclusiva ou predominantemente econômico (o alegado “economicismo”). Havia outros elementos entre o Estado e a economia (notadamente, a estrutura de classes) que incidiam na maneira com que os benefícios da industrialização eram propagados ao conjunto da população. Metodologicamente posto, isto significava que era o modo com que os grupos sociais controlavam politicamente (isto é, por meio do Estado) o destino, o uso e a repartição do excedente econômico, que dava forma ao processo de desenvolvimento, e não simplesmente a disposição e dinâmica dos fatores de produção. E era precisamente por suas vicissitudes políticas e socioeconômicas, que a industrialização periférica não estava conduzindo a uma maior autonomia nacional, senão a uma maior dependência por capitais e conhecimentos tecnológicos provenientes dos grandes 
centros hegemônicos, principalmente os EUA. Em segundo lugar, e como conseqüência, deixava às claras que as elites nacionais latino-americanas não necessariamente objetivavam contrapor-se aos interesses das grandes potências mundiais ou das decadentes oligarquias rurais; tinham, verdadeiramente, restrições ao populismo e às agitações populares, os quais eram virtualmente prejudiciais aos seus negócios. Nesse sentido, ficava clara a relação de continuidade e complementaridade entre o imperialismo e as burguesias nativas, ou entre os interesses "externos" e “internos”. E por fim, desmistificava a noção de que a montagem de uma moderna economia industrial nos maiores países da América Latina estaria necessariamente associada a uma maior democratização político-social, ao contrário, dava mostras de caminhar lado-a-lado com o autoritarismo e com a eliminação das possibilidades de reivindicação dos trabalhadores (alguns diriam, na superexploração do trabalho). Esses fatores apontavam numa mesma direção: o caráter dependente e excludente do processo de desenvolvimento econômico da região. A intensa modernização capitalista que alguns países da região, notadamente o Brasil, vinham experimentando, não haveria de tornar-lhes sociedades mais justas, prósperas e dotadas de autodeterminação, mas sim promoveria novas formas de exclusão política e social e propiciar novos vínculos externos de dependência.

Essas e outras constatações estariam na base do discurso dependentista que ganharia força nas ciências sociais latino-americanas a partir da segunda metade dos anos 1960. Embora seus autores reconhecessem os avanços teóricos e metodológicos proporcionados pela escola estruturalista da Cepal, em especial o enfoque centroperiférico e a historicização do subdesenvolvimento, consideravam que ela havia deixado de fora uma importante dimensão analítica: a esfera da política ou a maneira pela qual as camadas sociais dominantes dos países dependentes associavam-se, de maneira subalterna, aos desígnios do capital internacional, ensejando todo o tipo de fenômeno característico do desenvolvimento capitalista periférico (autoritarismo, concentração de renda, exclusão social, dependência cultural e tecnológica etc.). As análises da dependência buscavam, assim, ir mais longe no entendimento do processo histórico da América Latina, pretendendo acentuar não apenas os determinantes históricos e geográficos de sua situação econômica, como também ou principalmente os determinantes políticos e sociais implicados nesta situação. Ou em outros termos, pretendiam demonstrar que a condição “periférica” pressupunha não apenas a divisão 
internacional do trabalho e um certo arranjo estrutural interno (heterogeneidade do aparelho produtivo, desemprego estrutural, forte concentração de renda e de terras etc.), como também um determinado arranjo de poder no interior mesmo da estrutura social periférica que, ligando a economia à política, interna e externamente, levava às situações de dependência.

Pode-se agora indagar: foram felizes nessa empreitada intelectual? Isto é, conseguiram construir um arcabouço teórica e metodologicamente mais avançado que o estruturalismo cepalino, legando às ciências sociais latino-americanas um conhecimento científico mais apurado e duradouro sobre o problema da formação capitalista em nações periféricas do sistema mundial, e não apenas um “denuncismo" do estilo perverso de desenvolvimento desses países?

Ao menos no que se refere à versão ortodoxa da teoria da dependência, acreditamos que a resposta seja negativa. Isso não significa, evidentemente, que algumas das perspectivas e contribuições teóricas desta corrente do pensamento não tenham ajudado a desfazer certas concepções equivocadas sobre a formação e o desenvolvimento econômico da América Latina - como as explicações funcionalistas e etapistas, a noção dos “resquícios feudais” etc. - ou mesmo lançado luz sobre aspectos importantes do processo de modernização capitalista da região, como por exemplo, a compreensão de que as áreas mais “isoladas” e "pré-capitalistas” do continente mantinham estreitas relações com o eixo dinâmico da economia local e mundial, contribuindo para seu desenvolvimento, assim como a idéia de que existem mecanismos compensatórios no interior da esfera de produção dos países dependentes que atenuam ou sob um outro prima, expressam - sua fragilidade econômica internacional. Não há porque se negar a originalidade e até mesmo a contemporaneidade de algumas dessas idéias $^{1}$. Entretanto, considerando-se o quadro analítico geral, a versão ortodoxa da dependência parece ter ficado muito aquém em sua tentativa de oferecer uma interpretação substancialmente mais rica sobre o problema do subdesenvolvimento. E isso não apenas por muitos de seus diagnósticos e previsões terem sido rapidamente

\footnotetext{
${ }^{1}$ Veja-se, por exemplo, o primeiro relatório da PNUD, de 1996, sobre o desenvolvimento humano no Brasil, que, sem citar Marini, superexploração do trabalho, teoria da dependência ou qualquer outro termo correlato, afirma que o país busca compensar sua falta de competitividade internacional por meio de "fatores espúrios", como a absorção de custos ambientais e o achatamento salarial, "redescobrindo" assim - se bem que sem a perspectiva catastrofista de outrora - algo vislumbrado pelo menos um quarto de século antes na literatura dependentista. Cf. PROGRAMA DAS NAÇÕES UNIDAS PARA O DESENVOLVIMENTO. Relatório do Desenvolvimento Humano Brasil 1996. Brasília: PNUD/IPEA, 1996.
} 
contrariados pelos fatos (prova mais cabal da "perda” da capacidade explicativa), como também devido a seus autores terem repetido alguns dos velhos equívocos de natureza teórica e ideológica imputados às teorias do “desenvolvimento nacional”. Apesar das reiteradas críticas dos pensadores desta versão da teoria da dependência ao pensamento "reformista” e "pequeno-burguês” da escola cepalina, em pelo menos dois aspectos suas explicações incorriam nas mesmas limitações e "fraquezas" atribuídas ao modelo analítico da referida escola, quais sejam, o determinismo econômico e, se bem que de sinal trocado, o voluntarismo político. Não obstante a legítima e necessária denúncia da exploração econômica dos centros capitalistas mundiais e das grandes corporações industriais sobre as nações periféricas ao redor do planeta, a crítica resultou progressivamente num restabelecimento do “externo” sobre o “interno”, tornando o "imperialismo" o único fator verdadeiramente relevante na análise. Assim, a preocupação teórico-metodológica em se caracterizar as diversas situações de dependência em sua “dinâmica interna” para, a partir daí, revelar as possibilidades ou "brechas" para um outro tipo de desenvolvimento, acabou se convertendo numa nova forma ideológica, em que a "lógica do capital monopolista” é introjetada mecanicamente na dinâmica histórica dos países periféricos, condicionando-a, e, simultaneamente, não deixando outra alternativa à população explorada desses países senão a idílica e sempre possível revolução socialista.

Claro estava, já àquela época, para inúmeros pesquisadores, a falta de precisão teórica e a precária fundamentação empírica de muitos das concepções desta vertente dependentista, porém um dos questionamentos mais contundentes partiu justamente dos pesquisadores ligados à versão co-irmã da teoria da dependência. Em que pese o tom áspero e algumas vezes improcedente das críticas de Fernando Henrique Cardoso e/ou seus colaboradores aos pensadores da versão ortodoxa da dependência, especialmente Theotônio dos Santos, André Gunder Frank e Ruy Mauro Marini ${ }^{2}$, os dados,

\footnotetext{
${ }^{2}$ Marini, por exemplo, queixa-se, com razão, de que Fernando Henrique Cardoso e José Serra, em suas Desventuras da Dialética (um ensaio em que a dupla combate algumas das principais teses de Marini), cometem nítidos falseamentos textuais na análise de seu Dialética da Dependência, como por exemplo: "Na pag. 28, as Desventuras citam: "assiste-se em toda a América Latina à ressurreição da velha economia primário-exportadora" (sublinhado pelos autores), remetendo a DD [Dialética da Dependência], p. 75, onde se lê: "assiste-se em toda a América Latina a ressurreição da velha economia exportadora". Na p. 41, o que se repete na p. 44 citam: "fecha-se qualquer possibilidade de estímulo ao investimento" no setor produtor de bens-salário; a frase diz: "fecha-se qualquer possibilidade de estímulo ao investimento tecnológico" no mencionado setor (DD, p.73; meus "críticos" sublinham qualquer, a palavra-chave na frase é estímulo)...”. MARINI, RUY Mauro. "As razões do neodesenvolvimentismo". In: Dialética da dependência, op. cit., p. 188-189, grifos do autor. Apesar destas injustificáveis, e muito
} 
argumentos e evidências históricas por eles trazidos parecem corroborar a idéia de que, de maneira geral, a "teoria radical da dependência” falhou em superar os equívocos acima apontados do modelo analítico estruturalista e, até por conta disso, foi incapaz de retratar adequadamente a nova dinâmica do desenvolvimento capitalista latinoamericano, que se inaugurava com a vinda maciça das empresas multinacionais para os grandes países da região. Na verdade, todo o edifício conceitual da vertente ortodoxa da teoria da dependência esteve baseado, conforme apontava Cardoso ${ }^{3}$, em cinco "teses equivocadas” sobre a dependência e o imperialismo na América Latina.

A primeira dessas teses, e talvez o eixo analítico central dessa vertente dependentista, sustenta que o desenvolvimento econômico capitalista é inviável na periferia ${ }^{4}$. Baseados em algumas constatações, em boa parte corretas, sobre a estrutura econômica e produtiva dos países periféricos (a escassez de capital, a industrialização “capital intensive”, o excedente de mão-de-obra etc.), muitos pensadores - incluindo-se aí, como vimos anteriormente, os estruturalistas - foram levados a crer que a América Latina caminhava a passos largos rumo à estagnação e ao colapso econômico. Ora, argumenta Cardoso, a existência e mesmo o agravamento de certas contradições sociais do capitalismo periférico não podem ser tomadas de forma alguma como sintomas de uma “tendência estrutural ao estancamento" (na versão mais moderada dos estruturalistas), ou de uma lei inexorável que levaria à sua total destruição (na acepção apocalíptica da versão ortodoxa da dependência), muito pelo contrário, defende ele, é uma característica intrínseca do desenvolvimento capitalista, seja ele dependente ou não, a criação e a renovação constante de todo tipo de desigualdade e exclusão social: “Toda economia capitalista e não só a periférica cresce contraditoriamente, criando problemas sociais, políticos e econômicos. Assim, por exemplo, strictu sensu, a marginalidade urbana é conseqüência de uma certa fase do desenvolvimento capitalista,

desnecessárias, adulterações, a maioria das críticas de Cardoso e Serra são, conforme veremos a seguir, procedentes.

${ }^{3}$ CARDOSO, Fernando Henrique. “As tradições do desenvolvimento-associado”. Estudos Cebrap, São Paulo, vol. 8, 1974, p.42-75

4 Vânia Bambirra e Theotônio dos Santos negam que eles ou seus pares tenham defendido a tese estagnacionista ou a idéia correlata de que era impossível haver um desenvolvimento das forças produtivas nos países periféricos. Ora, tal argumentação não apenas era repetida ad nauseam nos diversos textos da vertente ortodoxa da dependência (vide seção anterior), como na mesma página em que rejeita essa "equivocada" interpretação sobre suas idéias, Theotônio reafirma de forma contundente e inquestionável a velha crença estagnacionista (e o que é mais grave, essa afirmação fora feita em pleno ano de 1998!): “[...] o imperialismo bloqueia o desenvolvimento das forças produtivas das nações colonizadas, decepa seu poder de crescimento econômico, de desenvolvimento educacional, de saúde e outros.” SANTOS, Theotônio. Teoria da Dependência - Balanço e Perspectivas, op. cit., p. 50, grifo nosso; BAMBIRRA, Vânia. Teoria de La Dependencia - Una Anticrítica. México: Era, 1978, p. 49-50. 
em condições sociais dadas. Mas a partir dos efeitos negativos do capitalismo dependente sobre a oferta de empregos a visão catastrofista não pode ser generalizada para todos os países, nem para todas as fases dos ciclos de expansão capitalista” ${ }^{5}$. Com efeito, já a partir de meados dos anos sessenta, quando a taxa de crescimento econômico brasileira ainda patinava, e sobravam motivos para crer que não sairíamos do poço caso não fossem efetuadas as tais "reformas de base”, inúmeros estudos econômicos ${ }^{6}$, e notadamente o famoso ensaio “Além da Estagnação”, de Maria de Conceição Tavares e José Serra ${ }^{7}$, acentuavam que havia bases suficientemente sólidas para um novo ciclo de expansão econômica no país, demonstrando que a suposta estagnação estrutural ligada ao esgotamento do processo de substituição de importações era, em realidade, uma crise conjuntural de transição de um esquema de desenvolvimento superado para um novo, ancorado principalmente no consumo de bens duráveis pelas classes média e alta e no consumo que emanava do próprio sistema produtivo (ou consumo capitalista). Por conta disso, era perfeitamente possível, e o regime militar comprovaria isso à ferro e fogo, haver desenvolvimento econômico simultaneamente com arrocho salarial, desemprego elevado, concentração fundiária etc. Diante das fartas evidências teóricas e empíricas, os pensadores estruturalistas não tardariam em se desfazer de seus diagnósticos e previsões catastrofistas sobre o capitalismo periférico ${ }^{8}$ - embora tenham se tornado provavelmente ainda mais críticos sobre seu “estilo” excludente e dependente - coisa que os autores baseados na versão ortodoxa da dependência não apenas não deixariam de fazer, como estenderiam esse visão até mesmo ao capitalismo global, profetizando assim seu inevitável colapso e a aurora do socialismo mundial: “[...] o capitalismo é um regime decadente, imerso numa crise final sem salvação, enquanto o socialismo é um regime revolucionário cujas crises internas o depuram de suas limitações e acham novos horizontes de desenvolvimento e evolução"9.

A segunda tese “equivocada” arrolada por Fernando Henrique diz respeito à noção de superexploração do trabalho, desenvolvida principalmente por Ruy Mauro

\footnotetext{
${ }^{5}$ CARDOSO, Fernando Henrique, op. cit., p. 46.

6 Entre esses estudos, destacam-se: SINGER, Paul. "Ciclos de Conjuntura em Economias Subdesenvolvidas”. REVISTA CIVILIZAÇÃO BRASILEIRA, n²2, maio de 1965; CASTRO, Antônio Barros de. Sete Ensaios sobre a Economia Brasileira. Rio de Janeiro: Editora Forense, 1969; BRESSERPEREIRA, Luiz Carlos. "Dividir ou Multiplicar: A distribuição de Renda e a Recuperação da Economia Brasileira”. Revista Visão, novembro de 1970; entre outros.

${ }^{7}$ TAVARES, Maria de Conceição; SERRA, José. “Más allá del estancamiento”, op. cit., p.569-588

${ }^{8}$ Veja-se, por exemplo, FURTADO, Celso. O mito do desenvolvimento econômico. São Paulo: Círculo do Livro, 1974

${ }^{9}$ SANTOS, Theotônio dos. Imperialismo e corporações multinacionais, op. cit., p. 17.
} 
Marini. O problema neste caso não estava na descrição do fenômeno em si mesmo, ou seja, na idéia de que os capitalistas buscam ampliar a acumulação de capitais por meio do incremento da exploração dos trabalhadores (ampliando a jornada de trabalho) e/ou da diminuição dos níveis salariais; fenômeno já há muito tempo caracterizado por Marx na “fórmula” da mais-valia absoluta. O equívoco fundamental foi considerá-lo como uma "lei de bronze" ou como uma condição necessária do desenvolvimento capitalista dependente. O dinamismo da situação contemporânea de dependência, argumenta Cardoso, radicava não tanto na obtenção da mais-valia absoluta (o que não quer dizer que esta não lhe favorecesse), mas sim nos ganhos de produtividade advindos da introdução de melhorias científicas e tecnológicas ao processo de produção:

É verdade que em certas etapas (nos períodos de acumulação inicial), a extensão da jornada de trabalho joga um papel importante na acumulação. [...] Mas generalizar este raciocínio, para outras fases, quando a dinâmica da acumulação do setor mais avançado repousa na exploração clara da mais-valia relativa e no aumento da taxa de composição orgânica do capital, constitui um anacronismo. Depois de implantado um setor capitalista avançado, sua dinâmica (que pode ter-se beneficiado na fase inicial com as reservas de mão-de-obra e os bolsões de pobreza) não depende mais do desenvolvimento do subdesenvolvimento, mas, ao contrario, depende da criação real de um mercado de consumo capitalístico. Este não se com põe apenas pelos gastos dos trabalhadores, mas também pelo consumo dos capitalistas e, especialmente, das empresas, do Estado e das classes ligadas ao setor terciário. ${ }^{10}$

Quer isto dizer que a valorização do capital poderia prescindir da exploração dos trabalhadores? Evidentemente que não, posto ser este um dos fundamentos básicos do modo capitalista de produção, porém essa valorização se realizaria não por meio de uma “sobre-exploração” do trabalho, mas pelos investimentos tecnológicos que permitiriam aumentar a capacidade produtiva dos trabalhadores e/ou reduzir o custo relativo da mãode-obra. Como se sabe, essas considerações não foram originalmente feitas por Cardoso ou por outros críticos "neo-desenvolvimentistas", mas se encontram em diversas passagens do livro de cabeceira de Marini. Com efeito, quando o capitalismo industrial apenas engatinhava e as condições de trabalho por ele proporcionadas eram absolutamente degradantes e desumanas - quiçá, muito piores do que as condições verificadas em qualquer país periférico - Marx soube melhor do que ninguém reconhecer seu caráter “progressista” e enxergar os limites “físicos e morais” ao tipo de

\footnotetext{
${ }^{10}$ CARDOSO, Fernando Henrique, op. cit., 48.
} 
exploração aludido por Marini ${ }^{11}$. Não por acaso que, depois de examinar a luta dos trabalhadores ingleses pela redução da jornada de trabalho e por melhores condições de trabalho - no famoso “capítulo histórico” de O Capital -, evidenciando, com isso, os limites para a valorização do capital por essa via, Marx se detém sobre o que seria característico e específico do capitalismo - esta sim, uma verdade "lei” deste modo de produção - qual seja, a produção de mais valia-relativa, o que faz com que os capitalistas tenham que constantemente "[...] revolucionar as condições técnicas e sociais do processo de trabalho, portanto, o próprio modo de produção, a fim de aumentar a força produtiva do trabalho" ${ }^{12}$. E teria sido precisamente esta "lei”, e não uma suposta superexploração do trabalhador, um dos principais, senão o principal fator responsável pelo enorme incremento de produtividade no setor industrial durante os anos sessenta no Brasil. Ao menos esta é a conclusão que se extrai dos dados apresentados por Fernando Henrique Cardoso e Jose Serra, que mostram que, entre 1959 e 1970 a produtividade da força de trabalho industrial cresceu $75 \%$, enquanto que o número médio de horas trabalhadas por semana elevou-se menos que $5 \%{ }^{13}$. Uma vez demonstrada que a superexploração do trabalho não constitui condição necessária para o desenvolvimento periférico, caem por terra também outras errôneas premissas associadas a esta formulação, como a presunção de que os trabalhadores não consomem bens-industriais, ou a idéia de que haveria um desestímulo ao investimento tecnológico no setor de bens-de-consumo não duráveis, levando-o à estagnação ${ }^{14}$.

E o que dizer então da redução dos níveis salariais? Se efetivamente ocorrera esta compressão, sobretudo para as categorias de menor qualificação, isto não derivava exclusivamente de uma “lógica inexorável do desenvolvimento capitalista dependente”, mas era conseqüência, sobretudo, do encadeamento de diversos fatores extraeconômicos, como a conjuntura política específica daquele momento (em que o

\footnotetext{
11 “Além desse limite puramente físico [a necessidade de descanso dos trabalhadores], o prolongamento da jornada de trabalho esbarra em limites morais. O trabalhador precisa de tempo para satisfazer a necessidades espirituais e sociais, cuja extensão e número são determinados pelo nível geral da cultura. $A$ variação da jornada de trabalho se move, portanto, dentro de barreiras físicas e sociais". MARX, Karl, op. cit., p.188, grifo nosso.

${ }^{12}$ Idem, Ibidem, p. 251.

${ }^{13}$ SERRA, José; CARDOSO, Fernando Henrique. “As desventuras da dialética da dependência”. Estudos Cebrap, São Paulo, vol. 23, 1979, p. 71

${ }^{14}$ Quanto à primeira dessas afirmações, Serra e Cardoso constatam que nada menos que 1/3 das despesas das famílias de baixa renda eram gastos com produtos e serviços que não de alimentação e habitação; já em relação à suposta tendência à estagnação do setor de bens-de-consumo não duráveis, os autores trazem dados demonstrando que tanto a produtividade-média quanto o volume de produção haviam aumentado consideravelmente nos anos anteriores. Idem, Ibidem, p. 71-75.
} 
“combate ao comunismo” servia de justificava para todo o tipo de medida repressiva), a “força-bruta” e a razoável coesão ideológica dos militares, o "apoio” de grandes parcelas da população ao regime, o enfraquecimento e a dispersão imposta por este mesmo regime aos grupos políticos e sociais de contestação (sindicatos, partidos, organizações trabalhistas e estudantis etc.), a grande reserva de mão-de-obra barata existente, sobretudo no Nordeste, entre outros. Todos esses fatores obstaculizavam a luta dos trabalhadores pelo aumento ou reposição salarial, e inversamente, favoreciam os empresários a obterem amplas margens de lucro. Todavia, claro estava que, uma vez atenuado ou extinto alguns desses fatores (como, por exemplo, a "chancela" dos estratos burgueses ao autoritarismo ou a eficácia do discurso da doutrina da "Segurança Nacional”), a capacidade de mobilização e reivindicação dos trabalhadores por melhores salários seria prontamente restabelecida, como ficaria evidente a partir das greves operárias no ABC paulista no final dos anos setenta. Além disso, mesmo durante os "anos de chumbo", a política “oficial” de arrocho salarial não impediu que determinadas categorias profissionais, como a dos técnicos especializados, obtivessem ganhos salariais acima da inflação ${ }^{15}$; denotando, com isso, que a demanda e a oferta de força-de-trabalho, mais do que as medidas repressivas impostas pelo governo central, era o que determinava, “na raiz”, os níveis de remuneração dos trabalhadores.

Uma terceira problemática tese refere-se à assunção de que as burguesias periféricas deixaram, ou nunca foram capazes, de representar uma força social ativa. $\mathrm{O}$ alvo aqui seriam as interpretações como as de André Gunder Frank, que descreviam as burguesias periféricas como lumpen, incapazes de acumular por si próprias, entreguistas, ávidas ao consumismo, cegas a seu "real interesse” etc. Esse tipo de caracterização, argumenta Cardoso, teria se equivocado por tomar um processo ideológico por um processo real, isto é, por considerar que a burguesia havia deixado de exercer um papel histórico relevante no interior das nações dependentes, quando o que perdera totalmente a sua função social fora a "ideologia do desenvolvimento nacional burguês":

Os fatos demonstraram, em toda a América Latina, que o comportamento real das lideranças e do grosso do empresariado local não sustentou as teses reformistas quanto às modificações agrárias que se julgava serem necessárias para ampliar o mercado; nem sustentou a política de fortalecimento dos centros locais de decisão e transformação do estado em

\footnotetext{
${ }^{15}$ Cf. BACHA, Edmar. Hierarquia e remuneração gerencial. Brasília: UNB, 1973 apud CARDOSO, Fernando Henrique, op. cit., p. 73.
} 
instrumento de oposição à penetração econômica estrangeira. [...] Entretanto, reconhecer que as burguesias nacionais não se comportam como o ideário nacionalista-populista prescreve, não deve implicar em desconhecer que a forma adota pelo desenvolvimento-dependente beneficia as burguesias locais e promove sua expansão, à condição que elas se associem ou fiquem "enfeudadas" aos monopólios multinacionais e ao Estado. Com estas limitações, as burguesias nacionais continuam a desempenhar um papel ativo na dominação e no controle social das classes submetidas. ${ }^{16}$

Neste ponto cremos que a crítica de Cardoso é mal-direcionada. Os autores da versão ortodoxa da teoria da dependência não questionavam tanto a capacidade das burguesias periféricas em imporem seu domínio ao restante da sociedade (de que outra forma, pois, seria possível retirar direitos dos trabalhadores, reprimir as manifestações populares e favorecer a acumulação capitalista em escala ampliada?), nem sequer a sua capacidade "empresarial” em descobrir novas oportunidades de negócio e em maximizar seus lucros; tudo isso era razoavelmente patente. O que estes autores não concordavam, tal como Cardoso, era em relação à possibilidade da classe burguesa periférica em promover um desenvolvimento econômico ancorado em bases estritamente nacionais: seja porque acreditavam que havia no interior das sociedades dependentes mecanismos de “exportação” do excedente econômico, o que retiraria dos empresários a possibilidade de acumular capitais a ponto de lhes permitir trilhar uma via autônoma rumo ao crescimento econômico; seja porque consideravam que as elites periféricas possuíam uma mentalidade demasiadamente "satelitizada” para desafiar os desígnios do grande capital internacional, e buscar uma via própria para a modernização. Em todo o caso, dentro dos domínios do modo capitalista de produção, apenas um "lumpendesenvolvimento" seria possível, refletindo, desta forma, o caráter da dominação "lumpen-burguesa” sobre o conjunto da sociedade ${ }^{17}$. Note-se que, embora Fernando Henrique fosse muito mais parcimonioso na utilização de jargões de sentido polêmico e duvidoso, e desse mais ênfase às restrições estruturais internas da periferia (a dependência tecnológica e a própria debilidade social do empresariado industrial) do que nos condicionamentos da esfera da circulação (como na relação “metrópole-satélite” de Gunder Frank), sua avaliação em relação a este aspecto era fundamentalmente a mesma que a do autor germano-americano e seus asseclas:

\footnotetext{
${ }^{16}$ CARDOSO, Fernando Henrique, op. cit., p. 50.

${ }^{17}$ FRANK, Andre Gunder. Lumpen-Burguesia: Lumpen-Desenvolvimento, op. cit., p. 16.
} 
Eu não penso, entretanto, que a burguesia local, fruto de um capitalismo dependente, possa realizar uma revolução econômica no sentido forte do conceito. A sua "revolução" consiste em integrar-se ao capitalismo internacional como associada e dependente. Lutando, naturalmente, para obter o máximo de proveito possível. Mas limitada por um processo objetivo: a acumulação capitalista nas economias dependentes não se completa. Ou seja, a "carência de tecnologia própria" - tal como este processo é percebido vulgarmente - e a utilização de uma tecnologia importada [...] indicam apenas que o capitalismo dependente é capenga: não desenvolveu um setor avançado de produção de bens-de-capital. A acumulação, expansão e realização do capital do setor produtivo local requer seu complemento dinâmico e dele depende: a inserção do capitalismo internacional. ${ }^{18}$

A rigor, ambas as posições adotavam como contraponto histórico e normativo, implícita ou explicitamente, o arquétipo idealizado de "revolução burguesa" das nações pioneiras do desenvolvimento capitalista, sobretudo a França, com o que, conforme bem demonstrou Weffort, essas análises incorriam no mesmo tipo de equívoco que as “teorias convencionais do desenvolvimento" ${ }^{19}$. Mesmo admitindo-se a hipótese de que a “revolução democrático-burguesa” tenha correspondido aproximadamente ao exemplo histórico francês - e isso somente podia ser feito com um grau muito elevado de abstração, e ainda assim de maneira muito parcial, isto é, atendo-se aos fatos "trágicos" da Revolução Francesa de 1789, e não à sua caricata versão de 1848/1851 - nada autorizava a concluir que essa havia sido a “fórmula” modernizante por excelência dos demais países industrializados (como a Alemanha ou Japão, por exemplo) ou que a única maneira de se realizar as “tarefas burguesas” de transição/consolidação do sistema capitalista seria pela ação revolucionária de uma “bourgeoisie conquérante”. Conforme argumenta Weffort: "Elementos como ditadura/democracia, burguesia/aristocracia, campesinato/operariado, etc. combinaram-se das mais diversas maneiras nos processos políticos de transformação das sociedades agrárias em sociedades capitalistas industriais. Sobretudo, não é certo, na variedade destas situações históricas de transição ao capitalismo, que a burguesia tenha sido sempre o ator principal, nem a democracia a forma política predominante”20. Mais ainda, para os países de desenvolvimento retardatário (para não falar também das nações capitalistas “originárias”), o impulso

\footnotetext{
${ }^{18}$ CARDOSO, Fernando Henrique. “O modelo político brasileiro”. In: O modelo político brasileiro e outros ensaios. $5^{\mathrm{a}}$. ed. Rio de Janeiro: Editora Bertand Brasil, 1993, p. 71

${ }^{19}$ WEFFORT, Francisco, op.cit., p.15-24

${ }^{20}$ Idem, ibidem, p.17. O clássico estudo histórico-comparativo de Moore, apesar das inúmeras críticas, ainda é um bom parâmetro sobre os diferentes caminhos percorridos por países que lograram desenvolver-se que não através do "modelo clássico". Cf. MOORE, Barrington. As Origens Sociais da Ditadura e da Democracia. São Paulo: Martins Fontes, 1975
} 
para a acumulação capitalista, para a promoção do catching up, para as políticas de fomento ao progresso social, enfim, para o desenvolvimento - na acepção mais ampla da palavra - dependeu historicamente muito mais da mão-forte do Estado (no qual os regimes autoritários constituíram a regra, não a exceção), em sua capacidade de gerar receitas e direcionar os investimentos produtivos, na orientação da política cambial, monetária e fiscal, na "defesa” do mercado interno contra a concorrência estrangeira etc., do que da capacidade ou mesmo da existência de uma "burguesia nacionalmente orientada”, como o notório exemplo da Coréia do Sul anos mais tarde evidenciaria ${ }^{21}$.

A quarta formulação rejeitada por Cardoso era a tese do sub-imperialismo de Mauro Marini, que sustentava que países dependentes com uma estrutura produtiva mais avançada, como o Brasil, a fim de compensar a estreiteza de seu mercado interno, avançariam em direção a economias periféricas ainda menos desenvolvidas, por meio de associações com as empresas multinacionais. Dentre as conseqüências principais desta política expansionista para o país subimperialista estariam: um elevado índice de desemprego (dado a necessidade de produzir a preços baratos para os mercados internacionais); uma “dupla exploração do trabalhador” (pelo capital nacional e estrangeiro); a marginalização econômica da “indústria nacional”; um aumento no investimento do "setor improdutivo da indústria bélica”, a fim de absorver o crescente excedente de mão-de-obra; entre outras.

Além de inúmeros problemas de natureza propriamente teóricos (por exemplo, a noção de que os trabalhadores eram “duplamente” explorados, quando a noção marxista de exploração alude somente à esfera da produção e não à da circulação, o que tornaria impossível haver uma “dupla” exploração do trabalho), as proposições de Marini careciam, quase que absolutamente, de qualquer fundamentação empírica - o que era agravado pelo fato do autor querer transformá-las em "leis” do desenvolvimento dependente. E seria por meio desse “flanco” totalmente desguarnecido, que Fernando

\footnotetext{
21 Sobre o processo que levou ao extraordinário desenvolvimento do país sul-coreano, diz Lídia Goldenstein: "Não só os proprietários de terra eram politicamente fracos como inexistia uma burguesia local econômica e politicamente significativa. Até então o Japão havia utilizado o país como fonte de matéria-prima, impedindo o desenvolvimento da indústria. A reduzida indústria existente era controlada pelos japoneses que, quando se retiraram do país, a deixaram nas mãos do Estado. Ou seja, a eliminação da elite rural, a existência de uma burguesia fraca e ajuda americana permitiram o fortalecimento do Estado - cuja tradição interventora já vinha desde as leis coloniais japonesas -, abrindo caminho para o que Evans chama de "capitalismo burocrático" no qual "o aparato estatal é uma arena central no qual os ganhos e perdas do capital privado são decididos”. GOLDENSTEIN, Lídia. Repensando a dependência. São Paulo: Paz e Terra, 1994, p. 141, grifo nosso.
} 
Henrique Cardoso ${ }^{22}$, ou este em co-autoria com José Serra ${ }^{23}$, demonstrariam a invalidez da quase totalidade dos preceitos teóricos da noção de sub-imperialismo de Marini. Baseando-se fartamente no uso de dados secundários e estatísticas oficiais sobre a economia e o mercado de trabalho brasileiros durante os anos cinqüenta e setenta do século passado, os autores demonstram que: a) se ampliava - e substancialmente - o mercado de trabalho interno, chegando a dobrar em uma década o emprego industrial urbano; b) quem comandava a “alavancagem” das exportações manufatureiras não eram as multinacionais ou os setores tecnologicamente mais avançados, mas sim os setores tradicionais e supostamente "marginalizados" da indústria nacional, como o têxtil, o vestuário e o de calçados; c) as exportações do setor primário continuavam sendo muito mais relevantes para o saldo da balança comercial brasileira do que as vendas externas de produtos manufaturados (longe, portanto, de se constituírem como a "tábua de salvação" da economia); d) a participação das exportações manufatureiras para o produto industrial bruto, apesar do pequeno aumento, era ainda irrisória; e) e, por fim, os gastos com despesas militares estavam praticamente no mesmo patamar que antes do período ditatorial. Para Cardoso, o que explicava a expansão externa de alguns países o que, novamente, estava longe representar uma escalada "sub-imperialista" - não era o "sub-consumo" ou a "estreiteza do mercado interno", e sim a crescente internacionalização do processo produtivo mundial, que fazia aumentar a complementaridade entre as economias regionais, e também a necessidade dos Estados Nacionais em obterem divisas a fim de financiar a importação de insumos e bens-decapital. Daí porque países que dificilmente poderiam ser rotulados como “subimperialistas”, como a Argentina ou até mesmo a Colômbia, vinham apresentando naqueles anos uma política comercial externa até mais agressiva que a brasileira.

E por fim, o corolário de todas essas equivocadas teses, a idéia de que haveria tão-somente duas alternativas aos países capitalistas dependentes, a velha dicotomia "socialismo ou barbárie”, ou na expressão de Theotônio dos Santos: "socialismo ou fascismo”. Conseqüência da "lógica monstruosa do sistema”, isto é, da necessidade de sobre-explorar os trabalhadores e de se obter níveis cada vez maiores de excedente de capital a serem transferidos "gratuitamente" aos centros hegemônicos, o fascismo seria a expressão política necessária do capitalismo periférico quando este chegasse à etapa

\footnotetext{
${ }^{22}$ CARDOSO, Fernando Henrique. “As tradições do desenvolvimento-associado”, op. cit., p.57-71

${ }^{23}$ SERRA, José; CARDOSO, Fernando Henrique, op. cit., 61-67.
} 
do predomínio dos monopólios e do capital financeiro. Como as alternativas históricas a esse estado de coisas haviam provado ser inconsistentes, a única saída para os povos oprimidos da América Latina seria a revolução socialista, que poria fim à dupla exploração a que esses povos eram submetidos, e ajudaria a construir o socialismo em escala planetária.

Desnecessário sublinhar o quão maniqueísta era esta caracterização a respeito dos diferentes modos de produção: de um lado, do capitalismo periférico, têm-se o subdesenvolvimento, a estagnação econômica, a dependência financeira, política e tecnológica, a superexploração dos trabalhadores, o totalitarismo, as tendências políticas fascistóides etc.; do lado socialista, têm-se o desenvolvimento das forças produtivas, a autonomia de decisões, a justiça social, o fim da exploração entre os homens, a “democracia para o povo e a ditadura do proletariado para a burguesia” etc. O grande problema dessa visão "dualista” a respeito das alternativas políticas e econômicas às sociedades dependentes - e, diga-se de passagem, de quase toda caracterização do tipo dualista - estava na modalidade, extremamente polarizada, em que concebia os distintos lados em consideração, o que inequivocamente levava a um falseamento teórico. Em relação ao capitalismo periférico, como vimos, não apenas este estava longe de agonizar em seu leito de morte, como o regime político adotado em alguns dos países periféricos mais industrializados, ainda que fosse calcado na repressão e no "fechamento" parcial da participação política, não era equivalente ao fascismo ou ao totalitarismo clássico, sendo mais adequado caracterizá-lo, talvez, à maneira de uma "situação autoritária”24 ou de um "Estado Burocrático-Autoritário”25. É necessário sublinhar que isto não era apenas um problema de ordem nomenclatória, mas dizia respeito à própria natureza do sistema político à época vigente em países como Brasil, Argentina e Chile, que possuíam características bastante distintas da dos antigos regimes totalitários europeus. Assim, conforme explicava Cardoso:

[...] os regimes autoritários que caracterizam a fase atual do desenvolvimento-dependente (e com ele guardam ao menos afinidades eletivas...) não são mobilizadores, não organizam partidos e limitam as tendências existentes para transformar em doutrinas abertamente totalitárias as bases ideológicas sobre que se assentam. Em geral, nos primeiros momentos de

\footnotetext{
${ }^{24}$ Cf. LINZ, Juan. "The future of Authoritarian Situation of the Institutionalization of an Authoritarian Regime: The Case of Brazil”. In: STEPAN, Alfred (ed.). Authoritarian Brazil. New Haven: Yale University Press, 1973.

${ }^{25}$ Cf. O’DONNEL, Guillermo. Reflexões sobre os Estados Burocrático-Autoritários. São Paulo: Vértice, 1987.
} 
crise do Estado as tendências fascistas apresentam-se com energia (como no Chile de hoje), mas com o tempo a apatia é preferida à mobilização, a ordem estatal-militar à ordem político-partidária, o sopro de uma mentalidade autoritária frouxamente articulada às ideologias vigorosas do estatismo antidemocrático. ${ }^{26}$

Mais problemático ainda, já que não era somente um equívoco de natureza “teórica”, mas envolvia também as estratégias político-programáticas, estava na definição a respeito da idéia de socialismo. Ainda que se possa concordar, de maneira geral, com a premissa de que o sistema capitalista gere permanentemente processos de exclusão e desigualdade sociais, enseje relações de exploração econômica de umas nações sobre outras, promova um ritmo acelerado de dilapidação dos recursos naturais, e por fim, leve a crises econômicas periódicas (“anarquia da produção”), nada assegurava, sobretudo naquele contexto internacional de Guerra Fria e do "Socialismo Real”, que esses fenômenos seriam extintos após a revolução socialista. Além dos regimes socialistas de então apresentarem muitos dos problemas acima citados - com a exceção da elevada concentração de renda típica do capitalismo - em dois aspectos a opção pelo socialismo mostrava-se particularmente crítica: na questão do regime político, isto é, a ditadura do proletariado provou ser ainda mais restritiva à participação política e à legítima contestação do que a “democracia burguesia”, não raro, perseguindo e exterminando seus opositores; e na questão do imperialismo, ou seja, a hegemonia soviética dentro do bloco socialista em nada ficava a dever em relação ao seu congênere norte-americano sobre o mundo ocidental (vide, por exemplo, o fatídico episódio da Primavera de Praga). Em suma, ainda que se aceitasse essa visão voluntarista do "tudo ou nada" (ou bem se constrói o socialismo ou marcha-se em direção às trevas), não bastava defender a necessidade de uma vaga e idealista “revolução do proletariado”, era preciso distinguir de que maneira, uma vez adentrado no regime socialista, a dependência externa, o subdesenvolvimento e o "fascismo" seriam abolidos. Desconsiderar, como faziam os autores da versão ortodoxa da dependência, as contradições e os problemas concretos enfrentados pelas nações que haviam adentrado neste modo de produção, era ter uma concepção irreal sobre o socialismo e incorrer numa espécie de utopianismo: comparar os casos do mundo-real

\footnotetext{
${ }^{26}$ CARDOSO, Fernando Henrique, op. cit., p. 54
} 
do capitalismo, que eram imperfeitos, com o mundo-ideal do socialismo, que era tido como perfeito.

Poder-se-ia examinar aqui diversas outras omissões, concepções equivocadas e/ou infundadas, utilizações inadequadas dos conceitos marxistas, transformações que nunca ocorreram ou que foram na direção oposta ao previsto etc. Sem embargo, as insuficiências teórico-metodológicas da versão ortodoxa da dependência, aqui apontadas, já nos permite responder com segurança à pergunta acima formulada, isto é, de que esta corrente do pensamento político-social latino-americano não apenas foi incapaz de superar as falhas apontadas no modelo estruturalista de análise, como, em um duplo sentido, as levaram ainda mais longe. Por um lado, reproduziu a relação centro-periferia, abstraindo seus nuances e matizes históricos, numa mecanicista concepção de "chains of constellations of metropoles and satellites", chegando à conclusão extremada - e, bem da verdade, fundamentada numa interpretação equivocada da noção cepalina de “deterioração dos termos de intercâmbio"27 - de que o desenvolvimento metropolitano exige o subdesenvolvimento periférico. Desta forma, como que invertendo o ditado, jogou fora a criança e ficou com a água suja do banho: deixou de lado o ensinamento metodológico mais valioso legado pela economia política cepalina (examinar as especificidades histórico-estruturais da periferia para, por meio delas, desvendar os caminhos para o desenvolvimento) e radicalizou na determinação econômica do subdesenvolvimento, vendo uma perfeita continuidade entre os interesses centrais, tidos como uníssonos e nocivos, e os fenômenos sócio-políticos da periferia, voltando assim a caracterizar o imperialismo como uma espécie de “[...] enteléquia que condiciona apenas do exterior o processo histórico dos países dependentes” ${ }^{\text {„2 }}$. Por outro lado, elegeu de forma até mais voluntarista que o pensamento estruturalista - pois este, como vimos, era relativamente moderado nas recomendações de cunho político - os heróis e processos que conduziriam a um "verdadeiro desenvolvimento”: no lugar da “burguesia nacional”, o “proletariado”, as “grandes massas do povo”, as “populações marginalizadas do continente” etc.; em vez da revolução nacional-burguesa e da “internalização dos centros de decisão”, a revolução socialista e a socialização dos meios de produção. Ora, se as burguesias periféricas haviam demonstrado sua incapacidade histórica de enfrentar o imperialismo e de conduzir um projeto nacional e

\footnotetext{
${ }^{27}$ Cf. SERRA, José; CARDOSO, Fernando Henrique, op., cit., p. 45-53.

${ }^{28}$ CARDOSO, Fernando Henrique. "Teoria da dependência" ou análises concretas de situações de dependência?”, op. cit., p. 29
} 
autônomo de desenvolvimento, o que dizer então das camadas mais pobres e vulneráveis da sociedade, socialmente desprovidas e “duplamente” exploradas? Como conceber, no cenário político "fascista" da América Latina, que as massas desmobilizadas - e talvez até, indiferentes - teriam a força política necessária para tomar o poder das mãos dos militares, da lumpen-burguesia, do imperialismo norteamericano, da aristocracia agrária etc.? Ao contrário desta previsão, que tomava o exemplo histórico da revolução cubana como o grande modelo a ser seguido, os maiores focos de resistência ao capitalismo dependente, ao menos no Brasil, partiram não dos camponeses, dos revolucionários armados ou das massas marginalizadas, mas sim da parcela do operariado mais especializada e mais "beneficiada" pelo processo industrializante, qual seja, os trabalhadores das grandes empresas nacionais e internacionais (para não falar das diversas organizações "pequeno-burguesas" da sociedade civil, da Igreja Católica, de parte considerável da “imprensa burguesa” etc.).

Fica patente que o dogmatismo e o modelo "mecânico-formal”29 das análises da vertente ortodoxa da dependência impediram-na de superar os principais entraves por ela mesma apontada no pensamento estruturalista e propiciar, assim, um esquema analítico de maior duração e robustez para se compreender o desenvolvimento capitalista na periferia. Os eventuais ganhos científicos trazidos por esta corrente teórica foram eclipsados pelo exuberante dinamismo econômico da nova situação de dependência de alguns dos principais países da América Latina, que fez com que seus prognósticos sombrios a respeito do futuro da região se mostrassem rapidamente “datados” (embora seus autores continuassem, e alguns continuem até os dias atuais, aferrados na tese do “desenvolvimento do subdesenvolvimento”). Cabe então aqui repetirmos, para a vertente heterodoxa da teoria da dependência, a mesma pergunta feita no início deste capítulo: foi esta corrente do pensamento capaz de "aprender” com os erros e inconsistências das análises cepalinas, e, superando-os, contribuir para a construção de uma efetiva "teoria sobre o desenvolvimento capitalista em países periféricos”?

Numa primeira aproximação, poder-se-ia responder afirmativamente à pergunta. Apesar do enfoque dependentista de Cardoso e Faletto compartilhar com seus colegas da vertente ortodoxa alguns elementos considerados sem fundamento histórico (vide,

\footnotetext{
${ }^{29}$ Cf. PALMA, Gabriel, op. cit., p. 903.
} 
por exemplo, a terceira tese “equivocada” acima citada), seus prognósticos e preceitos teóricos, além de terem contribuído para superar as teorias funcional-etapistas, as formulações da "revolução nacional-burguesa” e as abordagens “estagnacionistas” sobre o desenvolvimento latino-americano, serviram também como ponto de partida ou como fonte de inspiração teórica para inúmeros pesquisadores que, durante os anos setenta do século passado, se empenharam em examinar as especificidades e contradições do capitalismo periférico, à luz mesmo de sua “dinâmica interna”, em seu processo de acelerado crescimento econômico e de constante diferenciação social. Com efeito, duas das proposições basilares contidas em Dependência e Desenvolvimento tiveram grande repercussão entre cientistas sociais latino-americanos, os quais, trazendo contribuições de suas respectivas especialidades e campos de atuação, ajudaram a ter uma compreensão mais realista e menos dogmática sobre o processo de desenvolvimento da região.

Em primeiro lugar, a idéia central, embutida no próprio título do livro, e que seria “empiricamente” validada, de que a dependência, ou a subordinação externa da América Latina, de forma alguma era incompatível com o crescimento econômico, com a aceleração da acumulação, com a ampliação e modernização das estruturas produtivas, enfim, com o desenvolvimento capitalista; se bem que um desenvolvimento condizente com as condições históricas e particulares dessas sociedades, mas ainda assim um processo de desenvolvimento. Era o que a feliz expressão “desenvolvimento dependente e associado" sintetizava, e o que muitos pesquisadores no âmbito do Cebrap, da chamada "Escola de Campinas”, da própria Cepal, e de diversos outros centros de ensino e pesquisa, procurariam explorar e se aprofundar em seus próprios estudos e pesquisas $^{30}$. Pode-se parecer trivial, nos dias de hoje, afirmar que a América Latina, e o Brasil em particular, desenvolviam-se economicamente, graças, especialmente, ao aprofundamento das relações de dependência, vale dizer, à penetração de empresas transnacionais e do capital financeiro internacional no mercado interno desses países. Entretanto, naquele período, tal proposição era relativamente inovadora no meio da esquerda intelectual brasileira e, talvez até, difícil de ser “tragada” por boa parte dela (dos egressos da escola estruturalista aos pensadores “neomarxistas”), que continuavam

\footnotetext{
30 Para uma relação da extensa e variada lista de autores que buscaram, nos diferentes campos do conhecimento, caracterizar a estrutura e a dinâmica dessa "nova situação de dependência", veja-se BRESSER-PEREIRA, Luiz Carlos. "Seis interpretações sobre o Brasil”, op. cit., p. 278-294; e também MANTEGA, Guido. Teoria da dependência revisitada: um balanço crítico, op. cit., p. 50-75
} 
a ver no imperialismo um fator de obstrução ao crescimento e à modernização econômicas do Terceiro Mundo. E foi precisamente esta equivocada concepção que o ensaio dos sociólogos ajudou a desfazer. Não se tratava, pois, de realizar uma apologia ao modelo de crescimento "em marcha forçada” em curso no Brasil e em outros países, longe disso, mas o de procurar explorar sua natureza, seu alcance, seu caráter dinâmico e contraditório, suas potencialidades e deficiências, enfim, tratava-se de examiná-lo cientificamente e sem os dogmas do passado, até para poder visualizar melhor as estratégias políticas que, quiçá, pudessem superá-lo. Nesse sentido, a versão heterodoxa da dependência contribuiu na deflagração de um importante filão teórico, que buscava não empreender uma “demonização” do capitalismo dependente, à maneira da esquerda marxista radical, nem tampouco realizar sua louvação, à maneira dos teóricos do status quo, mas sim fazer uma análise - para usar um termo bastante batido à época - dialética do desenvolvimento, que vai buscar na associação das multinacionais com o grande capital nacional e com as empresas estatais o fulcro do dinamismo econômico e das contradições sociais da "nova situação de dependência”.

Em segundo lugar, o estudo de Cardoso e Faletto, e muitos dos trabalhos seguintes do sociólogo brasileiro, proporcionou às ciências sociais latino-americanas uma abordagem metodológica mais abrangente do que o provido até então pela escola estruturalista da Cepal para enquadrar e interpretar o fenômeno do subdesenvolvimento. Embora a relativa amplitude metodológica proposta pelos autores - combinar o método dialético com o método histórico-estrutural, a fim de realizar uma "análise integrada” das distintas situações de dependência na América Latina - possa ter sido vista por alguns como um deficiência, antes do que uma virtude - o alegado holismo (substantivo e metodológico $)^{31}$ - e, mais ainda, a falta de uma definição formal sobre o conceito de dependência possa ter contribuído para a "confusão" semântica e teórica que se instaurou no pensamento social a seu respeito, não se pode diminuir a importância que muitas de suas proposições tiveram para efeitos de uma melhor caracterização sobre o processo de desenvolvimento latino-americano, até então focados mormente em seus aspectos econômicos, ou, na interpretação mais sofisticada de um autor como Celso Furtado, em seus caracteres histórico-estruturais. Nesse sentido, a grande intuição dos autores foi perceber que “[...] o desenvolvimento é em si mesmo um processo social; mesmo seus aspectos puramente econômicos deixam transparecer a trama de relações

\footnotetext{
${ }^{31}$ Cf. PACKENHAM, Robert, op. cit., p. 33-54.
} 
sociais subjacentes”32, e que para apreende-lo, portanto, não bastava, ainda que fosse necessário, uma análise "estrutural” do processo econômico, fazia-se necessário, outrossim, um exame detido da esfera que "dava vida” a este processo, isto é, sua dimensão político-social, ou em outras palavras:“[...] a relação das lutas políticas entre grupos e classes, por um lado, e a histórica das estruturas econômico-políticas de dominação, internas e externas, por outro" ${ }^{33}$. Com isso, os autores evidenciaram que para explicar o atraso econômico e social da América Latina, era preciso ir além da esfera das relações comerciais (a relação centro-periferia), ou mesmo da esfera das estruturas econômico-sociais (predomínio do setor primário, acentuado desequilíbrio externo, alta concentração de renda, desemprego estrutural etc.), era mister um análise que recuperasse o sentido e a natureza eminentemente sócio-política deste processo: o papel jogado pelo Estado, a articulação dos grupos e classes sociais, interna e externamente, a fim controlar ou direcionar o excedente econômico; a orientação valorativa dos atores; a dinâmica das estruturas de dominação etc. O significado mais profundo desta perspectiva - que não fazia senão levar às últimas conseqüências o postulado estruturalista de se pensar a América Latina de acordo com suas próprias características histórico-sociais singulares - foi a de explicitar que "a dinâmica social latino-americana é determinada, em primeira instância, por “fatores internos”, e, em última instância, por "fatores externos", a partir do momento em que se estabelece o Estado Nacional” ${ }^{34}$. Vários seriam os trabalhos que, inserindo-se nessa perspectiva “internalista” sobre o problema do subdesenvolvimento, ajudariam a compor um quadro mais completo do processo capitalista na América Latina: das análises sobre o “autoritarismo burocrático”, às pesquisas sobre a marginalidade urbana, das discussões sobre os “esquemas de acumulação", às interpretações sobre o "sistema de cultura”, e daí por diante.

Claro está, portanto, que o principal mérito da vertente heterodoxa da teoria da dependência foi ter “[...] definido a metodologia para uma análise histórica e dialética do processo de desenvolvimento e subdesenvolvimento, e, avançado em alguns aspectos de uma teoria do desenvolvimento para países da periferia capitalista, o que já foi uma contribuição decisiva para o amadurecimento das ciências sociais latino-americanas”35.

\footnotetext{
${ }^{32}$ CARDOSO, Fernando Henrique; FALETTO, Enzo, op. cit., p. 27

${ }^{33}$ Idem, Ibidem, p. 185.

${ }^{34}$ CARDOSO DE MELLO, João Manuel, op. cit., p. 25

${ }^{35}$ MANTEGA, Guido, op. cit., p. 45.
} 
Sem embargo, terá sido isso suficiente para a "superação" do método históricoestrutural de análise, e mais amplamente, para a construção de uma nova teoria, no sentido menos pretensioso do termo, sobre a modernização capitalista em nações dependentes do planeta? Lograram os esforços analíticos de Cardoso e Faletto, e os trabalhos subseqüentes do sociólogo brasileiro, terem transcendido o esquema “economicista” das interpretações dos pensadores estruturalistas e daqueles ligados à tradição ortodoxa da dependência, assinalando concretamente a estrutura e o processo do desenvolvimento capitalista periférico “em suas determinações recíprocas”? Enfim, galvanizou-se a crítica das situações de dependência numa abordagem cientificamente superior à das correntes do pensamento supracitadas, que já contemple em si um horizonte teoricamente mais fundamentado sobre as possibilidades alternativas ao “desenvolvimento dependente-associado” (se é que outras possibilidades havia)?

Colocada nestes termos, é custoso crer que a vertente heterodoxa da teoria da dependência tenha representado para os estudos do subdesenvolvimento um salto qualitativo em relação ao enfoque estruturalista da Cepal. O maior empecilho para que isto se realizasse, nem foi, segundo pensamos, o fato, já registrado por inúmeros autores, de Cardoso e Faletto terem se utilizado, e ficado "prisioneiros”, da periodização histórica cepalina: crescimento para fora, industrialização substitutiva, internacionalização do mercado interno ${ }^{36}$. No limite, poder-se-ia argumentar que os sociólogos introduziram a análise de classes numa interpretação até então presumivelmente correta sobre a história econômica da América Latina ${ }^{37}$ - o que por si só, já seria contraditório com a premissa metodológica dos sociólogos de se “[...] buscar uma perspectiva que permita vincular concretamente os componentes econômicos e os sociais do desenvolvimento na análise da atuação dos grupos sociais e não só justapô-

\footnotetext{
${ }^{36}$ Entre esses autores destacam-se FIORI, José Luis. Em busca do Dissenso Perdido: Ensaios críticos sobre a festejada crise do Estado. Rio de Janeiro: Insight, 1995, p. 10; SALLUM JR., Brasilio. "Notas sobre o surgimento da Sociologia Política em São Paulo", op.cit., p. 84; MANTEGA, Guido, op. cit., p. 45. João Manuel Cardoso de Mello, quiçá o primeiro autor a perceber esta incongruência da obra de Cardoso e Faletto, a esse respeito argumenta: "Teria sido preciso, enfim, que não se localizasse o equívoco do pensamento da CEPAL na abstração dos condicionantes sociais e políticos, internos e externos, do processo econômico, mas que pensasse até as últimas conseqüências, a História latinoamericana como a formação e desenvolvimento de um certo capitalismo. Não se podendo arrancar de uma periodização histórica correta, nem de esquema que apanhasse concretamente o movimento econômico da sociedade, a perspectiva integradora perdeu-se, em boa parte, dando a impressão de que se passou, apenas, à introdução das classes sociais no coro teórico cepalino”. CARDOSO DE MELLO, João Manuel, op. cit., p. 26.

${ }^{37}$ Com efeito, seria apenas no final dos anos sessenta e, especialmente, a partir dos anos setenta, que novas interpretações sobre a história econômica do país, e da região como um todo, colocariam em xeque a consagrada periodização histórica formulada por Celso Furtado e pela escola estruturalista.
} 
los”38. Sem embargo, admitamos, para todos os efeitos, que a interpretação estruturalista sobre o desenrolar histórico do desenvolvimento latino-americano fosse válida, e que não houvesse a necessidade de se caracterizar uma nova periodização da histórica econômica da região, como formação e desenvolvimento de um certo capitalismo. Mesmo que fosse este o caso - o que de toda forma os autores teriam que demonstrar e não simplesmente aceitar acriticamente como o fizeram - a análise de Cardoso e Faletto não consegue, ao nosso juízo, escapar da principal limitação metodológica que eles próprios diagnosticavam no pensamento estruturalista, qual seja, a determinação econômica dos fenômenos sociais e políticos, o que lhes impediu, ademais, de conceber uma via alternativa de desenvolvimento capitalista aos países periféricos que não fosse do tipo dependente e associado.

Mais do que um simples "lapso analítico", fruto de uma incompleta crítica da economia política cepalina, esta deficiência prende-se à própria maneira com que Cardoso e Faletto interpretam o processo societal e as grandes transformações históricas na América Latina. Na verdade, muitas das limitações teórico-metodológicas apresentadas em Desenvolvimento e Dependência remontam à abordagem “dialética” que Fernando Henrique vinha se utilizando, desde pelo menos Capitalismo $e$ Escravidão no Brasil Meridional, para caracterizar a dinâmica histórica periférica. Conforme vimos anteriormente, Cardoso reiteradamente defendia em seus trabalhos que eram o "interno" e o "específico" que deveriam ser o foco privilegiado do investigador, pois era nesse nível de análise, e não na esfera nas determinações “indeterminadas” do que era geral e, portanto abstrato, que se escondia o segredo da totalidade concreta; da mesma forma que o autor postulava que eram as "determinações específicas" que explicavam, ultimamente, as transformações econômicas e político-sociais. Não obstante essa tentativa de estabelecer normativamente o "interno" como o motor dinâmico do processo histórico na periferia, em diversos momentos de suas análises, quiçá em sua maioria, não fica de modo nenhum evidente essa capacidade teórica da esfera do interno de alterar ou até mesmo contrastar os rumos dos condicionamentos gerais advindos do capitalismo central, da lógica do capital, da divisão internacional do trabalho etc.

\footnotetext{
${ }^{38}$ CARDOSO, Fernando Henrique; FALETTO, Enzo, op. cit., p.34
} 
Veja-se, por exemplo, como essa limitação aparece em cheio quando Fernando Henrique Cardoso, ainda em Capitalismo e Escravidão, trata a respeito do fim do sistema escravista no Brasil: “O caráter contraditório e dinâmico sobre o qual assenta o capitalismo escravista está dado desde sua instauração, mas ele só se apresenta como algo historicamente determinante de opções quando, através das transformações efetivas, o sistema todo começa a decompor-se. É neste momento que os movimentos sociais de negação da ordem servil tornam-se possíveis e que a consciência social apresenta suas facetas críticas ou conservadoras de forma mais pura” ${ }^{39}$. Ora, se a ação política transformadora, neste caso, a dos grupos que propugnavam a Abolição da escravatura, só consegue constituir-se como alternativa histórica viável quando o próprio sistema escravista estava em processo de degeneração, conseqüência, fundamentalmente, do fim do tráfico negreiro, então é bastante questionável a idéia de que os “fatores internos” tivessem qualquer capacidade de alterar os rumos do sistema, antes que o próprio começasse a se auto-extinguir. Neste caso, toda a rica análise do autor sobre a dinâmica e a estrutura de classes no Brasil Meridional teria sido de pouca utilidade para se entender a natureza e a extensão das transformações políticas e sociais que aí se observariam. Ao contrário, se se supõe que o término da escravidão no Brasil não estivesse condicionado apenas à decomposição econômica do sistema, e que, embora improvável, sua resolução pudesse ter sido outra, então é evidente que a possibilidade de negação da ordem servil existia muito antes de seu efetivo rompimento.

Essa mesma perspectiva "externalista” vai surgir novamente, e de forma ainda mais explícita, em Dependência e Desenvolvimento, quando Cardoso e Faletto argumentam que nas situações de dependência colonial, a história, e naturalmente a mudança, era inteiramente reflexiva às determinações metropolitanas ${ }^{40}$. É de se perguntar: não teria sido mais coerente com o enfoque dependentista perseguido no livro supor que a organização e dinâmica do sistema colonial, do sistema produtivo (plantation e/ou economia de mineração), do desbravamento e da ocupação de novos territórios, das formas de dominação político-social, e principalmente, do próprio processo de independência política (ao menos na América Espanhola), tudo isso era efetivamente estruturado a partir dos tais fatores internos, sem o que, não se explicava nem a manutenção do sistema colonial, nem tampouco sua implosão. Se é certo que na

\footnotetext{
${ }^{39}$ CARDOSO, Fernando Henrique. Capitalismo e Escravidão no Brasil Meridional, p. 19, grifo nosso.

${ }^{40}$ CARDOSO, Fernando Henrique; FALETTO, Enzo, op. cit., p.43-44
} 
situação de dependência colonial há uma dependência política formal em relação aos centros metropolitanos, não é menos verdadeiro que, também nesta configuração histórico-estrutural, a dominação externa necessite de legitimação interna, isto é, precise da intermediação de uma série de grupos locais, os quais, obtendo, direta ou indiretamente, lucros e vantagens econômicas com o comércio exterior, cumprem organizar política e militarmente uma forma de dominação que lhes é característica.

Sem embargo, poder-se-ia alegar, com razão inclusive, de que o foco do estudo dos sociólogos eram as situações de dependência que surgem após o processo de independência política, isto é, a partir do momento de fundação, ou pelo menos, da tentativa de fundação dos Estados Nacionais na América Latina. Pois bem, também aí, o excessivo peso dados aos fatores externos e gerais, sobretudo os de natureza econômica, acaba por sufocar o componente político e social do processo de desenvolvimento. Com efeito, é precisamente na análise da etapa denominada pelos autores de "internacionalização do mercado interno" que as limitações a que vimos nos referindo se mostram mais presentes.

Antes de mais nada, convém registrar que boa parte dos esforços analíticos dos autores se fazia justamente no sentido de tentar demonstrar que a nova situação de dependência em que ingressavam algumas das nações latino-americanas, radicava tanto na reordenação do sistema econômico mundial, quanto na reestruturação das relações internas de poder desses países. Assim, no exemplo histórico onde essa nova "fase” do desenvolvimento se mostrava mais claramente, isto é, o Brasil, a crise do esquema populista de dominação, e sua substituição por uma nova aliança de poder, é apontada como sendo um fator decisivo para engatilhar as modificações econômicas e estruturais que aí se observariam. Entretanto, ao examinarmos os motivos que, segundo Cardoso e Faletto, teriam levado ao esgotamento do "pacto populista”, não se encontrará motivos para crer numa suposta "autonomia relativa” da esfera da política, conforme tantas vezes preconizado pelos autores, ao contrário. Por trás desse evento de natureza “eminentemente” política, verificar-se-á que são processos de caráter econômicos e globais que vão decretar, de maneira mecânica e automática, seu término, e, simultaneamente, determinar a instauração de uma nova forma de ordenação política da sociedade, que corresponda funcionalmente à esses desígnios econômicos. Assim é que a queda do preço de exportação do café, definida, como se sabe, pelo mercado 
internacional $^{41}$, e, sobretudo, o fim da fase de “substituição fácil de importações”, ou, vista sob um outro ângulo, o início do processo de montagem da moderna economia industrial, são vistos como fatores que, mais do que favorecem, determinam a instauração de uma nova aliança de poder:

[...] a "internacionalização do mercado interno" [...] ocorre quando nas economias periféricas se organiza a produção industrial dos setores dinâmicos da moderna economia, basicamente as indústrias químicas, eletrônicas e automotrizes, e quando se reorganiza a antiga produção industrial a partir das novas técnicas produtivas. Essa revolução industrial de novo tipo conduz a uma reorganização administrativa, tecnológica e financeira que implica a reordenação das formas de controle social e político. ${ }^{42}$

Desta maneira, ainda que Cardoso e Faletto insistissem na idéia da "natureza política dos processos de transformação econômica”, o que se vê na análise dos autores é justamente o contrário, isto é, uma pura determinação econômica dos fenômenos macro-político e político-institucionais: a modificação na forma de organização e de funcionamento do sistema produtivo (ou no regime de acumulação) é assinalada como sendo uma condição necessária e suficiente para a alteração no sistema de alianças e nas formas de Estado, reduzindo-os assim a meros canais de reprodução da ordem econômico-social dominante:

O esquema político de sustentação dessa nova forma de desenvolvimento - no qual se articulam a economia do setor público, as empresas monopolistas internacionais e o setor capitalista moderno da economia nacional - requer que se consiga estruturar um adequado sistema de relações entre os grupos sociais que controlam tais setores econômicos; esse sistema necessita uma expressão política que possibilite a ação econômica dos distintos grupos que abrange. ${ }^{43}$

E é precisamente por atribuírem pouco valor heurístico aos meios através dos quais as determinações gerais da economia e da dinâmica do capital incidem na realidade social concreta, é que a análise propriamente política dos autores é pobre e, a rigor, incapaz de explicar as estratégias, coalizões e a atuação dos diferentes grupos

\footnotetext{
41 “É certo que os preços internacionais favoráveis ao café até 1953 permitiram que os setores agrários suportassem, sem prejuízos para seus níveis de renda, a política de proteção e de rápida expansão do setor interno; entretanto, até 1954, quando começa a mudar a conjuntura, a aliança varguista alcançou seus limites: parte dos setores agrários uniu-se à oposição de classe média urbana, fato que se somou à pressão não só dos grupos financeiros internos mas também internacionais”. Idem, Ibidem, p.152.

${ }_{42}^{42}$ Idem, Ibidem, p.165, grifo nosso.

${ }^{43}$ Idem, Ibidem, p.168, grifo nosso.
} 
sociais na arena política, para o que seria necessário ir além da vaga e pouco explicativa noção de que as classes ou os segmentos sociais expressam determinados interesses econômicos. Sobre isso, vale a pena aqui resgatar o registro de Brasilio Sallum Jr.:

Mesmo que a política esteja no centro de Dependência $e$ Desenvolvimento, ela é entendida de maneira bastante limitada. Primeiro, o Estado é concebido não apenas como expressão mas também como articulação e organização das relações de domínio entre classes e outros grupos enraizados na economia. Ainda que o Estado como organizador de classes, a autonomia que isso lhe confere em relação às classes não recebe qualquer justificativa teórica. Simplesmente é atribuída a determinadas "circunstâncias históricas". Além disso, mal são mencionadas no livro as regras e clivagens políticoinstitucionais que conformam a participação dos diferentes segmentos sociais na luta política. [...] Não se pode deixar de mencionar, ademais, outra limitação importante de Dependência e Desenvolvimento: é muito insuficiente e assistemática a análise que se faz aí das formas simbólicas que "soldam" cada sistema de alianças, ou mesmo, que orientem a luta dos atores coletivos. Essas formas simbólicas aparecem na forma ad hoc, como último recurso explicativo, quando os demais mostram-se insuficientes ${ }^{44}$.

Outro sinal bastante evidente da pouca ou nenhuma "autonomia relativa” que os autores conferiam à esfera da política desprende-se da afirmação - posteriormente retomada e ampliada por Guillermo O’Donnell ${ }^{45}$ e pelo próprio Fernando Henrique Cardoso $^{46}$ - de que o autoritarismo seria o regime político característico da nova situação de dependência da América Latina ${ }^{47}$. Note-se que, excetuando-se o exagero de considerar como "fascistas" os regimes políticos ditatoriais da região, a avaliação de Cardoso e Faletto sobre esse tópico era essencialmente a mesma que a de seus colegas da versão ortodoxa da dependência, qual seja, a de que a "lógica do capital monopolista” põe a necessidade de recolocar os mecanismos de acumulação num patamar mais elevado que o provido até então pelo modelo "populista”, levando assim a

\footnotetext{
${ }^{44}$ SALLUM JR., Brasilio, op. cit., p. 85

${ }^{45}$ Cf. O’DONNEL, Guillermo, op. cit.

${ }^{46}$ Cf. CARDOSO, Fernando Henrique. Autoritarismo e Democratização. 2a ${ }^{\mathrm{a}}$. ed. Rio de Janeiro: Paz e Terra, 1975.

${ }^{47}$ Em trabalhos posteriores, e no próprio Post-Scriptum das edições mais recentes de Dependência $e$ Desenvolvimento, Cardoso redefine o automatismo da relação entre a nova situação de dependência e o Estado burocrático-autoritário em termos de uma "afinidade eletiva" entre ambos. Ainda que essa ligeira redefinição sobre as relações entre o sistema político e o sistema econômico seja menos economicista que a versão anterior, ela não chega, a nosso ver, a constituir-se como uma explicação concreta sobre a vinculação da nova forma de dependência e as formas de Estado, para o que teria sido necessário demonstrar como essas "afinidades" materializam-se no curso do processo histórico. Novamente, a simples correlação entre a estrutura econômica e a forma política, não é condição suficiente para explicar as transformações que se processam nesta última. Sobre essa "redefinição", veja-se: CARDOSO, Fernando Henrique. "As tradições do desenvolvimento-associado”, op. cit., p.54; CARDOSO, Fernando Henrique; FALETTO, Enzo, op.cit., p. 212-213.
} 
uma necessária modificação na forma e nas funções do Estado, no sentido de "fecharse” politicamente, e no de ampliar seu raio de ação econômica ("Estado gerencial”). Com essa caracterização, os autores obscureceram justamente o que deveria ser o foco da análise, isto é, as determinações específicas (as alianças de classe, as circunstâncias locais, o arranjo político-institucional, as orientações valorativas dos atores coletivos etc.) por meio das quais se permite explicar a passagem de uma situação concreta, o Estado populista, para outra, o Estado burocrático-autoritário. Se tal tivesse sido a abordagem metodológica dos autores, talvez tivessem chegado à conclusão de que nem o regime político autoritário era uma exigência necessária para a "internacionalização das condições do mercado interno" (como o exemplo da “democracia restrita” mexicana bem demonstraria), e nem que esta forma de Estado obrigatoriamente favoreceria a montagem de uma moderna economia industrial (dos países da região, talvez o Brasil tenha sido o único em que o modelo burocrático-autoritário teve pleno êxito em “modernizar” o país).

Se a análise integrada de Cardoso e Faletto sobre o Estado e a política da nova situação de dependência perdeu-se, em boa medida, na tentativa dos autores de generalizarem o “Modelo Político Brasileiro" para o conjunto das nações latinoamericanas, a partir do momento em que as mesmas atingissem um determinado nível de desenvolvimento de suas estruturas produtivas internas (o que, de certa forma, não deixava de ser uma concepção “etapista” sobre o subdesenvolvimento), também na análise propriamente econômica dessa nova fase do desenvolvimento dependente, os condicionamentos abstratos e gerais acabaram por sobredeterminar (e nebular) a dinâmica real do processo histórico, o que, sintomaticamente, impediu os autores de conceberem qualquer possibilidade de um desenvolvimento autóctone na América Latina.

Em termos metodológicos, o maior problema desta visão é que ela incorre no mesmo tipo de fatalismo histórico que o próprio Fernando Henrique criticara em trabalhos anteriores ${ }^{48}$, tomando o caminho do curso concreto da História (brasileira, diga-se de passagem) como se fosse o único realmente possível. Ou em outros termos, como se o desenvolvimento dependente e associado tivesse sido uma "necessidade histórica”, e não apenas uma das possibilidades, embora talvez a mais provável, que

\footnotetext{
${ }^{48}$ Vide no capítulo 3.2 as colocações do próprio autor a respeito disso.
} 
logrou efetivar-se no lugar de outras tantas. Há que se registrar que Cardoso e Faletto chegam a enumerar uma série de alternativas político-econômicas à crise do modelo de “desenvolvimento para dentro" 49 , entretanto, argumentam eles, salvo a hipótese de uma improvável revolução socialista, todas elas seriam inconsistentes ou estariam fadadas ao mais rotundo fracasso, de modo que, dentro do modo capitalista de produção, a única possibilidade dos países dependentes da América Latina continuarem a se de desenvolverem, dado o esgotamento do processo de industrialização por substituição de importações, seria mediante a abertura de seus mercados internos ao controle externo. Ora, além dos autores terem descartado muito rapidamente cada uma das alternativas citadas a fim de se manter o "controle nacional do sistema produtivo”, de modo que não fica de todo evidente porque algumas delas não pudessem realmente ter ocorrido (p. ex., a contenção da política salarial), faltou-se discutir outras patentes possibilidades, que já àquela época se discutiam. Sobre isso, é curioso notar que, para bons conhecedores das proposições cepalinas para o desenvolvimento que eram, Cardoso e Faletto não tenham sequer mencionado a criação de um mercado comum latino-americano ou a exportação de produtos manufaturados como algumas das possíveis saídas para se contornar o esgotamento do processo substitutivo de importações - opção esta última que, como se sabe, seria a via por excelência trilhada pelos países do Sudeste Asiático.

Teria sido possível manter os centros de decisão dentro do país, baseando-se nessas ou noutras estratégias desenvolvimentistas? Provavelmente não, dado a grave crise fiscal enfrentada por muitos países da região, incluindo-se aí o Brasil - o que tornavam os empréstimos e investimentos estrangeiros quase um “mal necessário” - e a virtual inexistência nesses países de empresas competitivas no setor de bens-deconsumo duráveis (setor chave da "nova economia industrial”). Todavia, e este é o ponto decisivo, a "internacionalização do mercado interno" se deu não devido a uma necessidade histórica ou porque as alternativas eram, conforme alegavam os autores, todas “inviáveis", mas sim porque fora o resultado da escolha dos homens em circunstâncias político-sociais determinadas, nas quais mesmo eventos históricos meramente contingenciais são às vezes determinantes. Á título de exemplo: não teria sido a construção de Brasília, fruto de um “estalido” da mente de Juscelino Kubitschek, um dos principais motivos dos desequilíbrios macroeconômicos que "coincidiriam"

\footnotetext{
${ }^{49}$ CARDOSO, Fernando Henrique; FALETTO, Enzo, op. cit., p.156-157
} 
com o esgotamento do processo substitutivo de importações? ${ }^{50}$ Não se defende aqui a tese ingênua de que, não fosse a construção da capital federal no planalto central brasileiro, a industrialização do país poderia ter seguido seu "curso normal”; apenas quer se assinalar que o movimento histórico nada tinha de pré-determinado, que a abertura do mercado interno ao controle estrangeiro, e o grau em que isso se deu, não eram conseqüências iniludíveis do desenvolvimento capitalista dependente, ao contrário, eram frutos de decisões políticas, planejadas ou tomadas no calor dos acontecimentos, bem pensadas ou não, em um contexto histórico específico, em circunstâncias históricas determinadas ${ }^{51}$.

A rigor, a insuficiente caracterização de Cardoso e Faletto sobre as eventuais alternativas à "internacionalização do mercado interno" deu-se muito em função da premissa axial da análise dos autores de que o dinamismo econômico do desenvolvimento periférico dependia do ingresso ou da associação com capitais estrangeiros (poupança externa) - idéia essa, que, conforme sustenta Luiz Carlos Bresser-Pereira, carecia de fundamentação teórica e empírica ${ }^{52}$.

Por fim, talvez se possa alegar, em defesa dos autores, que o "fatalismo" do desenvolvimento dependente e associado não se devia única e exclusivamente a fatores de ordem econômica, como também ou principalmente a fatores sociais, isto é, devido à virtual inexistência no interior da periferia de burguesias ou setores dirigentes com um “projeto autônomo de Nação” a orientar suas ações, o que, de uma forma ou de outra,

\footnotetext{
${ }^{50}$ A esse respeito, Celso Furtado - que já à época ocupava uma posição de destaque no governo brasileiro - comenta: "O próprio Kubitschek contou que a idéia de construir Brasília lhe ocorreu como um "estalido", ao ser provocado em um comício por um interlocutor ocasional. [...] Tratava-se de fazer surgir do nada, em tempo recorde, a mil quilômetros dos centros do país, a infra-estrutura de apoio para a edificação de uma cidade capital, ao mesmo tempo que se construía a própria cidade. Isso, numa época em que o país começava a instalar a sua base industrial, devendo enfrentar enormes dificuldades financeiras. [...] Não se chegou a calcular o que tudo isso representava como pressão sobre os recursos disponíveis para investimento, mas não pode haver dúvida que parcela significativa da poupança líquida do país teve sua destinação abruptamente desviada para um projeto cuja relação produto/capital era zero ou negativa”. FURTADO, Celso. “A fantasia desfeita”. In: Obra Autobiográfica. Tomo II. São Paulo: Paz e Terra, 1997, p.64

${ }^{51}$ Não há como dissociar a entrada maciça de capitais na economia brasileira à própria visão e orientação políticas de Juscelino Kubitschek. Sobre isso, mais uma vez é esclarecedor o comentário de Celso Furtado: "Lucas Lopes se referia com ironia à críticas que faziam os grupos de esquerda a Kubitschek, acusando-o de não ter preocupações sociais e de tudo ceder aos grupos internacionais. Em realidade, o presidente não via diferença entre capital que contribuía para "criar" riqueza e capital especulativo. [...] Kubitschek estava convencido, com certo visionarismo, de que o Brasil é um grande país que nenhuma empresa internacional pode ameaçar. Não tinha idéia clara sobre os vínculos entre empresas, entre estas e o governo, e sobre o poder que tais vínculos podem gerar”. Idem, ibidem, p. 75

${ }^{52}$ Cf. BRESSER-PEREIRA, Luiz Carlos. "Do Iseb e da Cepal à Teoria da Dependência”, op. cit., p. 222223.
} 
conduziria a um "ordenamento supranacional” da economia. Desta maneira, a falência do "governo da burguesia nacional” no Brasil e na América Latina, podia ser atribuída, em última instância, à própria incapacidade histórico-estrutural das burguesias locais de perseguirem um projeto de capitalismo autóctone, preferindo, ao contrário, a condição segura e conformada de “sócio-menor do capitalismo ocidental”. Já mostramos anteriormente como esta caracterização prendeu-se, na realidade, a uma equivocada concepção de que somente por meio de uma autêntica "burguesia conquistadora" alcançar-se-á o pleno desenvolvimento, quando os caminhos que conduziam à civilização industrial eram múltiplos e não necessariamente pressupunham a existência desta mitológica classe. Pois bem, faltou dizer ainda que esta descrição também carregava demais nas tintas ao afirmar que as burguesias de países periféricos como o Brasil eram intrinsecamente heterônomas e sem vocação hegemônica, ou em outras palavras, que eram estruturalmente dependentes, ainda que representassem uma força social ativa no seio da sociedade local. Que nos dias atuais esta concepção soe exagerada e ligeiramente tautológica (a burguesia é dependente porque fruto de um capitalismo dependente, que por sua expressa a natureza dependente da estrutura de classes local) não chega a ser nenhuma novidade, o mais surpreendente é que, já àquela época, o próprio Fernando Henrique Cardoso relativizara esse que fora um dos pontoscentrais de sua tese de doutorado, defendida apenas alguns anos antes. Em trabalho escrito em 1967, portanto antes mesmo da publicação de Dependência e Desenvolvimento, assim argumentava Cardoso a respeito do comportamento social do empresariado industrial brasileiro:

[...] seria incorreto apelar para a falsa consciência de classe da burguesia urbano-industrial quando ela desenvolve uma "política de acomodação", nos momentos críticos em que aumenta a pressão popular e diminuem suas chances teóricas de acumulação. [...] Politicamente, nos momentos de crise, são justamente as "zonas de sombra" as mais importantes, pois delas advém a ambivalência do comportamento empresarial, não como um processo subjetivo da falsa consciência burguesa, mas, ao contrário, como um modo objetivo de expressar o relacionamento específico entre distintos setores capitalistas que tem na política de ziguezagues uma possibilidade mais segura de sobrevivência. ${ }^{53}$

Por si só, essa descrição já afastava a imagem de um segmento social caudatário e politicamente avesso à agir de maneira pró-ativa e soberana, ao contrário, indicava

\footnotetext{
${ }^{53}$ CARDOSO, Fernando Henrique. Mudanças Sociais na América Latina, op. cit., p. 165.
} 
precisamente que o empresariado industrial brasileiro adotava uma bem-pensada estratégia de atuação em um meio social gelatinoso e em constante mutação. Mais importante ainda, sinalizava para o componente eminentemente conjuntural e estratégico do “retraimento” nacional-burguês, num momento crítico da vida política do país, que fora o final dos anos cinqüenta e inicio dos sessenta. Apesar do profícuo insight, o sociólogo brasileiro, naquele mesmo trabalho e em seus trabalhos posteriores, incluindo-se aí o famoso ensaio escrito em parceria com seu colega chileno, não tiraria dele as potenciais conclusões que se permitiriam, persistindo com a tese da total e absoluta impossibilidade das burguesias de nações periféricas conceberem um projeto de desenvolvimento capitalista fundamentado em bases nacionais. Ironicamente, esta concepção se aproximava “às avessas” de um dos postulados mais veementemente criticados do pensamento estruturalista e nacional-desenvolvimentista de maneira geral. Com efeito, enquanto num caso superestimava-se a capacidade (e a vontade) dos grupos dirigentes locais de enfrentarem o imperialismo, o capital financeiro internacional e as grandes corporações multinacionais, concebendo-se uma voluntarista "revolução democrático-nacional burguesa”, noutro caso, subestimava-se essa mesma capacidade, vaticinando-se uma única e fatalista via para desenvolvimento capitalista periférico, qual seja, a do tipo dependente e associado. Tanto num como noutro caso, a análise acabava prisioneira de esquemas mais ou menos gerais e pré-concebidos de explicação, divorciando-se, assim, da realidade fluída e altamente complexa da dinâmica de classe em países de desenvolvimento capitalista retardatário, para os quais, nem a miragem de uma “burguesia nacionalista”, nem a idéia de uma maquiavélica - no mal uso do termo - e "entreguista” lumpen-burguesia, correspondiam. A classe burguesa de qualquer país, seja ele periférico ou não, se orienta de maneira variável, e não “estática”, de acordo com seus interesses estratégicos de curto, médio e longo prazos, para os quais a “pauta nacional” pode ou não ser um fator decisivo em suas decisões políticas e econômicas. Nesse sentido, concordamos com a teoria nacional-dependente de BresserPereira, que sustenta que:

A burguesia ou o empresariado nacional e a própria burocracia do Estado vivem um processo de permanente contradição entre sua tendência a se identificar com a formação do Estado nacional e a tentação de se aliar ao capitalismo dos países centrais. No século XIX, as burguesias européias e a americana eram nacionais, opondo-se ao cosmopolitismo socialista. Por isso, seu desenvolvimento podia ser nacional sem ser dependente. Já na segunda metade do século XX, diante da ameaça comunista, a aproximação das burguesias locais ao capitalismo internacional tornou-se naturalmente mais 
forte. Entretanto, a partir desse fato, não se poderia concluir que estava descartada a hipótese da construção de uma nação no Brasil e nos demais países em desenvolvimento, como fez a grande maioria dos intelectuais de esquerda brasileiros e latino-americanos a partir de 1964, ressentidos pelos golpes militares, e fascinados pela teoria - atrativa, porque de esquerda - da dependência associada. ${ }^{54}$

Para que a vertente heterodoxa da teoria da dependência tivesse avançado na direção de um entendimento mais aprofundado sobre o problema do atraso e do subdesenvolvimento periféricos, e, de fato, se constituído como um novo paradigma teórico do pensamento social latino-americano, e não apenas um ganho incremental, ainda que de indiscutível importância, em relação às interpretações então vigentes, teria sido necessário ter considerado muito mais seriamente seus próprios postulados metodológicos, que reiteradamente insistiam na idéia de que na dialética entre o interno e o externo, entre o concreto o abstrato, eram os primeiros, e não os últimos, que permitiam explicar o devenir histórico da dependência e do desenvolvimento na América Latina. Isso implicaria ter tido um olhar mais atento sobre os constrangimentos e possibilidades estruturais que surgem no próprio seio da economia e sociedade periféricas, as quais, sem deixar de ter vinculações com as engrenagens do sistema mundial, tem uma dinâmica que lhes são próprias. Nesse sentido, teria sido necessário conceber o processo histórico periférico, assim como sua dinâmica endógena de acumulação, para além do mero movimento reflexivo em relação às condições de funcionamento do mercado internacional; seria preciso discutir as diversas formas de Estado na América Latina, como mais do que um simples “comitê executivo de um pacto de dominação" ${ }^{55}$ que expressa os interesses econômicos dos setores econômicosocial dominantes; haveria que apreender e caracterizar as burguesias periféricas, e mesmo setores do operariado urbano, não somente como meros representantes internos dos “interesses estrangeiros”, como a antiNação dentro da Nação ${ }^{56}$; e assim por diante.

Ao não fazê-lo, isto é, ao reiteradamente negligenciar seus preceitos teóricos mais fundamentais, as análises desta vertente teórica acabaram por incorrer em muitos dos “equívocos” cometidos pelas interpretações estruturalistas e pelas explicações da superexploração imperialista, de modo que o que deveria ser seu ponto forte acabou se

\footnotetext{
${ }^{54}$ BRESSER-PEREIRA, Luiz Carlos, op. cit., p. 223

${ }^{55}$ CARDOSO, Fernando Henrique. Autoritarismo e Democratização, op. cit., p. 215.

${ }^{56}$ Idem. "Imperialismo e dependência na América Latina”. In: O modelo político brasileiro e outros ensaios, op. cit., p. 200.
} 
tornando seu calcanhar de Aquiles: a "autonomia relativa” da política quase sempre era uma autonomia muito relativa. O Estado, as instituições, o "sistema de dominação", as alianças de classe, as próprias situações de dependência, tudo isso tinha sua dinâmica ditada primordialmente não a partir dos próprios condicionamentos internos das sociedades dependentes, mas sim pelos determinantes abstratos do processo de acumulação e do sistema econômico global. Desta maneira, ainda que esta vertente da teoria da dependência não tenha caído na fácil tentação de considerar o sistema capitalista como um inibidor do desenvolvimento periférico - o que, conforme vimos, não era de maneira alguma uma consideração trivial naquele momento - não deixou de considerá-lo como um fator de absoluta distorção das estruturas econômico-políticosociais dessas nações, de modo que as tentativas para, “a partir de dentro” destas mesmas sociedades, superar ou até mesmo abalar os marcos da dependência econômica e do subdesenvolvimento social, foram invariavelmente taxadas como inviáveis, inconsistentes, anacrônicos etc. No limite, a leitura de Cardoso e Faletto sobre o desenvolvimento periférico introduziu novos elementos analíticos e atualizou historicamente as antigas teorias imperialistas (sobretudo o papel modernizante que o capital estrangeiro passara a ter nas economias do Terceiro Mundo a partir dos anos cinqüenta), mas permaneceu essencialmente constrangida pelo mesmo tipo de insuficiência teórica que aquelas, vale dizer, subsumir o processo histórico da periferia aos desígnios da estrutura e dinâmica do capitalismo global.

Não é de se espantar assim, que, conforme o próprio Fernando Henrique Cardoso anos mais tarde reconheceria ${ }^{57}$, as análises (de sua versão) da teoria da dependência, tenham sido surpreendentemente estéreis no desdobramento normativo de como, e a partir de quais forças transformadoras, seria possível transladar-se do desenvolvimento dependente e associado para um "outro desenvolvimento": na medida em que o sistema capitalista internacional condiciona de forma incontrastável as possibilidades e alternativas históricas dos países periféricos, não há realmente muito que se fazer, exceto, talvez, se aproveitar da melhor maneira, isto é, dentro dos limites do que estruturalmente é apenas possível, das "condições econômicas" que se apresentam dentro da relação de subordinação externa. Caberia então a pergunta final: teria o autor cuidado de realizar sua própria profecia?

\footnotetext{
${ }^{57}$ CARDOSO, Fernando Henrique Cardoso. “O desenvolvimento na berlinda”. In: As idéias e seu lugar: ensaios sobre as teorias do desenvolvimento. Petrópolis: Vozes, 1993, p.203
} 


\section{Considerações Finais}

O presente trabalho pretendeu passar em revista o debate intelectual, travado entre os anos cinqüenta e oitenta do século passado, em torno da questão do desenvolvimento econômico e social da América Latina, a partir de duas das principais construções teóricas já feitas sobre o assunto, o estruturalismo de Cepal e a teoria da dependência. Como um trabalho de histórias das idéias que é, este trabalho retratou a descoberta, redescoberta, adaptação e transformação das principais idéias que embasaram este debate. Tentou-se demonstrar que, não obstante muitas das teses, concepções e proposições teórico-normativas que compuseram o debate terem uma origem extracontinental (notadamente o marxismo e suas devidas “atualizações”, as teorias clássicas e neoclássicas do pensamento econômico, o keynesianismo e a development economics), elas não deixaram de ser inovadoras, porque adaptadas ao clima inóspito da periferia do capitalismo mundial, e adaptadas porque explicitamente críticas em relação ao padrão de desenvolvimento aí observado. Procurando entender a dinâmica do desenvolvimento capitalista periférico, que pouco ou nada condizia com os preceitos da teoria econômica convencional, e ao mesmo tempo, buscando oferecer soluções práticas que pudessem mitigar ou eliminar de uma vez por todas a pobreza, a desigualdade social, as altas taxas de desemprego, o atraso econômico e inúmeros outros problemas crônicos característicos dessas regiões, muitos cientistas sociais latino-americanos não tiveram receio em combinar aquelas dessemelhantes idéias, de aclimatá-las às condições peculiares da periferia, de utilizarem-nas para propósitos muitas vezes inusitados em relação ao seu uso original, enfim, de realizar um franco esforço de teorização autônomo a partir delas. Neste sentido, o “consumo” dessas idéias por parte desses pensadores, mais do que simplesmente dar novos usos a velhas formulações, representou uma verdadeira criação de novos ferramentais teóricos e novas categorias analíticas, que por si só, representou um dos capítulos mais importantes na história do pensamento sobre o desenvolvimento econômico do Terceiro Mundo.

Nossa jornada em torno deste debate iniciou-se com os trabalhos da Comissão Econômica para a América Latina, a Cepal, que, durante toda a década de cinqüenta, se revelou um dos mais importantes, senão o mais importante fórum de discussões sobre o 
desenvolvimento econômico da América Latina e seus problemas principais. Se beneficiando do ambiente político e intelectual internacionais do pós-guerra, de descrédito do liberalismo econômico e de crescente preocupação no mundo desenvolvido com o clamoroso estado de atraso de vastas regiões ao redor do planeta, assim como da nova conjuntura interna de poder de muitos desses países, igualmente receptiva ou simpática à propostas econômicas modernizantes, e, além disso, contando com um corpo técnico altamente especializado, multidisciplinar e multinacional, a Cepal empreendeu uma primeira visão mais sistematizada, gestada a partir da própria periferia do capitalismo, sobre a natureza, causas e condições que impediam essas regiões dar um verdadeiro salto qualitativo rumo ao desenvolvimento. Em permanente contato e intercâmbio com correntes de interpretação tão diferentes entre si, quanto o pensamento clássico e o marxismo, o enfoque histórico-estrutural da instituição, seja na versão mais “cíclica” de Raúl Prebisch, seja na versão mais "historicizante” de Celso Furtado, demonstrou de maneira categórica a falácia das teorias do comércio internacional, que, de maneira geral, sustentavam que a especialização das nações periféricas na produção de matérias-primas e alimentos demandados pelo centro industrializado, haveria de ser-lhes economicamente vantajosa (as tais, "vantagens comparativas”). Invertendo os pressupostos axiais dessas teorias, Prebisch, Furtado e seus companheiros da Cepal argumentavam que os diferentes pólos do sistema beneficiavam-se de maneira desigual do progresso tecnológico (enquanto os centros apropriavam-se integralmente de seus ganhos de produtividade, a periferia repassava parte de seus parcos ganhos às nações industrializadas), de modo que, a manter o velho esquema da divisão internacional do trabalho, apenas aumentar-se-ia o fosso civilizatório que os separava. A partir deste diagnóstico, e de toda leitura históricoestrutural sobre o idiossincrático processo de desenvolvimento capitalista periférico, mostramos também que os pensadores estruturalistas propuseram um amplo programa de reformas econômico-sociais aos países latino-americanos, cujo eixo central seria um acelerado processo de industrialização “voltado para dentro” e cujo grande timoneiro desse processo seria o Estado Nacional desses países (com o devido suporte das “burguesias nacionais” e das demais forças progressistas da sociedade). Defendiam assim que, mediante a transformação das estruturas produtiva, social, institucional e ocupacional, além é claro, de uma adequada gestão macroeconômica (pró atividade industrial), seria possível trazer para dentro dos países em questão os “centros de 
decisão", o que equivaleria, verdadeiramente, a "internalizar” e a alavancar o processo de desenvolvimento.

Nosso passo seguinte foi o de analisar o contexto de crise do pensamento estruturalista, a partir de meados dos anos sessenta do século passado, quando foi ficando cada vez mais patente suas limitações (ou equívocos) enquanto base teórica e ideológica para uma política de "modernização econômica” e de redenção social das massas. Mostramos que, na esteira do esgotamento do modelo de industrialização por substituição de importações, da deterioração das condições de vida de grandes parcelas da população e do colapso do modelo político populista-desenvolvimentista, uma nova abordagem no estudo do desenvolvimento capitalista periférico foi se gestando no meio da intelectualidade latino-americana de esquerda. Uma vez mais, tentamos demonstrar a criatividade e originalidade das principais interpretações pertencentes à assim denominada teoria da dependência. Partindo em boa medida do ferramental teórico estruturalista, os autores dependentistas procuraram propiciar um modelo de análise mais consistente e abrangente que o provido até então pela escola cepalina. Por certo, absorveram desta e das supra-citadas escolas do pensamento uma concepção "globalizante" a respeito do sistema capitalista, em que o desenvolvimento e o subdesenvolvimento eram tidos como fenômenos históricos, interdependentes e assimétricos, entretanto, com muito mais ênfase que no modelo estruturalista inicial, procuravam incorporar na análise os condicionantes políticos e sociais internos (enlaçados, naturalmente, ao sistema capitalista internacional), que levavam à reprodução e diferenciação das formas de dominação interna e formas de dependência externa. A partir desse quadro teórico-conceitual mais ou menos comum, vimos como as análises da dependência verteram-se em duas frentes principais: a versão ortodoxa, que se preocupou, fundamentalmente, em determinar as leis de acumulação e exploração intrínsecas às sociedades dependentes, bem como os mecanismos de transferência do excedente capitalista dessas às grandes metrópoles mundiais; e a versão heterodoxa, que, menos interessada nos determinantes gerais e abstratos do capitalismo periférico, procurou examinar as situações concretas e específicas de dependência, cuja diversidade no tempo e no espaço se dava em função de uma complexa teia de relações entre sistema produtivo, estrutura de dominação e relações econômicas externas.

Por fim, a partir de uma análise comparativa entre essas duas principais vertentes da teoria da dependência, foi-se possível verificar que, apesar de elas revelarem com 
mais acerto que as análises estruturalistas alguns dos elementos da nova dinâmica do desenvolvimento capitalista dependente, ambas acabaram sendo restringidas - em diferentes graus - pelo mesmo tipo de limitação teórico-metodológica atribuída ao pensamento histórico-estrutural da Cepal, ou seja, a determinação econômica dos processos político-sociais. Com isso, revelou-se haver um padrão de continuidade entre ambas as escolas do pensamento latino-americano muito maior do que o pressuposto no debate original, ou entre algumas das principais interpretações sobre o mesmo. No esquema analítico de André Gunder Frank, Ruy Mauro Marini, Theotônio dos Santos e dos pesquisadores a eles associados, a lógica do capital monopolista acabou por sobredeterminar - e atrofiar - de maneira absoluta a estrutura e a dinâmica do desenvolvimento capitalista dependente, tornando os determinantes ou leis internas do subdesenvolvimento elementos completamente funcionais e caudatários à acumulação de capitais em escala planetária (o que, a rigor, retira a capacidade teórica dos agentes sociais locais de influírem no devenir histórico periférico, salvo, naturalmente, a deflagração de uma revolução socialista). Com isso, perde-se o valor heurístico de um dos principais elementos metodológicos constitutivos da escola dependentista, vale dizer, a análise da relação de classes e da esfera da política, uma vez que bastaria examinar os condicionantes globais do sistema capitalista para determinar as conseqüências mecânicas e imperativas ocorridas no âmbito da periferia (desemprego, marginalidade social, estagnação, militarismo, fascismo, etc.). Assim, exceto talvez para se compreender aspectos da macro-dinâmica do capitalismo em escala supranacional e numa dimensão atemporal - o que, não por acaso, seria cada vez mais o foco deste tipo de análise, culminando, alguns anos depois, na teoria do sistema-mundo - a versão ortodoxa da teoria da dependência parece ter contribuído pouco para se compreender a realidade concreta dos países de desenvolvimento tardio, cuja histórica econômica e cujas transformações político-sociais vão muito além de meramente reproduzir internamente os desígnios das metrópoles ou de suas empresas. Daí porque muitas das previsões sombrias dos autores filiados à esta vertente teórica tenham rapidamente se chocado com a realidade do desenvolvimento periférico.

Por outro lado, tentamos demonstrar também que a vertente dependentista de Cardoso e Faletto conseguiu ir mais longe na análise integrada da internacionalização do mercado interno: não apenas lograram seus autores caracterizar com maior acerto as características políticas e econômicas da nova situação de dependência de países como 
Brasil, Argentina e México, como proporcionaram uma metodologia para o estudo do subdesenvolvimento, ao menos em tese, muito mais equipada que a da versão ortodoxa da teoria da dependência. Com efeito, ao pôr em relevo a variabilidade histórica e geográfica das diversas situações de dependência (diferentemente de Gunder Frank, por exemplo, que enfatizava os mesmos mecanismos abstratos e a-históricos atuando na perpetuação do subdesenvolvimento) e ao admitir, teoricamente, uma "autonomia relativa” dos fatores internos, sobretudo os de natureza política, atuando na moldagem das formas de produção e de dominação, as análises desta versão da teoria da dependência permitiram enxergar com mais propriedade as transformações históricas pelas quais passavam as principais economias latino-americanas, ao mesmo tempo em que “abriram” uma profícua veia teórica em que inúmeros cientistas sociais da região iriam se aprofundar durante os anos setenta do século passado.

Entretanto, como tentamos argumentar, também neste modelo de análise os fatores econômicos acabaram preponderando sobre os fatores políticos e sociais: o Estado, as “estruturas de dominação”, as instituições políticas, os grupos sociais dominantes, enfim, as principais dimensões endógenas do fenômeno da dependência, não obstante o empenho de seus autores em caracterizá-los em sua dinâmica própria, tiveram seus objetivos, interesses e/ou performance, mormente ditados em função das necessidades econômicas do capitalismo monopolista e das corporações multinacionais, resultando num trama social a respeito do desenvolvimento periférico pouco convincente, uma vez que inserido numa lógica em que o movimento histórico impõe-se caprichosamente “de fora pra dentro”. Não por acaso, as análises desta vertente tenham pendido para um certo fatalismo histórico, enxergando no capitalismo dependente e associado a única possibilidade realista dos países periféricos continuarem seu processo de modernização e desenvolvimento: uma vez que a integração econômica e produtiva mundial inexoravelmente avançam, e dado também que os papéis no sistema-mundo capitalista já estariam definidos de antemão (por certo, não nos moldes da velha divisão internacional do trabalho, mas ainda assim uma segmentação mundial assimétrica), seria cada vez mais improvável aos países de desenvolvimento retardatário alcançarem êxito por meio de estratégias desenvolvimentistas que objetivassem algo como uma 'via autônoma ou nacional' de crescimento econômico. Ao fim e ao cabo, para boa da crítica, estas e outras limitações colocariam esta versão da teoria da dependência numa posição muito próxima à de sua corrente mais ortodoxa: bastante justa e pertinente 
enquanto crítica social ao subdesenvolvimento, porém teoricamente frágil e ambígua (entre privilegiar a dimensão interna e externa da dependência) e ideologicamente incapaz de oferecer um projeto alternativo de desenvolvimento capitalista. Por conta de problemas dessa ordem, a teoria da dependência perderia bastante de sua força nas ciências sociais, tanto na América Latina quanto ao redor do globo, a partir do final dos anos 1970.

Com efeito, na entrada da década de oitenta inúmeros fatores de natureza política, econômica e intelectual contribuiriam para o declínio intelectual de toda esta literatura a que vimos discutindo. Em primeiro lugar, o aparente sucesso de alguns países no Leste Asiático em sobrepujar a dependência e o subdesenvolvimento, sem que estes tenham adotado muitas das medidas reformistas pregadas pelos autores estruturalistas, ou muito menos, sem que tenham abolido o sistema capitalista, conforme pregavam os pensadores dependentistas, fez cair por terra um dos aspectos centrais da argumentação desses autores. Afinal, estava revelando ser empiricamente possível àqueles países caminhar em direção ao desenvolvimento sem romper com as amarras do “imperialismo" e, além disso, praticando políticas econômicas bem ao gosto da ortodoxia convencional ${ }^{1}$. Em segundo lugar, outras questões mais prementes no contexto brasileiro e latino-americano daquele período, tais como a urgente necessidade da redemocratização, o problema crônico da inflação, a crise da dívida externa, o surgimento ou o fortalecimento de novos atores na arena política interna desses países etc., passariam a pautar e centralizar as discussões na esfera acadêmica e política, deixando os tópicos mais “estruturais”, e já um tanto quanto batidos, num segundo plano. Em terceiro lugar, a ascensão do monetarismo em âmbito mundial, convertendose, de maneira ampla e avassaladora, na corrente teórica dominante dentro da ciência econômica, tornariam “obsoletas” não apenas a macroeconomia keynesiana, como também a economia do desenvolvimento e a economia política (as quais, o estruturalismo cepalino e a teoria da dependência inequivocamente são ramos). De certa forma, voltava o pensamento econômico dominante (se é que em algum momento deixou de fazê-lo) a guiar-se por aquele falso sentido de universalidade de que falava

\footnotetext{
${ }^{1}$ Apesar das muitas evidências contrárias, o Banco Mundial atribui o milagre do crescimento econômico dos países asiáticos à adoção de medidas econômicas supostamente neoliberais. Cf. WORLD BANK. The East Asian Miracle. New York: Oxford University Press, 1993. Para uma crítica desse mesmo relatório, evidenciando a falácia da "market-friendly" orientação macroeconômica desses governos, vide RODRIK, Dani. "King Kong Meets Godzilla: The World Bank and The East Asian Miracle". In: FISHLOW, Albert et. al. (eds.), Miracle Or Design? Lessons From The East Asian Experience, Overseas Development Council, Policy Essay No. 11, Washington, DC, 1994, p.13-54.
} 
Prebisch, abstraindo os fenômenos e problemas econômicos de seu real conteúdo histórico, geográfico e político. Em quarto lugar, o desenvolvimento e a especialização das várias disciplinas das ciências sociais, aperfeiçoando métodos de investigação e proporcionando novas descobertas teóricas e empíricas, evidenciariam o equívoco ou o simplismo de muitas das formulações, hipóteses e previsões das escolas de pensamento em consideração ${ }^{2}$. Particularmente importante para a perda de relevância do tipo de produção teórica que se fazia, sobretudo entre os autores dependentistas, foi o crescente deslocamento que houve no interior das ciências sociais brasileiras entre Sociologia e Ciência Política, assim como o notável desenvolvimento desta última, conferindo enorme visibilidade à dimensão institucional e simbólica da esfera da política, e, simultaneamente, tornando patente as limitações das análises daqueles autores sobre este assunto ${ }^{3}$. A partir de então, a análise da política voltar-se-ia progressivamente para seus componentes eminentemente formais e/ou institucionais, ou aquilo que Florestan Fernandes chamava de "ritualismo político", desvencilhando-se largamente de seu contexto econômico e social (justamente o inverso do que faziam os pensadores da supracitada escola de pensamento). Com o aperfeiçoamento metodológico e com a criação de novos ferramentais teóricos para o estudo do Estado, dos processos e das instituições políticas, haveria cada vez menos espaço ao tipo de abordagem, holista e genérica, praticado pelos pensadores da escola dependentista. Nesse novo cenário intelectual, atitudes como a de Fernando Henrique Cardoso, que reiteradamente reprovava as tentativas de se "formalizar" ou, de alguma maneira, de se mensurar a noção de dependência, seriam consideras pouco científicas à luz dos cânones do mainstream acadêmico. E, por fim, a própria evolução das condições da economia mundial, levando a uma maior integração e interdependência entre as nações e, correlativamente, a uma sensível diminuição do poder e das atribuições dos Estados Nacionais, mesmo no interior do chamado mundo desenvolvido, em benefício de fóruns de governança e de regulação multilaterais, das empresas multinacionais, dos fluxos globais de capital etc., parecia relativizar a utilidade ou até mesmo a validade de

\footnotetext{
${ }^{2}$ Tome-se, por exemplo, a pedra angular da versão ortodoxa da teoria da dependência, isto é, a tese de que o desenvolvimento metropolitano provoca o subdesenvolvimento periférico, e vice-versa. Baseado em novos dados disponíveis sobre o assunto, afirma Cristóbal Kay: "Recent historical research has shown that the development of the centre countries was above all due to the internal creation, appropriation and use of the surplus and less to do with the pillage or exploitation of the peripheral countries. Thus, for example, the international trade between Europe and the Third World accounted for roughly 1 per cent and 3 per cent of Europe's gross domestic product (GDP) in 1830 and 1910 respectively". KAY, Cristóbal, op. cit., p. 205.

${ }^{3}$ Vide SALLUM, Brasilio, op. cit.
} 
conceitos e formulações outrora tidos como incontestáveis, tal como a noção de um sistema capitalista global polarizado entre países periféricos e centrais (ou, entre países dependentes e hegemônicos, na terminologia dependentista).

À título de conclusão, seriam esses e outros fatores motivos o suficiente para relegar essas idéias a uma espécie de "antiquário” do pensamento político-social latinoamericano, reservadas apenas às mentes mais nostálgicas e aos historiadores das idéias, como se restringidas a uma realidade histórica e a uma maneira de se pensar a questão do desenvolvimento em muito superadas? Não acreditamos nessa hipótese. Tanto do ponto de vista teórico-metodológico, quanto do ponto de vista político e ideológico - se é que possível fazer tal distinção, em se tratando do debate sobre o desenvolvimento da América Latina - consideramos que sobram razões para crer na contemporaneidade de muitas daquelas velhas idéias. Não somente porque elas contribuem na compreensão de nossa formação histórica - o fato de certas descrições não coincidirem mais com a realidade, não significa que elas não tenham sido válidas anteriormente - como muitos daqueles ensinamentos soam tão pertinentes atualmente quanto o foram há cerca de meio século atrás. A ascensão de novos centros econômicos mundiais (sem que a sombra das velhas potências tenha desaparecido por completo), a gradativa conversão ou reconversão do Brasil e dos países latino-americanos em economias baseadas no setor primário-exportador, o surgimento de novos focos de dependência externa (sobretudo financeira e tecnológica), assim como o fortalecimento de seus “representantes sociais” internos, e uma quase completa despolitização do tema do desenvolvimento (que deixou de levar em conta seus aspectos eminentemente estruturais, para limitar-se à sua faceta mais "social” - necessária, mas insuficiente -, dos indicadores globais de desenvolvimento humano), leva-nos a acreditar que parcela importante daquele corpo teórico poderia e deveria ser reaproveitado criticamente no debate contemporâneo sobre o desenvolvimento da América Latina. Afinal, a análise das condições, desafios e possibilidades da superação do atraso econômico, da pobreza e das enormes contradições sociais, de forma alguma eliminados nessa parte do planeta, ainda requer uma perspectiva integrada, atenta para as particularidades estruturais de cada região e de cada situação histórica, preocupada com a dinâmica social e política do processo de modernização, e informada sobre as articulações entre os determinantes específicos e universais do sistema capitalista, sem o que a interpretação e as proposições para a superação do subdesenvolvimento facilmente descambam para um 
puro formalismo abstrato - de conhecidas conseqüências para o desenvolvimento latino-americano. 


\section{BIBLIOGRAFIA}

ARNDT, H.W. Economic Development: The History of an Idea. Chicago: Chicago University Press, 1987

ARRUDA, Maria Arminda do Nascimento. “A sociologia de Florestan Fernandes”. Tempo Social, São Paulo, v. 22, nº.1, p. 9-27, 2010.

BACHA, Edmar. Hierarquia e remuneração gerencial. Brasília: UNB, 1973

BAMBIRRA, Vânia. Teoria de La Dependencia - Una Anticrítica. México: Era, 1978

BARAN, Paul. A economia política do desenvolvimento. 3a. ed. Rio de Janeiro: Zahar, 1972

BASTIDE, Roger; FERNANDES, Florestan. Brancos e negros em São Paulo. São Paulo: Global Editora, 2008.

BASTOS, Elide Rugai et al. (Org.). Conversas com sociólogos brasileiros. São Paulo: Editora 34, 2006

BIDERMAN, Ciro et al. (Org.). Conversas com economistas brasileiros. São Paulo: Editora 34, 1996

BIELSCHOWSKY, Ricardo. Pensamento econômico brasileiro: o ciclo ideológico do desenvolvimentismo. $2^{\mathrm{a}}$. ed. rev., Rio de Janeiro: Contraponto Editora, 1995

BIELSCHOWSKY, Ricardo. "Cincuenta años del pensamiento de la Cepal: una reseña”. In: CEPAL. Cincuenta años de pensamiento en la Cepal - Textos Seleccionados. Volumen I. Santiago: Fundo de Cultura Económica, p. 9-62, 1998.

BLOSTRÖM, Magnus; HETTNE, Bjorn. La teoria del desarollo en transicion. Mexico D.F: Fondo de Cultura Económica, 1990 
BRANDÃO, Gildo Marçal. A esquerda positiva: as duas almas do Partido Comunista 1920/1964. São Paulo: Editora Hucitec, 1997

BRANDÃO, Gildo Marçal. "O revolucionário da ordem: O Brasil e a América Latina em Oliveiros S. Ferreira”. Lua Nova, São Paulo, nº48, p. 127-242, 1999

BRANDÃO, Gildo Marçal. "Celso Furtado: O peregrino da ordem do desenvolvimento”. Revista República, São Paulo, p.105-109, 2002.

BRESSER-PEREIRA, Luiz Carlos. "Dividir ou Multiplicar: A distribuição de Renda e a Recuperação da Economia Brasileira”. Revista Visão, novembro de 1970

BRESSER-PEREIRA, Luiz Carlos. "Seis interpretações do Brasil”. Dados, Rio de Janeiro, 25(3), 1982

BRESSER-PEREIRA, Luiz Carlos; REGO, José Márcio (Orgs.). A grande esperança em Celso Furtado: ensaios em homenagem aos seus 80 anos. São Paulo: Editora 34, 2001

BRESSER-PEREIRA, Luiz Carlos. Desenvolvimento e Crise no Brasil. 5a. ed., São Paulo: Editora 34, 2003

BRESSER-PEREIRA, Luiz Carlos. "Do Iseb e da Cepal à Teoria da Dependência”. In: TOLEDO, Caio Navarro (Org.). Intelectuais e política no Brasil: a experiência do ISEB. São Paulo: Revan, 2005

CAMARGO, Cândido Procópio Ferreira de (Org.). São Paulo 1975: crescimento e pobreza. São Paulo: Loyola, 1976

CANDIDO, Antonio. "Entrevista”. In: Brigada Ligeira e outros escritos. São Paulo: Unesp, 1992

CARDOSO, Fernando Henrique. Mudanças Sociais na América Latina. São Paulo: Difusão Européia do Livro, 1969 
CARDOSO, Fernando Henrique. "Teoria da dependência” ou análises concretas de situações de dependência?”. Estudos Cebrap, São Paulo, vol. 1, p. 24-45, 1971

CARDOSO, Fernando Henrique. Empresário Industrial e Desenvolvimento Econômico no Brasil. 2a . ed. São Paulo: Difusão Européia do Livro, 1972

CARDOSO, Fernando Henrique. "Notas sobre o estado atual dos estudos sobre a dependência”. Cadernos Cebrap, São Paulo, vol. 11, p. 30-72, 1973

CARDOSO, Fernando Henrique. “As tradições do desenvolvimento-associado", Estudos Cebrap, São Paulo, vol. 8, p. 42-75, 1974

CARDOSO, Fernando Henrique. Autoritarismo e Democratização. 2a. ed. Rio de Janeiro: Paz e Terra, 1975

CARDOSO, Fernando Henrique. Política e Desenvolvimento em Sociedades Dependentes - Ideologias do Empresariado Industrial Argentino e Brasileiro. 2 ${ }^{\mathrm{a}}$. ed. Rio de Janeiro: Zahar Editores, 1978

CARDOSO, Fernando Henrique. As idéias e seu lugar: ensaios sobre as teorias do desenvolvimento. Petrópolis: Vozes, 1993

CARDOSO, Fernando Henrique. "O consumo da teoria da dependência nos Estados Unidos”. In: As idéias e seu lugar: ensaios sobre as teorias do desenvolvimento. Petrópolis: Vozes, 1993

CARDOSO, Fernando Henrique. “O desenvolvimento na berlinda”. In: As idéias e seu lugar: ensaios sobre as teorias do desenvolvimento. Petrópolis: Vozes, 1993

CARDOSO, Fernando Henrique. “O modelo político brasileiro”. In: O modelo político brasileiro e outros ensaios. 5a. ed. Rio de Janeiro: Editora Bertand Brasil, 1993

CARDOSO, Fernando Henrique. "Imperialismo e dependência na América Latina”. In: O modelo político brasileiro e outros ensaios. 5a. ed. Rio de Janeiro: Editora Bertand Brasil, 1993 
CARDOSO, Fernando Henrique. "Livros que inventaram o Brasil”. Novos Estudos Cebrap, São Paulo, n³7, 1993

CARDOSO, Fernando Henrique. Capitalismo e escravidão no Brasil Meridional: $O$ negro na sociedade escravocrata do Rio Grande do Sul. 5a. ed. São Paulo: Civilização Brasileira, 2003.

CARDOSO, Fernando Henrique; FALETTO, Enzo. Dependência e Desenvolvimento na América Latina: ensaio de interpretação sociológica. 9a. ed. Rio de Janeiro: Civilização Brasileira, 2010

CARDOSO, Fernando Henrique; IANNI, Octavio. Cor e Mobilidade Social em Florianópolis: aspectos das relações entre negros numa comunidade do Brasil Meridional. São Paulo: Companhia Editora Nacional, 1960

CARDOSO, Fernando Henrique; WEFFORT, Francisco Correa. (Eds.). América Latina: ensayos de interpretación sociológico-política. Santiago de Chile: Universitaria, 1970

CARDOSO DE MELLO, João Manuel. O capitalismo tardio. 11'a ed. São Paulo: Editora Unesp, 2009

CASTRO, Antônio Barros de. Sete Ensaios sobre a Economia Brasileira. Rio de Janeiro: Editora Forense, 1969

CEPAL. Cincuenta años de pensamiento en la Cepal - Textos Seleccionados. Volumen I. Santiago: Fundo de Cultura Económica, 1998.

CEPAL. Cincuenta años de pensamiento en la Cepal - Textos Seleccionados. Volumen II. Santiago: Fundo de Cultura Económica, 1998

CEPAL. "Estudio Económico de América Latina, 1949”. In: CEPAL. Cincuenta años de pensamiento en la Cepal - Textos Seleccionados. Volumen I. Santiago: Fundo de Cultura Económica, 1998. 
CEPÊDA, Vera Alves. Raízes do pensamento político de Celso Furtado: desenvolvimento, nacionalidade e Estado democrático. 1998. 236f. Dissertação (mestrado em Ciência Política) - Faculdade de Filosofia, Letras e Ciências Humanas, Universidade de São Paulo, São Paulo, 1998

CEPÊDA, Vera Alves. "O pensamento político de Celso Furtado: desenvolvimento e democracia”. In: BRESSER-PEREIRA, Luiz Carlos; REGO, José Márcio (Orgs.). A grande esperança em Celso Furtado: ensaios em homenagem aos seus 80 anos. São Paulo: Editora 34, p.167-184, 2001

CHANG, Ha-Joon. Chutando a escada - A estratégia do desenvolvimento em perspectiva histórica. São Paulo: Editora Unesp, 2003.

CHILCOTE, Ronald. Dependency and Marxism: Toward a Resolution of the Debate. London: Westview Press, 1982

CHILCOTE, Ronald. "Issues of Theory in Dependency and Marxism”. In: CHILCOTE, Ronald (ed). Latin American Perspectives, Number 1, p. 3-16, 1982

DOMINGUEZ, Jorge. "Consensus and Divergence: The State of Literature on InterAmerican Relations in the 1970s". Latin American Research Review, 13:1, p. 87-126, 1978

FERNANDES, Florestan. "Ensaio sobre o método de interpretação funcionalista em Sociologia”. Boletins da Faculdade de Filosofia, Ciências e Letras, n 170, São Paulo: Faculdade de Filosofia, Ciências e Letras, 1953

FERNANDES, Florestan. "Economia e Sociedade no Brasil: análise sociológica do subdesenvolvimento”. In: A Sociologia numa era de Revolução Social. São Paulo: Cia. Editora Nacional, 1963

FERNANDES, Florestan. A Sociologia no Brasil. 2a ed. Petrópolis: Vozes, 1980.

FERNANDES, Florestan. A integração do negro na sociedade de classes. São Paulo: Globo, 2008 
FIGUEIREDO, Argelina Cheibub. Democracia ou Reformas - Alternativas Democráticas à Crise Política 1961 a 1964. São Paulo: Paz e Terra, 1993.

FIORI, José Luis. Em busca do Dissenso Perdido: Ensaios críticos sobre a festejada crise do Estado. Rio de Janeiro: Insight, 1995

FRANK, Andre Gunder. "A Pré-Revolução de Celso Furtado. A Contra-revolução de Celso Furtado”. O Semanário, Rio de Janeiro, nº. 342, p. 18-24, julho 1963

FRANK, Andre Gunder. “A Agricultura Brasileira: Capitalismo e o Mito do Feudalismo”. Revista Brasiliense, Sao Paulo, nº 51, p. 45-70, 1964

FRANK, Andre Gunder. “Capitalist Development of Underdevelopment in Brazil”. In: Capitalism and Underdevelopment in Latin America. Harmondsworth: Penguin Books, 1969

FRANK, Andre Gunder. “Aid or exploitation”. In: Latin America: Underdevelopment or Revolution - Essays on the development of underdevelopment and the immediate enemy. New York: Modern Reader, 1969

FRANK, Andre Gunder. Capitalism and Underdevelopment in Latin America. Harmondsworth: Penguin Books, 1969

FRANK, Andre Gunder. Lumpen-Burguesia: Lumpen-Desenvolvimento. Porto: Ed. Portucalense, 1971

FRANK, Andre Gunder. "Desenvolvimento do Subdesenvolvimento LatinoAmericano”. In: PEREIRA, Luiz (Org.). Urbanização e Subdesenvolvimento, $3^{\mathrm{a}}$.ed., Rio de Janeiro: Zahar, 1976

FRANK, Andre Gunder. Acumulação dependente e subdesenvolvimento: repensando a teoria da dependência. São Paulo: Editora Brasiliense, 1980

FRANK, Andre Gunder. El desarollo del subdesarollo - Un ensayo autobiográfico. Caracas: Nueva Soceidad, 1991 
FRANK, Andre Gunder. “The Underdevelopment of Development”. In: CHEW, Sing; DENEMARK, Roberto (Orgs.). The Underdevelopment Of Development: Essays In Honour Of Andre Gunder Frank. Thousand Oaks: Sage Publications, 1996

FURTADO, Celso. Perspectivas da Economia Brasileira. Rio de Janeiro: ISEB, 1958

FURTADO, Celso. A pré-revolução brasileira. Rio de Janeiro: Fundo de Cultura, 1962

FURTADO, Celso. Desenvolvimento e Subdesenvolvimento. $2^{\mathrm{a}}$. ed. Rio de Janeiro: Fundo de Cultura, 1963

FURTADO, Celso. Dialética do Desenvolvimento. Rio de Janeiro: Fundo de Cultura, 1964

FURTADO, Celso. Subdesenvolvimento e estagnação na América Latina. Rio de Janeiro: Civilização Brasileira, 1966.

FURTADO, Celso. O mito do desenvolvimento econômico. São Paulo: Círculo do Livro, 1974

FURTADO, Celso. Formação Econômica do Brasil. 14a. ed. São Paulo: Cia. Editora Nacional, 1976.

FURTADO, Celso. “A fantasia organizada”. In: Obra Autobiográfica. Tomo I. São Paulo: Paz e Terra, 1997

FURTADO, Celso. “A fantasia desfeita”. In: Obra Autobiográfica. Tomo II. São Paulo: Paz e Terra, 1997

FURTADO, Celso. “Entre inconformismo e reformismo”. In: Obra Autobiográfica. Tomo III. São Paulo: Paz e Terra, 1997 
FURTADO, Celso. Introdução ao desenvolvimento: enfoque histórico-estrutural. $3^{\mathrm{a}}$. ed. São Paulo: Paz e Terra, 2000

FURTADO, Celso. Teoria e Política do desenvolvimento econômico. 10a . ed. São Paulo: Paz e Terra, 2000

FURTADO, Celso. A Economia Latino-Americana. 4a . ed. São Paulo: Companhia das Letras, 2007

GOERTZEL, Ted. "Lembrem-se de tudo que escrevi: O impacto de Fernando Henrique Cardoso sobre as ciências sociais”. In: D’INCAO, Maria Angela; MARTINS, Hermínio (Orgs.). Democracia, crise e reformas: estudos sobre a era Fernando Henrique Cardoso. São Paulo: Paz e Terra, 2010

GOLDENSTEIN, Lídia. Repensando a dependência. São Paulo: Paz e Terra, 1994

GUIMARÃES, Antônio Sergio. "Racial democracy”. In: SOUZA, Jessé; SINDER, Vander (Orgs.). Imagining Brazil. Lanham: Lexington Books, 2005.

HANDELMANN, Henrique. História do Brasil. Rio de Janeiro: Nacional, 1931

HIRSCHMAN, Albert. Estratégia do desenvolvimento econômico. Rio de Janeiro: Fundo de Cultura, 1961.

HIRSCHMAN, Albert. "Ideologies of economic development in Latin America”. In: A bias for hope: Essays on Development and Latin America. New Haven: Yale University Press, 1971

HIRSCHMAN, Albert. “The Rise and Decline of Development Economics”. In: Essays in Trespassing: economics to politics and beyond. Cambridge: Cambridge University Press, 1981

HOLANDA, Sérgio Buarque de. Raízes do Brasil. 26ª ed. São Paulo: Cia. das Letras, 2005 
HOSELITZ, Bert F. Sociological aspects of economic growth. Illinois: The Free Press of Glencoe, 1960.

IANNI, Octavio. As metamorfoses do escravo. São Paulo: Difel, 1962

JAGUARIBE, Hélio. Desenvolvimento Econômico e Desenvolvimento Político. Rio de Janeiro: Fundo de Cultura, 1962

KAY, Cristobal. Latin American Theories of Development and Underdevelopment. London: Routledge, 1989

LARRAIN, Jorge. Theories of Development. London: Polity Press, 1989

LEWIS, William Arthur. "O desenvolvimento econômico com oferta ilimitada de mãode-obra”. In: AGARWALA, A.N.; SINGH, S.P. (Orgs.) A economia do subdesenvolvimento. Rio de Janeiro: Forense, 1969, 406-456

LINZ, Juan. "The future of Authoritarian Situation of the Institutionalization of an Authoritarian Regime: The Case of Brazil”. In: STEPAN, Alfred (ed.). Authoritarian Brazil. New Haven: Yale University Press, 1973

LOVE, Joseph. "The Origins of Dependency Analysis". Journal of Latin American Studies and World Affairs, 22(1), 1990, p.156-157

LOVE, Joseph. A construção do Terceiro Mundo. São Paulo: Paz e Terra, 1998

LÖWY, Michael (org.). Le Marxisme em Amérique Latine de 1909 à nos Jours: Anthologie. Paris: F. Maspero, 1980

LUKÁCS, Georg. História e Consciência de Classe. São Paulo: Martins Fontes, 2003

MAIO, Marcos Chor. A História do Projeto UNESCO: Estudos Raciais e Ciências Sociais no Brasil. Rio de Janeiro: IUPERJ, 1997, tese de doutorado. 
MALLORQUIN, Carlos. Celso Furtado: um retrato intelectual. São Paulo: Xamã ; Rio de Janeiro: Contraponto, 2005

MANTEGA, Guido. A Economia Política Brasileira. 8ª ed. Petrópolis: Vozes, 1995

MANTEGA, Guido. Teoria da dependência revisitada: um balanço crítico. São Paulo: FGV-EAESP, 84 p., Relatório de Pesquisa, 1997

MARINI, Ruy Mauro. Subdesarollo y Revolución. México: Siglo Ventiuno Editores, 1969

MARINI, Ruy Mauro. "Las razones del neo-desarrollismo, respuesta a F.H. Cardoso y J. Serra”. Revista Mexicana de Sociología, México, Facultad de Ciencias Políticas y Sociales, UNAM, p. 57-106, 1978

MARINI, Ruy Mauro. Dialética da dependência. Petrópolis: Editora Vozes, 2000

MARINI, Ruy Mauro. “As razões do neodesenvolvimentismo”. In: Dialética da dependência. Petrópolis: Editora Vozes, 2000

MARTINS, Luciano. "Formação do empresariado industrial no Brasil”. Revista do Instituto de Ciências Sociais, Rio de Janeiro, vol III, nº 1 , 1966

MARX, Karl. O Capital. Vol. 1, Livro Primeiro. São Paulo: Abril Cultural, 1983

MONTERO, Paula; MOURA, Flávio (Orgs.). Retrato de Grupo - 40 Anos do Cebrap. São Paulo: Cosac Naify, 2009

MOORE, Barrington. As Origens Sociais da Ditadura e da Democracia. São Paulo: Martins Fontes, 1975

MORAES, João Quartim de. “Le statut théorique de la rélation de dépendence”, IV Seminaire Latino-Américain, CETIM, Genève, abril de 1972. Também reproduzido em 
ANDA et. al. (eds.) Dependencia y estructura de clase en America Latina. Genebra:Centre Europe-Tiers Monde, 1972.

MUÑOZ, Heraldo. "Cambio y continuidad en el debate sobre la dependencia y el imperialismo”. Revista de Estudios Internacionales, 2, nº. 44, out. dez., p. 88-138, 1978

NURSKE, Ragnar. Problemas da formação de capital em países subdesenvolvidos. Rio de Janeiro: Civilização Brasileira, 1957

O’DONNEL, Guillermo. Reflexões sobre os Estados Burocrático-Autoritários. São Paulo: Vértice, 1987

OLIVEIRA, Francisco de. "Economia Brasileira: Crítica à Razão Dualista”, Estudos Cebrap, São Paulo, vol. 2, p. 4-82, 1972

OLIVEIRA, Francisco de. "Formação econômica do Brasil: gênese, importância e influências teóricas”. In: A navegação venturosa: ensaios sobre Celso Furtado. São Paulo: Boitempo Editorial, 2003

PACKENHAM, Robert. The Dependency Movement: Scholarship and Politics in Development Studies. Cambridge, Mass.: Harvard University Press, 1992.

PALMA, Gabriel. "Dependency: A formal theory of underdevelopment or a methodology for the analysis of concrete situations of underdevelopment". World Development, $\mathrm{n}^{\circ} 6$, p. 881-924, 1978

PALMA, Gabriel. "Dependencia y desarrollo: una visión crítica”. In: SEERS, Dudley (org.). La teoría de la dependencia: una evaluación crítica. México, D.F. : Fondo de Cultura Económica, 1987

PARSONS, Talcott. The social system. Londres: Tavistock Publications, 1952.

PINTO, Anibal. "Notas sobre la distribución del ingreso y la estrategia de la redistribución”. Revista Brasileira de Ciências Sociais, Belo Horizonte, mar. 1962 
PINTO, Anibal. "Naturaleza e implicaciones de la 'heterogeneidad estructural' de la América Latina.”. In: CEPAL. Cincuenta años de pensamiento en la Cepal - Textos Seleccionados. Volumen II. Santiago: Fundo de Cultura Económica, 1998

PRADO JR. Caio Prado. A Questão Agrária. São Paulo: Editora Brasiliense, 1979.

PRADO JR. Caio Prado. Formação do Brasil Contemporâneo. São Paulo. Companhia das Letras, 2011.

PREBISCH, Raúl. "Economic Development or Monetary Stability: A False Dilemma”. Economic Bulletin for Latin America 6, n¹, mar 1961

PREBISCH, Raúl. Hacia una dinámica del desarrollo latinoamericano. México, DF: Fondo de Cultura Económica, 1963

PREBISCH, Raúl. Keynes: uma introdução. São Paulo: Brasiliense, 1991.

PREBISCH, Raúl. "El desarrollo económico de la América Latina y algunos de sus principales problemas”. In: CEPAL. Cincuenta años de pensamiento en la Cepal Textos Seleccionados. Volumen I. Santiago: Fundo de Cultura Económica, 1998.

PREBISCH, Raúl. "Hacia una nueva política comercial en pro del desarollo”. In: CEPAL. Cincuenta años de pensamiento en la Cepal - Textos Seleccionados. Volumen I. Santiago: Fondo de Cultura Económica, 1998

PROGRAMA DAS NAÇÕES UNIDAS PARA O DESENVOLVIMENTO. Relatório do Desenvolvimento Humano Brasil 1996. Brasília: PNUD/IPEA, 1996

REGO, José Marcio. “Entrevista com Enzo Faletto”. Tempo Social, São Paulo, vol.19, n.1, p. 215-221, 2007

RICARDO, David. Princípios de Economia Política e Tributação - Os Economistas. São Paulo: Abril Cultural, 1982 
RICUPERO, Bernardo. Caio Prado Jr. e a nacionalização do marxismo no Brasil. São Paulo: Editora 34, 2000

RICUPERO, Bernardo. "Celso Furtado e o pensamento social brasileiro". Estudos Avançados, São Paulo, vol. 19, nº53, p.371-377, 2005

RODRIGUEZ, Octavio. Teoria do subdesenvolvimento da Cepal. Rio de Janeiro: Forense-Universitária, 1981

RODRIK, Dani. "King Kong Meets Godzilla: The World Bank and The East Asian Miracle". In: FISHLOW, Albert et. al. (eds.), Miracle Or Design? Lessons From The East Asian Experience, Overseas Development Council, Policy Essay No. 11, Washington, DC, 1994, p.13-54

ROSENTEIN-RODAN, Paul Narcyz. "Problemas da Industrialização da Europa Oriental e Sul-Oriental”. In: AGARWALA, A.N.; SINGH, S.P (Orgs.). A economia do subdesenvolvimento. Rio de Janeiro: Forense, 1969

ROSTOW, Walt Whitman. The process of economic growth. New York: Norton, 1952.

ROSTOW, Walt Whitman. Etapas do desenvolvimento econômico: um manifesto não comunista. $2^{\mathrm{a}}$. ed. Rio de Janeiro: Zahar, 1964

ROSTOW, Walt Whitman. “A decolagem para o desenvolvimento auto-sustentado”. In: AGARWALA, A.N.; SINGH, S.P (Orgs.). A economia do subdesenvolvimento. Rio de Janeiro: Forense, 1969

SALLUM JR., Brasilio. "Notas sobre o surgimento da Sociologia Política em São Paulo". Política \& Sociedade, Florianópolis, v. 1, nº. 1, p. 73-86, 2002

SANTOS, Theotônio dos. El nuevo carácter de la dependencia, Cuaderno CESO nº10, Santiago de Chile, 1968

SANTOS, Theotônio dos. "The structure of dependence", The American Economic Review, vol. 60, n², p. 231-236, May 1970 
SANTOS, Theotônio dos. Socialismo o Fascismo: El Dilema Latinoamericano y el nuevo carácter de la dependencia. Santiago, Chile: Ed. PLA, 1972

SANTOS, Theotônio dos. "The crisis of development theory and the problems of dependence in Latin America”. In: BERNSTEIN, H. (org.). Underdevelopment and Development. Harmondsworth: Penguin Books, 1973

SANTOS, Theotônio dos. Concepto de clases sociales. Buenos Aires: Editorial Galerna: 1974

SANTOS. Theotônio dos. Imperialismo e Empresas Multinacionais. São Paulo: Paz e Terra, 1977

SANTOS, Theotônio dos. Imperialismo y Dependencia. Mexico: Ediciones Era, 1978

SANTOS, Theotônio dos. A teoria da dependência - Balanço e perspectivas. Rio de Janeiro: Civilização Brasileira, 2000

SARTRE, Jean-Paul. Questão de Método. São Paulo: Difusão Européia do Livro, 1966.

SCHWARZ, Roberto. “Um seminário de Marx”. In: Seqüências Brasileiras. São Paulo: Companhia das Letras, 1999.

SCHWARTZMAN, Simon. "As ciências sociais brasileiras no século 20”. Ciência Hoje, abr. 2000. Disponível em: <http://www.schwartzman.org.br/simon/10mais.htm>.

SEERS, Dudley. "The limitation of the special case”. Bulletin of the Oxford University Institute of Economics \& Statistics, Oxford University, vol. 25, n²2, p. 77-98, may 1963

SERRA, José; CARDOSO, Fernando Henrique. "As desventuras da dialética da dependência”. Estudos Cebrap, São Paulo, vol. 23, p. 34-80, 1979 
SINGER, Hans W. "The distribution of gains between investing and borrowing countries”. American Economic Review, vol. 40, n², American Economic Association: Menasha, p.473-485, 1949

SINGER, Paul. "Ciclos de Conjuntura em Economias Subdesenvolvidas”. REVISTA CIVILIZAÇÃO BRASILEIRA, nº2, maio de 1965

STAVENHAGEN, Rodolfo. "Sete Teses Equivocadas sobre a América Latina”. In: DURAND, João Carlos Garcia. (Org.) Sociologia de desenvolvimento. Rio de Janeiro: Zahar, 1969

SUNKEL, Osvaldo. "The development of development thinking”. The IDS Bulletin, East Sussex, volume 8, Issue 3, p. 6-12, March 1977

SUNKEL, Osvaldo. "La inflacion chilena: um enfoque heterodoxo". Cincuenta años de pensamiento en la Cepal - Textos Seleccionados. Volumen I. Santiago: Fundo de Cultura Económica, 1998

TAVARES, Maria da Conceição. "Auge y declinación del proceso de substitución de importaciones en el Brasil”. In: CEPAL. Cincuenta años de pensamiento en la Cepal Textos Seleccionados. Volunen I. Santiago de Chile: Fundo de Cultura Económica, 1998

TAVARES, Maria de Conceição; SERRA, José. “Más allá del estancamiento”. In: CEPAL. Cincuenta años de pensamiento en la Cepal - Textos Seleccionados. Volunen I. Santiago de Chile: Fundo de Cultura Económica, 1998

UNITED NATIONS. Relative Prices of Exports and Imports of Under-developed Countries: A Study of postwar terms of trade between under-developed and industrialized nations. New York, 1949

VÁSQUEZ, Juan Noyola. "Inlfación y desarollo económico en Chile y México”. In: CEPAL. Cincuenta años de pensamiento en la Cepal - Textos Seleccionados. Volunen I. Santiago de Chile: Fundo de Cultura Económica, 1998 
WEFFORT, Francisco Correa. Classes populares e política: contribuição ao estudo de populismo. 148p. Tese (doutorado em Ciência Política) - Faculdade de Filosofia, Letras e Ciências Humanas, Universidade de São Paulo, São Paulo, 1968

WEFFORT, Francisco. "Notas sobre a "teoria da dependência": teoria de classe ou ideologia nacional?”. Estudos Cebrap, São Paulo, vol. 1, p. 2-24, 1971

WORLD BANK. The East Asian Miracle. New York: Oxford University Press, 1993 